
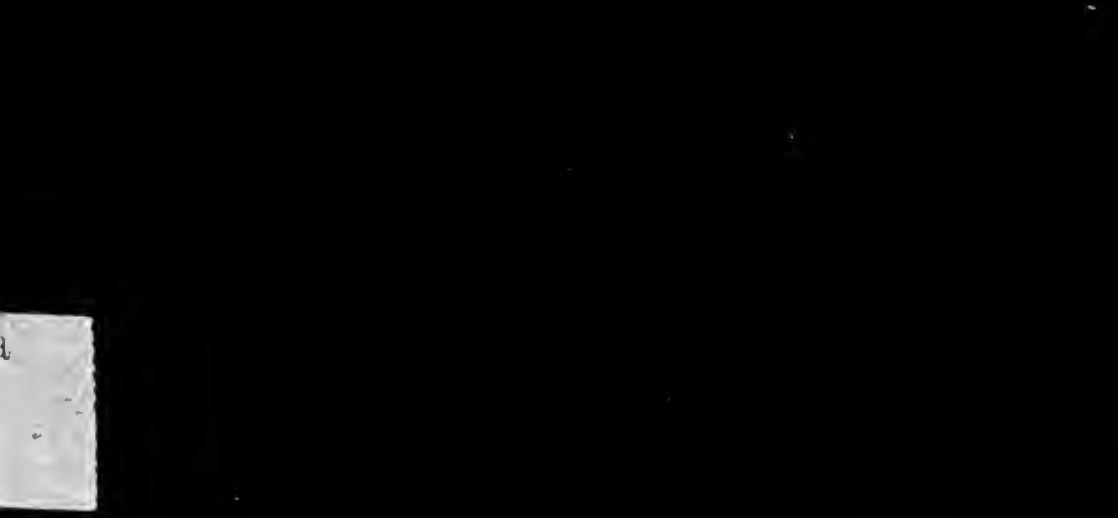


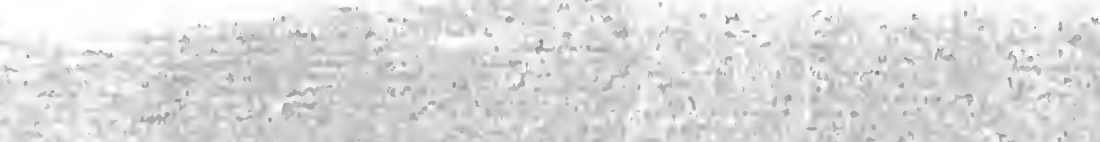

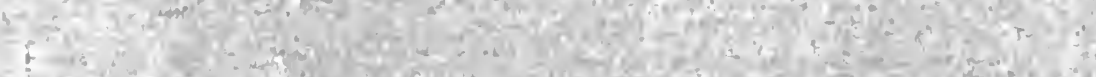

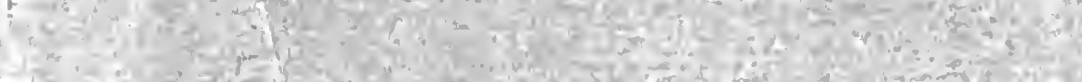

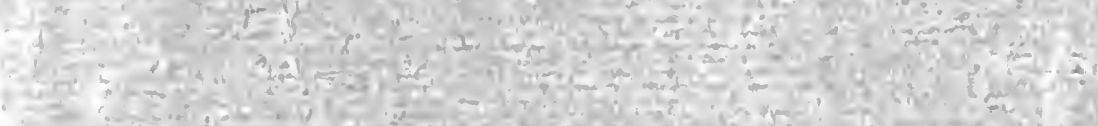

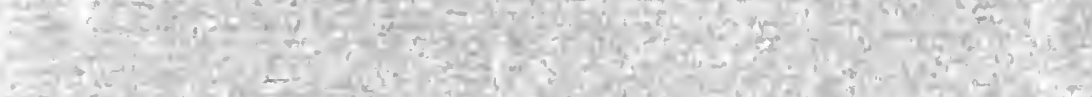

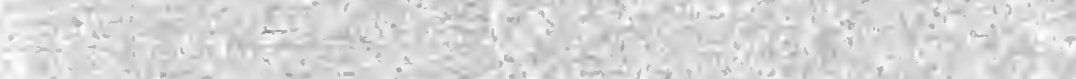

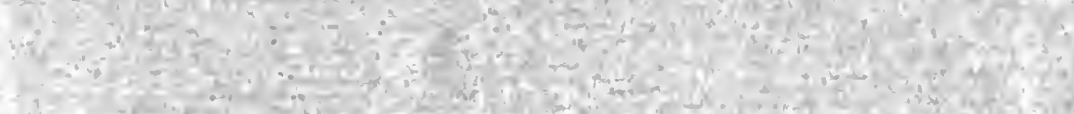

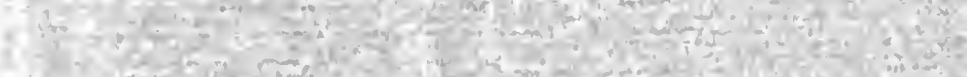

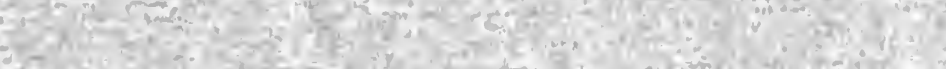

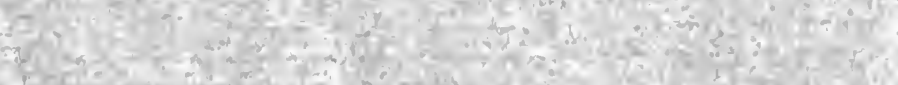

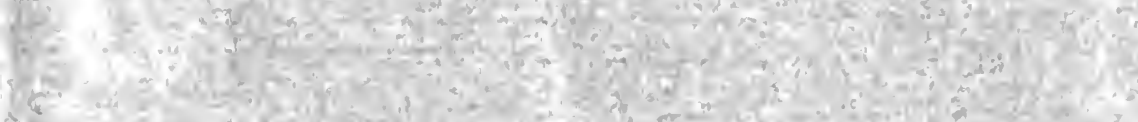
$+8$

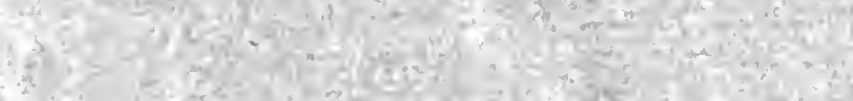

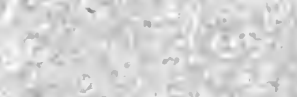

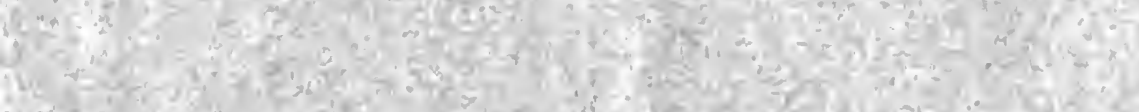

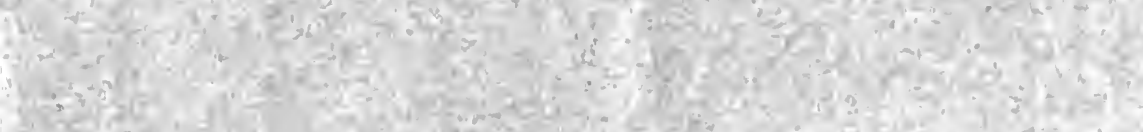
3


5

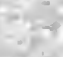
$4 x^{-15}=8$ (2) $x^{2}=1$

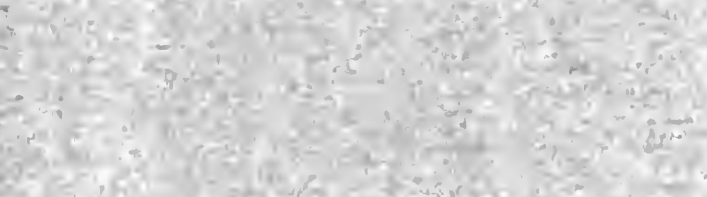

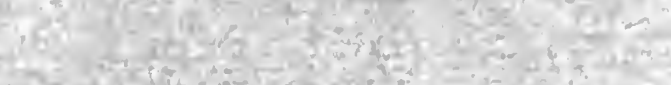

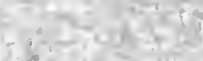

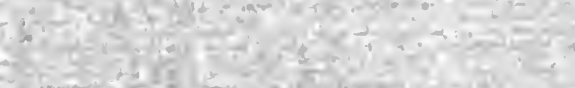

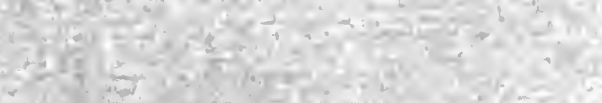

ton

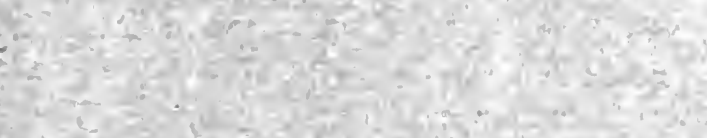



120. 


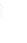

at

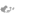


Digitized by the Internet Archive in 2007 with funding from Microsoft Corporation 


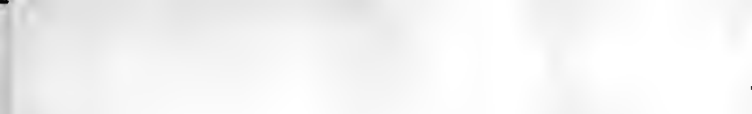

$$
\cdot
$$





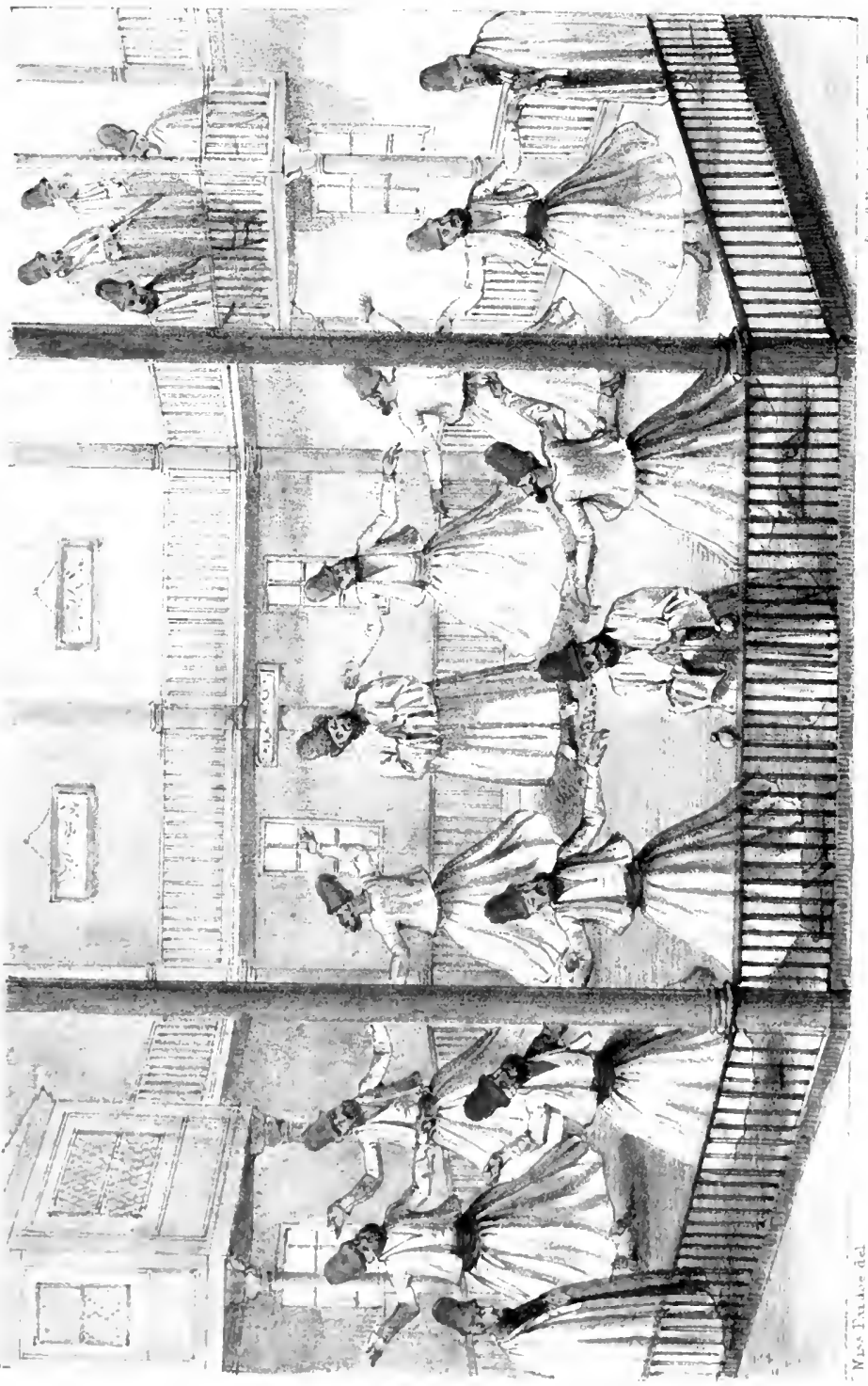




\title{
CITY OF THE SULTAN;
}

AND

\section{DOMESTIC MANNERS OF THE TURKS, IN 1836.}

\author{
B Y M I S S P A R D O E,
}

AUthor of "traits aNd traditions op portugal."

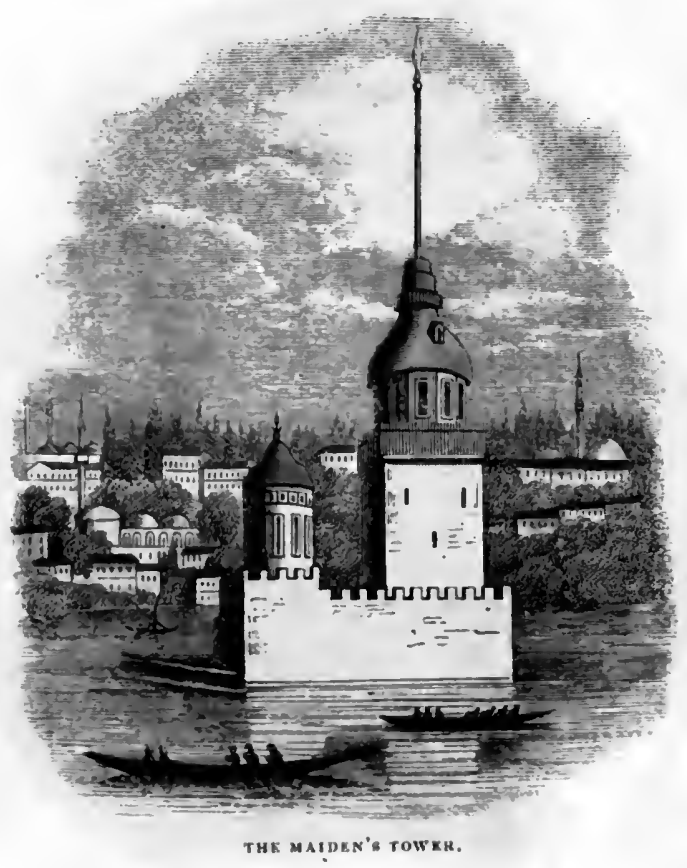

IN TWO VOLUMES.

VOI. I.

.LONDON :

HFNRY COLBURN, PUBLISHER, GREAT MARLBOROUGH STREET.

1837. 

TO HER

TO WHOM PROFESSION AND PANEGYRIC

WERE ALIKE SUPERFLUOUS ;

AND FROM WHOM,

DURING MY SOJOURN IN THE EAST,

I WAS FOR THE FIRST TIME SEPARATED-

TO MY LOVED AND LOVING MOTHER,

I DEDICATE THIS WORK. 
. ! '

\section{-}




\section{P R E F A C E.}

Is publishing the present work I feel that I should be deficient in self-justice, did I not state a few facts relatively to the numerous difficulties with which I have had to contend during its compilation.

The language of Turkey, in itself a serious impediment from its total dissimilarity to every European tongue, naturally raises a barrier between the native and the stranger, which is to the last only partially removed by the intervention of a third person; who, acting as an Interpreter, too frequently fritters away the soul of the conversation, even where he does not wilfully pervert its sense. But this drawback to a full and free intercourse with the natives, irritating and annoying as it is, sinks into insignificance, when compared with the myriad snares laid for the stranger, (and, above all, for the literary stranger) by party-spirit and political 
prejudice. The liberal-minded and high-hearted politician of Europe, even while he is straining every nerve, and exerting every energy, to support and strengthen the interests of his country, disdains to carry with him into private life the hatreds, the jealousies, and the suspicions, which, like rust on metal, mar the brightness of the spirit that harbours them. He does not reject a friend because his political tenets may be at variance with his own; nor overlook the amiable traits of his character, to dwell only upon his opposing prejudices and interests.

The height to which party-spirit is carried in Constantinople; or I should rather say, in the Frank quarter of Constantinople, would be laughable were it not mischievous. Even females are not free from the malaria which hovers like an atmosphere about the streets and "palaces" of Pera; and a traveller has not been domesticated a week among its inhabitants, ere he almost begins to believe that the destinies of the whole Eastern Empire hang upon the breath of a dozen individuals. With one party, Russia is the common sewer into which are poured all the reproach and the vituperation of indignant patriotism-with the other, England is the landmark towards which is pointed the finger of 
suspicion and defiance. All this may be very necessary, and very praiseworthy, as a matter of diplomacy; I suppose that it is both the one and the other. I have no opinion to offer on the subject. I merely venture to question the propriety of suffering such anti-social feelings to intrude into the bosom of private life; and to question the soundness of the judgment which would universally create a bad man out of a rival politician; and make the opening of one door the signal for the closing of another. It is said that the three plagues of Constantinople are Fire, Pestilence, and Dragomen; judging from what I saw and heard while there, I should be inclined to add a fourth, and to designate it, Politics. Certain it is that the faubourg of Pera always reminded me of an ant-hill; with its jostling, bustling, and racing for straws and trifles; and its ceaseless, restless struggling and striving to secure most inconsequent results.

That the great question of Eastern policy is a weighty and an important one, every thinking person must concede at once; but whether its final settlement will be advantageously accelerated by individual jealousies and individual hatreds is assuredly more problematical. "He who is not for me is against me," is the motto of 
viii

PREFACE.

every European resident in Turkey; for each, however incompetent he may be to judge of so intricate and comprehensive a subject, is nevertheless a loud and uncompromising politician. And, if the temporary sojourner in the East be resolved to belong to no clique, to pledge himself to no party, and to pursue a straight and independent path, as he would do in Europe, without lending himself to the views of either, he is certain to be suspected by both.

These are the briars which beset the way-side of the stranger in Turkey. He has not only to contend with the unaccustomed language and manners of the natives-to fling from him his European prejudices-and to learn to look candidly and dispassionately on a state of society, differing so widely from that which he has left - but when the wearied spirit would fain fall back, and repose itself for a while among more familiar and congenial habits, it has previously to undergo an ordeal as unexpected as it is irritating; and from which it requires no inconsiderable portion of moral courage to escape unshackled.

Such are the adventitious and unnecessary difficulties that have been gratuitously prepared for the Eastern traveller, and superadded to 
the natural impediments of the locality; and of these he has infinitely more reason to complain, than of the unavoidable obstacles which meet him at every step in his commerce with the natives. That the Turks as a people, and particularly the Turkish females, are shy of making the acquaintance of strangers, is most true; their habits and feelings do not lend themselves readily to a familiar intercourse with Europeans ; nor are they induced to make any extraordinary effort to overcome the prejudice with which they ever look upon a Frank, when they remember how absurdly and even cruelly they have been misrepresented by many a passing traveller, possessed neither of the time nor the opportunity to form a more efficient judgment.

When my father and myself left Europe, it was with the intention of visiting, not only Turkey, but also Greece, and Egypt; and we accordingly carried with us letters to influential individuals, resident in each of those interesting countries, whose assistance and friendship would have been most valuable to us. And, for the two or three first months of our sojourn in Constantinople, while yet unwilling to draw deductions, and to trust myself with inferences, which might, and probably would, ultimately prove erroneous, voL. $I$. 
I suffered myself to be misled by the assertions and opinions of prejudiced and party-spirited persons, and still maintained the same purpose. But, when awakened to a suspicion of the spiritthrall in which $I$ had been kept, I resolved to hazard no assertion or opinion which did not emanate from personal conviction, and I found that I could not prove an honest chronicler if I merely contented myself with a hurried and superficial survey of a country constituted like Turkey.

To this conviction must consequently be attributed the fact that the whole period of my sojourn in the East was passed in Constantinople, and a part of Asia Minor. But my personal disappointment will be overpaid, should it be conceded that $I$ have not failed in the attempt of affording to my readers a more just and complete insight into Turkish domestic life, than they have hitherto been enabled to obtain.

Bradenham Lodge, Bucks,

May 1837. 


\section{CONTENTS}

oF

\section{'THE FIRST VOLUME.}

\section{CHAPTER I.}

The Golden Horn-Stamboul in Snow-The Serai Bournou - Scutari - Galata-First View of Constantinople-St. Sophia and Solimaniè - Pera-Domestication of Aquatic Birds-Sounds at Sea - Caiques -Oriental Grouping-Armenian Costume-Reforms of Sultan Mahmoud-Dervishes - Eastern Jews-Evening-Illuminated Minarets - Romance versus Reason - Pain at Parting - Custom House of Galata-The East versus the West-Reminiscences of the Marseillois Functionaries - The British Consul at Marseilles - The Light-house at Syra-The Frank Quarter-Diplomatic Atmosphere-Straw Huts -Care of the Turks for Animals-Scene from Shakspeare Page 1

\section{CHAPTER II.}

Difficulty of Ingress to Turkish Houses - Steep Streets - The Harem -The Tandour-The Mangal-The Family - Female CostumeLuxurious Habits-The Ramazan-The Dining-room-The Widow -The Dinner - The Turks not Gastronomers-Oriental Hospitality - Ceremony of Ablution - The Massaldjhe-Alarm in the HaremThe Prayer - Evening Offering - Puerile Questions - Opium Primitive Painting - Splendid Beds - Avocations of a Turkish Lady - Oriental Coquetry-Shopping - Commercial Flirtations The Sultana Heybétoullah-A Turkish Carriage-T'The Charshees Arinenian Merchants - Greek Speculators - Perfumes and Embroidery

CHAPTER III.

Turning Dervishes - Appearance of the Tekiè - The Mausoleum Duties of the Dervishes - Chapel of the Convent - The Chief Priest 
- Dress of the Brotherhood - Melancholy Music-Solemnity of the Service-Mistakes of a Modern Traveller-Explanation of the Ceremony-The Prayer-The Kiss of Peace-Appearance of the Chapel - Religious Tolerance of the Turks - The French Renegade Sketch of Halet Effendi, the Founder of the Tekiè

\section{CHAPTER IV.}

Merchants of Galata-Palaces of Pera-Picturesque Style of BuildingThe Perotes-Social Subjects - Greeks, European and SchismaticAmbassadorial Residences-Entree of the Embassies-The Caruival -Soirées Dansantes-The Austrian Minister-Madame la Baronne -The Russian Minister-Madame de Boutenieff-The Masked Ball - Russian Supremacy - The Prussian Plenipotentiary - The Sardinian Chargé d'Affaires - Diplomacy Unhoused - Society of Pera

\section{CHAPTER V.}

The Greek Carnival - Kassim Pasha - The Marine Barrack - The Admiralty - Palace of the Capitan Pasha-Turkish Slips and Turkish Sailors-More Mistakes-Aqueduct of Justinian-The Serai - The Arsenal-The "Sweet Waters"-The Fanar - Interior of a Greek House-Courteous Reception-Patriarchal Custorns-Greek Ladies at Home-Confectionary and Coffee-A Greek Dinner-Ancient and Modern Greeks-A Few Words on Education-National Politeness -The Great Logotheti Aristarchi-His Politics - Sketch of his Father-His Domestic History-A Greek Breakfast-The Morning after a Ball-Greek Progress towards Civilization-Parallel between the Turk and the Greek $\quad$. $\quad$ - $\quad$. $\quad$. $\quad$. 65

\section{CHAPTER VI.}

Difliculty of Obtaining an Insight into Turkish Character - Inconvenience of Interpreters - Errors of Travellers - Ignorance of Resident Furopeans - Fables and Fable-mongers - Turkey, Local and Moral - Absence of Capital Crime - Police of Constantinople - Quiet Strcets-Sedate Mirth-Practical Philosophy of the Turks-National Emulation-Impossibility of Revolution-Mahmoud and his PeopleUnpopularity of the Sultan - Russian Interference - Vanity of the Turks - Russian Gold - Tenderuess of the Turks to Animals Penalty for Destroying a Dog - The English Sportsman-Fondness of the Turks for Children-Anecdote of the Reiss Effendi-Adopted Children - Love of the Musselmauns for their Mothers - Turkish indifference to Death-Their Burial-places-Fasts-The Turks in the Mosque-Contempt of the Natives for Europeans - Freedom of the Turkish Womeu-Inviolability of the Harem-Domestic Economy of 
the Harem - Turkish Slaves - Anecdote of a Slave of Achmet Pasha-Cleanliness of Turkish Houses-The Real Romance of the East

\section{CHAPTER VII.}

The Harem of Mustafa Effendi - The Ladies of the Harem-Etiquettical Observances of the Harem-Ceremonies of the Salemliek Jealousy of Precedence among the Turkish Women - Apartment of the Effendi-Eastern Passion for Diamonds-Personal Appearance of Mustafa Effendi-The little Slave-girl-Slavery in 'Turkey-Gallant Present-The Dinner - Turkish Cookery - Illuminated MosquesThe Bokshaliks-The Toilet after the Bath-History of an Odalique -Stupid Husbands-Reciprocal Commiseration - Errors of a Modern French 'Traveller-Privacy of the Women's Apartments-Anecdote of the Wife of the Kiara Bey-The Baïram Bokshalik-My Sleepingroom-Forethought of Turkish Hospitality - Farewell to Falma Hanoum-Deuse Crowd-Turkish Mob-Turkish Officers-Military Difficulty - The " Lower Orders" - Tolerance of the Orientals to-

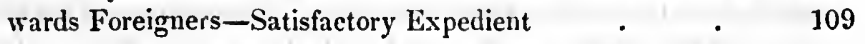

\section{CHAPTER VIII.}

Bath-room of Scodra Pasha - Fondness of the Eastern Women for the Bath-The Outer Hall - The Proprietress'- Female Groups - The Cooling-room-The Great Hall-The Fountains-The Bathing Women-The Dinner-Apology for the Turkish Ladies 129

\section{CHAPTER IX.}

Cheerful Cemeteries - Burial-ground of Pera - Superiority of the Turkisl Cemeteries-Cypresses-Singular Superstition-The Grand Champs-Gruek Grave-yard - Sultan Selim's Barrack -Village of St. Demetrius - European Burial-ground - Grave-stones - The Kiosk-Noble View - Legend of the Maiden's Tower - Plague Hospital of the 'Turks-The Plague-Caïque-Armenian CeıneteryCurious Inscriptions-Turkish Burial-place-Distinctive Head-stones -Graves of the Janissaries-Wild Superstition-Cemetery of Scutari - Splendid Cypresses - Ancient Prophecy - Extent of Burialground-The Headless Dead-Exclusive Enclosures-Aspect of the Cemetery from the Summer Palace of Heybètoullah Sultane Local Superstition-The Damnèd Souls . $\quad$. $\quad 138$

\section{CHAPTER $\mathrm{X}$.}

Character of the Constantinopolitan Greeks-The Greek Colony at the Fanar - Vogoride, Logotheti, and Angiolopolo-Political SentimentChateaubriand at the Duke de Rovigo's - Biting Criticism-Greek 
Chambers - "What's in a Name?"- Custom of Burning Perfumes -The Pastille of the Seraglio - Turkish Cosmetics - Eastern Beauty .

157

\section{CHAPTER XI.}

The Kourban-Baïram - Politeness of Mustafa Effendi - Depressing Recollections-Unquiet Night-Midnight March-Turkish CoffeeA Latticed Araba-The Mosque of Sultan Aclmet-Beautiful coupd'cil-Dress of the Turkish Children-Restlessness of the FranksThe Festival of Sacrifice - Old Jewish Rite - The Turkish WifeSun-rise - Appearance of the Troops - Turkish Ladies-Group of Field Officers - The Sultan's Stud - Magnificent Trappings - The Seraskier Pasha - The Great Officers of State - The ProcessionThe Sultan-Imperial Curiosity-The Chèik-Islam-Costume of the Sultan-Japanese Superstition-Vanity of Sultan Mahmoud-The Hairdresser of Halil Pasha-Rapid Promotion-Oriental Salutations -Halil Pasha-Saïd Pasha-Unruly Horses-The Valley of the "Sweet Waters"-Pera

171

\section{CHAPTER XII.}

The Military College - Achmet Pasha and Azmi Bey-Stuỏy of Azmi Bey-His grateful Memories of England and the English-The Establishment-The Lithographic Presses - Extemporaneous Poetry Halls of Study - Number of Students - Mathematical Hall - The Sultan's Gallery-The Mosque-The Mufti-The Turkish Creed The Imperial Closet - The Gallery of the Imperial Suite - The Retiring-Room-The Printing-Office-The Hospital-The Refectory -The Professor of Fortification - Negro Officers-Moral Condition of the College - Courtesy of the Officers - Deficiencies of the Professors - The Turks a Reading People - Object of the InstitutionReasons of its Failure - Smiling Enemies-Forlorn Hope-Russian Influence-Saduk $\Lambda$ gha $-\Lambda$ chmet Pasha $-\Lambda$ zmi Bey $-\Lambda$ pology for my Prolixity

\section{CHAPTER XIII.}

Invitation from Mustapha Pasha of Scodra - The Caïque, and the Caïquejhes - How to Travel in a Caïque - Hasty Glances - SelfGratulation - Scutari - Imperial Superstition - The Seraglio Point -Dolına Batchè - Beshiktash - The Turning Dervishes-Beglièrbey-The Kiosks $-\Lambda$ Dilemma-A Ruined Palace- $\Lambda$ n Introduction $-\Lambda$ 'Turkish Beauty $-\Lambda$ Discovery $-\mathbf{A}$ New AcquaintanceThe Buyuk Hanoum - Fatiguing Walk - Palace of Mustapha Pasha-The Harem - I'urkish Dyes-Ceremonies of Reception Turkish Establishment-The Buyuk Hanoum-Turkish Chaplets- 
The Imperial Firman-Pearls, Rubies, and Emeralds-The Favourite Odalique-Heyminè Hanoum-A Conversation on Politics-Scodra Pasha-Singular Coincidence-Convenience of the Turkish KitchenLixury of the Table-Cuquetry of the Chibouk-Turkish Mode of Lighting the Apartment3 - Gentleness towards the Slaves - Interesting Reminiscences - Domestic Details - Dilaram Hanoum - A Paragraph on Pearls - $\mathbf{A}$ Turkish Mirror - A Summons - Scodra Pasha-Motives for Revolt-The Imperial Envoy - Submission Ready Wit of the Pasha's Son - The Reception Room-Personal Appearance of the Scodra Pasha-Inconvenient Courtesy-Conversation on England - Philosophy-Pleasant Dreams-The PlagueSmitten

216

\section{CHAPTER XIV.}

Procession of Betrothal-Preliminary Ceremonies-The Mantle of Mahomet-The Palace of the Seraskier Pasha - The Palace Square Picturesque Groups-An Interior-Turkish Children-Oriental Curiosity-Costume of the Turkish Children - Military Music-The Procession - Hurried Departure of the Crowd-The Seraskier's Tower-The Fire Guard-Candidates for the Imperial Bride-Imperial Expedient_Saïd Pasha_Policy of the Seraskier - An Andience -The Biter Bitten - Ingenious Ruse - Sublime Economy-Brilliant Traffic - The Danger of Delay - The Marriage Gifts - An Interesting Interview 255

\section{CHAPTER XV.}

Fine Scenery-The Coast of Asia-Turkish Cemeteries-The Imperial Serä-The Golden Horn-Mount Olympus-The Arabajhe-The Araba-The Persian Kiosk-The Barrack of Scutari-The Mosque of Selim III.-The Slipper of the Sultana Validè-The Imperial Guard - Military Material-The Macaroni Manufactory-Sublime Targets -A Major of the Imperial Guard-Triumph of Utilitarianism - The Rise of the Vines-The Holy Tomb - Encampments of the Plaguesmitten-The Setting Sun-Return to Europe-The Square of Topphamuè

276

\section{CHAPTER XVI.}

Turkish Superstitions-Auguries - The Court Astrologer - The Evil Eye-Danger of Blue Eyes-Imperial Firman-The Babaluk-The Ceremony-Sable Pythonesses-Witcheraft . 289

\section{CHAPTER XVII.}

Imperial Invitation - Disagreeable $\Lambda$ dventure - Executed CriminalEfficacy of Wayside Executions - Tardy Conversions - Mistaken 
Humanity - Summary Mode of Execution - The Palace of Asmè Sultane-Entrance of the Harem-Costume of the Slares-Nazip Hanoum-Ceremonious Recepion-The Adopted Daughter-Costume of the Ladies of the Serai-Beauty of the Slaves-Extraordinary Arrangement - Rejected Addresses - The Imperial Lover Sacredness of Adoption in Turkey - Romantic CorrespondenceLadies of the Household - The Mother of the Slaves-Peroussè Hanoum - Crowded Audience-The Imperial Odalique-Music of the Harem - The New Pet-The Kislar-Agla-The "Light of the Harem "-The Poetical Sultan-Indisposition of the Sultana-The Palace Gardeus-The Imperial $\Lambda$ partments - The Dancing GirlReluctant Departure-Ballad by Peroussè Hanoum • 298

\section{CHAPTER XVIII.}

Kahaitchana-The Barbyses-The Valley of the Sweet Waters-Imperial Procession - National Interdict - Picturesque Scene - The Princess Salihè and her Infaut - Forbearance of the Sultan - The Toxopholites-Imperial Monopoly-Passion of the Sultan for Archery -Record-Columns-The Odalique's Grave-The Lost One-Azmè Sultane-Imperial Courtesy-A Drive through the Valley

\section{CHAPTER XIX.}

Easter with the Greeks-Greek Church at Pera-Women's GalleryInterior of a Greek Church-The Sanctuary-The Screen-Throne of the Patriarch-The Holy Sepulchre-Singular Appearance of the Congregation-Sociability of the Ladies - L'Echelle des MortsShipping - Boats and Boatmen - Chureh of the Fanar - Ancient Screen - Treasure Chests - The Sanctuary-Private Chapels-A Pious Illumination - Priests' House-Prison - Remedy against Mahomedanism - Midnight Mass - Unexpected Greetings - The Patriarch - Ingotheti - Russian Secretaries - Russian Supremacy in Turkey-Affinity of Religion between the Greeks and RussiansThe Homage-Pious Confusion-Patriarch's Palace-Lovely NightScene-Midnight Procession-Serious Impressions-Suffocating Heat -Dawn.

332

\section{CHAPTER XX.}

Feasting after Fasting-Visit to the Patriarch-Gorgeous ProcessionInconvenient Enthusiasm-Indisposition of the Patriareh-The Ceremony of Unrobing-The Impromptu Fair-The Patriareh at Home

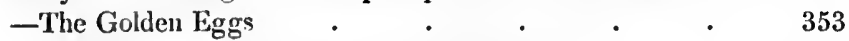

\section{CHAPTER XXI.}

High Street of Pera-Dangers and Donkeys-Travelling in an Araba 
-Fondness of the Orientals for their Cemeteries-Singular Spectacle -Moral Supineness of the Armenians-M. Nubar-The Fair-Arinenian Dance - Anti-Exclusives - Water Venders - Being à la Franka-Wrestling Rings-The Battle of the Sects

\section{CHAPTER XXII.}

The Mosques at Midnight-Baron Rothschild-Firmans and OrdersA Proposition-Masquerading-St. Sophia by Lamplight-The Congregation-The Mosque of Sultan Achmet-Colossal Pillars-Return to the Harem-The Cheirk-Islam-Count Bathiany-The Party-St. Sophia by Daylight - Erroneous Impression - Turkish ParadisePiety of the Turkish Women-The Vexed Traveller - Disappointment-Confusion of Architecture - The Sweating Stone - Women's Gallery - View from the Gallery - Gog and Magog at Constantinople - The Impenetrable Door-Ancient Tradition - Leads of the Mosque-Gallery of the Dome-The Doves - The Atmeidan-The Tree of Groans- The Mosque of Sultan Aclimet-Antique VasesHistorical Pulpit-The Inner Court-The Six Minarets-The Mosque of Solimaniè - Painted Windows - Ground-plan of the Principal Mosques-The Treasury of Solimaniè- Mausoleum of Solyman the Magnificent-Model of the Mosque at Mecca - Mansoleums in General-Indispensable Accessories-The Medresch-Mosque of Sultan Mahmoud at Topp-hannè

373

\section{CHAPTER XXIII.}

Antiquities of Constantinople - Ismäel Effendi - The Atmeidan-The Obelisk-The Delphic 'Tripod - The Column of Constantine - The Tchernberlè Tasch-The Cistern of the Thousand and One Columns - The Boudroum - The Roman Dungeons-Yèrè-Batan-Seraï The Lost Traveller-Extent of the Cistern-Aqueduct of Justinian -Palace of Constautine - Tomb of Heraclius - The Seven Towers - An Ambassador in Search of Truth - Tortures of the Prison - A Legend of the Seven Towers _ . . . . . $\quad 405$

\section{CHAPTER XXIV.}

Balouclè-TheNew Church-Delightful Road-Eyoub-The Cemetery -The Rebel's Grave-The Mosque of Blood - The Hill of Graves - The Seven Towers-The Palace of Belisarins - The City Walls - Faster Festivities - The Turkish Araba - The Armenian Carriage-Travellers-Turkish Women - Seridjhes-Persians-Irregular Troops-The Plain of Balouclè-Laughable Mistake-Extraordinary Discretion - The Clıurch of Balouclè - The Holy Well Absurd Tradition - The Chapel Vault - Enthusiasm of the Greeks 
- A Pleasant Draught - Greek Substitute for a Bell - Violent Storm

\section{CHAPTER XXV.}

Figurative Gratitude of the Seraskier Pasha - Eastern Hyperbole Reminiscences of Past Years-A Vision Realized-Strong Contrasts -The Marriage Fêtes - Popular Excitement - Crowded StreetsThe Auspicious Day-Extravagant Expectations-The Great Cemetery - Dolma Batchè - The Grand Armoury - Turkish Women Tents of the Pashas-The Bosphorus - Preparations-InvocationThe Illuminated Bosphorus-A Stretch of Fancy-A Painful Recollection - Natural Beauties of the Bosphorus - The Grave-Yard Evening Amusements-Well Conducted Population 446

\section{CHAPTER XXVI.}

Repetition - The Esplanade - The Kiosk and the Pavilion - A Short Cut-Dense Crowd-A Friend at Court-Curious Coup d' Eil-The Arena - The Orchestra - First Act of the Comedy - Disgusting Exhibition-The Birth of the Ballet-Dancing Boys-Second Act of the Drama-Insult to the Turkish Women-The Provost Marshal -Yusuf Pasha, the Traitor-Clemency of the Sultan-Forbearance of an Oriental Mob-Renewal of the Ballet-Last Act of the Drama -Theatrical Decorations-Watch-dogs and Chinese-Procession of the Trades - Frank Merchants - Thieves and Judges - Bedouin Tumblers-Fondness of the Pashas for Dancing - The Wise Men of the East . $\quad$. $\quad$. $\quad$. . . 460

\section{CHAPTER XXVII.}

Succession of Banquets-The Chèik Islam and the Clergy-Sectarian Prejudices-The Military Staff - The Naval Chiefs - The Imperial Houselıold-The Pashas-The Grand Vizier-Magnificent Procession-Night Scene on the Bosphorus - The Palace of the Seraskier Pasha-Palace of Azmè Sultane-Midnight Serenade-Pretty Truants-The Shore of Asia - Ambassadorial Banquet - War Dance$\begin{array}{llll}\text { Beautiful Effects of Light } \quad \text {. } & 478\end{array}$

\section{CHAPTER XXVIII.}

Monotonous Entertainments - Bridal Preparations - Common Interest - Appearance of the Surrounding Country - Ride to ArnautkeuiSight-loving Ladies-Glances and Greetings-Pictorial Grouping The Procession-The Trousseau-A Steeple-Chase

\section{CHAPTER XXXI.}

The Bridal Day - Ceremony of Acceptance-The Crowd-The Kislar 
Agha and the Court Astrologer - Order of the Procession - The Russian Coach - The Paslia and the Attachés-The Seraskier Wives of the Pashas-The Sultan and the Georgian Slave . 500

\section{CHAPTER XXX.}

A New Rejoicing - Scholastic Processions - Change in the Valley The Odalique's Grave - The Palace of Eyoub - The State Apartments-Return to Pera 


\section{L L U S T R A T I O N S.}

VOL. I.

Chapel of the Turning Dervishes

The Maiden's Tower

Military College

Palace of the Sweet Waters

A Street in Pera

Column of Constantine and Egyptian Tripor

The Seven Towers .

$\begin{array}{crr} & \text { Frontispiece. } \\ \text { Vignette } & \text { Title-page. } \\ \text {. } & \text {. } & 196 \\ . & . & 324 \\ . & . & 361 \\ . & . & 407 \\ . & . & 421\end{array}$

VOL. II.

Yèrè Batan Seraï

Frontispiece.

Tower of Galata

Vignette Title-page.

Ruins of the Imperial Palace

28

Roman Bridge at Broussa

36

Roof of Oulou Jamè from the Garden of the Greek Church . 40

$\begin{array}{lllllll}\text { Turkish Mausoleum } \quad \text {. } & \text {. } & 53\end{array}$

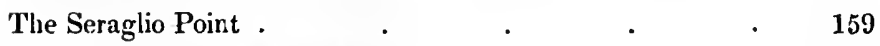

Part of the Valley of Guiuk-Suy _ . . $\quad$ - 244

Castle of Mahomet . $\quad$ - $\quad$. $\quad 256$

Column of Theodosius $\quad$. $\quad$. $\quad$. $\quad 358$

View near Fanaraki, in Asia . $\quad$. $\quad 406$ 
THE

\section{CITY OF THE SULTAN.}

\section{CHAP'IER I.}

The Golden Horn-Stamboul in Snow-The Serai Bournou - Scutari -Galata-First View of Constantinople-St. Sophia and Solimaniè - Pera-Domestication of Aquatic Birds - Sounds at Sea - Caĩques -Oriental Grouping-Armenian Costume-Reforms of Sultan Mahınoud-Dervishes - Lastern Jews-Evening-Illuminated Minarets - Romance versus Reason - Pain at Parting - Custom House of Galata - The East versus the West - Reminiscences of Marseillois Functionaries - The British Consul at Marseilles - The Ijight-house at Syra-The Frank Quarter-Diplcmatic Atmosphere-Straw Huts -Care of the Turks for Animals-A Scene from Shakspeare.

Ir was on the 30th of December, 1835, that we anchored in the Golden Horn ; my long-indulged hopes were at length realized, and the Queen of Cities was before me, throned on her peopled hills, with the silver Bosphorus, garlanded with palaces, flowing at her feet!

It was with difficulty that I could drag myself upon deck after the night of intense suffering which I had passed in the sea of Marmora, and, when I did succeed in doing so, the vessel

VOL. 1. 
was already under the walls of the Seraglio garden, and advancing rapidly towards her anchorage. The atmosphere was laden with snow, and I beheld Stamboul for the first time clad in the ermine mantle of the sternest of seasons. Yet, even thus, the most powerful feeling that unravelled itself from the chaos of sensations which thronged upon me was one of unalloyed delight. How could it be otherwise? I seemed to look on fairy-land - to behold the embodiment of my wildest visions - to be the denizen of a new world.

Queenly Stamboul! the myriad sounds of her streets came to us mellowed by the distance; and, as we swept along, the whole glory of her princely port burst upon our view! The gilded palace of Mahmoud, with its glittering gate and overtopping cypresses, among which may be distinguished the buildings of the Serai, were soon passed; behind us, in the distance, was Scutari, looking down in beauty on the channel, whose waves reflected the graceful outline of its tapering minarets, and shrouded themselves for an instant in the dark shadows of its funereal grove. Galata was beside us, with its mouldering walls and warlike memories; and the vessel trembled as the chain fell heavily into the water, and we anchored in the midst of the crowd of shipping that already thronged the harbour. On the opposite shore clustered the painted dwel- 
lings of Constantinople, the party-coloured garment of the "seven hills" - the tall cypresses that overshadowed her houses, and the stately plane trees, which more than rivalled them in beauty, bent their haughty heads beneath the weight of accumulated snows. Here and there, a cluster of graceful minarets cut sharply against the sky; while the ample dome of the mosque to which they belonged, and the roofs of the dwellings that nestled at their base, lay steeped in the same chill livery. Eagerly did I seek to distinguish those of St. Sophia, and the smaller but far more elegant Solimaniè, the shrine of the Prophet's Beard, with its four minarets, and its cloistered courts; and it was not without reluctance that I turned away, to mark where the thronging houses of Pera clomb with magnificent profusion the amphitheatre of hills which dominate the treasure-laden port.

As my gaze wandered along the shore, and, passing by the extensive grove of cypresses that wave above the burying-ground, once more followed the course of the Bosphorus, I watched the waves as they washed the very foundation of the dwellings that skirt it, until I saw them chafing and struggling at the base of the barrack of Topp-hannè, and at intervals flinging themselves high into the air above its very roof.

To. an European eye, the scene, independently of its surpassing beauty and utter novelty, pos- 
sessed two features peculiarly striking; the extreme vicinity of the houses to the sea, which in many instances they positively overhang; and the vast number of aquatic fowl that throng: the harbour. Seagulls were flying past us in clouds, and sporting like domestic birds about the vessel, while many of the adjoining roofs were clustered with them; the wild-duck and the water-hen were diving under our very stern in search of food; and shoals of porpoises were every moment rolling by, turning up their white bellies to the light, and revelling in safety amid the sounds and sights of a mighty city, as though unconscious of the vicinity of danger. How long, I involuntarily asked myself, would this extraordinary confidence in man be repaid by impunity in an English port? and the answer was by no means pleasing to my national pride.

As I looked round upon the shipping, the language of many lands came on the wind. Here the deep "Brig a-hoy!" of the British seaman boomed along the ripple; there, the shrill cry of the Greek mariner rang through the air : at intervals, the full rich strain of the dark-eyed Italian relieved the wild monotonous chant of the 'Turk; while the cry of the sea-boy from the rigging was answered by the stern brief tones of the weather-beaten sailor on the deck.

Every instant a graceful caïque, with its long. sharp prow and gilded ornaments, shot past the 
ship: now freighted with a bearded and turbaned Turk, squatted upon his carpet at the bottom of the boat, pipe in hand, and muffled closely in his furred pelisse, the very personification of luxurious idleness; and attended by his red-capped and blue-coated domestic, who was sometimes a thick-lipped negro, but more frequently a keen-eyed and mustachioed musselmaun-now tenanted by a group of women, huddled closely together, and wearing the yashmac, or veil of white muslin, which covers all the face except the eyes and nose, and gives to the wearer the appearance of an animated corpse; some of them, as they passed, languidly breathing out their harmonious Turkish, which in a female mouth is almost music.

Then came a third, gliding along like a nautilus, with its small white sail; and bearing a bevy of Greeks, whose large flashing eyes gleamed out beneath the unbecoming fèz, or cap of red cloth, with its purple silk tassel, and ornament of cut paper, bound round the head among the lower classes, by a thick black shawl, tightly twisted. 'This was followed by a fourth, impelled by two lusty rowers, wherein the round hats and angular costume of a party of Franks forced your thoughts back upon the country that you had left, only to be recalled the next instant by a freight of Armenian merchants returning from the Charshees of Con- 
stantinople to their dwellings at Galata and Pera. As I looked on the fine countenances, the noble figures, and the animated expression of the party, how did I deprecate their shaven heads, and the use of the frightful calpac, which I cannot more appropriately describe than by comparing it to the iron pots used in English kitchens, inverted! The graceful pelisse, however, almost makes amends for the monstrous head-gear, as its costly garniture of sable or marten-skin falls back, and reveals the robe of rich silk, and the cachemire shawl folded about the waist. Altogether, I was more struck with the Armenian than the Turkish costume; and there is a refinement and tenue about the wearers singularly attractive. Their well-trimmed mustachioes, their stained and carefully-shaped eyebrows, their exceeding cleanliness, in short, their whole appearance, interests the eye at once; nor must I pass over without remark their jewelled rings, and their pipes of almost countless cost, grasped by fingers so white and slender that they would grace a woman.

While I am on the subject of costume, I cannot forbear to record my regret as I beheld in every direction the hideous and unmeaning $f e ̀ z$, which has almost superseded the gorgeous turban of muslin and cachemire: indeed, I was nearly tempted in my woman wrath to consider all the admirable reforms, wrought by Sultan Mah- 
moud in his capital, overbalanced by the frightful changes that he has made in the national costume, by introducing a mere caricature of that worst of all originals - the stiff, starch, angular European dress. The costly turban, that bound the brow like a diadem, and relieved by the richness of its tints the dark hue of the other garments, has now almost entirely disappeared from the streets; and a group of 'Turks look in the distance like a bed of poppies; the flowing robe of silk or of woollen has been flung aside for the ill-made and awkward surtout of blue cloth; and the waist, which was once girdled with a shawl of cachemire, is now compressed by two brass buttons!

The Dervish, or domestic priest, for such he may truly be called, whose holy profession, instead of rendering him a distinct individual, suffers him to mingle like his fellow-men in all the avocations, and to participate in all the socialities of life; which permits him to read his offices behind the counter of his shop, and to bring up his family to the cares and customs of every-day life; and who is bound only by his own voluntary act to a steady continuance in the self-imposed duties that he is at liberty to cast aside when they become irksome to him; the holy Dervish frequently passed us in his turn, seated at the bottom of the caïque, with an open volume on his knees, and distinguished from the lay-'Turk by 
his geulaf, or high hat of grey felt. Then came a group of Jews, chattering and gesticulating; with their amplecloaks, and small dingy-coloured caps, surrounded by a projecting band of brown and white cotton, whose singular pattern has misled a modern traveller so far as to induce him to state that it is " a white handkerchief, inscribed with some Hebrew sentences from their law."

Thus far, I could compare the port of Constantinople to nothing less delightful than poetry put into action. The novel character of the scenery - the ever-shifting, picturesque, and graceful groups-the constant flitting past of the fairy-like caïques-the strange tongues the dark, wild eyes-all conspired to rivet me to the deck, despite the bitterness of the weather.

Evening came-and the spell deepened. We had arrived during the Turkish Ramazan, or Lent, and, as the twilight gathered about us, the minarets of all the mosques were brilliantly illuminated. Nothing could exceed the magical effect of the scene; the darkness of the hour concealed the outline of the graceful shafts of these etherial columns, while the circles of light which girdled them almost at their extreme height formed a triple crown of living diamonds. Below these depended (filling the intermediate space) shifting figures of fire, succeeding cach other with wonderful rapidity and precision : now it was a house, now a group of cypresses, then a vessel. 
or an anchor, or a spray of flowers; and these changes were effected, as I afterwards discovered, in the most simple and inartificial manner. Cords are slung from minaret to minaret, from whence depend others, to which the lamps are attached; and the raising or lowering of these cords, according to a previous design, produces the apparently magic transitions which render the illuminations of Stamboul unlike those of any European capital.

But.I can scarcely forgive myself for thus accounting in so matter-of-fact a manner for the beautiful illusions that wrought so powerfully, on my own fancy. I detest the spirit which reduces every thing to plain reason, and pleases itself by tracing effects to causes, where the only result of the research must be the utter annihilation of all romance, and the extinction of all wonder. The flowers that blossom by the wayside of life are less beautiful when we have torn them leaf by leaf asunder, to analyze their properties, and to determine their classes, than when we first inhale their perfume, and delight in their lovely tints, heedless of all save the enjoyment which they impart. The man of science may decry, and the philosopher may condemn, such a mode of reasoning; but really, in these days of utilitarianism, when all things are redfreed to rule, and laid bare by wisdom, it is desirable to reserve a niche or 
two unprofaned by "the schoolmaster," where fancy may plume herself unchidden, despite the never-ending analysis of a theorising world!

My continued indisposition compelled my father and myself to remain another day on board ; but I scarcely felt the necessity irksome. All was so novel and so full of interest around me, and my protracted voyage had so thoroughly inured me to privation and inconvenience, that I was enabled to enjoy the scene without one regret for land. The same shifting panorama, the same endless varieties of sight and sound, occupied the day; and the same magic illusions lent a brilliancy and a poetry to the night.

Smile, ye whose exclusiveness has girdled you with a fictitious and imaginary circle, beyond which ye have neither sympathies nor sensibilities-smile if ye will, as I declare that when the moment came in which I was to quit the good brig, that had borne us so bravely through storm and peril - the last tangible link between ourselves and the far land that we had loved and left-I almost regretted that I trod her snowheaped and luggage-cumbered deck for the last time; and that, as the crew clustered round us, to secure a parting look and a parting word, a tear sprang to my eye. How impossible does it appear to me to forget, at such a time as this, those who have shared with you the perils and the protection of a long and arduous voyage! 
From the sturdy seaman who had stood at the helm, and contended with the drear and drenching midnight sea, to the venturous boy who had climbed the bending mast to secure the remnants of the shivered sail, every face had long been familiar to me. I could call each by name; nor was there one among them to whom I had not, on some occasion, been indebted for those rude but ready courtesies which, however insignificant in themselves, are valuable to the uninitiated and helpless at sea.

On the Ist of January, 1836, we landed at the Custom House stairs at Galata, amid a perfect storm of snow and wind; nor must I omit the fact that we did so without "let or hindrance" from the officers of the establishment. The only inquiry made was, whether we had brought out any merchandize, and, our reply being in the negative, coupled with the assurance that we were merely travellers, and that our packages consisted simply of personal necessaries, we were civilly desired to pass on.

I could not avoid contrasting this mode of action in the "barbarous" East, with that of " civilized" Europe, where even your very person is not sacred from the investigation of lowbred and low-minded individuals, from whose officious and frequently impertinent contact you can secure yourself only by a bribe. Perhaps the contrast struck me the more forcibly that 
we had embarked from Marseilles, where all which concerns either the Douane or the Bureau de Santé is à la rigueur-where you are obliged to pay a duty on what you take out of the city as well as what you bring into it - pay for a certificate of health to persons who do not know that you have half a dozen hours to live - and - hear this, ye travel-stricken English, who leave your country to breathe freely for a while in lands wherein ye may dwell without the extortion of taxes - pay your own Consul for permission to embark!

This last demand rankles more than all with a British subject, who may quit his birth-place unquestioned, and who hugs himself with the belief that nothing pitiful or paltry can be connected with the idea of an Englishman by the foreigners among whom he is about to sojourn. He has to learn his error, and the opportunity is afforded to him at Marseilles, where the natives of every other country under Heaven are free to leave the port as they list, when they have satisfied the demands of the local functionaries; while the English alone have a special claimant in their own Consul, the individual appointed by the British government to' "assist" and "protect" his fellowsubjects-by whom they are only let loose upon the world at the rate of six francs and a half a head! And for this "consideration" they be- 
come the happy possessors of a "Permission to Embark" from a man whom they have probably never seen, and who has not furthered for them a single view, nor removed a single difficulty. To this it may be answered that, had they required his assistance, they might have demanded it, which must be conceded at once, but, nevertheless, the success of their demand is more than problematical-and the arrangement is perfectly on a par with that of the Greeks in the island of Syra, who, when we cast anchor in their port, claimed, among other dues, a dollar and a half for the signal-light; and, on being reminded that there had been no light at the station for several previous nights, with the additional information that we had narrowly escaped wreck in consequence, coolly replied, that all we said was very true, but that there would shortly be a fire kindled there regularly - that they wanted money - and that, in short, the dollar and a half must be paid; but herefrom we at least took our departure without asking leave of our own Consul.

From the Custom House of Galata, we proceeded up a steep ascent to Pera, the quarter of the Franks-the focus of diplomacy-where every lip murmurs "His Excellency," and secretaries, interpreters, and attachés are

"Thick as the leaves on Valombrosa."

But, alas! on the 1st day of January, Pera, 
Galata, and their environs, were one huge snowball. As it was Friday, the Turkish Sabbath, and, moreover, a Friday of the Ramazan, every shop was shut; and the few foot passengers who passed us by hurried on as though impatient of exposure to so inclement an atmosphere. As most of the streets are impassable for carriages, and as the sedan-chairs which supply, however imperfectly, the place of these convenient (and almost, as I had hitherto considered, indispensable) articles, are all private property, we were e'en obliged to "thread our weary way" as patiently as we could-now buried up to our knees in snow, and anon immersed above our ancles in water, when we chanced to plunge into one of those huge holes which give so interesting an inequality to the surface of Turkish paving.

Nevertheless, despite the difficulties that obstructed our progress, I could not avoid remarking the little straw huts built at intervals along the streets, for the accommodation and comfort of the otherwise homeless dog's that throng every avenue of the town. There they lay, crouched down snugly, too much chilled to welcome us with the chorus of barking that they usually bestow on travellers: a species of loud and inconvenient greeting with which we were by no means sorry to dispense. In addition to this shelter, food is every day dispensed by the inhabitants to the vagrant animals who, 
having no specific owners, are, to use the approved phraseology of genteel alms-asking, "wholly dependent on the charitable for support." And it is a singular fact that these selfconstituted scavengers exercise a kind of internal economy which almost appears to exceed the boundaries of mere instinct; they have their defined "walks," or haunts, and woe betide the strange cur who intrudes on the privileges of his neighbours; he is hunted, upbraided with growls and barks, beset on all sides, even bitten in cases of obstinate contumacy, and universally obliged to retreat within his own limits. Their numbers have, as I was informed, greatly decreased of late years, but they are still very considerable.

As we passed along, a door opened, and forth stepped the most magnificent-looking individual whom I ever saw: he had a costly cachemire twined about his waist, his flowing robes were richly furred, and he turned the key in the lock with an air of such blended anxiety and dignity, that I involuntarily thought of the Jew of Shakspeare; and I expected at the moment to hear him exclaim, "Shut the door, Jessica, shut the door, I say!" But, alas! he moved away, and no sweet Jessica flung back the casement to reply. 


\section{CHAPTER II.}

Difficulty of Ingress to Turkish Houses - Steep Streets - The Harem -The Tandour-The Mangal-The Family - Female CostumeLuxurious Habits-The Ramazan-The Dining-room-The Widow - The Dinner - The Turks not Gastronomers-Oriental Hospitality - Ceremony of Ablution - The Massaldjhe-Alarm in the HaremThe Prayer - Evening Offering - Puerile Questions - Opium Primitive Painting - Splendid Beds - Avocations of a Turkish Lady - Oriental Coquetry-Shopping - Commercial Flirtations The Sultana Heybétoullah-A Turkish Carriage-T'The Charshees Armenian Merchants - Greek Speculators - Perfumes and Embroidery.

I HAVE already mentioned that we arrived at Constantinople during the Ramazan or Lent; and my first anxiety was to pass a day of Fast in the interior of a Turkish family.

This difficult, and in most cases impossible, achievement for an European was rendered easy to me by the fact that, shortly after our landing, I procured an introduction to a respectable Turkish merchant; and I had no sooner written to propose a visit to his harem than I received the most frank and cordial assurances of welcome.

A Greek lady of my acquaintance having offered to accompany me, and to act as my in- 
terpreter, we crossed over to Stamboul, and, after threading several steep and narrow streets, perfectly impassable for carriages, entered the spacious court of the house at which we were expected, and ascended a wide flight of stairs leading to the harem, or women's apartments. The stairs terminated in a large landing-place, of about thirty feet square, into which several rooms opened on each side, screened with curtains of dark cloth embroidered with coloured worsted. An immense mirror filled up a space between two of the doors, and a long passage led from this point to the principal apartment of the harem, to which we were conducted by a black slave.

When I say "we," I of course allude to Mrs. — and myself, as no men, save those of the family and the physician, are ever admitted within the walls of a Turkish harem.

The apartment into which we were ushered was large and warm, richly carpeted, and surrounded on three sides by a sofa, raised about a foot from the ground, and covered with crimson shag; while the cushions, that rested against the wall or were scattered at intervals along the couch, were gaily embroidered with gold thread and coloured silks. In one angle of the sofa stood the tandour: a piece of furniture so unlike any thing in Europe, that I cannot forbear giving a description of it.

vOL. I. 
The tandour is a wooden frame, covered with a couple of wadded coverlets, for such they literally are, that are in their turn overlaid by a third and considerably smaller one of rich silk: within the frame, which is of the height and dimensions of a moderately sized breakfast table, stands a copper vessel, filled with the embers of charcoal; and, on the two sides that do not touch against the sofa, piles of cushions are heaped upon the floor to nearly the same height, for the convenience of those whose rank in the family does not authorize them to take places on the couch.

The double windows, which were all at the upper end of the apartment, were closely latticed; and, at the lower extremity of the room, in an arched recess, stood a classically-shaped clay jar full of water, and a covered goblet in a glass saucer. Along a silken cord, on either side of this niche, were hung a number of napkins, richly worked and fringed with gold ; and a large copy of the Koran was deposited beneath a handkerchief of gold gauze, on a carved rosewood bracket.

In the middle of the floor was placed themangal, a large copper vessel of about a foot in height, resting upon a stand of the same matcrial raised on castors, and filled, like that within the tandour, with charcoal.

The family consisted of the father and mother, 
the son and the son's wife, the daughter and her husband, and a younger and adopted son. The ladies were lying upon cushions, buried up to their necks under the coverings of the tandour; and, as they flung them off to receive us, I was struck with the beauty of the daughter, whose deep blue eyes, and hair of a golden brown, were totally different from what I had expected to find in a Turkish harem. Two glances sufficed to satisfy me that the mother was a shrew, and I had no reason subsequently to revoke my judgment. The son's wife had fine, large, brilliant, black eyes, but her other features were by no means pleasing, although she possessed, in common with all her countrywomen, that soft, white, velvety skin, for which they are indebted to the constant use of the bath. To this luxury, in which many of them daily indulge, must be, however, attributed the fact that their hair, in becoming bright and glossy, loses its strength, and compels them to the adoption of artificial tresses; and these they wear in profusion, wound amid the folds of the embroidered handkerchiefs that they twine about their heads in a most unbecoming manner, and secure by bodkins of diamonds or emeralds, of which ornaments they are inordinately fond.

They all wore chemisettes or under garments of silk gauze, trimmed with fringes of narrow ribbon, and wide trowsers of printed cotton fatl- 
ing to the ancle: their feet were bare, save that occasionally they thrust them into little yellow slippers, that scarcely covered their toes, and in which they moved over the floor with the greatest ease, dragging after them their anterys, or sweeping robes; but more frequently they dispensed with even these, and walked barefoot about the harem. Their upper dresses were of printed cotton of the brightest colours - - that of the daughter had a blue ground, with a yellow pattern, and was trimmed with a fringe of pink and green. These robes, which are made in one piece, are divided at the hip on either side to their extreme length, and are girt about the waist with a cachemire shawl. The costume is completed in winter by a tight vest lined with fur, which is generally of light green or pink.

Their habits are, generally speaking, most luxurious and indolent, if I except their custom of carly rising, which, did they occupy themselves in any useful manner, would be undoubtedly very commendable; but, as they only add, by these means, two or three hours of ennui to each day, I am at a loss how to classify it. Their time is spent in dressing themselves, and varying the position of their ornaments-in the bath - and in sleep, which they appear to have as entirely at their beck as a draught of water; in winter, they have but to nestle under the coverings of the tandour, or in summer to bury 
themselves among their cushions, and in five minutes they are in the land of dreams. Indeed, so extraordinarily are they gifted in this respect, that they not unfrequently engage their guests to take a nap, with the same sang-froid with which a European lady would invite her friends to take a walk. Habits of industry have, however, made their way, in many instances, even into the harem ; the changes without have influenced the pursuits and feeings of the women; and utter idleness has already ceased to be a necessary attribute to the high-bred Turkish female.

As, it was the time of the Ramazan, neither coffee nor sweetmeats were handed to us, though the offer of refreshments was made, which we, however, declined, being resolved to keep Lent with them according to their own fashion. We fasted, therefore, until about half past six o'clock, when the cry of the muezzin from the minarets proclaimed that one of the outwatchers, of whom many are employed for the purpose, had caught a glimpse of the moon. Instantly all were in motion; their preliminary arrangements had been so zealously and carefully made that not another second was lost; and, as a slave announced dinner, we all followed her to a smaller apartment, where the table, if such I may call it, was already laid.

The room was a perfect square, totally un- 
furnished, save that in the centre of the floor was spread a carpet, on which stood a wooden frame, about two feet in height, supporting an immense round plated tray, with the edge slightly raised. In the centre of the tray was placed a capacious white basin, filled with a kind of cold bread soup; and around it were ranged a circle of small porcelain saucers, filled with sliced cheese, anchovies, caviare, and sweetmeats of every description : among these were scattered spoons of box-wood, and goblets of pink and white sherbet, whose rose-scented contents perfumed the apartment. The outer range of the tray was covered with fragments of unleavened bread, torn asunder ; and portions of the Ramazan cake, a dry, close, sickly kind of paste, glazed with the whites of eggs, and strewed over with aniseeds.

Our party was a numerous one - the aged nurse, who had reared the ehildren of the family - the orphan boy of a dead son, who, with his wife, had perished by plague during the previous twelve months-several neighbours who had chosen the hour of dinner to make their visits-a very pretty friend from Scutari-and a very plain acquaintance from the house of death - the widow of a day-whose husband had expired the previous morning, been buried the same evening, and, as it appeared, forgotten on the morrow ; for the "disconsolate widow" had come 
forth in a pink vest, and sky blue trowsers, with rings on her fingers, and jewels in her turban, to seek the advice and assistance of the master of the house, in securing some valuable shawls, and sundry diamonds and baubles which she had possessed before her marriage, from the grasp of the deceased's relatives.

As soon as the serious business of the repast really commenced, that is, when we had each possessed ourselves of a cushion, and squatted down with our feet under us round the dinner tray, having on our laps linen napkins of about two yards in length richly fringed; the room was literally filled with slaves, "black, white, and gray," from nine years old to fifty.

Fish, embedded in rice, followed the side or rather circle sancers that I have already described ; and of most of which I sparingly partook, as the only answer that I was capable of giving to the unceasing " Eat, eat, you are welcome," of the lady of the house. With the fish, the spoons came into play, and all were immersed in the same dish; but I must not omit to add that this custom is rendered less revolting than it would otherwise be, by the fact that each individual is careful, should the plat be partaken of a second time, (a rare occurrence, however, from the rapidity with which they are changed), always to confine herself to one spot. The meat and poultry were eaten with the fingers; each 
individual fishing up, or breaking away, what pleased her eye; and several of them tearing a portion asunder, and handing one of the pieces to me as a courtesy, with which, be it remarked, par parenthèse, I should joyfully have dispensed. Nineteen dishes, of fish, flesh, fowl, pastry, and creams, succeeding each other in the most heterogeneous manner-the salt following the sweet, and the stew preceding the custardwere terminated by a pyramid of pillauf. I had the perseverance to sit out this elaborate culinary exhibition; an exertion which is, however, by no means required of any one, by the observance of Turkish courtesy.

Gastronomy is no science in the East, and gourmands are unknown; the Osmanlis only eat to live, they do not live to eat; and the variety of their dishes originates in a tacit care to provide against individual disgusts, while the extreme rapidity with which they are changed sufficiently demonstrates their want of inclination to indulge individual excess. The women drink only coffee, sherbet, or water; but some few among the men are adopting the vices of civilized nations, and becoming addicted to beverages of a more potent description. No person is expected to remain an instant longer at a Turkish table than suffices him to make his meal ; the instant that an individual has satisfied his appetite, he rises with- 
out comment or apology, washes his hands, and resumes his pipe or his occupation. Nor must I pass over without comment the simple and beautiful hospitality of the Turks, who welcome to their board, be he rich or poor, every countryman who thinks proper to take a seat at it; the emphatic "You are welcome," is never coldly nor grudgingly uttered; and the Mussulmauns extend this unostentatious greeting to each new comer, without reservation or limit, upon the same principle that they never permit them to find fault with any article of food which may be served up. They consider themselves only as the stewards of God, and consequently use the gonds of life as a loan rather than a possession; while they consider themselves bound to give from their superfluity to those who have been less favoured.

As we rose from table, a slave presented herself, holding a basin and strainer of wrought metal, while a second poured tepid water over our hands, from an elegantly-formed vase of the same materials; and a third handed to us embroidered napkins of great beauty, of which I really availed myself with reluctance.

Having performed this agreeable ceremony, we returned to the principal apartment, where our party received an addition in the person of a very pretty old massaljhe, or tale-teller, who had been invited to relieve the tedium of the 
evening with some of her narrations. This custom is very general during the Ramazan, and is a great resource to the Turkish ladies, who can thus recline in luxurious inaction, and have their minds amused without any personal exertion. Coffee was prepared at the mangal, and handed round: after which the elder lady seated herself on a pile of cushions placed upon the floor, and smoked a couple of pipes in perfect silenee, and with extreme gusto, flinging out volumes of smoke, that created a thick mist in the apartment.

I had just begun to indulge in a violent fit of coughing, induced by the density of this artificial atmosphere, when in walked a slave to announce the intended presence of the gentlemen of the family, and in an instant the whole scene was changed. The two Turkish ladies whom I have already mentioned as being on a visit in the house rushed from the room barefooted, in as little time as it would have required for me to disengage myself from the tandour; the less agile massaljhe covered her face with a thick veil, and concealed herself behind the door - the Juno-like daughter (one of the most majestic women I ever remember to have seen, although very far from one of the tallest) flung a handkerchief over her head, and fastened it beneath her chin: while the son's wife caught up a feridjhe, or cloak, and withdrew, muffled amid 
its folds, to her own apartment. The elder lady was the only one of the party undisturbed by the intelligence: she never raised her eyes from the carpet, but continued inhaling the aroma of the "scented weed," gravely grasping her long pipe, her lips pressed against its amber mouth-piece, and her brilliant rings and diamond-studded bracelet flashing in the light.

In a few minutes, the aged father of the family was squatted down immediately opposite to my seat, smothered in furs, and crowned with the most stately looking turban I had yet seen : on one side of him stood a slave with his chibouk, which his wife had just filled and lighted, and on the other his elder son, holding the little brass dish in which the pipe-bowl is deposited to protect the carpet. Near him, on another cushion, lay the tobacco-bag of gold-embroidered cachemire, from which the said son was about to regale himself, after having supplied the wants of his father: and a few paces nearer to the door reclined the handsome Soliman Effendi, the adopted son to whom I have already alluded.

While the party were refreshing themselves with coffee, which was shortly afterwards served to them, a cry from the minarets of a neighbouring mosque announced the hour of prayer ; when the old man gravely laid aside his pipe, and, spreading a crimson rug above the carpet near the spot where he had been sitting, turned 
his face to the East, and began his devotions by stroking down his beard and falling upon his knees, or rather squatting himself in a doubledup position which it were impossible to describe. For a while his lips moved rapidly, though not a sound escaped them, and then suddenly he prostrated himself three times, and pressed his forehead to the carpet, rose, and folding his arms upon his breast, continued his prayer-resumed after a brief space his original position, rocking his body slowly to and fro-again bent down and, repeated the whole of these ceremonies three times, concluding his orison by extending his open palms towards Heaven; after which, he once more slowly and reverentially passed his hand down his beard, and, without uttering a syllable, returned to his seat and his pipe, while a slave folded the rug and laid it aside. I remarked that at intervals, during the prayer, he threw out a long respiration, as though he had been collecting his breath for several seconds ere he suffered it to escape, but throughout the whole time not a single word was audible. The rest of the party continued to laugh, chat, and smoke quite unconcernedly, however, during the devotions of the master of the house, who appeared so thoroughly absorbed as to be utterly unconscious of all that was going on around him.

I ought not to have omitted to mention that, on entering the harem, each of the gentlemen of the 
family had deposited on a table at the extremity of the apartment his evening offering; for no 'Turk, however high his rank, returns home for the night, when the avocations of the day are over, empty-handed: it signifies not how trifling may be the value of his burthen - a cluster of grapes-a paper of sweetmeats - or, among the lower orders, a few small fish, or a head of salad - every individual is bound to make an offering to the Dei Penates; and to fail in this duty is to imply that he is about to repudiate his wife.

The father of the eldest son, Usuf Effendi, had brought home Ramazan cakes, but Soliman Effendi deposited on the tandour a bolsha, or handkerchief of clear muslin wrought with gold threads, and containing sweetmeats; among them were a quantity of Barcelona nuts, which, in Turkey, are shelled, slightly dried in the oven, and eaten with raisins, as almonds are in Europe. In the course of the evening, the elder lady resumed her place at the tandour; and, in the intervals of the conversation, she amused herself by burning one of the nuts at a candle, and, having reduced it to a black and oily substance with great care and patience, she took up a small round hand-mirror, set into a framework of purple velvet, embroidered in silver that was buried among her cushions, and began to stain her eyebrows, making them meet over 
the nose, and shaping them with an art which nothing but long practice could have enabled her to acquire.

Their questions were of the most puerile description - my age - why I did not marry whether I liked Constantinople-if I could read and write, \&c., \&c.; but no impertinent comment on fashions and habits so different from their own escaped them : on the contrary, they were continually remarking how much I must find every thing in Turkey inferior to what $I$ had been accustomed to in Europe: and they lost themselves in wonder at the resolution that had decided me to visit a part of the world where I must suffer so many privations. Of course, I replied as politely as I could to these complimentary comments; and my companion and myself being much fatigued with the exertions that we had made during the day, we determined to retire to our apartment, without waiting to partake of the second repast, which is served up between two and three o'clock in the morning.

From this period the Turks remain smoking, and sipping their coffee, detailing news, and telling stories, an amusement to which they are extremely partial, until there is sufficient light to enable them to distinguish between a black thread and a white onc, when the fast is scrupulously resumed. But it may be curious to remark, that, as not even a draught 
of water can be taken until the evening meal, and, (still greater privation to the Osmanli,) not a pipe can be smoked, they have adopted a singular expedient for appeasing the cravings of re-awakening appetite. They cause opium pills to be prepared, enveloped in one, two, and three coatings of gold leaf ; and these they swallow at the last moment when food is permitted to be taken; under the impression that each will produce its intended effect at a given time, which is determined by the number of envelopes that have to disengage themselves from the drug before it can act.

The apartment wherein we passed the night was spacious and lofty; and the ceiling was lined with canvass, on which a large tree in full leaf was painted in oils; and, as this was the great ornament of the room, and, moreover, considered as a model of ingenious invention, one of the slaves did not fail to point out to us that the canvass, instead of being tightly stretched, was mounted loosely on a slight frame, which, when the air entered from the open windows, permitted an undulation intended to give to the tree the effect of reality. I do not think that I was ever more amused - for the branches resembled huge boa constrictors much more than any thing connected with the vegetable kingdom: and every leaf was as large and as black as the crown of a man's hat. 
Our beds were composed of mattresses laid one above the other upon the floor, and these were of the most costly description ; mine being yellow satin brocaded with gold, and that of my companion violet-coloured velvet, richly fringed. A Turkish bed is arranged in an instant-the mattresses are covered with a sheet of silk gauze, or striped muslin, (my own on this occasion was of the former material)-half a dozen pillows of various forms and sizes are heaped up at the head, all in richly embroidered muslin cases, through which the satin containing the down is distinctly seen - and a couple of wadded coverlets are laid at the feet, carcfully folded : no second sheet is considered necessary, as the coverlets are lined with fine white linen. Those which were provided for us were of pale blue silk, worked with rose-coloured flowers.

At the lower end of every Turkish room are large closets for the reception of the beciding; and the slaves no sooner ascertain that you have risen, than half a dozen of them enter the apartment, and in five minutes every vestige of your couch has disappeared-you hurry from the bed to the bath, whence you cannot possibly escape in less than two hours - and the business of the day is then generally terminated for a Turkish lady. All that remains to be done is to sit under the covering of the tandour, passing the beads of a perfumed chaplet rapidly through the fingers 
- arranging and re-arranging the head-dress and ornaments - or to put on the yashmac and feridjhe, and sally forth, accompanied by two or three slaves, to pay visits to favourite friends; either on foot, in yellow boots reaching up to the swell of the leg, over which a slipper of the same colour is worn; or in an araba, or carriage of the country, all paint, gilding, and crimson cloth, nestled among cushions, and making more use of her eyes than any being on earth save a Turkish woman would, with the best inclination in the world, be able to accomplish ; such finished coquetry I never before witnessed as that of the Turkish ladies in the street. As the araba moves slowly along, the feridjhe is flung back to display its white silk lining and bullion tassels; and, should a group of handsome men be clustered on the pathway, that instant is accidentally chosen for arranging the yashmac. 'The dark-eyed dames of Spain, accomplished as they are in the art, never made more use of the graceful veil than do the orientals of the jealous yashmac.

The taste for "shopping"-what an excellent essay might the "piquante and spirituelle Lady Morgan write on this universal feminine mania! -is as great among the eastern ladies as with their fair European sisters; but it is indulged in a totally different manner. Constantinople boasts no commercial palace like those of Howell

VOL. I. 
and James, or Storr and Mortimer ; and still less a Maradan Carson: no carriage draws up at the door of an Ebers or a Sams for " the last new novel ;" nor does a well-warmed and wellfloored bazar tempt the satin-slippered dame to wander among avenues of glittering gewgaws and elaborated trifles: the carriage of the veiled Osmanli stops at the door of some merchant who has a handsome shopman; and the name of the latter, having been previously ascertained, Sadak or Mustapha, as the case may be, is ordered by the arabajhe, or coachman, to exhibit to his mistress some article of merchandize, which he brings accordingly, and, while the lady affects to examine its quality and to decide on its value, she enters into conversation with the youth, playing upon him meanwhile the whole artillery of her fine eyes. The questioning generally runs nearly thus:- "What is your name?" - "How old are you?"- "Are you married?" - "Were you ever in love?"-and similar misplaced and childish questions. Should the replies of the interrogated person amuse her, and his beauty appear as great on a nearer view as when seen from a distance, the merchandize is objected to, and the visit repeated frequently, ere the fastidious taste of the purchaser can be satisfied.

Nor are women of high rank exempt from this indelicate fancy, which can only be accounted for by the belief that, like caged birds 
occasionally set free, they do not know how to use their liberty: the Sultana Haybétoullah, sister to his Sublime Highness, the Light of the Ottoman Empire, is particularly attached to this extraordinary passe-temps.

The following morning we started on an exploring expedition, accompanied by the closelyveiled and heavily-draped "Juno," and attended by her nurse and child, and her quaintly-habited footman; and, as the carriage could not approach the house by a considerable distance, owing to the narrowness and steepness of the streets in that quarter of the city, (which, built upon the crest and down the slope of one of the "seven hills," overlooks the glittering and craft-clustered port), we were obliged to walk to it through the frozen snow, upon the same principle that, as the mountain would not go to Mahomet, Mahomet was compclled to go to the mountain.

Directly I cast my eyes on the carriage, I had an excellent idea of that which the fairy godmother of Cinderella created for her favourite out of a pumpkin. Its form was that of a small covered waggon; its extcrior was all crimson cloth, blue silk fringe, and tassels; and its inside precisely resembled a cake of gilt gingerbread. Four round looking-glasses, just sufficiently large to reflect the features, were impannelled on either side of the doors; and in the place of windows we had gilt lattices, so closely made 
that our position was the very reverse of cheerful ; and, as I found it, moreover, quite impossible to breathe frecly, these lattices were flung back despite the cold, and this arrangement being made, I established myself very comfortably on the satin cushions, with my feet doubled under me à la Turque, amid the piled-up luxuries of duvet and embroidery.

Our first visit was to the charshees, or, as Europeans for some inexplicable reason have the habit of calling them, the "bazars" - the word bazar literally signifying market-and, as the carriage rattled under the heavy portal, my first feeling was that of extreme disappointment. The great attraction of these establishments is undeniably their vast extent, for in tenue and richness they are as inferior to our own miniature bazars in London as possible. Rudely paved-disagreeably dirty-plentifully furnished with égouts, of which both the sight and the scent are unpleasing-badly lightedclumsily built-and so constructed as to afford no idea of the space they cover, until you have wandered through the whole of their mazes, your involuntary impression is one of wonder at the hyperboles which have been lavished on them by travellers, and the uncalled-for extacies of tourwriters.

The charshees are like a little commercial town, roofed in ; each street being appropriated 
to one particular trade or calling; and presenting relative degrees of attraction and luxury, from the diamond-merchant's counter to the cushions of the shawl and fur-menders.

The Beizensteen is wonderfully rich in jewels, but in order to witness the display of these you must be, or be likely to become, a purchaser, as only a few, and those of comparatively small value, are exposed in the glass cases which ornament the counters. Nearly the whole of the jewellers are Armenians; as well as the money-changers, who transact business in their immediate vicinity. Indeed, all the steady commerce on a great scale in the capital may be said to be, with very slight exceptions, in the hands of the Armenians, who have the true, patient, plodding, calculating spirit of trade ; while the wilder speculations of hazardous and ambitious enterprise are grasped with avidity by the more daring and adventurous Greeks; and hence arises the fact, for which it is at first sight difficult to account, that the most wealthy and the most needy of the merchants of Stamboul are alike of that nation: while you rarely sec an Armenian either limited in his means, or obtrusive in his style.

In the street of the embroiderers, whose stalls make a very gay appearance, being hung all over with tobacco-bags, purses, and coiffires, wrought in gold and silver, we purchased a couple of richly-worked handkerchiefs, used by 
the ladies of the country for binding up the hair after the bath, and which are embroidered with a taste and skill truly admirable.

Thence we drove to the shoe bazar, where slippers worked with seedpearls, and silver and gold thread, upon velvets of every shade and colour, make a very handsome and tempting appearance; and among these are ranged circular looking-glasses, of which the frames, backs, and handles are similarly ornamented. The scentdealers next claimed our attention, and their quarter is indeed a miniature embodiment of "Araby the Blest," for the atmosphere is one cloud of perfume. Here we were fully enabled to understand l'embarras des richesses, for all the sweets of the East and West tempted us at once, from the long and slender flacon of Eau de Cologne, to the small, gilded, closely-enveloped bottle of attar-gul. Nor less luxurious was the atmosphere of the spice bazar, with its pyramids of cloves, its piles of cinnamon, and its bags of mace-and, while the porcelain dealers allured us into their neighbourhood by a dazzling display, comprising every variety of ancient and modern china; silks, velvets, Broussa satins, and gold gauze in their turn invited us in another direction - and, in short, I left the charshees with aching eyes, and a very confused impression of this great mart of luxury and expence.

It was a most fatiguing day; and I was 
scarcely sorry when, having bade farewell to the hospitable family, who had so kindly and courteously received us as guests, we hastened to embark on board our caïque, and in ten minutes found ourselves at Topp-hanne, whence we slowly mounted the steep ascent which terminates in the high-street of Pera, within a hundred yards of our temporary residence. 


\section{CHAP'TER III.}

Turning Dervishes - Appearance of the Tekiè - The Mausoleum Duties of the Dervishes.-Chapel of the Convent - The Chief Priest -Dress of the Brotherhood-Melancholy Music-Solemnity of the Service-Mistakes of a Modern Traveller-Explanation of the Ceremony-The Prayer-The Kiss of Peace-Appearance of the Chapel - Religions Tolerance of the Turks - The French Renegade Sketch of Halet Effendi, the Founder of the Tekiè.

I PAID two visits to the convent (if such, indeed, it may be termed) of Turning, or, as they are commonly called in Europe, Dancing Dervishes, which is situated opposite the Petit Champs des Morts, descending towards Galata. The court of the Tekiè is entered by a handsomely ornamented gate, and, having passed it, you have the cemetery of the brethren on your left hand, and the gable of the main building on your right. As you arrive in front of the convent, the court widens, and in the midst stands a magnificent plane tree of great antiquity, carefully railed in; while you have on one side the elegant mausoleum in which repose the superiors of the order: and on the other the fountain of white marble, roofed in like an oratory, and enclosed on all its six sides from the weather, where the Dervishes perform their 
ablutions ere they enter the chapel. The mausoleum is of the octagon form, the floor being raised two steps in the centre, leaving a space all round, just sufficiently wide for one person to pass along. 'The sarcophagi are covered with plain clay-coloured cloth, and at the head of each tomb is placed the geulaf, or Dervishes' hat, encircled by a clear muslin handkerchief, embroidered with tinted silks and gold thread. A large gilt frame, enclosing the representation of a hat wrought in needlework, and standing on a slab, on which is inscribed a sentence from the Koran, rests against one of the sarcophagi, and huge wax-candles in plain clay-coloured candlesticks are scattered among the tombs.

The Tekiè is a handsome building with projecting wings, in which the community live very comfortably with their wives and children ; and whence, having performed their religious duties, they sally forth to their several avocations in the city, and mingle with their fellow-men upon equal terms. Unlike the monks of the church of Rome, the Dervishes are forbidden to accunulate wealth in order to enrich either themselves or their convent. The most simple fare, the least costly garments, serve alike for their own use, and for that of their families: industry, temperance, and devotion are their duties ; and, as they are at liberty to secede from their selfimposed obligations whenever they see fit to do 
so, there is no lukewarmness among the community, who find time throughout the whole year to devote many hours to God, even of their most busy days ; and, unlike their fellow-citizens, the other Mussulmauns, they throw open thedoors of their chapel to strangers, only stipulating that gentlemen shall put off their shoes ere they enter.

This chapel, which has been erroneously designated a "mosque," is an octagon building of moderate size, neatly painted in fresco. The centre of the floor is railed off, and the enclosure is sacred to the brotherhood; while the outer circle, covered with Indian matting, is appropriated to visiters. A deep gallery runs round six sides of the building, and beneath it, on your left hand as you enter, you remark the lattices through which the Turkish women witness the service. A narrow mat surrounds the circle within the railing, and upon this the brethren kneel during the prayers; while the centre of the floor is so highly polished by the perpetual friction that it resembles a mirror, and the boards are united by nails with heads as large as a shilling, to prevent accidents to the feet of the Dervishes during their evolutions. A bar of iron descends octagonally from the centre of the domed roof, to which transverse bars are attached, bearing a vast number of glass lamps of different colours and sizes ; and, against many of the pillars, of which 1 counted four-and-twenty, 
supporting the dome, are hung frames, within which are inscribed passages from the Prophets.

Above the seat of the superior, the name of the founder of the Tekie is written in gold on a black ground, in immense characters. This seat consists of a small carpet, above which is spread a crimson rug, and on this the worthy principal was squatted when we entered, in an ample cloak of Spanish brown, with large hanging sleeves, and his geulaf, or high hat of grey felt, encircled with a green shawl. I pitied him that his back was turned towards the glorious Bosphorus, that was distinctly seen through the four large windows at the extremity of the chapel, flashing in the light, with the slender minarets and lordly mosques of Stamboul gleaming out in the distance.

One by one, the Dervishes entered the chapel, bowing profoundly at the little gate of the enclosure, took their places on the mat, and, bending down, reverently kissed the ground; and then, folding their arms meckly on their breasts, remained buried in prayer, with their eyes closed, and their bodies swinging slowly to and fro. They were all enveloped in wide cloaks of dark coloured cloth with pendent sleeves; and wore their geulafs, which they retained during the whole of the service.

I confess that the impression produced on my mind by the idea of Dancing Dervishes was 
the very reverse of solemn; and I was, in consequence, quite unprepared for the effect that the exhibition of their religious rites cannot fail to exert on all those who are not predetermined to find food for mirth in every sectarian peculiarity. The deep stillness, broken only by the breath of prayer, or the melancholy wailing of the muffled instruments, which seemed to send forth their voice of sadness from behind a cloud in subdued sorrowing, like the melodious plaint of angels over fallen mortality - the concentrated and pious self-forgetfulness of the community, who never once cast their eyes over the crowds that thronged their chapel - the deep, rich chant of the choral brethren - even the very contrast afforded by the light and fairylike temple in which they thus meekly ministered to their Maker, with their own calm and inspired appearance, heightened the effect of the scene; and tacitly rebuked the presumption and worldliness of spirit that would have sought a jest in the very sanctuary of religion.

The service commenced with an extemporaneous prayer from the chief priest, to which the attendant Dervishes listened with arms folded upon their breasts, and their eyes fixed on the ground. At its conclusion, all bowed their forcheads to the earth; and the orchestra struck into one of those peculiarly wild and melancholy 'Turkish airs which are unlike any other 
music that I ever heard. Instantly, the full voices of the brethren joined in chorus, and the effect was thrilling: now the sounds died away like the exhausted breath of a departing spirit, and suddenly they swelled once more into a deep and powerful diapason that seemed scarce earthly. A second stillness of about a minute succeeded, when the low, solemn music was resumed, and the Dervishes, slowly rising from the earth, followed their superior three times round the enclosure; bowing down twice under the shadow of the name of their Founder, suspended above the seat of the high priest. This reverence was performed without removing their folded arms from their breasts - the first time on the side by which they approached, and afterwards on that opposite, which they gained by slowly revolving on the right foot, in such a manner as to prevent their turning their backs towards the inscription. The procession was closed by a second prostration, after which, each Dervish having gained his place, cast off his cloak, and such as had walked in woollen slippers withdrew them, and, passing solemnly before the Chief Priest, they commenced their evolutions.

I am by no means prepared, nor even inclined, to attempt a Quixotic defence of the very extraordinary and bizarre ceremonial to which I was next a witness; but I cannot, nevertheless, 
agree with a modern traveller in describing it as "an absurdity." That it does not accord with our European ideas of consistent and worthy worship is not only possible, but certain; yet I should imagine that no one could feel other than respect for men of irreproachable character, serving God according to their means of judgment.

The extraordinary ceremony which gives its name to the Dancing, or, as they are really and much more appropriately called, the Turning Dervishes - for nothing can be more utterly unlike dancing than their evolutions - is not without its meaning. The community first pray for pardon of their past sins, and the amendment of their future lives; and then, after a silent supplication for strength to work out the change, they figure, by their peculiar and fatiguing movements, their anxiety to "shake the dust from their feet," and to cast from them all worldly ties.

As I could not reconcile myself to believe that the custom could have grown out of mere whim, I took some pains to ascertain its meaning, as well as visiting the chapel a second time during its observance, in order to ascertain whether the ceremonies differed on different days, but I remarked no change.

Immediately after passing with a solemn reverence, twice performed, the place of the High 
Priest, who remained standing, the Dervishes spread their arms, and commenced their revolving motion; the palm of the right hand being held upwards, and that of the left turned down. Their under-dresses (for, as I before remarked, they had laid aside their cloaks) consisted of a jacket and petticoat of dark coloured cloth, that descended to their feet; the higher order of brethren being clad in green, and the others in brown, or a sort of yellowish gray; about their waists they wore wide girdles, edged with red, to which the right side of the jacket was closely fastened, while the left hung loose : their petticoats were of immense width, and laid in large plaits beneath the girdle, and, as the wearers swung round, formed a bell-like appearance; these latter garments, however, are only worn during the ceremony, and are exchanged in summer for white ones of lighter material.

The number of those who were "on duty," for I know not how else to express it, was nine; seven of them being men, and the remaining two, mere boys, the youngest certainly not more than ten years of age. Nine, eleven, and thirteen are the mystic numbers, which, however great the strength of community, are never exceeded; and the remaining members of the brotherhood, during the evolutions of their companions, continue engaged in prayer within the enclosure. 'These on this occasion amounted to about a score, 
and remained each leaning against a pillar: while the beat of the drum in the gallery marked the time to which the revolving Dervishes moved, and the effect was singular to a degree that baffles description. So true and unerring were their motions, that, although the space which they occupied was somewhat circumscribed, they never once gained upon each other: and for five minutes they continued twirling round and round, as though impelled by machinery, their pale, passionless countenances perfectly inmobile, their heads slightly declined towards the right shoulder, and their inflated garments creating a cold, sharp air in the chapel, from the rapidity of their action. At the termination of that period, the name of the Prophet occurred in the chant, which had been unintermitted in the gallery; and, as they simultaneously paused, and, folding their hands upon their breasts, bent down in reverence at the sound, their ample garments wound about them at the sudden check, and gave them, for a moment, the appearance of mummies.

An interval of prayer followed; and the same ceremony was performed three times; at the termination of which they all fell prostrate on the earth, when those who had hitherto remained spectators flung their cloaks over them, and the one who knelt on the left of the Chief Priest rose, and delivered a long prayer divided into 
sections, with a rapid and solemn voice, prolonging the last word of each sentence by the utterance of "ha-ha-ha" - with a rich depth of octave that would not have disgraced Phillips.

This prayer was for "the great ones of the earth" - the magnates of the land- all who were " in authority over them;" and at each proud name they bowed their heads upon their breasts, until that of the Sultan was mentioned, when they once more fell flat upon the ground, to the sound of the most awful howl I ever heard.

This outburst from the gallery terminated the labours of the orchestra; and the superior, rising to his knees while the others continued prostrate, in his turn prayed for a few instants ; and then, taking his stand upon the crimson rug, they approached him one by one, and, clasping his hand, pressed it to their lips and forehead. When the first had passed, he stationed himself on the right of the superior, and awaited the arrival of the second, who, on reaching him, bestowed on him also the kiss of peace, which he had just proffered to the Chief Priest; and each in succession performed the same ceremony to all those who had preceded him, which was acknowledged by gently stroking down the beard.

This was the final act of the exhibition; and, the superior having slowly and silently traversed the enclosure, in five scconds the chapel was

VOL. I.

F。 
empty, and the congregation busied at the portal in reclaiming their boots, shoes, and slippers.

I had never hitherto seen such picturesque groups as those which thronged the Dervishes' chapel on my second visit; nor did I ever witness more perfect order in any public assembly. A deep stillness reigned throughout the whole ceremony, only broken by the sobs of a middle-aged Turk who stood near me, and who was so much overcome by the saddening wail of the orchestra that he could not restrain his tears; a circumstance by no means uncommon in this country, where all ranks are peculiarly susceptible to the influence of music.

The interior of the edifice was a perfect picture, of which the soberly-clad Dervishes occupied the centre; while the exterior circle was peopled with groups of soldiers in their coarse wrapping coats and red caps-venerable Turks in claret-coloured pelisses, richly furred - descendants of Mahomet, with their green turbans and portly beards - and peasants in their rude suits of dusky brown; all equally intent, and all equally orderly.

The Turks are extremely tolerant with regard to religious opinions; their creed being split into as many sects as that of the Church of England; and each individual being left equally free to follow, as he sees fit, the dictates of his conscience. The Dervishes are of several different 
orders. The Mivlavies are materialists in their faith ; the Zerrins worship the Virgin Mary ; and the Bektachis believe in the Saviour and the twelve apostles; every order has its peculiar constitution, differing from the dogmas of simple Islamism; but they are universally venerated by Musselmauns, despite their sectarian prejudices. They are generally versed in astrology and music; exorcise sufferers from witchcraft and the evil eye ; and are always of quiet and submissive manners, never mingling either in the intrigues of the court, or the cabals of the Ulemas.

It is not surprising that the Turks should venerate their own Dervishes, when they not only tolerate but even respect the Christian monks, and regard their monasteries as holy places, bearing the names of saints, and inhabited by men wholly devoted to God. To such a height, indeed, do they carry this reverence, that they permit the communities of several convents built on the charming little group of islands, called "Princes' Islands," situated in the Propontis, not more than two leagues from Constantinople, to be summoned to their chapel to prayer by the ringing of bells; a privilege which is not accorded to any Christian church devoted to a general congregation; but perhaps the greatest proof that can be adduced of their veneration for religious societies exists in the fact that in the mausoleum of the principal 
Tekiè at Iconium lies one of the most celebrated of Musselmaun saints, Mollah Hunkiar, and beside him a Christian monk, to whom he had been so tenderly attached during his life, that he desired in his will that they should not be separated after death. The two tombs still exist, and what renders the anecdote still more worthy of record, is the circumstance that it is the Cheik or Abbot of this very monastery, who has the privilege of girding on the sword of the Sultan in the Mosque of Eyoub, on his accession to the ()ttoman throne.

The Turks do not consider their women worthy to become Dervishes, but they, nevertheless, respect the Christian nuns ; and a somewhat curious proof of this fact was given in 1818, on the receipt by the Sultan and his favourite minister, Halet Effendi, of two petitions drawn up by a sisterhood at Genoa, in which were set forth the injuries done to their convent by the French Republicans, terminating with a prayer to " his very pious Highness," to send to them, as a present, three Turkey carpets to cover the floor of their chapel, one of which was to be crimson, a second purple, and the third green; and in return they promised to pray for the health, prosperity, and glory of the august head of the Ottoman Empire. 'The Sultan gallantly acceded to their request, and the compatriotes of Roxalana received with the least 
possible delay the magnificent donation by which a Musselmaun Emperor contributed to the adornment of a temple dedicated to Christian worship.

In the cemetery of the Tekiè at Pera lies the body of the Marquis de Bonneval, a French renegade who died a pasha; and the stone slab yet remains there that once covered the head of Halet Effendi, the founder of the convent, which, I have omitted to mention, is built entirely of marble. The head of the Effendi has, however, been removed to a less sacred place of burial, and has found a traitor's grave.

Halet Effendi, once the favourite of the Sultan, was the cause of the Greek insurrection, which he brought about to conceal his own disloyal views. Having, by his intrigues, caused the appointment of Michel Suzzo to the principality of Moldavia, and having been reproached with the disaffection of Suzzo towards his Imperial master, the minister, who was responsible for the conduct and loyalty of his Greek protégé, boldly replied that the disaffection towards the Sultan was not that of Suzzo individually. but of his whole nation; an assertion which he immediately proceeded to bear out by exciting the Greeks covertly to rebellion; and he was so well seconded by his creature that, when Ypsalanti reared his standard in the provinces, Suzzo joined his banner, and the insurrection in the 
Morea, and the revolt of the Greeks in Constantinople, with the murder of the Patriarch, were the fearful consequences of the rebellious coalition; a treason which Mahmoud visited on his favourite with a sentence of exile to Iconia, giving him, at the same time, an autograph letter, in which he pledged himself to respect both his life and property; but, after the lapse of a few years, repenting an act of clemency so misplaced, the Sultan dispatched a Capedjeebasha, furnished with a Firman of recall, to his banished courtier, who found Halet Effendi at Iconia, and presented his credentials. The exile, overjoyed at so sudden and unlooked-for a change in his fortunes, lost no time in preparing for his return to Constantinople ; but he had not long confided himself to the keeping of the Capedjee-basha when the bow-string terminated his existence, and the executioner hastened back to Stamboul, carrying along with him the head of his victim.

'This ghastly memorial of their benefactor was consigned, at their urgent request, to the Dervishes of Pera, who buried it in their grave-yard, beneath the small slab of stone, which, in a 'Turkish cemetery, indicates to the initiated that the deceased above whom it is placed has perished by violence; but it had not lain there more than a few days, when the Sultan chanced to inquire how it had been disposed of; and, hear- 
ing that it had received burial at this Tekiè, of whose order, entitled Mevlavies, he is himself a member, (and whose chapel in which he formerly performed his evolutions he still frequents, although in private, occupying, on his visits, one of the latticed closets.) he ordered that it should be immediately disinterred and carried to Balata, where the common sewers of the city empty themselves into the Bosphorus. This was accordingly done; and the turban-crested pillar that surmounts the slab now only serves to indicate the spot where rested for a few brief days the dishonoured head of Halet Effendi. 


\section{CHAPTER IV.}

Merchants of Galata-Palaces of Pera-Picturesque style of BuildiugThe Perotes-Social Subjects - Greeks, European and SchismaticAmbassadorial Residences-Entrée of the Embassies-The Carnival -Soirées Dansantes-The Austrian Minister-Madame la Baronne -The Russian Minister-Madame de Boutenieff-The Masked Ball -Russian Supremacy - The Prussian Plenipotentiary - The Sardinian Chargé d'Affaires-Diplomacy Unhoused-Society of Pera.

Neituer Frank nor Christian is allowed to inhabit the "City of the Faithful;" and the faubourg of Pera, situated on the opposite side of the port, is consequently the head-quarters of the élite of European society. Galata, which skirts the shore of the Bosphorus at the base of the hill on which Pera is built, numbers among its inhabitants many very respectable merchants, whose avocations demand their continual presence; but Pera is the dwelling-place of the beau-monde - the seat of fashion - the St. James's of the capital. Here every thing social is en magnifique : the residences attached to the different Legations glory in the imposing designations of "palaces" - the gloomy magazins of the Parisian modistes are as dear and as dirty as can be desired - all the employés of diplomacy throng the narrow, steep, and ill- 
paved streets, while the fair Greeks look down upon them from their bay-windows, projecting far beyond the façade of the building; and the bright-eyed Armenians peer from their lattices " all-seeing, but unseen." The quaintly-coloured houses, looking like tenements of painted pasteboard, appear as though a touch would make them meet, and are picturesque beyond description, as they advance and recede, setting all external order, regularity, and proportion, at defiance.

In my rapid definition of European society, I must not omit to mention that the Perotes, or natives of Pera, consider themselves as much Franks as though they had been born and nurtured on the banks of the Thames or the Seine; and your expression of amusement at this very original notion would inevitably give great offence. Conceding this point, therefore, as one which will not admit of argument, I shall simply divide society into two parts - the diplomatic and the scandalous - premising, however, that it requires a delicate touch to separate them, they are so intimately interwoven. Those who have the entrée of the several embassies criticise each other; while those who have not, exercise a still more powerful prerogative; and certain it is that, between the two, the population of Pera is a great circulating medium which would rencler an official "hue and cry" a work of su- 
pererogation. "Not a feather falls to the ground," but in half an hour every individual in the place knows by whom it was plucked, and the tale is told with a raciness and a zest that would make the fortune of a Sunday paper.

A nice distinction exists among the Greeks, on which they vehemently insist; the Greek Catholics consider themselves as Europeans, while the schismatic Greeks do not assume this privilege, of which the former are extremely jealous.

After the residence of a few weeks, you can readily determine the origin of every female whom you encounter in the streets of Pera. The fair Perotes, indeed, wear the bonnet, the cloak, and the shawl, which form the walking garb of the genuine European gentlewoman; but, nevertheless, it is impossible not to distinguish them at a glance; an insurmountable taste for bright colours, an indescribable peculiarity in the adjustment of their toilette, at once mark the Perote; while the dark-eyed Greek is known by her wide-spreading turban of gauze or velvet, over which is flung a lace veil, which, falling low upon the back and shoulders, leaves the face almost entirely uncovered.

Since the great fire of Pera, the Ambassadors of England and France have resided at Therapia, a pretty village on the banks of the Bosphorus, near the mouth of the Black Sea; but the Inter. 
nuncio of Russia, the Ministers of Austria and Prussia, and the Chargés d'Affaires of Sardinia and Holland, still inhabit the town during the winter months. 'The Austrian palace, however, is the only one that now remains, the other diplomatic establishments being compressed into dwelling-houses; thus the Russian minister inhabits a mansion in the High Street, and the Dutch Chargé d'Affaires resides next door to us.

The entrée of the embassies is peculiarly easy to the resident Europeans, as their number is so limited that les grands convenances are almost necessarily laid aside, and their Excellencies super-eminently tolerant with regard to the rank of their guests. Thus it is somewhat startling to a traveller; accustomed to the exclusive circles of Paris and London, to find, not only merchants and their wives at the diplomatic soirées, but even the head clerks and their fair partners. It is true that the mode of reception has gradations of graciousness,

"Small by degrees, and beantifully less;"

but this is mere matter of individual feeling. and power of endurance-the fact remains unaltered.

The Carnival had this year resumed its gaiety ; men's minds had begun to cast off the panic occasioned by the terrific conflagration which almost made the town a waste, and nearly ruined 
many of the inhabitants whose property consisted chiefly in houses.

At the Austrian palace there were balls every Sunday throughout the Carnival, where mustachioes and diplomatic buttons were rife. The never-ending cotillon, the rapid mazurka, the quadrille, and waltz, were equally popular; and I have danced the first with a Greek, the second with a Russian, the third with a Frenchman, and the fourth with a German, during the course of the evening.

The Baron de Stürmer, the Austrian minister, is about fifty years of age, partially bald, and remarkably grave-looking when not excited; but his address is peculiarly agreeable, and his smile like lightning.

Madame la Baronne is a good specimen of the present school of Parisian breeding-her pride is blent with playfulness, and her courtesy is as gracious as it is graceful. Although tant soit peu precieuse - she is perfectly free from pedantry, and is a delightful conversationist. She has memories of Napoleon at St. Helena, where she resided for several years; anecdotes, piquantes and political-those well-worded and softly-articulated compliments which seat you upon velvet; and, above all, that air of genuine laissez aller insouciance which no woman save a Parisian ever thoroughly acquires. I am indebted to the elegant hospitality of this lady for many of the 
most pleasant hours that I spent in the Frank circle at Pera.

M. de Boutenieff, the Russian minister, has a face which, for the first five minutes, baffles you by its contradictory expression - there is a character of benevolence and gentleness about the forehead and eyes that attracts, while the subtle curve of the lip repulses by its cast of craft and caution - his conversation is easy, courtly, and pleasing ; and his unremitted good humour and affability render him universally popular in society. Madame de Boutenieff, who is his second wife, is young, graceful, and lively - an indefatigable dancer, and a fascinating hostess ; and, moreover, the niece of Nesselrode.

The soirées dansantes at the Russian palace terminated with a masked ball, which worthily wound up the Carnival, and was sustained with great spirit. The fair hostess herself, with two ladies attached to the legation, and the wife of the French chancellor, personated angels, who were led into the ball-room by a parti carré of devils, embodied by four of the Russian secretaries. Some of our politicians will assuredly smile at the conceit, nor can I forebear to admit the propriety of the fancy ; for truly, when I consider the number of attachés to the Russian Legation, as compared with that of the other powers at this court, I am inclined to allow that "their name is legion." 
Even in a ball-room the Russian supremacy is palpably evident-their number, their political power, their never-ceasing efforts at popularity-cannot be forgotten for a moment. There is diplomacy in every action-in every lookin every tone - and withal a self-gratulatory, quiet species of at-home-ness every where and with everybody, which shews you at once that they are quite at ease, at least, for the present.

Exquisite, in the most wide acceptation of the term, in their costume - affectedly refined and aristocratic in their manners - acharnés pour la danse - "passant la moitié de leur temps a rien faire, et l'autre moitié à faire des riens," the attachés of M.de Boutenieff, upwards of thirty in number, are as busily employed in turning heads and winning hearts, as though the great stake which they came here to play were but the secondary object of their mission.

Count Königsmark, the Prussian minister, is a high-bred and accomplished gentleman : distinguished by that calm and graceful tenue that sits so well on men of rank, and which is the most becoming attribute alike of mental and of social aristocracy.

The Sardinian Chargé d'Affaires, General Montiglio, is of very retiring habits, and mixes little in general society; but he is a person of considerable acquirements, and an indefatigable sportsman. His domestic history is a little 
romance, and may serve to account in a great measure for his love of retirement, and the hermit-like seclusion of his wife. Having made a mariage d'inclination which was considered by the Sardinian court to be incompatible with his rank and position in society, he was sent into honourable exile to Smyrna, as Chargé d'Affaires, whence he was a short time since removed to Constantinople; where, as I before remarked, he is rarely met with amid the Perote crowd that fills the ambassadorial ball-rooms.

The other foreign ministers play a comparatively insignificant rôle in socicty; as, since the destruction of the several diplomatic residences in the great fire, they have been compelled to inhabit houses which are not calculated for reception; and it would appear as though they are likely to be long situated thus: the only palace in process of restoration being that of Russia. Here again is asserted the autocracy of the North-the English palace is in ruins, and parasites are wreathing, like emeraldcoloured snakes, about its tottering walls Holland, France, all save Austria, are

"Driven from their parch'd and blacken'd halls."

The evil is general - but the remedy has been applied, as yet, only in one instance.

Close the doors of the diplomatic residences, and little more can be said for the European 
society of Pera; it is about on a par with that of a third-rate provincial town in England. Ennui succeeds to curiosity, and indifference to ennui; and you gladly step into your caïque, or your araba; or, better still, spring into your saddle, to recreate yourself among scenes of beauty and magnificence, and to escape from "the everlasting larum" of "rounded sentences which tend to nothing." 


\section{CHAPTER V.}

The Greek Carnival - Kassim Pasha - The Marine Barrack - The Admiralty-Palace of the Capitan Pasha-Turkish Ships and Turkish Sailors-More Mistakes-Aqueduct of Justinian-The Serai - The Arsenal-The "Sweet Waters"-The Fanar - Interior of a Greek House-Courteous Reception-Patriarchal Customs-Greek Ladies at Home-Confectionary and Coffee-A Greek Dinner-Ancient and Modern Greeks-A Few Words on Education-National Politeness

-The Great Logotheti Aristarchi-His Politics - Sketch of his Father-His Domestic History-A Greek Breakfast-The Morning after a Ball-Greek Progress towards Civilization-Parallel between the Turk and the Greek.

The Greek Carnival extends three days beyond that of the Europeans; and, such being the case, we gladly accepted an invitation to a ball to be given by a wealthy Cesarean merchant, resident at the Fanar, or Greek quarter of Constantinople ; and I embarked in a caïque, with my father, under one of those bright spring suns which make the Bosphorus glitter like a plate of polished steel.

We took boat at Kassim Pasha, in the yard of the marine barrack, an extensive block of building, equally remarkable for its tawdry fresco-painted walls, and demolished windows; and close beside the Admiralty, a gay-looking edifice in the Russian taste, elaborately orna-

vol. $\mathrm{I}$. 
mented throughout its exterior, and adorned with peristyles on three of its sides. The rez-de chaussez contains apartments appropriated to the principal persons of the establishment, and public offices for the transaction of business. The next range are sacred to the Sultan, who occasionally passes a morning at Kassim Pasha, inspecting the progress of the vessels of war now building : and from the windows of his saloons looking down upon the line-of-battle ships in the harbour.

On a height a little in rear of the Admiralty stand the picturesque remains of the palace that was formerly inhabited by the Capitan Pasha; of which two long lines of grated arches still exist nearly perfect, having much the effect of an aqueduct; while a little cluster of towers, crowning the grass-grown acclivity, add a most interesting feature to the ruin.

On all sides of the caique towered a lordly vessel with its bristling cannon, and painted or gilt stern gallery, lying peacefully at anchor in the land-locked harbour; while the largest frigate in the world was busily preparing for sea as we passed under her bows, and her deck was all alive with men, in their red caps and close blue jackets; but I fear that the blue jackets of England would scarce seek to claim brotherhood with the tars of Turkey, for they have, in sooth, but a "lubberly" look with them; and it is commonly remarked that the 
Sultan has some of the finest vessels in the world, and some of the worst sailors.

As this was the first day of unclouded sunshine on which I had crossed the port, I looked around me in order to discover the "gilded domes" of which a modern traveller has spoken ; but, alas! - the truth must be told - not a mosque in Stamboul has a gilded dome; and the only approach to such a gorgeous object that I could discover were the gilded spires of the minarets of Sultan Mahmoud's mosque at 'Topp-hannè ; but, en revanche, the eye lingered long on the ruin of Justinian's aqueduct, which rises hoar and dark above the clustering houses of the city, spanning the two hills against which it rests, as with the grasp of centuriesupon the glittering pinnacles of the Seraï, flashing out amid the tall cypresses that hem them in; and on the elegant, but nearly untenanted, Seraglio itself, which stands upon the very edge of the lake-like sea, mirrored in the clear waters.

But these were soon left behind; and, as our sturdy rowers rapidly impelled us forward, we traced on our right hand the extensive outbuildings of the Arsenal, which bound the shore to the very extremity of the port, and only terminate at the point of the "Sweet Waters," where a lovely river empties itself into the harbour, and gives its name to the locality.

In ten minutes, we were at the Fanar, and 
landed on a wooden terrace washed by the waters of the port; and in five more we had passed into the garden to which it belonged, and thence into the house of the hospitable family who had offered us a home for the night.

Having traversed an extensive hall paved with stone, whence three flights of marble stairs gave admittance into different parts of the mansion, we passed through a long gallery, and entered the apartment in which the ladies of the family were awaiting our arrival. No chilling salutation of measured courtesy - no high-bred manifestation of " exclusive" indifference, greeted the foreign strangers ; but each in turn approached us with extended hand, and offered the kiss of welcome; and in less than a quarter of an hour we were all laughing and chatting as gaily in French, as though we had been the acquaintance of years.

No where do you feel yourself more thoroughly at home at once than among the inhabitants of the East ; they may be what we are accustomed to eall them-semi-barbarians-but, if such be the case, never was the aphorism of a celebrated female writer more thoroughly exemplified that " extreme politeness comes next to extreme sim. plicity of manners." Any privation that you may suffer in a 'Turkish or Greek house, beyond those consequent on the habits of the country, must be gratuitous, as the natives place a firm 
reliance on your asking for all that you require or wish; and they are so far from being obliged to you for a contrary mode of action, that you cannot more seriously offend than by giving them cause to suspect, after your departure, that you have been inconvenienced during your residence in their families.

The room in which we were received was of considerable extent, and surrounded on three sides by a sofa, like those in the Turkish houses, which were in fact copied from the Grecks; this was covered with a gay patterned chintz, and furnished with cushions of cut velvet of a rich deep blue; nor was the comfortable tandour wanting; and, when I had laid aside my cloak, shawl, and bonnet, and exchanged my walking shoes for slippers, I crept under the wadded coverings as gladiy as any Greek aniong them ; and, having surrounded ourselves with cushions, we all sat in luxurious idleness, speculating on the forthcoming ball, and relating anecdotes of those which were past.

Nothing can be more patriarchal than the domestic economy of a Greek family : that in which we were guests comprised three generations; and the respect and obedience shown by the younger branches to their vencrable relatives were at once beautiful and affecting. The aged grandmother, a noble remain of former beauty, with a profile which a sculptor must still have loved to look 
upon, so perfectly was its outline preservedwore her grey hair braided back from her forehead, and a dark shawl wound about her head-a long pelisse of brown cloth lined with rich fur, with wide sleeves, and an under-jacket of crimson merinos, doubled with marten-skin - her daughter, the mistress of the house, and the mother of twelve children, reminded me strongly of a Jewess, with her large, dark, flashing eyes, and high aquiline nose : her wide brow was cinctured with a costly Persian scarf; and during the day she three times changed the magnificent cachemere in which she was enveloped. The younger ladies wore turbans of gauze wreathed with flowers, very similar to those which are in use among our matrons for evening dress; their dark, luxuriant, glossy hair being almost entirely hidden; and furred pelisses that reached from the throat midway to the knee, whence the full petticoat of merinos, or chaly, fell in large folds to their feet.

As soon as we were comfortably established round the tandour, a servant brought in a tray on which were arranged a large cut glass vase, filled with a delicate preserve slightly impregnated with attur de rose, a range of crystal goblets of water, and a silver boat, whose oars were gilt tea-spoons. One of these the lady of the house immersed in the preserve, and offered to me; after which she replaced the spoon in 
the boat, and I then accepted a draught of water presented by the same hospitable hand; the whole ceremony was next gone through with my father ; and, the tray being dismissed, a second servant entered with coffee, served in little porcelain cups of divers patterns, without saucers, but deposited in stands of fillagreed silver, shaped nearly like the egg-cups of Europe.

After this, we were left to our charcoal and cushions until six o'clock; save that my father smoked a costly pipe with a mouth-piece of the colour and almost of the bulk of a lemon, in company of our host, a tall, majestic-looking man, upwards of six feet in height, whose black calpac differed from those of the Armenians in its superiority of size and globular form, and whose furred garments, heaped one above another, seemed to me, shivering as I had lately been under a sharp spring breeze on the water, the very embodiment of comfort.

A Greek dinner is a most elaborate business ; rendered still more lengthy by the fact that the knives, forks, and other appliances which European example has introduced, are as yet rather hindrances than auxiliaries to most of those who have adopted them.

When we had taken our places at table, I looked around me with considerable interest-we were truly a large party-all the junior members of 
the family, who had been throughout the morning " on household cares intent," were gathered around the board; and such a circle of bright black eyes I never beheld before in my life!

The very aspect of the repast was appetissant - the portly tureen of rice soup was surrounded by every tentative to appetite that can be enumerated ; pickled anchovies, shred cheese, dried sausage divided into minute portions, pickles of every description, salt tunny-fish, looking like condensed rose leaves, and Adrianople tongues sliced to the thinness of wafers. The sparkling Greek wines were laughing in light among dishes upheaped with luscious confectionarySciote pastry-red mullet, blushing through the garlanded parsley among which they were imbedded, and pyramids of pillauf slightly tinged with the juice of the tomato. More substantial dishes were rapidly handed round by servants, and a delicious dessert crowned the hospitable meal, at whose termination we hurried to our several apartments, and were soon immersed in all the mysteries of the toilet.

The house of the merchant by whom the ball was to be given, and whose name was Kachishesh Oglou, signifying "Son of the Hermit," was next door to that in which we were already guests ; and the cheerful music of the Wallachian band gave earnest of its commencement long ere we were ready to augment the festive 
crowd: and a crowd it truly was, a perfect social kaleidoscope; for the variety of costumes and colours in constant motion formed a gay and characteristic piece of human mosaic. There were the venerable men whose hair and beards had grown gray with age, and who had scorned to put off the garb of their fathers; the dark globular calpac and the graceful pelissethe tiers étât of fashion, in their semi-European dress, the ill-cut frock-coat, and the scarlet fèz, drawn down to their very eyebrows - and the young, travelled beaux, in their pride of superior knowledge and tenue, gloved and chausséd with a neatness and precision worthy of the school in which they had studied.

Among the ladies, the same graduated scale of fashion was perceptible: the elder matrons wore the dark head-dress and unbecoming vest of by-gone years, half concealed by the warm wrapping pelisse-the next in age had mingled the Greek and European costumes into one heterogeneous mass, each heightening and widening the absurdity of the other: and had overlaid the inconsistent medley with a profusion of diamonds absolutely dazzling; while the younger ladies presented precisely the same appearance as the belles of a third rate country town in England: their petticoats too short, their heads too high, their sleeves too elaborate, and their whole persons over-dressed. 
I have already remarked on the fondness of the Greek ladies for gay colours ; a taste peculiarly, and almost painfully, apparent in a ball-room: such bright blues, deep pinks, and glowing: scarlets I never before saw collected together; and this glaring taste extends even to their jewels, which they mix in the most extraordinary manner; their only care being to heap upon their persons every ornament that they can contrive to wear.

I cannot, however, record even this inconsequent criticism without a feeling of self-reproach, when I remember the kindliness of heart, and frankness of welcome, with which I was received among them. No curious impertinence taught me that I was felt to be a stranger; on the contrary, I was greeted with smiles on every side; each had something kind and complimentary to address to me ; and in ten minutes $I$ had been presented to every individual in the room whose acquaintance I could desire to make. Nor must I pass over without remark the progress of education among these amiable women; two. thirds of the younger ones speak French, many of them even fluently-several were conversant with English, and still more with Italian; while a knowledge of the ancient Greek is the basis of their education, and is consequently almost general. A taste for music is also rapidly obtaining; and time and greater facilities are alone 
wanting to lend the polish of high-breeding and high education to the Greek ladies : the material is there - they already possess intellect, quickness of perception, and a strong desire for instruction; and, even eminently superior as they already are to the Turkish and Armenian females, they are so conscious of their deficiencies both of education and opportunity, that, were these once secured to them, they would probably be inferior to no women in the world as regards mental acquirements.

I pass by the heavy-looking, but, nevertheless, handsome, son of the Prince of Samos, the minister of Moldavia - a group of Mickialis, Manolakis, Lorenzis, Arcolopolos, \&c., \&c., \&c., all dark-eyed and mustachioed-to particularize an individual who must ever be an object of great interest to all who are conversant with Eastern politics-I allude to Nicholas Aristarchi -Great Logotheti, or head of the clergy, and representative of the Greek nation in the Synodthe Aristarchi, who is accused by his enemies of having brought about the treaty of Unkiar Skelessi - of having caused Achmet Pasha to counsel the Sultan to cede some of his finest provinces to the Russians, in virtue of the convention of St. Petersburg; and, to crown all, of being in the receipt of a considerable pension, granted to him, in consideration of his services, by the Emperor Nicholas. 
Be all this as it may - and be it remembered that each of these assertions is totally discredited by a numerous party, who have taken a very different view of the political career of Logotheti, and who find a complete refutation of these charges against him, in the perilous situation of the Sultan when Mahomet Ali marched upon Qutayah - Mahmoud was without fleet or army-threatened by his people-abandoned by his friends-deserted by his allies-and reduced to the bare question of self-preservation. In this strait, uncounselled, unadvised, even unsuspected of such an intention, he personally invited the Russian fleet to protect him against his own subjects, nor did he abandon his purpose at the remonstrance of his own ministers, and those of the foreign powers.

During the succeeding four years, the Ottoman Government have persisted in the same views, as if in conviction of their efficacy ; and it is scarcely probable that a solitary individual, and that individual, moreover, a Greek raïah, could possess sulficient power to regulate the movements of a despotic government; while it is certain that Aristarchi is still in the confidence of the Turkish ministry, and is more or less interwoven in the intricate web of her political existence.

Many of those who have been the most violent against him have forgotten, or perhaps have never known, that he is the son of that 
Aristarchi who was sacrificed because he was too true to the cause which he had espoused: Aristarchi was the last Greek Dragoman to the Porte, and the confidant of Halet Effendi ; and, on the insurrection of his countrymen, he continued faithful to the interests of the Sultan, and steadily pursued the straight and manly line of policy which had induced him to support the views of England against those of Russia; but he was abandoned in his need by the power that he had, in his days of influence, exerted his best energies to serve. England changed her policy, and Aristarchi, abandoned to the tender mercies of the arch-traitor, Halet Effendi, was exiled to Boloo, under a promise of recall; but he ultimately lost his life, which no powerful hand was outstretched to save, simply because Aristarchi was the only individual whose personal and acquired rank rendered him eligible to fill the exalted station of Prince of Wallachia; and that he was unhappily the confidant of the treacherous intrigues of his patron, which that patron well knew that he possessed the power to disclose. Thus, forgotten on one hand, and betrayed on the other, he fell a sacrifice to the misgivings of Halet Effendi, who supplied his place with one less versed in the intricacies of his own subtle policy.

Logotheti saw his father cut to pieces before his eyes - murdered by the emissaries of those 
whom he had served with honour and fidelityhe beheld his mother put forth, with her seven helpless daughters, from the home that had so long been her's-he stood between his two young brothers, orphaned and beggared by the same stroke- he saw the possessions which should have been his own pass into the hands of strangers-and he knew and felt that on his individual exertions depended the comforts, the fortunes, the very existence, of those helpless and homeless beings.

I shall pursue the subject no farther for obvious reasons, suffice it that Nicholas Aristarchi, Great Logotheti and Chargé d'Affaires for Wallachia, was to me an object of surpassing interest: I had heard so much of him - I had imagined so much - and I had been so deeply affected by his domestic history - that I was anxious to see a man who had suffered so fearfully, who had struggled so manfully, and who had grappled with fortune until he saw it at his feet; and whose individual influence had sufficed to depose two Patriarchs, and to seat two others on the throne of the Greek church.

Nor did I, when I first met him, know the tendency of his politics; I was desirous only to make the acquaintance of a man who had become an object of great interest to me from the description and narration of an individual whom he had essentially served, and who had succeeded in awa- 
kening in my mind a wish to see and converse with him. My business was with the man; with the politician I had nothing to do. I thought only of the Aristarchi, who had saved and supported a ruined mother and a beggared family ; I cared not for the Dragoman, who had assisted at treaties, and passed his youth among the intrigues of cabinets. His domestic history was a little romance; my feelings of sympathy had been excited by the manner in which it was related to me; and I rejoiced in the opportunity of becoming known to him.

Logotheti was one of the first persons presented to me; and I instantly felt that, had I encountered him in a crowd, I could not have passed him by without remark. He is about five and thirty, of the middle size, and there is mind in every line of his expressive countenance his brow is high and ample, with the rich brown hair receding from it, as if fully to reveal its intellectual character; his bright and restless eyes appear almost to flash fire during his moments of excitement, but in those of repose their characteristic is extreme softness ; his nose is a perfect aquiline, and his moustache partially conceals a set of the whitest teeth I ever saw. As he stood conversing with me, I remarked that he constantly amused himself by toying with his beard, which he wears pointed, and of which he is evidently vain. His voice is extremely 
agreeable, his delivery emphatic, and he speaks French fluently.

After a few moments of conversation, he introduced me to his wife, his mother, and his sisters, all of whom greeted me with the greatest kindness; and in a few more, my hand was in his, and we were threading the mazes of a cotillon. I was much amused by the officiousness of his attendants; his pipe-bearer, whose tube (not staff) of office was of the most costly description, approached him every five minutes with the tempting luxury, of which he was, however, much too well-bred to avail himself while conversing with me; although the Greek ladies are accustomed to this social accessory, and many of the elder ones even indulge in it themselves - another handed to him from time to time a clean cambric handkerchief - while a third haunted him like his shadow, and the moment that we paused, either in the dance, or in our walk across the room, placed a couple of chairs for us to seat ourselves. Of this latter arrangement, he availed himself without scruple, and compelled me to do the same; while, as the evolutions of the figure constantly caused me to rise, he invariably stood leaning over the back of my empty chair, until I was again seated, ere he would resume his own.

As he persisted in dancing with me nearly the whole of the evening, and talking to me during 
the remainder, $\mathbf{I}$ soon became much interested in his conversation, and it was with sincere pleasure that I heard him promise that he would get up an extempore ball for us the following night. The news soon spread through the room, and great were the exertions made to secure invitations, the more particularly as the morrow was the last day of the Carnival; and, at half past four in the morning, after having received an invitation to breakfast with Madame Logotheti, we made our parting bow to our very handsome hostess and her hospitable husband, and hastened to secure a little rest, to enable us to contend with the fatigues of the forthcoming evening.

A Greek breakfast differs little from a Greek dinner: there are the same sparkling wines, the same goodly tureen of soup, the same meats, and confectionary, and friandises ; but, in addition to these, there is the snowy kaimack, or clotted cream, and the bubbling urn.

I know not whether others have made the same remark, but I have frequently observed that the breakfast after a ball, where the party is an agreeable one, is a most delightful repast. The excitement of the previous night has not entirely subsided - the "sayings and doings " of "ladies bright and cavaliers " afford a gay and unfailing topic-and all goes "merry as a marriage bell." Certain it is, that in this

$$
\text { voL. } 1 \text {. }
$$$$
\text { - } \mathbf{G}
$$ 
instance my theory is borne out by the result; for, on the termination of the meal, the family insisted on our remaining with them during our stay at the Fanar. Servants were accordingly despatched for our bandboxes and dressingcases, and we established ourselves comfortably round the tandour until dinner-time.

As the house which Logotheti occupied during the winter months was merely hired,* and, although extremely handsome and spacious, was greatly inferior in magnificence to his residence on the Bosphorus, he did not consider it expedient to give the ball himself, lest he should offend many whom he had neither time nor space to invite; but requested one of his friends, Hage Aneste, or Aneste the Pilgrim, a Primate of the Greek church and a near neighbour, to open his house in the evening, and the arrangement was completed at once.

If $I$ had been pleased with Logotheti in the heat and hurry of a ball room, I was infinitely more delighted with him in the bosom of his family. His gentle and courtly manners, and his unaffected and fluent conversation, rendered him a charming companion; and the hours flew so swiftly in his society, and that of his amiable

- As an example of the morals of the Greck clergy, it may not be impertinent to inention that this house was bequeathed by the Archbishop of Dercon, who died a few months ago at T'herapia, to Hesterine, la dame de ses pensées. 
family, that dinner was announced before the morning had appeared to be half spent.

At half past nine, we were in the ball-room, which I entered on the arm of Logotheti, and I was considerably startled during our progress up stairs by the manner of his reception. Our host and hostess met us on the first landingplace, where they bent down and kissed the hem of his garment, despite his efforts to prevent this truly Oriental salutation. Their example was followed by all those who made way for us ; and, as he led me through the noble saloon in which we were to dance, and seated me in the centre of the sofa, at the upper end of a drawing-room that opened into it, every one rose, and continued standing until he had taken possession of a chair.

Coffec having been handed round, Logotheti conducted me back into the saloon, where we opened the ball with a Polonaise; after which, quadrilles, waltzes, cotillons, and mazurkas, followed each other in rapid succession; and, after having been introduced to more persons than I could possibly recognise should I ever meet them again, and dancing until near six o'clock in the morning, I walked another Polonaise with our agreeable host, and quitted the ball-room with more regret than I ever experienced on a similar occasion.

We remained the morrow at the Fanar, and 
I carried away with me no memories save those of kindness and courtesy. Seldom, very seldom indeed, have I passed three days of such unalloyed gratification as those for which I am indebted to Logotheti and his friends.

No circumstance impressed me more strongly during this very agreeable visit, than the rapid strides which the Constantinopolitan Greeks are making towards civilization. The Turks have a thousand old and cherished superstitions that tend to clog the chariot wheels of social progression, and which it will require time to rend away; the Armenians, who consider their Moslem masters as the ne plus ultra of human perfection, are yet further removed from improvement than the Turks; while the Greeks, lively and quick-minded, seize, as it were by intuition, minute shades of character as well as striking points of manners. Locomotive, physically as well as mentally, they indulge their erratic tastes and propensities by travel; they compare, estimate, and adopt; they pride themselves in their progress ; they stand forth, scorning all half measures, as declared converts to European customs; and they fashion their minds as well as their persons, after their admitted models.

The Turk is the more stately, the more haughty, and the more self-centered, of the inhabitants of the East; but in all that relates 
to) social tactics he is very far inferior to the keen, shrewd, calculating, intriguing, Greek.

The Moslem will fix his eye upon a distant and important object, and work steadily onwards until he has attained it; but, meanwhile, the active Greek will have clutched a score of minor advantages, which probably, in the aggregate, are of more than equal weight. It is the collision of mind and matter - the elephant and the fox. Intellectual craft has been the safetybuoy of the Greeks; had they been differently constituted, they would long ere this have been swept from the face of the earth, or have become mere "hewers of wood and drawers of water." As it is, there is so strong a principle of moral life in this portion of the Greek nation, that, were they only more united among themselves, and less a prey to intestine jealousies and heartburnings, it is probable that in these times, when Turkey lies stretched like a worsted giant at the mercy of the European powers, the heel of the Greeks might be shod with an iron, heavy enough to press her down beyond all means of resuscitation; in possession, as they are, of the confidence of those in power.

Animal force has subjugated the Greekssubjugated, but not subdued them ; their physical power has departed, but their moral energy remains unimpaired; and it is doubtful whether human means will ever crush it. 


\section{CHAPTER VI.}

Difficulty of Obtaining an Insight into Turkish Character - Inconvenience of Interpreters - Errors of Travellers - Ignorance of Resident Furopeans - Fables and Fable-mongers - Turkey, Loeal and Moral - Absence of Capital Crime - Police of Constantinople - Quiet Streets-Sedate Mirth-Practical Philosophy of the Turks-National Emulation-Impossibility of Revolution-Mahmoud and his PeopleUnpopularity of the Sultan - Russian Interference - Vanity of the 'Turks - Russian Gold - Tenderness of the Turks to Animals Penalty for Destroying a Dog - The English Sportsman-Fondness of the 'Turks for Children-Aneedote of the Reiss Effendi-Adopted Children - Love of the Musselmauns for their Mothers - Turkish Indifference to Death-Their Burial-places-Fasts-The Turks in the Mosque-Contempt of the Natives for Europeans - Freedom of the Turkish Women-Inviolability of the Harem-Domestic Economy of the Harem - Turkish Slaves - Aneedote of a Slave of Aclimet Pasha-Cleanliness of Turkish Houses-The Real Romance of the East.

There is, perhaps, no country under heaven where it is more difficult for an European to obtain a full and perfect insight into the national character, than in Turkey. The extreme application, and the length of time necessary to the acquirement of the two leading languages, which bear scarcely any affinity to those of Europe, render the task one of utter hopelessness to the traveller, who consequently labours under the disadvantage of explaining his impressions, and secking for information through 
the medium of a third person, inferentially, and it may almost be said totally, uninterested in both. The most simple question may be put in a manner calculated to influence the reply; as the rivulet takes the tinge of the soil over which it passes - a misplaced emphasis may change the nature of an assertion; and no one requires to be reminded of the difficulty, if not impossibility, of meeting with an individual so straightforward and matter-of-fact as to translate as though he were perpetually in foro conscientia. Thus the means of communication between the native and the stranger have an additional and almost insurmountable impediment in this respect, superadded to the natural and palpable obstacles presented by opposing and diffluent prejudices, customs, and opinions.

Flung back, consequently, upon his own.resources; soured, perhaps somewhat, by the consciousness that he is so, and judging according to his own impressions, the traveller hazards undigested and erroneous judgments on the most important facts - traces effects to wrong causes-and, deciding by personal feeling, condemns much that, did he perfectly and thoroughly comprehend its nature and tendency, he would probably applaud. Hence arise most of those errors relative to the feelings and affairs of the East, that have so long misled the public mind in Europe; and, woman as I am, I 
cannot but deplore a fact which I may be deficient in the power to remedy. The repercussion of public opinion must be wrought by a skilful and a powerful hand, They are no lady-fingers which can grasp a pen potent enough to overthrow the impressions and prejudices that have covered reams of paper, and spread scores of misconceptions. But, nevertheless, like the mouse in the fable, I may myself succeed in breaking away a few of the meshes that imprison the lion ; and, as I was peculiarly situated during my residence in the East, and enjoyed advantages and opportunities denied to the generality of travellers, who, as far as the natives are concerned, pass their time in Turkey " unknowing and unknown," I trust that my attenipt to refute the errors of some of my predecessors, and to advance opinions, as well as to adduce facts, according to my own experience, may not entail on me the imputation of presumption.

I know not whether it may have been from want of inclination, but it is certain that Europeans are at this moment resident in Turkey, as ignorant of all that relates to her political economy, her system of government, and her moral ethics, as though they had never left their own country: and who have, nevertheless, been resident there for fifteen or twenty years. If you succeed in prevailing on them to speak on the subject, they never progress beyond exani- 
mate and crude details of mere external effects. They have not exerted themselves to look deeper; and it may be supererogatory to add, that at the Embassies the great question of Oriental policy is never discussed, save en petit comité. It is also a well-attested fact that the entrée of native houses, and intimacy with native families, are not only extremely difficult, but in most cases impossible to Europeans; and hence the cause of the tissue of fables which, like those of Scheherazade, have created genii and enchanters $a b$ ovo usque ad mala, in every account of the East. The European mind has become so imbued with ideas of Oriental mysteriousness, mysticism, and magnificence, and it has been so long accustomed to pillow its faith on the marvels and metaphors of tourists, that it is to be doubted whether it will willingly cast off its old associations, and suffer itself to be undeceived.

To the eye, Turkey is, indeed, all that has been described, gorgeous, glowing, and magnificent; the very position of its capital seems to claim for it the proud title of the "Queen of Cities." 'Throned on its seven hills, mirrored in the blue beauty of the Bosphorus-that glorious strait which links the land-locked harbour of Stamboul to the mouth of the Euxine - uniting two divisions of the earth in its golden grasplording it over the classic and dusky mountains 
of Asia, and the laughing shores of Europethe imagination cannot picture a site or scene of more perfect beauty. But the morale of the Turkish empire is less perfect than its terrestrial position; it possesses the best conducted people with the worst conducted government-ministers accessible to bribes - public functionaries practised in chicane - a court without consistency, and a population without energy.

All these things are, however, on the surface, and cannot, consequently, escape the notice of any observant traveller. It is the reverse of the picture that has been so frequently overlooked and neglected. And yet who that regards, with unprejudiced eyes, the moral state of Turkey, can fail to be struck by the absence of capital crime, the contented and even proud feelings of the lower ranks, and the absence of all assumption and haughtiness among the higher?

Constantinople, with a population of six hundred thousand souls, has a police of one hundred and fifty men. No street-riots rouse the quiet citizens from their evening cogitations-no gaminghouse vomits forth its throng of despairing or of exulting votaries-no murders frighten slumber from the pillows of the timid, "making night hideous " - no ruined speculator terminates his losses and his life at the same instant, and thus bequeathes a double misery to his survivors-no inebriated mechanic reels homeward to wreak 
his drunken temper on his trembling wife-the Kavashlir, or police of the capital, are rather for show than use.

From dusk the streets are silent; save when their echoes are awakened by the footfalls of some individual who passes, accompanied by his servant bearing a lantern, on an errand of business or pleasure. Without these lanterns, no person can stir, as the streets of the city are not lighted, and so ill-paved that it would be not only difficult, but almost dangerous, to traverse them in the dark. If occasionally some loud voice of dispute, or some ringing peal of laughter, should scare the silence of night, it is sure to be the voice or the laughter of an European, for the Turk is never loud, even in his mirth; a quiet, internal chuckle, rather seen upon the lips than sensible to the ear, is his greatest demonstration of enjoyment; and while the excitable Greek occasionally almost shrieks out his hilarity, the Musselmaun will look on quietly, with the smile about his mouth, and the sparkle in his eye, which are the only tokens of his anticipation in the jest.

The Turks are the most practical philosophers on earth ; they are always contented with the present, and yet ever looking upon it as a mere fleeting good, to which it were as idle to attach any overweening value, as it would be to mourn it when it escapes them. Honours and wealth are 
such precarious possessions in the East, that men cannot afford to waste existence in weak repinings at their loss; nor are they inclined to do so, when they remember that the next mutation of the Imperial will may reinstate them, unquestioned and untrammelled, in their original position.

It is true that the sharpest sting of worldly misfortune is spared to the Turk, by the perfect similarity of habit and feeling between the rich and the poor; and he also suffers less morally than the European, from the fact that there exists no aristocracy in the country, either of birth or wealth, to ride rough-shod over their less fortunate fellow-men. The boatman on the Bosphorus, and the porter in the streets - the slave in the Salemliek, and the groom in the stables, are alike eligible to fill the rank of Pashathere is no exclusive clique or caste to absorb "the loaves and fishes" of office in Turkey the butcher of to-day may be the Generalissimo of to-morrow; and the barber who takes an Effendi by the nose on Monday may, on Tuesday, be equally authorized to take him by the hand.

To this circumstance must be attributed, in a great degree, the impossibility of a revolution in Turkey; but another may also be adduced of at least equal weight. In Europe, the subversion of order is the work of a party who have everything to gain, and who, from possessing no individual interest in the country, have 
consequently nothing to lose. To persons of this class, every social change offers at least the prospect of advantage ; but, throughout the Ottoman empire, nearly every man is the owner of a plot of land, and is enabled to trim his own vine, and to sit under the shadow of his own fig-tree - he has an interest in the soil - and thus, although popular commotions are of frequent occurrence, they merely agitate; without exasperating the feelings of the people.

The Osmanli is, moreover, mentally, as well as physically, indolent-he is an enemy to all unnecessary exertion; and the subjects of Sultan Mahmoud have never threatened him with rebellion because he refused to grant any change in their existing privileges and customs, but, on the contrary, because he sought to introduce innovations for which they had never asked, and for which they had no desire. "Why," they exclaim in their philosophy, "why seek to alter what is well? If we are content, what more can we desire?" And, acting upon this principle, they resist every attempt at change, as they would a design against their individual liberty.

This fecling has induced the great unpopularity of the Sultan; who, in his zeal to civilize the Empire, has necessarily shocked many privileges and overturned many theories. That he is unpopular, unfortunately admits of no doubt, even in the minds of those most at- 
tached to his interests - the very presence of Russian arms within his Imperial territory sufficiently attest the fact: and it is to be feared that he will discover, when too late, that these apparent means of safety were the actual engines of his destruction. Be this as it may, it is certain that the Russian alliance has given great and rational umbrage to the bulk of his people; and, combined with his own mania for improvement and innovation, has caused a want of affection for his person, and a want of deference for his opinions, which operate most disadvantageously for his interests.

That the Russian influence has negatived the good effects of many of his endeavours is palpable, and forces itself daily on the notice of those who look closely and carefully on the existing state of things at Constantinople. It is the policy of Russia to check every advance towards enlightenment among a people whom she has already trammelled, and whom she would fain subjugate. The Turk is vain and selfcentered, and consequently most susceptible to flattery. Tell him that he is "wisest; virtuousest, discreetest, best," and his own self-appreciation leads him immediately toput firm faith in the sincerity of your assertion; the effect of this blind trust is evident at once-it paralyzes all desire of further improvement: he holds it as supererogatory to "gild refined gold, and 
paint the lily," and he thus stops short at the threshold, when he should press forward to the arena.

These sober statements are sad innovators on our European ideas of Eastern magnificence, but they are, nevertheless, too characteristic to be passed over in silence.

To all the brute creation the Turks are not only merciful but ministering friends; and to so great an extent do they carry this tenderness towards the inferior animals, that they will not kill an unweaned lamb, in order to spare unnecessary suffering to the mother; and an English sportsman, who had been unsuccessful in the chase, having, on one occasion, in firing off his piece previously to disembarking from his caïque, brought down a gull that was sailing above his head, was reproached by his rowers with as much horror and emphasis as though he had been guilty of homicide.

I have elsewhere remarked on the singular impunity enjoyed by the aquatic birds which throng the harbour of Constantinople, and sport among the shipping; on the divers, that may be knocked down by the oar of every passing caïque, so fearless are they of human vicinity; and the gulls, which cluster like pigeons on the roofs of the houses - on the porpoises that crowd the port, and the dogs that haunt the streets. It may not be unamusing to state the 
forfeit inflicted on an individual for destroying one of these animals, as it is both curious and characteristic. The dead dog is hung up by the tail in such a manner as to suffer his nose to touch the ground; and his murderer is compelled to cover him entirely with corn or millet seed, which is secured by the proper authorities, and distributed to the poor. This ceremony generally costs the delinquent about a thousand piastres.

Another distinguishing trait in the Turkish character is their strong parental affection; indeed I may say love of children generally. Nothing can be more beautiful than the tenderness of a Turkish father; he hails every demonstration of dawning intellect, every proof of infant affection, with a delight that must be witnessed to be thoroughly understood; he anticipates every want, he gratifies every wish, he sacrifices his own personal comfort to ensure that of his child; and I cannot better illustrate this fact than by mentioning a circumstance which fell under my own observation.

The Reiss Effendi, or Minister for Foreign Affairs, had a grandchild whose indisposition caused him the most lively uneasiness; it was in vain that his English physician assured him of the total absence of danger ; his every thought, his every anxiety, were with this darling boy; in the midst of the most pressing public business, 
he would start up and hasten to the chamber of the little patient, to assure himself that everything was going on favourably; he would leave his friends, in an hour of relaxation, to sit beside the sick bed of the child; and at length, when a strict and rigid system of diet was prescribed, which was to be of a fortnight's duration, he actually submitted himself, and compelled all his establishment to submit, to the same monotonous and scanty fare, lest the boy should accidentally see, or otherwise become conscious of the presence of, any more enticing food, for which he might pine, and thus increase his malady.

It may be thought that I have cited an extreme instance, but such is, in reality, far from being the case; indeed, to such a pitch do the Osmanlis carry their love for children, that they are constantly adopting those of others, whom they emphatically denominate "children of the soul." They generally take them into their families when mere infants; they rear them with the most extreme care and tenderness: and finally portion them on their marriage, as though the claim were a natural, rather than a gratuitous, one. The adopted child of Turkey is not like the protegé of Europe, the plaything of a season, and ultimately too often the victim of a whim: the act of adoption is with the Turks a solemn obligation; and poverty and privation

VOL. I. 
would alike fail to weary them of well-doing: where their affections as well as their word were pledged.

An equally beautiful feature in the character of the Turks is their reverence and respect for the author of their being. Their wives advise and reprimand unheeded-their words are bosh -nothing-but the mother is an oracle; she is consulted, confided in, listened to with respect and deference, honoured to her latest hour, and remembered with affection and regret beyond the grave. "My wives die, and I can replace them," says the Osmanli ; "my children perish, and others may be born to me; but who shall restore to me the mother who has passed away, and who is seen no more?"

These are strong traits, beautiful developments, of human nature; and, if such be indeed the social attributes of " barbarism," then may civilized Europe, amid her pride of science and her superiority of knowledge, confess that herein at least she is mated by the less highly-gifted Musselmauns.

The philosophy and kindly feeling of the Turk is carried even beyond the grave. He looks upon death calmly and without repugnance ; he does not connect it with ideas of gloom and horror, as we are too prone to do in. Europehe spreads his burial places in the sunniest spots. -on the crests of the laughing hills, where they 
are bathed in the light of the blue sky; beside the crowded thoroughfares of the city, where the dead are, as it were, once more mingled with the living - in the green nooks that stretch down to the Bosphorus, wherein more selfish spirits would have erected a villa, or have planted a vineyard. He identifies himself with the generation which has passed away - he is ready to yield his place to that which is to succeed his own.

Nor must I omit to remark on the devout and unaffected religious feeling that exists in Turkey, not only among the Musselmauns, who, however imperative may be their avocations, never neglect to pray five tinies during the day ; but equally among the Greeks and Armenians, whose fasts are so severe that those of the Roman Catholics are comparatively feasts. If you meet a Turk and inquire after his health, he replies"Shukiur Allah!-Praise be to God, I am well." Every thing is referred to the Great First Cause. There is none of that haughty self-dependence, that over-weening morgue, so strongly marked in Europeans. Among men, the Osmanli considers himself the first, but only among men; when he puts off his slippers at the door of the mosque, he carries no pomp with him into the presence of his God. The luxurious inhabitant of the East, who, in his own salemliek is wont to recline on cushions, and to be served by officious 
slaves, does. not pass into the house of God to tenant a crimson-lined and well-wadded pew, and to listen to the words of inspiration beside a comfortable stove, in dreamy indifference: he takes his place among the crowd - the Effendi stands beside the water-carrier - the Bey near the charcoal-vender-he is but one item among many - he arrogates to himself no honour in the temple where all men are as one common family; and he insults not the Divine Majesty by a bended knee and a stubborn brow.

That the generality of the Turks hold every Frank in supreme contempt, admits of no doubt; and could they, to use their own phrase, "make our fathers and mothers eat dirt," I am afraid that our respectable ancestors would never again enjoy a comfortable meal; but this feeling on their part is rather amusing than offensive, and only enhances the merit of their politeness when they show courtesy to the stranger and the Giaour.

If, as we are all prone to believe, freedom be happiness, then are the Turkish women the happiest, for they are certainly the freest individuals in the Empire. It is the fashion in Europe to pity the women of the East; but it is ignorance of their real position alone which can engender so misplaced an exhibition of sentiment. I have already stated that they are permitted to expostulate, to urge, even to insist on 
any point wherein they may feel an interest; nor does an Osmanli husband ever resent the expressions of his wife; it is, on the contrary, part and parcel of his philosophy to bear the storm of words unmoved; and the most emphatic and passionate oration of the inmates of his harem seldom produces more than the trite "Bakalum-we shall see."

It is also a fact that though a Turk has an undoubted right to enter the apartments of his wives at all hours, it is a privilege of which he very rarely, I may almost say, never avails himself. One room in the harem is appropriated to the master of the house, and therein he awaits the appearance of the individual with whom he wishes to converse, and who is summoned to his presence by a slave. Should he, on passing to his apartment, see slippers at the foot of the stairs, he cannot, under any pretence, intrude himself in the harem: it is a liberty that every woman in the Empire would resent. When guests are on a visit of some days, he sends a slave forward to announce his approach, and thus gives them time and opportunity to withdraw.

A Turkish woman consults no pleasure save her own when she wishes to walk or drive, or even to pass a short time with a friend: she adjusts her yashmac and feridjhe, summons her slave, who prepares her boksha, or bundle, neatly arranged in a muslin handkerchief; and, on the 
entrance of the husband, his inquiries are answered by the intelligence that the Hanoum* Effendi is gone to spend a week at the harem of so and so. Should he be suspicious of the fact, he takes steps to ascertain that she is really there; but the idea of controlling her in the fancy, or of making it subject of reproach on her return, is perfectly out of the question.

The instances are rare in which a Turk, save among the higher ranks, becomes the husband of two wives. He usually marries a woman of his own rank; after which, should he, either from whim, or for family reasons, resolve on increasing his establishment, he purchases slaves from Circassia and Georgia, who are termed Odaliques; and who, however they may succeed in superseding the Buyuk Hanoum, or head of the harem, in his affections, are, nevertheless, subordinate persons in the household; bound to obey her bidding, to pay her the greatest respect, and to look up to her as a superior. Thus a Turkish lady constantly prefers the introduction of half a dozen Odaliques into her harem to that of a second wife; as it precludes the possibility of any inconvenient assumption of power on the part of her companions, who must, under all circumstances, continue subservient to her authority.

The almost total absence of education among

- Signifying mistress, or lady. 
Turkish women, and the consequently limited range of their ideas, is another cause of that quiet, careless, indolent happiness that they enjoy; their sensibilities have never been awakened, and their feelings and habits are comparatively unexacting: they have no factitious wants, growing out of excessive mental refinement; and they do not, therefore, torment themselves with the myriad anxieties, and doubts, and chimeras, which would darken and depress the spirit of more highly-gifted females. Give her shawls, and diamonds, a spacious mansion in Stamboul, and a sunny palace on the Bosphorus, and a Turkish wife is the very type of happiness; amused with trifles, careless of all save the passing hour; a woman in person, but a child at heart.

Were I a man, and condemned to an existence of servitude, I would unhesitatingly chuse that of slavery in a Turkish family: for if ever the "bitter draught" can indeed be rendered palatable, it is there. The slave of the Osmanli is the child of his adoption; he purchases with his gold a being to cherish, to protect, and to support; and in almost every case he secures to himself what all his gold could not command -a devoted and loving heart, ready to sacrifice its every hope and impulse in his service. Once forget that the smiling menial who hands you your coffee, or pours the rose-water on your 
hands from an urn of silver, has been purchased at a price, and you must look with admiration on the relative positions of the servant and his lord-the one so eager and so earnest in his services-the other so gentle and so unexacting in his commands.

No assertion of mine can, however, so satisfactorily prove the fact which I have here advanced, as the circumstance that almost all the youth of both sexes in Circassia insist upon being conveyed by their parents to Constantinople, where the road to honour and advancement is open to every one. The slaves receive no wages; the price of their services has already been paid to their relatives; but twice in the year, at stated periods, the master and mistress of the family, and, indeed, every one of their superiors under the same roof, are bound to make them a present, termed the Backshish, the value of which varies according to the will of the donor; and they are as well fed, and nearly as well clothed, as their owners.

As they stand in the apartment with their hands folded upon their breasts, theyoccasionally mix in the conversation unrebuked; while, from their number, (every individual maintaining as many as his income will admit), they are never subjected to hard labour; indeed, I have been sometimes tempted to think that all the work of 
a Turkish house must be done by the fairies; for, although I have been the inmate of several harems at all hours, I never saw a symptom of any thing like domestic toil.

There is a remarkable feature in the position of the Turkish slaves that I must not omit to mention. Should it occur that one of them, from whatever cause it may arise, fecls himself uncomfortable in the house of his owner, the dissatisfied party requests his master to dispose of him ; and, having repeated this appeal three several times, the law enforces compliance with its spirit; nor is this all - the slave can not only insist on changing owners, but even on selecting his purchaser, although he may by such means entail considerable loss on his master. But, as asseveration is not proof, I will adduce an example.

The wife of Achmet Pasha had a female slave, who, being partial to a young man of the neighbourhood, was desirous to become his property. Such being the case, she informed her mistress that she wished to be taken to the market and disposed of, which was accordingly carried into effect; but, as she was young and pretty, and her lover in confined circumstances, he was soon outbidden by a wealthier man; and, on her return to the harem of Achmet Pasha, her mistress told her that an Asiatic merehant had offered twenty thousand 
piastres for her, and that she would be removed to his house in a few days. "I will not belong to him," was the reply; "there was a young man in the market who bid twelve thousand for me, and I have decided to follow him. My price to you was but ten thousand piastres, and thus you will gain two thousand by selling me to him." Her declaration was decisive : she became the property of her lover, and her resolution cost her mistress eighty pounds sterling.

The most perfect cleanliness is the leading: characteristic of Eastern houses-not a grain of dust, not a foot-mark, defaces the surface of the Indian matting that covers the large halls, whence the several apartments branch off in every direction; the glass from which you drink is carefully guarded to avoid the possibility of contamination; and, the instant that you have eaten, a slave stands before you with water and a napkin to cleanse your hands. To the constant use of the bath I have already alluded; and no soil is ever seen on the dress of a Turkish gentlewoman.

I am quite conscious that more than one ladyreader will lay down my volume without regret, when she discovers how matter-of-fact are many of its contents. The very term "Oriental" implies to European ears the concentration of romance; and I was long in the East ere I could divest myself of the same feeling. It would 
have been easy for me to have continued the illusion, for Oriental habits lend themselves greatly to the deceit, when the looker-on is satisfied with glancing over the surface of things; but with a conscientious chronicler this does not suffice; and, consequently, I rather sought to be instructed than to be amused, and preferred the veracious to the entertaining.

This bowing down of the imagination before the reason is, however, the less either a merit on the one hand, or a sacrifice on the other, that enough of the wild and the wonderful, as well as of the bright and the beautiful, still remains, to make the East a scene of enchantment. A sky, whose blue brilliancy floods with light alike the shores of Asia and of Europe - whose sunshine falls warm and golden on domes, and minarets, and palaces - a sea, whose waves glitter in silver, forming the bright bond by which two quarters of the world are linked together-an Empire, peopled by the gathering of many nations-the stately Turkthe serious Armenian-the wily Jew-the keeneyed Greek-the graceful Circassian-the desert-loving Tartar-the roving Arab-the mountain-born son of Caucasus - the voluptuous Persian-the Indian Dervish, and the thoughtful Frank - each clad in the garb, and speaking the language of his people; suffice to weave a web of tints too various and too brilliant to be 
wrought into the dull and common-place pattern of every-day existence.

I would not remove one fold of the graceful drapery which veils the time-hallowed statue of Eastern power and beauty ; but I cannot refrain from plucking away the trash and tinsel that ignorance and bad taste have hung about it; and which belong as little to the masterpiece they desecrate, as the votive offerings of bigotry and superstition form a part of one of Raphaël's divine Madonnas, because they are appended to her shrine. 


\section{CHAPTER VII.}

The Harem of Mustafa Effendi - The Ladies of the Harem - Etiquettical Observances of the Harem-Ceremonies of the Salemliek Jealousy of Precedence among the Turkish Women - Apartment of the Effendi-Eastern Passion for Diamonds-Personal Appearance of Mustafa Effendi-The little Slave-girl-Slavery in Turkey-Gallant Present-The Diuner - Turkish Cookery - Illuminated MosquesThe Bokshaliks-The Toilet after the Bath-History of an Odalique -Stupid Husbands-Reciprocal Commiseration - Errors of a Modern French Traveller-Privacy of the Women's Apartments-Anecdote of the Wife of the Kiara Bey-The Baïram Bokshalik-My Sleepingroom - Forethought of Turkish Hospitality - Farewell to liatma Hanoum-Dense Crowd-Turkish Mob-Turkish Officers-Military Difficulty - The "Lower Orders" - Tolerance of the Orientals towards Foreigners-Satisfactory Expedient.

ON the eve of the Baïram which terminates the Ramazan, we passed over to Constantinople with some friends to visit Mustafa Effendi, the Egyptian Chargé d'Affaires, whose magnificent mansion is situated near the gate of the Seraglio. Having passed the portal, we found ourselves in a spacious and covered court, having on our right hand a marble fountain, into whose capacious basin the water fell murmuringly from a group of lion's heads ; and, beyond it, the entrance to the women's apartments, with the conventual- 
looking wheel, by means of which food is introduced into the harem; and on our left a stately staircase leading to the main body of the building. Here our party were compelled to separate; the gentlemen put off their boots, and followed the two black slaves who awaited them, to the suite of rooms occupied by the master of the house, while my companion and myself were consigned to the guidance of a third attendant, who beat upon the door of the harem, and we entered a large hall paved with marble, and were immediately surrounded by half a dozen female slaves, who took our shoes, shawls, and bonnets, and led us over the fine Indian matting of the centre saloon, to the richlyfurnished apartment of the lady of the house.

A soft twilight reigned in the room, of which all the curtains were closely drawn to exclude the sun; and the wife of the minister and her daughter-in-law were seated at the tandour, engaged in conversation with several of their attendants, who stood before them in a half circle, with their arms folded upon their breasts. The elder lady was the most high-bred person whom I had yet seen in the country; the younger one was pale and delicate, with eyes like jet, and a very sweet and gentle expression; she spoke but seldom, and always in monosyllables, being evidently overawed by the presence of her companion. 
There are probably few nations in the world that observe with such severity as the Turks that domestic precedence and etiquette, which, while it may certainly prevent any disrespectful familiarity, has a tendency to annihilate all ease: Thus, the other ladies of the family are each inferior to the first wife, who takes the upper seat on the sofa, and regulates all the internal economy of the women's apartments: and, although they may be greatly preferred by the husband, they are, nevertheless, bound to obey her commands, and to treat her with the respect due to a superior. In the Salemliek, when she is desired by her lord to be seated, (without which gracious intimation she must continue standing before him), she is privileged to place herself on the same sofa, but on its extreme edge, and at a considerable distance; while the other ladies are only permitted to fold their feet under them on a cushion spread upon the carpet, and thence look up to the great and gracious ruler of their destinies! The ceremonies of the Salemliek are neither forgotten nor neglected in the harem, and it is customary for all the slaves. to bend down and kiss the hem of their mistress's garment on her first appearance in the morning.

These heart-shutting observances cannot fail to heighten the jealousy which their relative position must naturally excite in the bosoms of 
the other inmates of the harem, although such a circumstance as rebellion against the supreme power is never heard of, nor imagined.

During the day we were summoned to the apartment of the minister; whither, as the invitation was not extended to his wife, we went, accompanied only by three or four black slaves. After traversing several long galleries and halls, covered so closely with matting that not a footfall could be heard, we passed under the tapestry-hanging that veiled the door of the Effendi's apartment, and found ourselves in an atmosphere so heavy with perfume that for a moment it was almost suffocating.

The venerable Chargé d'Affaires, who had been long an invalid, was sitting upon his sofa, surrounded by cushions of every possible size and shape, wrapped in furs, and inhaling the odour of a bunch of musk lemons, the most sickly and sating of all savours-a magnificent mangal, upheaped with fire, occupied the centre of the apartment; the divan was almost covered with inlaid boxes, articles of bijouterie, books, and papers; a large silver tray resting upon a tripod was piled pyramidically with fine winter fruits; and within a recess on one side of the . room were ranged a splendid coffee service of French porcelain, and a pair of tall and exquisitely-wrought essence-vases of fillagreed silver-in short, the whole aspect of the apart- 
ment would have satisfied the most boudoirloving petite-maitresse of Paris or London. Near the mangal stood the four attendants of the master of the house, two fine boys of twelve or fourteen years of age, and two pretty little girls, one or two years younger, gorgeously dressed, and wearing magnificent brilliant ornaments on their heads and bosoms.

The rage for diamonds is excessive among both the Turks and the Greeks; but, while the Greek ladies delight in heaping upon their persons every ornament for which they can find space, many of the fair Osmanlis, with a pretty exclusive scorn of adventitious attraction, content themselves with a clasp or two, a bracelet, or some similar bagatelle; and decorate their favourite slaves with their more costly and ponderous jewels.

A most venerable-looking person was Mustafa Effendi, with his lofty turban, and his snowwhite beard; and he received us so kindly, and discoursed with us so good-humouredly, that I was delighted with him. A chair was brought for the Greek lady who had accompanied me, but he motioned to me to place myself on a pile of cushions at his side, where I remained very comfortably during the whole of our visit. He took a great quantity of snuff from a box whose lid was richly set with precious stones; and, on my admiring it, showed me another containing his

vOL. I. 
opium pills, which was exquisitely inlaid with fine large brilliants.

My attention being attracted to the rosy, happy-looking little slave-girl who stood near me, with her chubby arms crossed before her, her large pink trowsers completely concealing her naked feet, and her long blue antery richly trimmed with yellow floss-silk fringe, lying upon the carpet; he beckoned her to him, called her a good child, who had wit enough to anticipate his wants, and affection enough to supply them without bidding, and bade me remark the henna with which the tips of her toes and fingers were deeply tinged. She was, he said, a Georgian, whom he had purchased of her mother for six thousand piastres; she had already been in his house two years; and he hoped some day to give her a marriage portion, and to see her comfortably established, as she was a good girl, and he was much attached to her. The other, he added, was also obedient and willing, but she did not possess the vivacity and quickness of his little favourite - she had cost him seven thousand piastres, as she was a year older, and considerably stronger than her companion; and was a Circassian, brought to Constantinople, and sold, at her own request, by her parents.

When I remembered that these children were slaves, I felt inclined to pity them-when the very price which had been paid for them was 
stated to me, a sickness crept over my heart but, as I looked upon the pleased and happy countenances of the two little girls, and remembered that slavery, in Turkey at least, is a mere name, and in nine cases out of ten even voluntary, I felt that here my commiseration would be misplaced.

Soon after we had taken leave of the gentle and gracious old Effendi, a basket of delicious fruit was sent into the harem for our use, with an injunction that we should dine alone, lest we should be inconvenienced by the national habits. An embroidered carpet was consequently spread, beside which were placed a couple of cushions; and the dinner tray, such as I have before described it, was lifted into the apartment of the younger lady, at her earnest request: nine slaves, forming - a line from the table to the door, waited upon us: and we partook of an endless variety of boiled, stewed, roasted, and baked-delicious cinnamon soupchickens, farcied with fine herbs and olives-anchovy cakes - lemon-tinted pillauf - chopped meat and spiced rice, rolled in preserved vineleaves - the most delicate of pastry, and the most costly of conserves. Many-coloured sherbets, and lemonade, completed the repast; and when I laid aside my gold-embroidered napkin, and wiped the rose-water from my hands, I could but marvel at the hyper-fastidiousness of those 
travellers who have affected to quarrel with the Turkish kitchen; or infer that they had only " assisted" at the tables of hotels and eating-houses.

From the windows of the apartment, we had an excellent view, when the evening had elosed in, of the illuminated mosques of the city, and the lines of light that hung like threads of fire from minaret to minaret. The casements quivered beneath the shock of the rattling cannon; and all the sounds which came to us from without spoke of festivity and rejoicing; and, meanwhile, we were a happy party within. Fatma Hanoum smoked her pipe, and overlooked the distribution of the bokshaliks that her daughter was preparing for the morrow-every member of the household, on the occasion of the Baïram, being entitled to a present, more or less valuable according to their deserts, the length and difficulty of their services, or the degree of favour in which they are held.

We, meanwhile, amused ourselves with watching the slaves, who, having left the bath, had seated themselves in groups at the lower end of the apartment, combing, tressing, and banding their dark, glossy hair; the younger ones forming it into one long, thick plait, hanging down the centre of the back, and twisting above it the painted handkerchief, so popular in the harem that it is worn equally by the Sultana and the slave; the others binding their tresses tightly 
about their heads, and replacing the locks which they hid from view with a profusion of false hair, braided in twenty or thirty little plaits, and reaching round the whole width of the shoulders.

All were busily engaged in preparing for the festival of the morrow, though many of them were aware that they should not leave the harem; it was sufficient that it was a festival, an excitement, a topic of conversation, something, in short, to engross their thoughts; and no belle ever prepared for a birthday with more alacrity than did the females of the harem of Mustafa Effendi, black and white, for the Baïram.

In the course of the evening, the Bayuk Hanoum was summoned to her husband, and then the timid wife of her son joined us at the tandour, and related to us the little history of her life, which, although by no means remarkable in Turkey, is so characteristic, and will, moreover, appear so extraordinary to European readers, that I shall give it, as nearly as my memory will serve me, in her own words.

"I am but nineteen," she said, " a Circassian by birth, and was brought by my parents to Constantinople, and sold, at the age of nine years, to a friend of Fatma Hanoum's. I was very happy, for she was kind to me, and I thought to pass my life in her harem ; but about a year ago $I$ accompanied her hither on a visit to the wife of Mustafa Effendi, at a moment 
when her son was beside her. I was one of four; and I do not yet understand why nor how I attracted his attention as I stood beside my companions ; but a few days afterwards my mistress called me to her, and asked me if I had remarked the young Ismaël Bey when we had visited his mother. I told her that I had seen him; and she then informed me that the $\mathrm{Ha}$ noum desired to purchase me, in obedience to his wish; and demanded of me if I was willing to accede to the arrangement. Of course, I consented, and the Bey, having considered me as agreeable when I had withdrawn my yashmac as he had anticipated, he purchased me for ten thousand piastres, and 1 became an inmate of the harem of Mustafa Effendi - I am still happy," she added plaintively, " very happy, for I am sure he loves me; but I nevertheless hope to be more so ; for ere long I shall be a mother, and should my child prove to be a boy, from his Odalique I may perhaps become his wife."

I pitied the poor young creature as I listened to her narrative, through the medium of my companion, who spoke the Turkish language fluently; and I breathed a silent prayer that her. visions of happiness might be realized. She was not pretty; but she was so childlike, so graceful, and so gentle, that she inspired an interest which, when I had heard her story, was even. painful; nor was the feeling lessened by an in- 
troduction to her husband, who, during the evening, sent to desire that all the women, save his mother and wife, should retire, as he intended to visit the harem; doubtlessly as much to satisfy his curiosity, as to exhibit his courtesy, by paying his respects to the European guests of his mother. Sallow and sickly-looking, inanimate, even for a Turk, and apparently bête comme une buche, he seated himself, and listened to the conversation that was going forward, with one unvaried and inexpressive smile-

Pleased, he knew not why, and cared not wherefore;

dividing his admiration between the Frank ladies, and the brilliancy of a large diamond that he wore on his finger.

How comparative is happiness! I never lay my head upon my pillow, but I am grateful to Providence that I was not born in Turkey; while the fair Osmanlis in their turn pity the Frank women with a depth of sentiment almost ludicrous. They can imagine no slavery comparable with our's-we take so much trouble to attain such slight ends-we run about from country to country, to see sights which we must regret when we leave them-we are so blent with all the anxieties and cares of our male relations - we expose ourselves to danger, and brave difficulties suited only to men - we have to contend with such trials and temptations, from our constant contact with the opposite sex 
-in short, they regard us as slaves, buying our comparative liberty at a price so mighty; that they are unable to estimate its extent-and then, the hardship of wearing our faces uncovered, and exposing them to the sun and wind, when we might veil them comfortably with a yashmac! Not a day passes in which they have commerce with a Frank, but they return thanks to Allah that they are not European women!

A modern French traveller, whose amusing work has, in one moderate volume, contrived to treat of about a dozen countries and localities; and to detail, respecting each, such a mass of fallacies as assuredly were never before collected together: informs his readers that the jealousies of the harem are carried to such a pitch as to entail poison, or, at the least, humiliating and severe labour on the victim of the disappointed rival! This assertion, like many others in which he has indulged, would be comic were it not wicked-for the very arrangements of the harem render it impossible : each lady has her private apartment, which, should she desire to remain secluded, no one has the privilege to invade; and, from the moment that she becomes a member of the family, her life, should she so will it, is one of the most monotonous idleness. The very slaves, as I believe I have elsewhere remarked, are so numerous in every handsome establishment, that three-fourths of their time is unem- 
ployed; and as, in the less distinguished ranks, no Turk indulges in the expensive luxury of a second wife, there is little opportunity afforded for female tyranny.

The Kiära Bey, or Minister of the Interior, despite his exalted station and his immense wealth, has declined to avail himself of his polygamical privilege; and, although his wife is both plain and elderly, she has such a supreme hold, if not upon his heart, at least upon his actions, that, a short time since, having discovered that her lord had suddenly become more than necessarily attentive to a fair Circassian, her own peculiar favourite, whom she had reared from a child, and whose beauty was of no ordinary character, she very quietly placed her in an araba, sent her to the slave-market, and disposed of her to the highest bidder. The ingratitude of the protégée had loosened her hold on the affections of her patroness; nor did the husband venture to utter a reproach to his outraged helpmate, when he discovered the absence of the ton-fascinating Circassian.

Fad the unhappy girl been the Odalique of the lord, instead of the slave of the lady, the evil would have been irremediable, however; as in that case, the Bayuk Hanoum would have possessed no power to displace her.

Early in the morning, the stately Fatma Hanoum presented to my companion and myself a 
bokshalik from the venerable Effendi, which consisted of the material for a dress, neatly folded in a handkerchief of clear muslin, fringed with gold-coloured silk; and, as I made my hasty toilette, in the hope of witnessing the procession of the Baïram, and seeing Mahmoud "the Powerful" in all the splendour of his greatness, I glanced with considerable interest round the apartment in which I had passed the night. In the domed recess, which I soon discovered to be common to every handsome Turkish apartment, stood a French clock, that " discoursed," if not "eloquent," at least fairylike, music-a piece of furniture, by the way, universally popular among the natives of the East, who usually have one or more in every room occupied by the family-two noble porcelain vases-a china plate containing an enamelled snuff-box, and a carved ebony chaplet - and a tray on which were placed cut crystal goblets of water, covered glass bowls filled with delicate conserves, a silver caïque, whose oars were small spoons, and a beautifully worked wicker basket, shaped like a dish, and upheaped with crystallized fruits, sparkling beneath a veil of pale pink gauze, knotted together with bunches of artificial flowers.

Turkish hospitality and prévoyance provide even for the refreshment of a sleepless night! 
The divan was of flesh-coloured satin, and the carpet as delicately wrought and patterned as a cachemire shawl. 'The cushions which had been piled about my bed were of velvet, satin, and embroidered muslin, and the coverlets, of rich Broussa silk, powdered with silver leaves.

I made my libations with perfumed waterswallowed my coffee from a china cup so minute that a fairy might have drained it-tied on my bonnet-an object of unvarying amusement to the Turkish ladies, who consider this stiff headdress as one of the most frightful and ridiculous of European inventions - and bade adieu to Fatma Hanoum and her dark-cyed daughter, with a regret which their unbounded courtesy and kindness were well calculated to inspire.

A wealthy Armenian diamond-merchant, who held a high situation in the Mint, had offered us a window, whence we might witness the whole ceremony of the Imperial procession, and towards this point we bent our steps. But, alas for our curiosity! our leave-taking had been so thoughtlessly prolonged, that the subjects of his Sublime Highness had blocked up every avenue bearing upon the point by which he was to pass ; and, despite all the efforts of our European cavaliers and native attendants, to proceed was impossible. We accordingly took up our station a little apart from the crowd, in 
order to contemplate at our ease the novel and picturesque spectacle of a Turkish mob.

In the distance rose the gigantic dome and arrowy minarets of Saint Sophia ; and beneath them, far as the eye could reach, stretched a sea of capped and turbaned heads, heaving and sinking like billows after a storm. Every houseroof, every mouldering wall, every heap of rubbish, was covered with eager spectators; while the windows of the surrounding dwellings were crowded with veiled women and laughing children.

What groups were wedged together in the narrow space immediately before us! The pale, bent, submissive-looking Jew was folding his greasy mantle closer about him, as he elbowed aside the green-turbaned Emir, and the grave and solemn Hadje who had knelt beside the grave of the Prophet: the bustling Frank was striding along, jostling alike the serious Armenian, whose furred and flowing habit formed a strange contrast to the short blue jacket and tight pantaloons of the tall, strong-limbed, Circassian - and the bustling and noisy Greek, whose shrill voice and vociferous utterance would have suited a woman-parties of Turkish officers were forcing a passage as best they could, with their caps pulled down upon their eyebrows, their sword-belts hanging at least a quarter of a yard below their waists, and their 
diamond stars, (the symbols of their military rank) glittering in the clear sunshine-patroles of Turkish soldiers were endeavouring in vain to clear a passage along the centre of the street for the convenience of the Sultanas, and the wives :of the different Pashas, whose arabas were momently expected; the mob closing rapidly in their rear as they slowly moved onand clouds of doves at intervals filled the air, the tenants of the giant mosque before us, scared from the usual quiet of their resting-places by the unwonted stir and excitement beneath them.

As the birds which domesticate themselves about the mosques are held sacred, and regarded with almost superstitious reverence, their numbers necessarily increase to a wonderful extent; and on this occasion they hovered round the stupendous edifice of Saint Sophia, to the amount of several thousands.

A strange military difficulty had been started a short time previously to the occasion of the Baïram, which had been overcome in so extraordinary"and "even humorous a manner, that it deserves especial mention; and it was to convince myself of the actual existence of the laughable custom engendered by 'Turkish jealousy, that I remained longer than I should have otherwise been induced to do, in the immediate vicinity of a Constantinopolitan mob. Be it, however, avowed, en passant, that the - what 
shall I call them? for our European term of "lower orders" is by no means applicable to a people who acknowledge no difference of rankno aristocracy save that of office - the great mass of the population of the capital-assimilate on no one point with our own turbulent, vociferous, uncompromising, and unaccommodating mobs in Europe. Among above five thousand boatmen, artisans, and soldiers, not a blow was struck, not a voice was raised in menaceamong the conflicting interests, feelings, and prejudices, of Christians, Musselmauns, and Jews, not a word was uttered calculated to excite angry or unpleasant feeling; while I am bound to confess that a female, however fastidious, would have found less to offend her amid the crush and confusion of that mighty mass of commonly called semi-civilized human beings, than in a walk of ten minutes through the streets. of London or Paris.

The natives of the East have yet to learn that there can be either wit or amusement in annoying others for the mere sake of creating annoyance ; that there can be humour in raising. a blush on the cheek of the timid, or calling a pang to the heart of the innocent. They are utilitarians ; to torment for the mere love of mischief they do not comprehend; and they, consequently, never attempt extraneous evil unless to secure, or at least to strive for, some immediate 
personal benefit. Thus no rude or impertinent comment is made upon the Frank stranger, and above all, upon the Frank woman, whose habits, manners, and costume, differ so widely, and, doubtlessly to them so absurdly, from those of their own country; while towards each other they are as staid, as solemn, and as courteous, as though each were jealous to preserve the good order of the community, and considered it as his individual concern.

To revert to the military ceremony, from which, in order to render justice to the Turkish population, I have unavoidably digressed; I shall mention, without further preface, that it arose from the reluctance of the Sultan and his ministers, that the troops, in presenting arms to the female members of the Imperial family, should have the opportunity afforded them of a momentary gaze at their veiled and sacred countenances. The difficulty was, how to retain the " pomp and circumstance" of the ceremonial, and at the same time to render this passing privilege impossible. A most original and satisfactory expedient was at length fortunately discovered; and we were lucky enough to witness the effect of the new arrangement.

The slow and noisy rattle of the arabas was heard-the word was passed along the line that the Sultanas were approaching - and suddenly the troops faced about, with their backs to the 
open space along which the princesses were expected, and, extending their arms to their full length, the manœurre was performed behind them, producing the most extraordinary and ludicrous scene that was perhaps ever enacted by a body of soldiers! In this uncomfortable, and I should also imagine difficult, position, they remained until the four carriages had passed, when they resumed their original order, and stood leaning negligently on their muskets until the return of the Imperial cortège.

George Cruikshank would have immortalized himself had he been by to note it ! 


\section{CHAPTER VIII.}

Bath-room of Scodra Pasha-Fondness of the Eastern Women for the Bath-The Outer Hall-The Proprietress - Female Groupes-The Cooling-roum -The Great Hall-The Fountains-The Bathing Women-The Dinner-Apology for the Turkish Ladies.

The first bath-room which I saw in the country was that of Scodra Pasha; and, had I been inclined so to do, I might doubtlessly have woven a pretty fiction on the subject, without actually visiting one of these extraordinary establishments. But too much has already been written on inference by Eastern tourists, and I have no wish to add to the number of fables which have been advanced as facts, by suffering imagination to usurp the office of vision. Such being the case, I resolved to visit a public bath in company with a female acquaintance, and not only become a spectator but an actor in the scene, if $I$ found the arrangement feasible.

The bath-room of the Pasha, or rather of his family, was a domed cabinet, lined with marble, moderately heated, and entered from the loveliest little boudoir imaginable, where a sofa of bro-

VOL. 1 . 
caded silk, piled with cushions of gold tissue, offered the means of repose after the exhaustion of bathing. But I had seen it tenanted only by a Greek lady and myself, and half a score of slaves, who were all occupied in attendance upon us ; and I felt at once that, under such circumstances, I could form no adequate idea of what is understood by a Turkish bath; the terrestrial paradise of Eastern women, where politics, social and national, scandal, marriage, and every other subject under heaven, within the capacity of uneducated but quick-witted females, is discussed : and where ample revenge is taken for the quiet and seclusion of the harem, in the noise, and hurry, and excitement, of a crowd.

Having passed through a small entrance-court, we entered an extensive hall, paved with white marble, and surrounded by a double tier of projecting galleries, supported by pillars; the lower range being raised about three feet from the floor. These galleries were covered with rich carpets, or mattresses, overlaid with chintz or crimson shag, and crowded with cushions; the spaces between the pillars were slightly partitioned off to the height of a few inches; and, when we entered, the whole of the boxes, if I may so call them, were occupied, save the one which harl been reserved for us.

In the centre of the hall, a large and handsome fountain of white marble, pouring its 
waters into four ample scallop shells, whence they fell again into a large basin with the prettiest and most soothing sound imaginable, was surrounded by four sofas of the same material, on one of which, a young and lovely woman, lay pillowed on several costly shawls, nursing her infant.

When I had established myself comfortably among my cushions, I found plenty of amusement for the first half hour in looking about me; and a more singular scene I never beheld. On the left hand of the door of entrance, sat the proprietress of the baths, a beautiful woman of about forty, in a dark turban, and a straight dress of flowered cotton, girt round the waist with a cachemire shawl; her chemisette of silk gauze was richly trimmed - her gold snuff-box lay on the sofa beside her-her amber-headed pipe rested against a cushion - and she was amusing herself by winding silk from a small ebony distaff, and taking a prominent part in the conversation; while immediately behind her squatted a negro slave-girl of twelve or thirteen years of age, grinning from ear to ear, and rolling the whites of her large eyes in extacy at all that was going forward.

'The boxes presented the oddest appearance in the world-some of the ladies had returned from the bathing-hall, and were reclining luxuriously upon their sofas, rolled from head to 
foot in fine white linen, in many instances embroidered and fringed with gold, with their fine hair falling about their shoulders, which their slaves, not quite so closely covered as their mistresses, were drying, combing, perfuming, and plaiting, with the greatest care. Others were preparing for the bath, and laying aside their dresses, or rather suffering them to be laid aside, for few of them extended a hand to assist themselves - while the latest comers were removing their yashmacs and cloaks, and exchanging greetings with their acquaintance.

As I had previously resolved to visit every part of the establishment, I followed the example of my companion, who had already undergone the fatigue of an Oriental bath, and exchanged my morning dress for a linen wrapper, and loosened my hair : and then, conducted by the Greek waiting-maid who had accompanied me, I walked barefooted across the cold marble floor to a door at the opposite extremity of the hall, and, on crossing the threshold, found myself in the cooling-room, where groups of ladies were sitting, or lying listlessly on their sofas, enveloped in their white linen wrappers, or preparing for their return to the colder region whence I had just made my eseape.

This second room was filled with hot air, to me. indeed, most oppressively so; but I soon 
discovered that it was, nevertheless, a coolingroom; when, after having traversed it, and dipped my feet some half dozen times in the little channels of warm water that intersected the floor, I entered the great bathing-place of the establishment - the extensive octagon hall in which all those who do not chuse, or who cannot afford, to pay for a separate apartment, avail themselves, as they find opportunities, of the eight fountains which it contains.

For the first few moments, I was bewildered; the heavy, dense, sulphureous vapour that filled the place, and almost suffocated me-the wild, shrill cries of the slaves pealing through the reverberating domes of the bathing-halls, enough to awaken the very marble with which they were lined - the subdued laughter, and whispered conversation of their mistresses murmuring along in an under-current of soundthe sight of nearly three hundred women only partially dressed, and that in fine linen so perfectly saturated with vapour, that it revealed the whole outline of the figure-the busy slaves, passing and repassing, naked from the waist upwards, and with their arms folded upon their bosoms, balancing on their heads piles of fringed or embroidered napkins-groups of lovely girls. laughing, chatting, and refreshing themselves with sweetmeats, sherbet, and lemonade - parties of playful children, apparently quite in- 
different to the dense atmosphere which made me struggle for breath - and, to crown all, the sudden bursting forth of a chorus of voices into one of the wildest and shrillest of Turkish melodies, that was caught up and flung back by the echoes of the vast hall, making a din worthy of a saturnalia of demons - all combined to form a picture, like the illusory semblance of a phantasmagoria, almost leaving me in doubt whether that on which I looked were indeed reality, or the mere creation of a distempered brain.

Beside every fountain knelt, or sat, several ladies, attended by their slaves, in all the various stages of the operation; each intent upon her own arrangements, and regardless of the passers-by; nor did half a dozen of them turn their heads even to look at the English stranger, as we passed on to the small inner cabinet that had been retained for us.

The process of Turkish bathing is tedious, exhausting, and troublesome; I believe that the pretty Greek who attended me spent an hour and a half over my hair alone. The supply of water is immense, and can be heated at the pleasure of the bather, as it falls into the marble basin from two pipes, the one pouring forth a hot, and the other a cold, stream. The marble on which you stand and sit is heated to a degree that you could not support, were the at- 
mosphere less dense and oppressive; and, as the water is poured over you from an embossed silver basin, the feeling of exhaustion becomes almost agreeable. Every lady carries with her all the appliances of the bath, as well as providing her own servant; the inferior ranks alone availing themselves of the services of the bathing women, who, in such cases, supply their employers with every thing requisite.

These bathing-women, of whom I saw several as I traversed the great hall, are the most unsightly objects that can be imagined; from constantly living in a sulphureous atmosphere, their skins have become of the colour of tobacco, and of the consistency of parchment; many among them were elderly women, but not one of them was wrinkled; they had, apparently, become aged like frosted apples; the skin had tightened over the muscles, and produced what to me at least was a hideous feature of old age.

Having remained in the bath about two hours and a half, I began to sicken for pure air and rest; and, accordingly, winding a napkin with fringed ends about my head, and folding myself in my wrapper, I hastily and imprudently traversed the cooling-room, now crowded with company, looking like a congregation of resuscitated corses clad in their grave-clothes, and fevered into life; and gained the outer hall, 
where the napkin was removed from my head, my hair carefully plaited without drying, and enveloped in a painted muslin handkerchief; and myself buried among the soft cushions of the divan.

A new feature had been added to the scene since my departure; most of the ladies were at dinner. The crimson glow of the bath, which throws all the blood into the head, had passed from most of their faces, and was replaced by the pure, pale, peach-like softness of complexion that its constant use never fails to produce. Numbers of negresses were entering with covered dishes, or departing with the reliques of those which had been served up; and, as the Turkish mode of eating lends itself to these pic-nic species of repasts, the fair ladies appeared to be as much at home squatted round their plated or china bowls, spoon in hand, in the hall of the bath, as though they were partaking of its contents in the seclusion of their own harems.

Sherbet, lemonade, molalibè, a species of inferior blanc-manger, and fruit, were constantly handed about for sale; and the scene was altogether so amusing, that it was almost with regret that I folded myself closely in my cloak and veil, and bowed my farewell to the several groups which I passed on my way to the door.

I should be unjust did I not declare that I 
witnessed none of that unnecessary and wanton exposure described by Lady M. W. Montague. Either the fair Ambassadress was present at a peculiar ceremony, or the Turkish ladies have become more delicate and fastidious in their ideas of propriety.

The excessive exhaustion which it induces, and the great quantity of time which it consumes, are the only objections that can reasonably be advanced against the use of the Turkish bath. 


\section{CHAPTER IX.}

Cheerful Cemeteries - Burial-ground of Pera - Superiority of the Turkish Cemeteries-Cypresses-Singular Superstition-The Grand Champs-Greek Grave-yard - Sultan Selim's Barrack - Village of St. Demetrius - European Burial-ground - Grave-stones - The Kiosk-Noble View - Legend of the Maiden's Tower - Plague Hospital of the Turks-The Plague-Caïque-Armenian CerneteryCurious Inscriptions-Turkish Burial-place-Distinctive Head-stones - Graves of the Janissaries-Wild Superstition-Cemetery of Scutari - Splendid Cypresses - Ancient Prophecy - Extent of Burialground-The Headless Dead-Exclusive Enclosures-Aspect of the Cemetery from the Summer Palace of Heybetoullah Sultane Local Superstition-The Damnèd Souls.

I HAVE alluded elsewhere to the apparent care with which the Turks select the most lovely spots for burying their dead, and how they have, by such means, divested death of its most gloomy attributes. Like the ancient Romans, they form grave-yards by the roadside; and, like them, they inseribe upon their tombs the most beautiful lessons of resignation and philosophy.

The Cemetery of Pera offers a singular spectacle; and the rather that the "Champ des Morts" is the promenade of the whole population, Turk, Frank, Greek, and Armenian; the lesser burial-place, or Petit Champs, is sacred to 
the Mussulmauns, and fringes with its dark cypresses the crest of the hill that dominates the port; it is hemmed in with houses-overlooked by a hundred casements - grazed by cattle-loud with greetings and gossipry-and commands an extensive view of the shipping in the harbour and the opposite shore. There are footpaths among the funereal trees; sunny glades gleaming out amid the dark shadows; headstones clustered against the grassy slopes, and guard-houses, with their portals thronged with lounging soldiers, mocking the defencelessness of the dead. Nor must I forget to mention the small octagonal building, which, seated in the very depth of the valley, and generally remarkable from the dense volume of smoke exuding from its tall chimney, marks the spot where the last profane duties are paid to the dead; where the body is washed, the beard is shorn, the nails are cut, and the limbs are decently composed, ere what was so lately a True Believer is laid to rest in the narrow grave, to be aroused only by the sound of the last trumpet.

The superiority of the Turkish cemeteries over those of Europe may be accounted for in several ways. Their head-stones are more picturesque and various - their situation better chosen-and, above all things, the Mussulmaun never disturbs the ashes of the dead. There is no burying and re-burying on the same spot, 
as with us. The remains of the departed are sacred.

When a body is committed to the earth, the priest plants a cypress at the head, and another at the foot, of the grave ; and hence those farspreading forests, those bough o'er-canopied cities of the dead, which form so remarkable a feature in Turkish scenery. Should only one tree in six survive, enough still remain to form a dense and solemn grove; but the Turks have a singular superstition with regard to those that, instead of lancing their tall heads towards the sky, take a downward bend, as though they would fain return to the earth from whence they sprang; they hold that these imply the damnation of the soul whose mortal remains they overshadow; and as, from the closeness with which they are planted, and their consequent nnmber, such accidents are by no means rare, it must be at best a most uncomfortable creed.

But it is to the "Grand Champs" that the stranger should direct his steps, if he would contemplate a scene to which the world probably can produce no parallel. Emerging from the all but interminable High Street, whose projecting upper stories form a canopy above your head for nearly its whole length, you have on your left hand the plague-hospital for the Franks, and on your right a stretch of higher 
land, which is the burial-ground of the Greeks. Here there is nothing to arrest your steps; it is ill-kept, and, were it not for the houses that surround it, would be dreary and desolate from its very disorder. The Greek is the creature of to-day-yesterday is blotted from his tablets.

Having passed the grave-yard, the road widens into an esplanade, in front of an extensive block of building, erected by Sultan Selim as a cavalry barrack. 'It is painted rose colour, has a noble entrance, and possesses a look of order and regularity almost European. It is not until you descend the gentle declivity that slopes onward to the Grand Champs des Morts, that you discover the whole extent of the edifice, which is a quadrangle, having three fronts; its fourth side being devoted to a range of stabling.

The road to Therapia and the "Sweet Waters" skirts the burial-ground; and the little Greek village or colony of St. Demetrius covers an opposite height.

The first plot of ground, after passing the barrack, is the grave-yard of the Franks; and here you are greeted on all sides with inscriptions in Latin: injunctions to pray for the souls of the departed; flourishes of French sentiment; calembourgs graven into the everlasting stone, treating of roses and reine Marguerites ; concise English records of births, deaths, ages, 
and diseases ; Italian elaborations of regret and despair; and all the common-places of an ordinary burial-ground.

Along the edge of this piece of land, a wide road conducts you to a steep descent leading to the Sultan's Palace of Dolma Batché ; the crest of the hill commanding a noble view of the channel; while, on the verge of the descent, and almost touching the graves, stands a kiosk of wood, rudely put together, and serving as a coffee room ; and immediately in front of it, a group of cypresses form a pleasant shade, beneath which parties of Turks, Greeks, and Armenians, seated on low stools, smoke their eternal chibouks, sip their sugarless coffee, and contemplate one of the loveliest views over which the eye of a painter ever lingered.

From this height, the hill slopes rapidly downward, clothed with fruit trees, and bright with vegetation. At its foot flows the blue Bosphorus, clear and sparkling as the sky, whose tint it rivals. Immediately across the channel stretches Scutari, the gem of the Asian shore, with its forest of cypresses, its belt of palaces, its hill-seated kiosks, and its sky-kissing minarets. Further in the distance are two pigmy islands, heaving up their dark sides from the bright wave, like aquatic monsters revelling in the sunshine; beyond is a stretch of sea - the Sea of Marmora-laughing in 
the light, as though no storms had ever rent its bosom - while, above all, on the extreme verge of the horizon, almost blending with the dark purple clouds that rest upon it, towers Mount Olympus, the dwelling of the gods, crowned with snows, and flinging its long shadows over the pleasant town and mulberry groves of Broussa. And here, a little to the right, (where Scutari, after advancing with a graceful curve, as though to do homage to her European sister, again recedes), upon a rock so small that its foundations cover the whole surface, stands the "Maiden's Tower ;" an object in itself so picturesque that it would arrest the eye though it possessed no legend to attract the sympathy - but such is far from being the case.

This Tower, so runs the tale, was erected by a former Sultan, as a residence for his only daughter, of whom it was foretold by the astrologers that she would, before the completion of her eighteenth year, be destroyed by a serpent. Every precaution was taken to overcome destiny; but it was not to be - an adder, accidentally concealed in a box of figs, fastened upon the hand of the princess, and she was found dead on her sofa.

The Maiden's Tower is now the plague-hospital of the Turks : and his heart must be atrophised indeed who can look around on the 
bright and beautiful scene amid which it stands, and not feel how much the bitter pang of the plague-smitten must be enhanced by the contrast of all around them with their own probable fate-for, alas! the long gaze of the sickening victim is too frequently his last! The dying wretch should pass to his infected home by a road of gloom and shadow, where no image of gladness can mock him by its intrusive and harrowing presence-but to be swiftly borne along that blue sea, with those magnificent shores stretching away into the distance, far beyond his failing vision-to be carried to his narrow chamber, probably to die - cut off from his fellow-men-from all the glory and the majesty around him - surely no after-pang can be so keen as that which grapples at his heart during his brief voyage to the Maiden's Tower !

Rapidly darts forward the slender caïque; it shoots from the shore like a wild bird-no sound of revelry, no shout of greeting, no pealing laughter, heralds its departure - the sturdy rowers bend to their oars; the resisting waters yield before the vigorous stroke-there is no pause-no interval-the errand is contagionthe freight is death! The eyes are dim that roll languidly in their sockets: the lips are livid that quiver with agony in lieu of words: the brow is pale and clammy that is turned upwards to the cloudless sky - the hands are 
nerveless that are flung listlessly across the panting breast - and as men watch from afar the rapid progress of the laden boat, their own breath comes thickly, and their pulses throb; and, when they at length turn aside to pursue their way, they move onward with a slower and a less steady step - their brows are clouded they have looked upon the plague!

But the goal is gained, and the caiqque has discharged its gloomy freight. All around is life, and light, and loveliness. The surface of the channel is crowded with boats, filled with busy human beings, hurrying onward in pursuit of pleasure or of gain ; a thousand sounds are on the wind. The swift caïques dart like water-fowl past the Maiden's Tower, and few within them waste a thought upon the anguish which it conceals!

A few paces from the spot whence you look down upon this various scene-a few paces, and from the refuge of the dying you gaze upon the resting-place of the dead. : Where the acaciatrees blossom in their beauty, and shed their withered flowers upon a plain of graves on the right hand, immediately in a line with the European cemetery, is the burial-ground of the Armenians. It is a thickly-peopled spot; and as you wander beneath the leafy boughs of the scented acacias, and thred your way among the tombs, you are struck by the peculiarity of their invOL. $I$. 
scriptions. The noble Armenian character is graven deeply into the stone; name and date are duly set forth; but that which renders an Armenian slab (for there is not a head-stone throughout the cemetery) peculiar and distinctive, is the singular custom that has obtained among this people of chisselling upon the tomb the emblem of the trade or profession of the deceased.

Thus the priest is distinguished even beyond the grave by the mitre that surmounts. his name - the diamond merchant by a group of ornaments - the money-changer by a pair of scales-the florist by a knot of flowers-besides many more ignoble hieroglyphics, such as the razor of the barber, the shears of the tailor, and others of this class; and, where the calling is one that may have been followed by either sex, a book, placed immediately above the appropriate emblem, distinguishes the grave of the man.

Nor is this all: the victims of a violent death have also their distinctive mark-and more than one tomb in this extraordinary burialplace presents you with the headless trunk of an individual, from whose severed throat the gushing blood is spirting upwards like a fountain, while the head itself is pillowed on the clasped hands! Many of the more ancient among the tombs are very richly and elabo- 
rately wrought, but nearly all the modern ones are perfectly simple; and you seldom pass the spot without seeing groups of people seated upon the graves beneath the shadow of the trees, talking, and even smoking. Death has no gloom for the natives of the East.

The Turkish cemetery stretches along the slope of the hill behind the barrack, and descends far into the valley. Its thickly-planted cypresses form a dense shade, beneath which the tall head-stones gleam out white and ghastly. The grove is intersected by footpaths, and here and there a green glade lets in the sunshine, to glitter upon many a gilded tomb. Plunge into the thick darkness of the more covered spots, and for a moment you will almost think that you stand amid the ruins of some devastated city. You are surrounded by what appear for an instant to be the myriad fragments of some mighty whole-but the gloom has deceived you - you are in the midst of a Nekropolis-a City of the Dead. Those chisselled blocks of stone that lie prostrate at your feet, or lean heavily on one side as if about to fall, and which at the first glance have seemed to you to be the shivered portions of some mighty column - those turban-crowned shafts which rise on all sides - those gilt and lettered slabs erected beside them - are memorials of the departed-the first are of ancient date; the earth 
has become lonsened at their base, and they have lost their hold - the others tell their own tale; the bearded Moslen sleeps beside his wife-the turban surmounting his head-stone, and the rose-branch carved on her's, define their sex, while the record of their years and virtues is engraven beneath. Would you know more? Note the form and folds of the turban, and you will learn the rank and profession of the deceased - here lies the man of law - and there rests the Pasha-the soldier slumbers yonder, and close beside you repose the ashes of the priest - here and there, scattered over the burial-ground, you may distinguish several head-stones from which the turbans have been recently struck off-so recently that the severed stone is not yet weather-stained; they mark the graves of the Janissaries, desecrated by order of the Sultan after the distinction of their body; who himself stood by while a portion of the work was going forward; and the mutilated turbans that are half buried in the long grass beside these graves are imperishable witnesses to their disgrace - a disgrace which was extended even beyond the grave, and whose depth of ignominy can only be understood in a country where the dead are objects of peculiar veneration.

Those raised terraces enclosed within a railing are family burial-places; and the miniature 
column crowned with a fès, painted in bright scarlet, records the rest of some infant Effendi. At the base of many of the shafts are stones hollowed out to contain water, which are carefully filled, during the warm season, by pious individuals, for the supply of the birds, or any wandering animals.

The Turks have a strange superstition attached to this cemetery. They believe that on particular anniversaries sparks of fire exude from many of the graves, and lose themselves among the boughs of the cypresses. The idea is at least highly poetical.

But Constantinople boasts no burial-place of equal beauty with that of Scutari, and probably the world cannot produce such another, either as regards extent or pictorial effect. A forest of the finest cypresses extending over an immense space, clothing hill and valley, and overshadowing, like a huge pall, thousands of dead, is seen far off at sea, and presents an object at once striking and magnificent. Most of the trees are of gigantic height, and their slender and spiral outline cutting sharply against the clear sky is graceful beyond expression. 'The 'Turks themselves prefer the great cemetery of Scutari to all others; for, according to an ancient prophecy in which they have the most implicit faith, the followers of Mahomet are, ere the termination of the world, to be expelled 
from Europe ; and, as they are jealous of committing even their ashes to the keeping of the Giaour, they covet, above all things, a grave in this Asiatic wildnerness of tombs. Thus, year after year, the cypress forest extends its boundaries, and spreads further and wider its dense shadows; generation after generation sleeps in the same thickly-peopled solitude; and the laughing vineyard and the grassy glade disappear beneath the encroachments of the ever-yawning sepulchre - the living yield up their space to the dead - the blossoming fruit trees are swept away, and the funereal and feathering boughs of the dark grave-tree tower in their stead.

It is not without a sensation of the most solemn awe that, you turn aside from the open plain, and abandon the cheerful sunshine, to plunge into the deep gloom of the silent forest; scores of narrow pathways intersect it in all directions ; and, should you fail to follow them in your wanderings, your every step must be upon a grave. Here a group of lofty and turban-crowned columns, each with a small square slab of stone at its base, arrests you with a thrill of sickening interest, for that silent and pigmy slab tells you a tale of terror - each covers the severed head of a victim to state policy, or state intrigue-Vizirs and Pashas, Beys and Effendis - the eye that blighted, and 
the brow that burned, are mouldering, or have. mouldered there-the fever of ambition, the thirst of power, the wiliness of treason, and the pride of place - all that frets and fevers the mind of man, is there laid to rest for ever-and the stately turban towers, as if in mockery, above the trunkless head which festers in its dishonoured grave!

Those gilded tombs enclosed within their circling barrier are inscribed with the names and titles of some powerful or wealthy race that has carried its pride beyond the grave, and not suffered even its dust to mingle with that of more common men - the prostrate and perished columns on one hand have yielded reluctantly to time, and now cumber the earth in recordless ruin; while the stately headstones on the other, yet bright with gilding, and elaborate with ornament, point out to you the resting-places of the newly dead-the pomp of yesterday speaks far less sadly to the heart than the hoar and letterless remains of by-past centuries.

Suddenly a bright light flashes through the gloom; the warm sunshine falls in a flood of radiance, the more startling from the darkness that surrounds it, upon a limited and tree-less space, on which time or the tempest have done their work; and where withered boughs and shivered trunks, branchless and gray with moss, 
are prostrate among sunken tombs and ruined monuments.

Your spirit is oppressed, your eye is blinded, by that mocking light!

Here and there, upon the borders of the forest, a latticed pavilion of the brightest green, contrasting strangely with the cold, white, spectral-looking head-stones which it overtops, causes you to turn aside almost in wonder; but death is even there-it is the tomb of some beloved child, and the slab within is strown with flowers-flowers that have been gathered in anguish, and moistened with tears. Alas! for the breaking heart and the trembling hand that strewed them there!

I remember nothing more beautiful than the aspect of the burying-ground of Scutari, from the road which winds in front of the summer palace of the Princess Haybetoullah. The crest of the hill is one dense mass of dark foliage, while the slope is only partially clothed with trees, that advance and recede in the most graceful curves; and the contrast between the deep dusky green of the cypresses, and the soft bright tint of the young fresh grass in the open spaces between them, produces an effect almost magical, and which strikes you as being more the result of art than accident, until you convince yourself, by looking around you, that it is to its extent alone that this noble cemetery 
owes its gloom, for its site is eminently picturesque and beautiful. On one side, an open plain separates it from the channel; on the other, it is bounded by a height clothed with vines and almond trees - the houses of Scutari touch upon its border, and even mingle with its graves in the rear, while before it spreads a wide extent of cultivated land dotted with habitations.

Need I add that the Nekropolis of Scutari, such as I have described it, has also its local superstition? Surely not; and the idea is so wild, and withal so imaginative, that I cannot pass it by without record.

Along the channel may be constantly seen clouds of aquatic birds of dusky plumage, speeding their rapid flight from the Euxine to the Propontis, or bending their restless course from thence back again to the Black Sea, never pausing for a moment to rest their weary wing on the fair green spots of earth that woo them on every side; and it is only when a storm takes place in the Sea of Marmora, or sweeps over the bosom of the Bosphorus, that they fly shrieking to the cypress forest of Scutari for shelter ; and these the Turks believe to be the souls of the damned, who hare found sepulchre beneath its boughs, and which are permitted, during a period of elementary commotion, to revisit the spot where their mortal bodies moulder; and 
there mourn together over the crimes and judgment of their misspent existence upon earthwhile, during the gentler seasons, they are compelled to pass incessantly within sight of the localities they loved in life, without the privilege of pausing even for one instant in the charmed flight to which they are condemned for all eternity!

My mind was full of this legend when I visited the cemetery-and I can offer no better apology for the wild verses that I strung together as I sat upon a fallen column in one of the gloomiest nooks of the forest, and amid the noon-day twilight of the thick branches, while my companions wandered away among the graves.

\section{THE DAMNÈD SOULS.}

Hark! 'tis a night when the storm-god rides

In triumph o'er the deep;

And the howling voice of the tempest chides

The spirits that fain would sleep:

When the clouds, like a sable-bannered host,

Crowd the dense and lurid sky;

And the ship and her crew are in darkness lost

As the blast roars rushing by.

Voices are heard which summon men

To a dark and nameless doom ;

And spirits, beyond a mortal's ken,

Are wandering through the gloom; 
While the thunders leap from steep to steep, And the yellow lightnings flash, And the rocks reply to the riot on high, As the wild waves o'er them dash.

And we are here, in this night of fear,

Urged by a potent spell,

Haunting the glade where our bones are laid,

Our tale of crime to tell-

We have hither come, through the midnight gloom,

As the tempest about us rolls,

To spread mid the graves, where the rank grass waves,

The feast of the Damned Souls.

Some have flown from the deep sea-caves

Which the storm-won treasures hold;

And these are they who through life were slaves

To the sordid love of gold ;

No other light e'er meets their sight,

Save the gleam of the yellow ore ;

And loathe they there, in their dark despair,

What they idolized before.

They have swept o'er the rude and rushing tide,

Bestrown with wreck and spoil,

Where the shrieking seaman writhed and died

'Mid his unavailing toil ;

And they rode the wave, without power to save

The wretch as he floated by;

And sighed to think, as they saw him sink,

What a boon it was to die!

Some were cast from the burning womb,

Whence the lava-floods have birth;

From fires which wither, but ne'er consume

The rejected one of earth - 
And these are they who were once the prey

Of the thirst that madmen know,

When the world for them is the diadem

That burns into the brow.

They who crouch in the deepest gloom

Where no lightning-flash can dart,

Who, chained in couples, have hither come,

And can never be rent apart ;

These are they whose life was a scene of strife, And who learnt, alas! too late,

That the years flew fast which they each had cast On the altar of their hate.

But, hark! through the forest there sweeps a wail More wild than the tempest-blast,

As each commences the darkiing tale

Of the stern and shadowy past-

And the spell that has power, in this dread hour,

No pang of our's controls -

Nor may mortal dare in the watch to share

That is kept by the Damnèd Souls! 


\section{CHAPTER X.}

Character of the Constantinopolitan Greeks-The Greek Colony at the Fanar - Vogoride, Logotheti, and Angiolopolo-Political SentimentChateaubriand at the Duke de Rovigo's - Biting Criticism-Greek Chambers-"What's in a Name?"-Custom of Buruing Perfunes The Pastille of the Seraglio-Turkish Cosmetics-Eastern Beauty.

The more I saw of the Greeks, the more curious did I find the study of that page of the great volume of human nature which was there flung back; and, far from sharing in the astonishment of those who almost deem it a miracle that the whole nation has not been swept away, I rather marvel at the state of moral and political thraldom in which they exist. The tolerated citizens of an Empire whose interests, both civil and religious, differ so widely from their own, the Fanariote Greeks nourish in their heart's core a hatred of their masters as intense as it is enduring, and serve them rather from fear than zeal.

Every Greek is an intuitive diplomatist; nature has endowed him with a keen and subtle spirit - a power to see deeply, and to act promptly-and as their motto is palpable to all 
who have studied their character - tempora mutantur, et nos mutamur in illis - they are any thing but safe counsellors or firm friends. Each is to be had at a price: and, as several of the most talented among them are in the confidence of the leading members of the Turkish government, it were idle to expatiate on the pernicious consequences of their influence. There are so many spies in the camp-so many breaches in the fortress-and, with the helm of affairs, although not actually in their grasp, at least sufficiently within their reach to enable them occasionally to make the vessel of state policy swerve towards the course whither they would fain direct it, they are no contemptible allies to any foreign power that may need their services. The Turk probably possesses the soundest judgment, but the Greek is more subtle and quick-witted, and dazzles even where he may fail to convince.

Under these circumstances, partially trusted by the 'Turks, and enriched and employed by other nations - gifted with subtlety, energy of character, and that keenness of perception and quickness of intellect for which they are remarkable-the Greeks would be dangerous, if not fatal enemies to their Moslem masters, had they not, like Achilles, one vulnerable point they are not true, even to each other. Dissimulation is the atmosphere in which they live- 
jealousy is the food on which they prey - and, while they are urging on the chariot of their own fortunes, they are sure to have some luckless rival impaled upon one of the spokes of its uncertain wheel.

Hence, all those overwhelming revolutions which render the tenure of wealth and honours among them almost as precarious as among the Turks themselves. The tolerance of the Sultan's government has conceded to them a magistracy and an ecclesiastical power as distinct as though they were a free people and the denizens of a free country ; and their shrewd and subtle spirits, trammelled without, become tenfold more bitter in their concentrated struggle for supremacy among themselves.' Their circle is limited: their hemisphere will afford space for one luninary only; to aggrandize one, another must be sacrificed; and thus it is a perpetual grappling for ascendency; and public probity and private friendship give way before it.

The Greek colony at the Fanar is the focus of intrigue; each is a spy upon his neighbour-here "Greek meets Greek," and the "tug of war" is deadly. Patriarchs and archbishops are deposed and exiled-magistrates are displaced and banished, as one or the other party obtain power - until the concentration of hatred atrophises every heart, and the smile upon every lip waits but the opportunity to wither into a snecr. 
With the double impulsion of honour and power among their own community, and wealth and influence without, it will be readily understood that a people constituted like the Fanariote Greeks pursue their purpose with a tenacity that blinds them to all less absorbing considerations. Each suffices to himself - he is his own world - and he centres all his energies and exertions upon one point. In this fact exists the weakness of the Greeks - they are too egotistical to be dangerous - they indulge individual selfishness when they should exert themselves for the common benefit of the community - the fruit is perished at the core, and it consequently decays upon the surface and, while they thus make war upon each other, and fling the brand of jealousy upon the hearths of their own race, they require no exterior force to crush them.

The three most conspicuous individuals now left among the Fanariote Greeks are Vogorede, Logotheti, and Angiolopolo, each of whom is more or less in the confidence of the Porte. The war between these talented and ambitious men is literally a war of wits. The craft is with Vogorede, the energy with Logotheti, and the tenacity of purpose with Angiolopolo. The nature of each individual is written on his countenance that of Vogorede changes like the hue of the camelion; he is a man whose smile is not mirth, nor 
approbation, nor enjoynent-his brow is narrow and deeply interlined, less by time than by the workings of his spirit; his eye is cold and quick, but it is the quickness which gives no token of intelligence-the restlessness of suspicion.

The personal attributes of Logotheti are of a different character; his glance is searching and fiery, his features mobile and expressive, and his forehead high and strongly marked; and to these no more striking contrast can be afforded than by the truly magnificent head of Angiolopolo. 'There is not a vestige of passion, not a trace of anxiety, nor care, nor emotion percepceptible; his countenance is calm, benevolent, and beautiful: his brow is singularly smooth for his age, and its character of placidity has continued unchanged throughout a long life of political exertion and excitement; while the white beard, which he wears to the utmost length that is now permitted, (Sultan Mahmoud having lately regulated this important point. and having even curtailed the exuberance of that of one of his ministers with his own Imperial hands!) gives him an air of patriarchal dignity in excellent keeping with his strictly Oriental costume.

Having been for twelve years Chargéd'Affaires at Paris during the reign of Napoleon, he has a memory stored with anecdote; and a vivacity of expression, and an accuracy of detail, which voL. I. 
make his portraits life-like, and never fail to point the moral of the tale. He discourses fluently in French, and enters into the most trifling subjects with a relish and gaiety quite wonderful when his age (near seventy) and his pursuits are taken into consideration; and you have not been half an hour in his society before you feel the greatest surprise that the maladie de pays should ever have been sufficiently strong to induce him to solicit his recall from a court whose now time-worn recollections yet retain so bright a hold upon his nature. Angiolopolo has neither the appearance nor the bearing of a veteran politician; and, were you ignorant of his history, you would look upon him:as one who had fallen into "the sear and yellow leaf," without one storm to hasten the decay.

After an existence of political toil, Angiolopolo has ostensibly retired into the calm and quiet of domestic life. I speak, therefore, of him rather as he was a few months back than as he now actually is; though the fire which has been long burning requires time ere it can be thoroughly extinguished, and it is only fair to infer that, after so many years of state service, Angiolopolo will carry with him the same tastes and pursuits to the grave.

Prepossessed by his appearance, I accepted with pleasure an invitation to spend the day with his family, and the more particularly as I 
was anxious to make the acquaintance of all those individuals who had become matter of local interest.

When I entered, he was seated in the Oriental fashion on a corner of the sofa, with a small writing-stand on a low stool beside him, and leaning his arm upon a chest of polished wood containing papers. He received us with much politeness, and presented me to his wife and daughter, who were nestled under the covering of the tandour, on the other side of the apartment, and who welcomed me in the most cordial manner.

For a time, nothing but the veriest commonplace was uttered by any of the party; but some political allusion having been accidentally made, he expressed himself both disappointed and annoyed at the supineness of the British Government, though he admitted that it had caused him no surprize, as it was not the first occasion on which England, after amusing and deluding: the Porte with promises of protection and support, had failed to fulfil her pledges in the hour of need. "As individuals," he added emphatically, "no one can-respect the English more than I do, but as a nation every thinking man throughout the Ottoman Empire has lost faith in them - the trust and confidence which the Turks once placed in the political integrity of Great Britain are at an end for ever." 
As he was an invalid, we dined en famille; and $I$ was struck with the extreme attention and deference that he showed towards his wife; all the other Greeks with whom I had become acquainted being the most indifferent, or, as we style it in Europe, the most fashionable of husbands; nor was I less surprised at the apparent zest with which he entered into the inconsequent conversation that ensued, and the playfulness with which he bandied jest for jest, and piled anecdote on anecdote. One incident that he mentioned I may repeat without indiscretion, as it cannot, after such a lapse of time, affect the individual who is its subject, and whose literary reputation is now too well established to be injured by the old-world histories of the past.

- Angiolopolo was one day dining at the table of the Duke de Rovigo, when the work of Chateaubriand on the East became the subject of conversation; the author himself, then a very young man, and butlittle known in the world of letters, being one of the guests; and, while it was under discussion, the Duke requested of Angiolopolo to give him his opinion on its merits. 'The Ottoman Chargé d'Affaires, aware that Chateaubriand was present, and not wishing to pronounce a judgment that must be displeasing to him, carelessly replied that he remembered having met with the work some 
time previously : and thus sought to turn aside the subject, the more particularly as, not being supposed to be aware of the vicinity of the author, he had no apology afforded him on the score of delicacy, should he pronounce an opinion tending to gloss over his real sentiments.

But this indefinite reply did not satisfy the Duke, who expressed his astonishment that a native of the country of which the work treated should feel so little interest in the subject as to retain no memory of its contents. 'Thus urged, Angiolopolo found himself compelled to declare that he had not only read the book carefully, but still retained the most perfect recollection of many of its passages; and that he had evaded the inquiry simply from a disinclination to speak with severity of a writer, who had permitted himself to describe the domestic manners of a people, of whom he had only been enabled to judge from such specimens as coffee-houses and the like places of vulgar resort had offered to his observation.

That he should form erroneous opinions of the mass from these low-bred and low-minded portions of the population might be pardoned, as the error of a surface-scanning and light-headed traveller; but that he should put them forth in sober earnestness to mislead wiser men, who did not possess the opportunity of forming a more 
correct judgment for themselves, was a graver and a more reprehensible fault, and one which no native of the East could easily forgive. Had he been honest, he would frankly have acknowledged that the doors of the higher classes were reluctantly and rarely opened to the Franks, who required the best introductions to secure an entrance into any distinguished house; both the habits and the position of the Orientals being unfavourable to the curiosity of strangers -and not have libelled a people of whom he really knew as little on his return to Europe as the day on which he landed at Stamboul.

"Chateaubriand has since become a distinguished writer ;" he added in conclusion, . " but I doubt not that often, amid his success, he has "emembered the dinner at the Duke de Rovigo's, and his inexorable critic."

In anecdotes of this description, in which his powers of memory and his natural vivacity were equally apparent, the hours passed rapidly away; nor did we retire till near midnight, and even then more as a matter of expediency than of weariness, (for he was far too hospitable to suffer us to leave him until the following day,) and we had consequently full time to enjoy his reminiscences.

I should have previously remarked that the chambers in the Greek houses are generally arranged in the same manner as those of the 
Turks - that is to say, a pile of mattresses are heaped upon the floor, without a bedstead; but with the Greeks the coverlets are less splendid, and the pillows are less costly. In each, a tray is conspicuously set out with conserves, generally strongly impregnated with perfume, such as rose, bergamotte, and citron : and covered goblets of richly-cut crystal, filled with water. 'The custom appears singular to an European, but it is by no means unpleasant; and I had not been long in the country ere I found the visit of the servant, who knelt down at my bedside, and handed the tray to me on my awaking, a very agreeable one.

"What's in a name ?" asks Juliet. I confess that to me there is a spell in many; and among the Greeks I did not enjoy my sweetmeats the less that they were handed to me by Euphrosine or Anastasia; or my coffee that the tray was held by Demetrius or Theodosius. This may be folly, but it is not the less fact.

The custom of burning perfumes in the mangal is, if not a healthy, at least a very luxurious one; and the atmosphere of the saloon of Angiolopolo was heavy with ambergris and musk. I have not yet met with a native of the East, of either sex, who was not strongly attached to their use; their own perfumes are delicate and agreeable, being rather concentrated preparations, than individual scents; and soothing. 
rather than exciting, the nerves; but they are also very partial to those of Europe, and among the latest presents of the Empress of Russia to the Princess Asmé, the Sultan's eldest sister, were several cases of Eau de Cologne.

The pastille of the seraglio, of which a large quantity has been presented to me by different Turkish and Armenian gentlemen, is a delightful invention ; and looks, moreover, in its casing of gold leaf, extremely elegant; as it is somewhat costly, it is not in common use, but it is greatly prized in the harems.

Perhaps no country exceeds 'Turkey in the variety and value of its cosmetics; and, although there are no daily prints to advertise their virtues, no ingenious puffs to expatiate on their properties, the ladies are by no means ignorant of their existence, but employ them in all their varieties; from the dye with which they darken their eyebrows, to the henna that disfigures the extremities of their fingers.

Among the fair Greeks, the use of rouge is by no means uncommon; and they also carry to a greater extreme than the Turkish women the frightful custom of joining the eyebrows artificially across the nose, by which mistaken habit $I$ have seen many a really pretty face terribly disfigured. I am, however, bound to confess that the dearth of beauty among the 
Greek ladies is very striking; their expression is good, but their features are irregular, and ill-assorted; and, were it not that they have almost universally fine, sparkling, dark eyes, they would be, taking them collectively, a decidedly plain race.

1 looked in vain for the noble, calm, and peculiar outline which we are prone to believe must characterize the whole people; for the finely-poised head, the expansive brow, the drooping eyelid, and, above all, the straight nose and short upper lip of genuine Grecian beauty ; I met with it only in one instance, but that one was a breathing model of the beautiful and classical in nature.

The Greek ladies are bad figures, are by no means gifted either as to hands or feet, walk ungracefully, and are remarkable only, as I have already stated, for their bright eyes, and their dark, lustrous hair.

The men are a much finer race, or rather there are more individuals among them who have the distinguished outline of head which one looks to meet with in their nation; but the females have neither the sweet, sleepy, fascinating expression of the Turkish beauties, nor the pure, fresh, sparkling complexion of the Armenian maidens, whose foreheads are frequently as snowy as the veil that binds them, and whose lips and cheeks look like crushed roses. 
Not the least lovely among them is the fair girl who, in a spirit of frolic, consented to be presented to an English traveller, (Mr. Auldjo) as a Turkish lady, but whose style of beauty is perfectly dissimilar from that of the nation which she personated; the dark eyes, the henna-tipped fingers, and the costume, which is essentially the same as that of the harem, were, however, quite sufficient to deceive an unpractised eye; and the lively Armenian, to whom I was introduced at my express desire, tells the tale of her successful deceit with a self-complacency and enjoyment perfectly amusing.

Had she more mind, and less enbompoint, an Armenian beauty would be perfect: 
THE KOURBAN-BAÏRAM.

\section{CHAP'TER XI.}

The Kourbau-Baïram - Puliteness of Mustafa Effendi - Depressing Recollections-Unquiet Night-Midnight Marclı-Turkish CoffeeA Latticed Araba-The Mosque of Sultan Achmet-Beautiful coup d'œil-Dress of the Turkish Children-Restlessness of the FranksThe Festival of Sacrifice - Old Jewish Rite - The Turkish WifeSun-rise - Appearance of the Troops - Turkish Ladies-Group of Field Officers - The Sultan's Stud - Magnificent Trappings - The Seraskier Pasla - The Great Officers of State - The ProcessionThe Sultan-Imperial Curiosity-The Chèik-Islam-Costume of the Sultan-Japanese Superstition-Vanity of Sultan Malmoud - The Hairdresser of Halil Paslra-Rapid Promotion-Oriental Salutations -Halil Pasla-Saïd Pasha-Unruly Horses-The Valley of the "Sweet Waters" "-Pera.

Tye Kourban-Baïram being fixed for the 28th of March, we crossed over to Constantinople on the evening of the 27 th, in order to be on the spot, and thus diminish the fatigue of the morrow. Mustafa Effendi, who had removed with his harem to his country-house, very obligingly offered us the use of his mansion for the night, as well as the services of his house-steward and a couple of servants; and we accordingly found ourselves once more at home beneath his hospitable roof.

I rejoiced that we required the accommodation only for some hours; as perhaps there are 
few things more depressing than a stroll through the empty and echoing chambers that you have associated with ideas and memories of mirth, and inhabitation, and amusement. The spacious apartments gave back a hollow reverberation, as we wandered over their uncarpeted floors, and flung open the casements of their uncurtained windows. The very chambers which had been purposely and carefully prepared for us were new and strange, being in a different part of the house from that occupied by the harem; and I more than once regretted the absence of the courteous old man who had received me so kindly on my first visit.

As I had failed to obtain a view of the procession at the Festival of the Baïram, that terminated the Ramazan, when an apartment had been prepared for us at the Mint, of which we were unable to take possession, owing to the density of the crowd, that filled every street in its neighbourhood, and which we were not sufficiently early to precede; I was the more anxious not to subject myself to a similar disappointment on the present occasion; a feeling that was, indeed, shared by the whole party; and, accordingly, on parting for the night, which we did at an early hour, we were very sincere in our reciprocal promises to be hyper-diligent on the morrow.

And what a night we passed! The cannon 
was booming along the water, and rattling in long-sustained echoes among the hills-the myriad dogs that infest the city, scared from their usually quiet rest, were howling, whining, and barking, without a moment's intermission ; and the Imperial band was perambulating the streets, attended by flambeau-bearers; and executing, with admirable precision, some noble pieces of music. The wind-instruments were relieved at intervals by the drums and fifes, than which there are, perhaps, none better in the world: and these were succeeded by the tramp, beneath our window, of the whole garrison of the city, afoot and under arms two hours before. daybreak.

I watched the troops as they passed, the flaring torches throwing them into broad light between the two lofty white walls that hemmed in the narrow strect, and from whose surface the sickly moonlight was fast waning, scrambling up the steep hill upon whose rise the house is built, rather in masses than in columns ; officers and men mingled pell-mell, laughing, talking, and struggling over the rough pavement, in a manner much more picturesque than imposing.

I had scarcely thrown myself once more upon my sofa, in order to court the sleep of which I had as yet only dreamt, when the rattling of our heavy carriage into the court-yard, and the 
loud knock at the door by which the Greek waiting-maid announced her wish for admittance, dispelled my hopes once more; and when she entered, candle in hand, I resigned myself to my fate, and, having ascertained that it was nearly four o'clock, made a hasty toilette, and joined my companions.

The warmest and strongest of coffee was scon swallowed - by the way, what a sad pity it is that we know nothing about making coffec in Europe-and having settled ourselves comfortably in our well-cushioned araba, Madame -—, myself, and our attendant were soon jolting over the rough pavé towards the scene of action, followed by my father and the two Turkish servants. The lattices of the carriage were closely shut, to avoid any possible difficulty, owing to our being Europeans; and one servant walked close beside each door, as though guarding the harem of some bearded Moslem.

Arrived within the precincts of the court of Sultan Achmet's magnificent mosque, and fairly entamés among the carriages, which resembled a bed of scarlet and yellow poppics, we removed the lattices altogether, and remained lying very. comfortably among our silken cushions, with the araba open on all sides, and immediately in front of us the space along which the procession was to pass : the line of carriages forming one bound- 
ary, and the other being guarded by a treble rank of military.

The coup-d'œil was beautiful! The sun was just fringing the fleecy clouds with a glad golden edge; and, as the vapours rolled away, the bright blue of the laughing sky spread far and wide its stainless canopy. The noble trees that overshadow a portion of the enclosure were just putting forth their young spring leaves, all fresh, and dewy, and tender-tokens of that infant vegetation which may be blighted by too rude a blast, and which awakens in the heart such gentle and such fond associations - the spacious steps of white marble that stretch far in front of the principal entrance of the mosque were crowded with human beings-the exterior gallery that runs along the side of the edifice on which the Sultan was to pass was filled with women, whose white veils and dark feridjhes made them look like a community of nuns-while, in the rear of the military, groups were every where forming, shifting, and producing the most interesting pictorial effects.

Here, it was a party of Jews-there, a knot of Armenians-further on, a circle of Greeks-and close beside us a cluster of women huddled together, and holding by the hand their rosy children, whose appearance I cannot more appropriately describe than by comparing them to the sweeps on May-day - such costumes! 
such pinks, greens, reds, and yellows, each outglaring the other on the girls; the most grotesque prints fashioned into the most outré forms - pendent sleeves, trailing anterys, and little curly heads enveloped in painted handkerchiefs: while the boys from three years of age figured in surtout coats as brightly buttoned, and as ill-cut as those of their fathers-miniature pantaloons, corded with scarlet - and minute fez's, with their purple tassels attached by stars of pearl of great beauty, or decorated with magnificent brilliant ornaments, fastened to the cap with pearl loops, to which were generally added golden coins, blue beads, and other preservatives against the Evil Eye!

A few Franks were distinguishable among the crowd ; but they appeared and disappeared like wandering spirits, never resting long on the same spot, and earning many a quiet smile from their Moslem neighbours, who are never weary of marvelling at the perpetual locomotion of the Giaours, so opposed to their own love of rest and quiet. Give a Turk a moderately good position on such an occasion as this, and he will never abandon it on the bare possibility of procuring a better; but the Greek and the European firlget and fuss to the last moment, and very probably do not always profit by their pains.

The Kourban-Baïram, or festival of sacri- 
fice, differs from that which takes place at the conclusion of the Ramazan, by its greater pomp and the circumstance that, on the occasion of the present festival, animals are sacrificed to propitiate the favour of the Divinity: and, as we drove along the streets, they were crowded with sheep and lambs about to be offered up.

Every head of a family sacrifices an animal with his own hands ; and every male member of his household is at liberty to indulge his piety in a similar manner; but the chief of the house is bound to observe the ceremonial.

On his return from the Mosque, the Sultan puts on a sacrificial dress, and, while two attendants hold the lamb which is to be honoured by suffering the stab of the Imperial knife, he slaughters it with his Sublime hands. The first victim that he destroys is a propitiation for himself, but he afterwards offers up one for each nember of his family, and consequently his office is by no means a sinecure.

Nor is this the only occasion on which this ancient Jewish rite is observed by the Turks. On recovery from a severe illness, on the birth of a child, on return from a pilgrimage - in short, in every leading circumstance of his life, the Musselmaun immolates a victim: but the Kourban-Baïram is the great sacrificial anniversary, and is observed with much splendour and rejoicing by all the population of the capital.

vOL. 1. 
The vessels in the harbour are gaily decked out? with flags ; all business is suspended ; men grasp each other by the hand in the streets, and utter a fraternal greeting - and the poor are seen hastening from house to house to secure the flesh of the: sacrifices, which is divided among themselves and the dogs of the city, scarcely less sacred than their own kind in the eyes of the Osmanlis:

A friend of mine was told the other day by a Turk with whom he is intimate, and who had just returned to Stamboul after an absence of six months, that he had ascertained that while he was away from home his wife had not once quitted the house; a piece of intelligence which so rejoiced him, that he had sacrificed six sheep, one for each month, in gratitude to Allah and the Prophet, who had bestowed on him so virtuou's a helpmate.

-What a glorious burst of light flooded the enclosure when the sun at length olomb the horizon! It was not only a time of human festival, but nature's own peculiar holyday; and there was an elasticity and balminess in the air that swept through the carriage, which made the heart leap for gladness.

The troops presented a better appearance in line than I had expected, but Sultan Mahmoud has yet much to do if he ever intends to make them look' like soldiers. 'They are dirty, slouch- 
ing, and awkward ; tread inwards from their habit of sitting upon their feet, and march as though they were dragging their slippers after them. The frightful fèz is pulled down to their very eyebrows, and the ill-cut clothing is composed 'of the coarsest and dingiest materials.

But what shall I say of the officers?' How shall I describe the appearance of the gallant individuals who were constantly passing and repassing, and making frequent pauses in our immediate vicinity; incited thereto, as I have no doubt, by the presence of two lovely young Turkish ladies, who had quitted their carriage, and established themselves on the footboard behind, in order to secure a better sight of the "Brother of the Sun," whom we were all anxiously awaiting; and whose yashmacs were so gracefully, or shall I say coquettishly, arranged, that I doubt whether they would have been so attractive without them. They were of the whitest and clearest muslin, through which I not only saw the flowers that rested on their foreheads, and the diamonds that sparkled in the embroidered and richly-fringed handkerchiefs bound about their heads, but even the very colour of their lips. And then the magic of their long, sleepy, jet-black eyes, and the constant flinging back and refolding of the jealous feridjhe, by fingers white, and slender, and 
henna-tipped! I really pitied the sword-girt Moslems.

I was still gazing at these lovely women, when a party of about thirty field-officers passed the carriage, on their way to their places near the door of the Mosque, at which the Sultan was to enter. They were all similarly attired in surtout coats of Spanish brown, gathered in large folds at the back of the waist, and buttoned beneath a cloth strap; a very common and ugly fashion among the Turks; and wore sword-belts richly embroidered with gold. Many among them were some of the stoutest men I ever saw.

In about five minutes after them, arrived the. led horses of the Sultan; and these formed by far the most splendid feature of the procession ; they were ten in number, and wore on their. heads a panache of white and pink ostrich: feathers mixed with roses, and fastened down upon the forelock with a clasp of precious stones. Each was attended by a groom, controlling, with some trouble, the curvettings and capers of the pampered animals, who were caparisoned in a style of splendour which, if it have ever been equalled, can certainly never have been surpassed. Their housings, which were either of silk or velvet, all differing the one from the other, were embroidered with gold 
and silver, large pearls, and jewels. One of them bore, on a ground of myrtle-coloured velvet, the cypher of the Sultan wrought in brilliants, and surrounded by a garland of flowers formed of rubies, emeralds, and topaz. Another housing, of rich lilac silk, was worked at the corners with a cluster of musical instruments in diamonds and large pearls, and, as the sunshine flashed upon it, it was like a blaze of light. The remainder were equally magnificent; and the well-padded saddles of crimson or green velvet were decorated with stirrups of chased gold, while the bridles, whose embroidered reins hung low upon the necks of the animals, were one mass of gold and jewels.

The Sultan's stud was succeeded by the Seraskier Pasha in state, mounted on a tall gray horse, (whose elaborate accoutrements were only inferior to those that I have attempted to describe,) and surrounded and followed by a dozen attendants on foot: his diamond-hilted sword - the rings upon his hands - the star in front of his fèz, and the orders on his breast, were perfectly dazzling.

At intervals of about a minute, all the great officers of state passed in the same order, and according to their respective ranks; and at length we heard the welcome sounds of the Imperial band, which struck up the Sultan's Grand 
March, as Mahmoud the Powerful, the Brother of the Sun, and Emperor of the East, passed the gates of the court.

First came twelve running footmen, in richly laced uniforms, and high military caps; and these were succeeded by the twenty body pages, who were splendidly dressed, and wore in their chakos, plumes, or rather crêtes of stiff feathers, intermixed with artificial flowers of immense size, and originally invented to conceal the face of the Sultan as he passed along, and thus screen him from the Evil Eye! But his present Sublime Highness is not to be so easily scared into concealment, and the pages. who were wont to surround his predecessors merely precede him, while a crowd of military officers supply their place, one walking at each of his stirrups, and the rest a little in the rear.

As this was the first occasion on which I had seen the Sultan, I leant eagerly forward upon my cushions to obtain a good view of him; and I saw before me, at the distance of fifteen or twenty yards at the utmost, a man of noble physiognomy and graceful bearing, who sat his horse with gentlemanlike ease, and whose countenance was decidedly prepossessing. He wore in his $f e ̀ z$ an aigrette of diamonds, sustaining a cluster of peacock's feathers; an ample blue cloak was flung across his shoulders, whose collar was one mass of jewels, and on the third 
finger of his bridle hand glittered the largest brilliant that I ever remember to have seen.

As he moved forward at a foot's pace, loud shouts of "Long live Sultan Mahmoud!" ran along the lines, and were re-echoed by the crowd, but he did not acknowledge the greeting, though his eyes wandered on all sides, until they fell upon our party, when a bright smile lit up his features, and for the first time he turned his head, and looked long and fixedly at us. 'In the next instant, he bent down, and said something in a subdued voice to the officer who walked at his stirrup, who, with a low obeisance, quitted his side, and hastily made his way through the crowd, until he reached our carriage, to the astonishment and terror of a group of Turkish women who had ensconced themselves almost under it ; and, bowing to my father, who still stood bareheaded beside us, he inquired of one of the servants who I was and what had brought me to Constantinople; the Sultan, meanwhile, looking back continually, and smiling in the same goodhumoured and condescending manner.

The reply was simple - I was an Englishwoman, and had accompanied my father to Turkey, for the purpose of secing the country ; and, having received this answer, the messenger again saluted us, and withdrew.

A very, short interval ensued ere he returned, 
and hurriedly and anxiously resumed his inquiries, to which our attendant became too nervous to reply; when he exclaimed, "Is there no one here who can act as Dragoman, and give me the intelligence which is required by his Sublime Highness?"

"I will inform you of all that you require to learn, Effendim ;" said my companion in her soft, harmonious, 'Turkish : " the lady is English."

"His Highness sees that she is English ;" replied the officer: "but he wishes to know who she is."

This important information was added, and once more he departed.

Crowds of decorated individuals closed the procession; and in five minutes more Sultan Mahmoud dismounted and entered the Mosque.

The Chëik-Islam, or High Priest, had preceded his Imperial Master; but we saw him only at a distance as he ascended the marble steps that I have already mentioned, and passed in through the great entrance. He wore a turban of the sacred green, about which was wound a massive chain, or rather belt, of gold ; and was mounted on a fine Arabian, whose bridle was held by two grooms.

Sultan Mahmoud is not a handsome man, and yet it is difficult to define wherefore ; for his features are good and strongly marked, and his eye bright and picrcing. His jet black hair, seen in 
heavy curls beneath the fèz, which, like most of his subjects, he wears drawn down low upon his forehead; and his bushy and well-trimmed beard, add considerably to the dignity of his appearance, as well as giving to him a look of much greater youth than he can actually boast; but this is a merely artificial advantage, being the effect of one of those skilful dyes so common in the East.

As in Japan, the popular belief is firm that the King never dies, so in Turkey the Sovereign is never permitted to imagine that he can grow old; and thus every officer of the household stains his hair and beard, and uses all the means with which art or invention can supply him, in order that no intrusive symptom of age or decay may shock the nerves, and awaken the regrets of his lord and contemporary - the faded beauties of the Seraglio are removed from his sight, the past is seldom adverted to, and the future is considered as his sure and undoubted heritage.

Never did monarch lend himself to the delicious cheat more lovingly than Sultan Mahmoud; who, with all his energy of character, is the vietim (for in his case I can apply no other term) of the most consummate personal vanity. We are accustomed in England to think of George the Fourth as the ne plus ultra of exquisitism - the Prince of Petit-maitres - but 
what will honest John Bull say to a Turkish Emperor, an Imperial Mussulmaun, who paints white and red, and who considers himself sufficiently repaid for all the care and anxiety of a costly toilette, by the admiration and flattery of the ladies of the.Seraglio? And yet such is the case-the Immolator of the Janissaries, the reformer of a mighty empire, the sovereign of the gravest people upon earth, is a very "thing of shreds and patches" - a consumer of cosmetics - an idolater of gauds and toys - the Sacrificing High Priest at the altar of self-adornment!

On a recent occasion, having caused his hair (of which he is extremely vain) to be cut by the court coiffeur, he withdrew his fèz and inquired of his son-in-law, Halil Pasha, if he approved of the style in which it had been done. The Favorite, with a sincerity which did him honour, replied that the Imperial Head had been most basely shorn; and was forthwith desired to display the honours of his own cranium to his Sublime Highness; who immediately acquiesced in the superior skill of the artist who had operated upon the Pasha; and desired that, without a moment's delay, the happy mortal who had exhibited such distinguished taste in curling and cutting should be summoned to his presence.

ln live minutes, half a dozen of the palace officers were en route in search of the coiffeur, 
who was accidentally from home: and it was not until after a considerable delay that he was discovered, basin in hand, and razor in grasp, busily engaged in shaving the head of a gravelooking Armenian, who had already undergone half the operation. Despite the lathered skull of the customer, and the terrified deprecations of the artiste; the officers, who were utterly ig: norant of the Sultan's motive for summoning their prisoner, pounced upon him without mercy, and rather dragged than conducted him to the caïque that was waiting to convey him to the palace; whither he was followed by the silent and pitying wonder of the men, and the low. wailing of the women.

On his arrival, he was immediately led into the Imperial presence, where his trembling knees instinctively bent under him, as he wildly gasped out his innocence of any and every crime against His Sublime Highness; he wrung his hands, he implored a mercy for which he scarcely dared to hope, he writhed in his agony of spirit, expecting nothing less than the bowstring for some imputed delinquency, and he talked of his wife, and his young and helpless children so soon to be cast upon the world unless his life were spared; while the Sultan laid aside his fèz, and prepared his own head for a more simple operation.

“Peace, fool!" said His Highness at 
length, "did you not eut the hair of Halil Pasha?"

"I did, your Sublime Highness; and to the best of my poor skill," faltered out the pale and terrified artiste; "have mercy upon my want of knowledge!"

"Compose your nerves, and produce your scissors," returned the Sultan; "you shall have the distinguished honour of cutting mine, alsoto your task at once."

No sonner said than done: men of this craft have been gifted with ready wit and self-possession, from the days in which the red-robed ghost of the German barber shaved the adventurous student in the haunted castle; and ere long His Imperial Highness was cropped and curled to his sublime satisfaction ; and the hairdresser found himself appointed keeper of the head of the Turkish Empire-a " man of mark" -and returned to his home in triumph, not only quitte pour la peur, but with his wildest visions realized!

During the short period that the Sultan remained in the mosque, the scene around us was far from unamusing: the horses were paraded to and fro; the troops rested on their arms, and conversed freely with each other; the offieers, breaking through the spell that had lately bound them, resumed their stroll and their scrutiny; and many a glance was directed 
towards our little party, for which we were indebted to the curiosity of their Imperial Master. Then came a rush from the great entrance of the mosque; and, when a host of red-capped and turbaned Turks had issued forth, the ChèikIslam slowly descended the steps, and departed in the same state as he had come. The horses were led back into their ranks; the military shouldered their muskets; and once more the Seraskier Pasha with his train of attendants paced slowly along the line.

Those officers who were of sufficiently high grade to attract his attention made their graceful obeisance, first laying their right hand upon their lips, and then upon their foreheads, and bowing down nearly to the earth ; while the Pashas, who were not of a rank elevated enough to appear mounted before the Sultan, moved amid the throng, with their diamond orders and embroidered sword-belts glittering in the light. Among these was Namik Pasha, whom I had known in England, and who approached the carriage to greet me, while the Seraskier reined up his horse beneath the window of a house that overlooked the scene, and paid his compliments to Madame de Boutenieff, who sat surrounded by secretaries and attachés.

One by one, all the Pashas re-appeared, and, having saluted each other with a ceremonious etiquette that distinctly marked their respec- 
tive. ranks, they marshalled themselves round the gateway according to their precedence of power; and then it was that I particularly remarked the unpleasant effect of their ungloved hands, so utterly inconsistent, according to European ideas, with the magnificence of all the other details of their costume.

By a happy, though not altogether singular, coincidence, the husband of one of the princesses, and the intended husband of the other, are both the adopted sons of the old Seraskier; and as they took their places on either side of him, they naturally excited considerable attention.

Halil Pasha is a good-looking man, but clumsily and ungracefully made, with a grave expression of countenance; which, if report speak truly, the temper of his Imperial helpmate is not calculated to gladden.

Having mentioned the Princess Salihè, I may as well introduce in this place a little anecdote, for whose veracity my informant pledged himsclf. Her Imperial Highness, on one occasion, only a few months back, chanced to pass in her araba by 'a' coffee-kiosk, in : which a party of Ulemas, about thirty in number, were gravely smoking their chibouks... It chanced that no individual among them remarked the approach of the Imperial carriage; and they consequently all remained seated, as though the owner of the equipage nad not been the Cousin of the Sun 
and Moon, and herself one of the principal constellations. The rage of the Princess was unbounded; and she instantly despatched one of her kavashlir for an armed guard, to whom she gave orders to convey the whole party to the palace of the Seraskier, to receive the bastinado for the want of respect which they had displayed towards her sacred person. To hear was to obey ; and forthwith the thirty. Ulemas, members of the most powerful body of men now existing in the Empire, were marched off to the Seraskier; to whom, on their appearance in the court of the palace, it was immediately announced that a formidable group of Ulemas, attended by a number of soldiers, were approaching, as if to demand an audience of His Excellency.

The Seraskier, anxious as to the purport of their visit; ordered that they should instantly be admitted; and, suspicious of some popular discontent, resolved upon giving them a most courteous reception; when he was struck dumb by the intelligence that they were prisoners sent to receive the punishment of their crime! For a moment even the Seraskier was at fault; but, suddenly looking towards them with a smiling countenance, and affecting not to remark the lowering brows of the outraged professors "Her Imperial Highness has condescended to make merry, with me," he said gaily. "She threatened that I should pay dear for some un- 
palatable advice that I ventured to give her, and you are to be the medium of her vengeance. I comprehend the jest, and must abide by her good pleasure." Then, turning to his pursebearer, he desired him to count out one hundred piastres to each individual, which was accordingly done, and the discomfited Ulemas left the palace.

But the affair might have proved to be the very reverse of a jest in its consequences, and this the Pasha well knew when he ventured to set at nought the orders of the princess; and he accordingly lost no time in obtaining an audience of the Sultan, to whom he explained the whole circumstance. His Highness, after commenting gaily on the expedient of the Seraskier, and causing steps to be taken to ascertain that the aggrieved parties harboured no thoughts. or designs of revenge, sent a stern message to his Imperial daughter, in which he warned her not to attempt on any future occasion to bastinado his learned and faithful subjects, thirty at a time.

Said Pasha, the affianced bridegroom of the Princess Mihirmàh, is decidedly the handsomest man at court, as well as one of the youngest; he has fine eyes, a prominent and well-shaped nose, and a smile of peculiar sweetness.

A burst of martial music again warned us of the approach of the Sultan; and, as he moved 
along upon his proud steed, which tossed its party-coloured plumes and flashing jewels in the clear sunshine, he turned towards us another look and another smile--and, in a few minutes, nothing of the pageant remained with us save its memory ; if, indeed, I except the band, whose thrilling music, as they marched past, startled our horses, which began to rear and kick in so inconvenient a manner that we were glad to drive off; and, taking our way through "The Valley of the Sweet Waters," along the banks of the sparkling Barbyses, and past the Imperial Kiosks, that rise like fairy palaces from the soft turf of that lovely spot, we returned, amid the freshness and beauty of a quiet day in Spring, to our residence at Pera. 


\section{CHAPTER XII.}

The Military College - Achmet Pasha and Azmi Bey-Study of Azmi Bey-His grateful Memories of England and the English-The Establishment-The Lithographic Presses - Extemporaneous Poetry Halls of Study - Number of Students - Mathematical Hall - The Sultan's Gallery-The Mosque-The Mufti-The Turkish Creed The Imperial Closet - The Gallery of the Imperial Suite-The Retiring-Room-The Printing-Office-The Hospital-The Refectory -The Professor of Fcrtification - Negro Officers-Moral Condition of the College - Courtesy of the Oticers - Deficiencies of the Protessors - The Turks a Reading People - Object of the InstitutionReasons of its Failure - Smiling Enemies-Forlorn Hope-Russian Influence-Saduk Agha- $-\Lambda$ chmet Pasha-Azmi Rey $-A$ pology for my Prolixity.

The Military College, which, from its extent, and the lavish liberality of its arrangements, may well be termed a princely establishment, occupies the crest of a hill immediately above the Imperial palace of Dolma Batché, signifying the "Valley of Gourds"-and the tall minaret of its mosque shoots upwards into the blue heaven with the grace and lightness of a sky-winged arrow; while the gilded crescent in the centre of the dome reflects back the sparkling sunbeams as they flash upon its glittering surface.

As I had brought an introductory letter to Achmet Pasha, the governor, and had been per- 
sonally acquainted in London with Azmi Bey, the Military Commandant, and, in fact, Principal of the Institution, I experienced no difficulty whatever in obtaining permission to pay it a visit; and I accordingly proceeded thither, accompanied by my father and a couple of friends, who were, like myself, anxious to form a correct opinion of the establishment.

We were met at the great entrance by the young Bey himself, who welcomed us with the most sincere cordiality; and, offering me his arm with a ready politeness quite European, he conducted us to his private apartment, or, perhaps, I should rather call it, study. This very cheerful and comfortable room, situated at an angle of the building, and commanding two magnificent points of view, was thickly hung with English and French engravings, principally interiors of our metropolitan buildings, college-halls, theatres, and other places of public resort, highly coloured - a large stove gave forth an agreeable warmth-the window seats were strown with books and papers-a few maps were lying upon a side table - a curious collection of volumes was gathered together in a small bookcase-and the apartment had altogether a more furnished and snug look than any which I had yet seen inhabited by a Turk-there were flowers also in a glass vase; and a paperpresser on which a sleeping Cupid lay stretched 
listlessly among his fabled roses - the souvenir of an European friend.

We remained some time talking over past days, and I was sincerely pleased by the fond and grateful manner in which he spoke of England, and his English acquaintance. He reminded me of several little bygone incidents, inquired for particular individuals, and exhibited a warmth of feeling and interest in the past for which I was scarcely prepared. During the conversation, tea was handed to us in the Russian fashion by his dragoman, attended by two negro slaves, and after partaking of it we commenced our survey of the establishment.

The main building forms three sides of a square, and the centre of the fourth is occupied by an elegant kiosk-like edifice, containing the lithographic presses. Here we found an individual designing a very neatly-ornamented sheetalmanac, of which he had sketched the border with great delicacy. All the machinery is English, and appears to be in constant use. I have omitted to mention that, before we quitted the apartment of Azmi Bey, he presented to us several of the Professors, who entered to pay their respects. Among these, the most remarkable was Saduk Agha, a Prussian renegade, who speaks French, Italian, and Turkish fuently, and has a considerable knowledge of English. After conversing with him for some time on the 


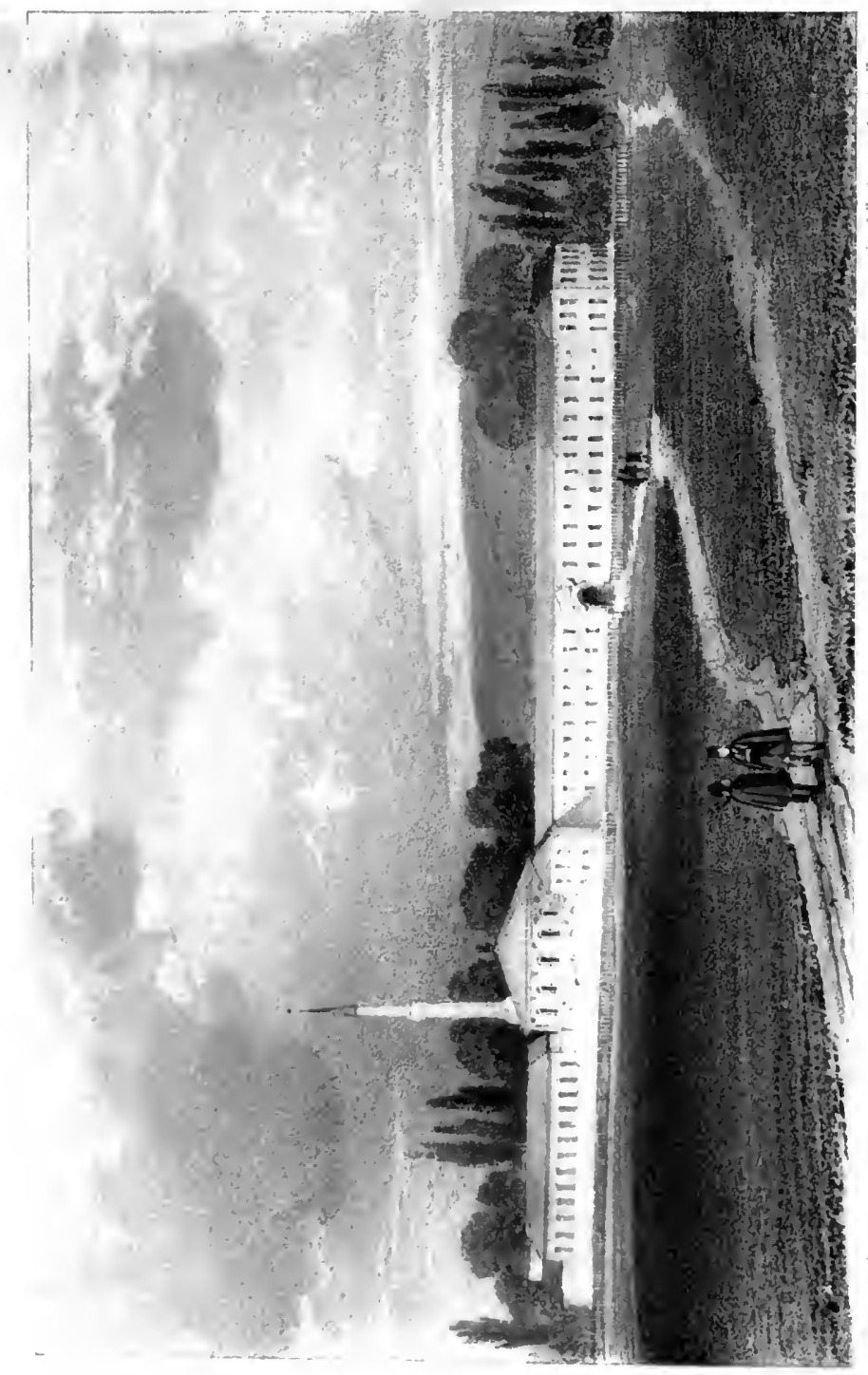



merits of lithography, and examining a number of drawings, principally military figures, that had been executed by the pupils of the establishment, and were many of them of considerable merit; he joined his entreaties to those of $\mathrm{Azmi}$ Bey that I would write a few lines as evidence of my visit, which they might put under the press. Finding that they were both determined to succeed, and not considering the point worthy of contention, I complied with the request, not a little amused at my first appearance in print in Turkey: and I much doubt whether any thing that I have hitherto written, am now writing, or may hereafter write, will ever be read and re-read with so much apparent gusto as the half dozen lines of doggrel verse which I improvised on a scrap of torn paper, sur la plante des pieds, surrounded by about a score of Turkish spectators.

From this point, we proceeded to the inner or garden court, of which one side is laid out in a parterre inclosure, the eentre being occupied by the mosque, and the extreme end terminated by the two great halls of study. We entered the first of these by a noble flight of stone steps, and found ourselves in an apartment of vast extent, admirably lighted, and arranged with the most perfect order and conveniency. 'Thickly set rows of high-backed benches of stained wood extended the whole depth of the hall, leaving a 
passage on either side just sufficiently wide for the ingress and egress of visitors; and the first ranges of seats were occupied by about one hundred and fifty of the junior pupils, who were busily employed in tracing upon their slates the elegant characters of their language, as sentence after sentence was slowly declaimed by the head boy of the class. 'This department of the institution is on the Lancastrian system.

There are at present only three hundred students on the establishment; a report having been promulgated by its enemies that an attempt would be made to interfere with their religious tenets; in consequence of which many parents declined sending their sons: the only answer of the Governors to this calumny has been to compel the attendance of the boys three times a day at the mosque; a tolerably convincing proof that they entertain no anti-Mohammedan partialities.

As the School is expressly intended as a nursery for the army, all the ambition of the students is made to bear upon that point: extraordinary application, or regularity of conduct, is recompensed by a step of military rank; and thus, should the intention of the authorities ever be borne out, a youth of talent and good conduct may hereafter quit the college as an officer, and thus commence his actual career of life, where many of his predecessors have terminated their's. 
Having traversed the Lancastrian class, we reached the mathematical hall, where a considerable number of young men were busily engaged in colouring ground-plans of the surrounding country: The lower end of this stately apartment forms a deep bay, round which rows of seats are arranged amphitheatrically, having in the midst of them a table whereon are placed globes, charts, and all the requisites for study. The other extremity of the hall is terminated by a raised gallery, intended for the use of the Sultan, above which hangs his portrait in oils, executed by an Armenian artist, harsh, and crude, and wiry, as though it had been the production of a Chinese eascl, and surmounted by a most elaborate drapery. Beneath the portrait is stretched a noble map of the Archipelago, the Sea of Marmora, and the Bosphorus. An electrifying machine, and a large map of America, an immense table, and the desks and seats of the students, made up the remainder of the furniture; and the. apartment itself was by far the finest that I had yet seen in the country.

The next point of curiosity was the mosque; and I was no less surprised than gratified at the readiness with which Azmi Bey acceded to our desire of visiting it. The outer apartment, or restibule, was covered with fine Indian matting, and before we traversed it the Bey requested my 
father to put off his boots, though he made no objection to my retaining my slippers. As we reached the door which opened into the body of the mosque, I perceived that we had arrived during the prayers. The High Priest sat with his arms folded above his ample robe; his dark brow surmounted by a turban of the sacred green, and his feet doubled under him, in a recess facing the entrance, chanting in a nasal and monotonous drawl; while a very slender congregation was scattered over the floor, squatted upon the rich carpets that covered it. But we no sooner male our appearance than the Mufti rose and quitted the mosque, followed by his little flock; and we were left in quiet possession of the elegant temple whence they had so hastily withdrawn.

The faith of the Musselmauns is that of love, not fear: to believe in One Gop, and to be charitable - and who shall deny that it is a comprehensive' creed? The mosque in which we stood was the very embodiment of such a worship - the sunshine streamed through its many windows upon the most delicate frescopainting, the brightest and richest of carpets, and the glittering lattices of the Imperial closet. The only dark object that met the eye was a curtain of olive-coloured cloth, surrounded by a bordering of flowers, delicately worked in tinted silks, which veiled the entrance of the marble 
steps leading to the pulpit-all beside was dazzlingly bright, and it was almost with regret that 1 returned into the vestibule, in order to ascend to the Sultan's gallery.

A small hall and a handsome flight of stairs, closely covered with English carpeting, conducted us to an elegant anti-room, from which four doors, veiled by draperies of dove-coloured cloth heavily fringed, opened into as many apartments, appropriated to the Sultan and his suite.

The Imperial closet is richly hung with goldcoloured draperies, that fling a sunset glow on the surrounding objects : a magnificent sofa occupies one side of the room, and the floor is covered with a Brussels carpet. Portions of the gilded lattice open and shut at pleasure; and the whole has so perfectly Oriental an effect, that you involuntarily think of Schenerazade and her fable-loving Sultan; and forget the sanctity of the place, while contemplating the luxury of its arrangement.

The gallery appropriated to the Imperial suite adjoins the closet, and beyond this is the retiring-room of the Sultan, wherein he performs his ablutions, previously to the commencement of the service. It is less gorgeous in its general effect than the closet, but commands a noble view of the Bosphorus, and the Sea of Marmora.

On leaving the mosque, we descended by a 
flight of stone steps into the vaults beneath it, to visit the printing-office, where all was activity: compositors were setting the types "devils" were guiding the rollers-lads were folding the printed sheets-and binders were stitching them into volumes. Every thing was clean, and orderly, and well conducted.

We next made a tour of the hospital; and, had not two of the beds been tenanted, I should have quitted the establishment, if not with a firm conviction, at least with a very strong suspicion, that it was intended merely for show, it was so delicately clean and so beautifully arranged.

At the heal of the stairs was the receivingroom of the surgeon; and beyond this, on either side of the gallery, were the laboratory and the surgery, their doors veiled with white muslin, and every article in its place; the dormitories, which are only two in number, each capable of containing about a score of patients, were carpeted along the centre; the beds were tastefully draperied with muslin: and a small table stood near each pillow; while along the cornice of the ceiling were suspended, at regular distances, small tablets, whereon were inscribed the names of the different diseases to be treated in the wald.

'The refectory was perfectly European in its aspect, surrounded by long narrow tables and 
benches, and well supplied with plates, spoons, forks, and soup-ladles. As we entered, Azmi Bey looked towards us confidently for applause. He had truly worked a goodly reform in Turkish habits, when he taught each boy to put his fork into his own plate, instead of plunging his fingers into the dish of the community! Nor did we fail to compliment him on the change.

By the time that we had completed our survey of the Establishment, our "tail" would have been no comtemptible rival to that of $\mathrm{Mr}$. $\mathrm{O}^{\prime} \mathrm{Con}$ nell - every Professor and Officer connected with the Institution having made his bow, and joined the party. And not the least conspicuous of the number was the Professor of Fortification, who, besides being a creole, had one of the most frightful and resolute squints I ever had the misfortune to meet with; and the Captain of the Guard, a very corpulent and consequential negro. Black officers and soldiers are, however, common in 'Turkey, where a man's colour is never construed into an objection to profit by his services, nor an excuse for leaving them unrewarded.

Having described in detail the external arrangements of the Military College of Turkey, it now remains for me to advert to its moral condition, and this is truly a melancholy task ; for, rich as I have shown it to be in all the outward attributes necessary to such an Establishment, it is utterly destitute of the more essential 
requisites for insuring the important end of ${ }^{\prime}$ its foundation.

Care and cost have been lavished upon it unsparingly: it is a favourite toy of the Sultan-a subject of ceaseless thought and interest to Achmet Pasha, to whose immediate control it has been entrusted-the one engrossing object of Azmi Bey's solicitude - the Great National Scholastic Establishment-the nursery for the Imperial Army. But, alas! despite all these advantages, it is like the Statue of Pygmalion ere it was warmed to life-a body without a soulmatter without mind-a splendid machine, without a competent and practised hand to call forth its powers, and to work out its effects!

To the courtesy of the several individuals immediately connected with the Institution, I have already borne testimony; nor does a doubt exist in my own mind of their sincere zeal for its welfare and prosperity. But, unhappily, the best intentions, and the most earnest enthusiasm, must fail to compensate the painful deficiency of that talent and experience necessary to its success. Could sentiment be deepened into science, and inclination be wrought into ability, the Military College would take high ground; for the students are eager in the pursuit of knowledge, but, where the means are limited, the effects must be comparatively inconsequent: and it is a melancholy truth that 
the untiring application, the admirable docility, and the promising talents of the pupils, can only conduct then to a certain point, beyond which their best efforts will not enable them to progress unassisted. This is more particularly the fact as regards the youth of Turkey, from the circumstance of their being by nature imitative rather than inventive; and, moreover, not possessing those opportunities of observation and individual research which lead the students of Europe to rely in no trifling degree upon their own mental resources.

In our western world the wings of Genius are never clipped-the sunny path of Talent is never overshadowed-the calm brow of Science is never clouded-by a deficiency in the means of further improvement, encouragement, and support. But Education, as we comprehend the term, is yet in its first infancy in Turkey; and should the same evil influence which is now blighting with its Upas breath the Ottoman atmosphere be long suffered to exhale its poisonous properties, it is certain to annihilate all power of improvement.

Perhaps, with the single exception of Great Britain, there exists not in the world a more reading nation than Turkey. I have no doubt that this assertion will startle many individuals in Europe, who have been accustomed, and, indeed, led to believe, that the natives of the East are, as a people, plunged in the profoundest 
ignorance. It is, nevertheless, a fact that nearly every man throughout the Empire can rearl and write, and that there are at this moment upwards of eight thousand children scattered through the different schools of the capital. But the studies of the Osmanlis of both sexes have, with some few exceptions, hitherto been confined to the Koran, and to works of an inconsequent and useless description; the mere plaything of an idle hour, incapable of inspiring one novel idea, or of leaving upon the mind impressions calculated to exalt or to enlighten it.

The object of such an Institution as a Public School was undoubtedly to widen the mental views, and to enlarge the tastes of the youth of 'Turkey. But, in order to effect this very desirable end, it was requisite that the soundest judgment should be exercised in the selection of the individuals to whom were committed its different departments of literature and science, and this was unfortunately far from being the case; the internal economy of the Establishment having been entrusted to persons so decidedly incompetent that, with every desire to do their duty, they have erred, from their utter ignorance of the extent of the task which they have undertaken, or which has been forced upon them.

As far as the different Professors are capable of so doing, they have directed the studies and 
formed the tastes of the students ; but the young and ardent mind, thirsting after knowledge, and earnest in its acquirement, demands assistance as progressive as its own advancement. 'The fresh and buoyant spirit requires external aid, at once able and judicious, to support its vigour, and to strengthen its yet unpractised wing. And where these fail, where the shadow is alone furnished, while the substance is wanting, what can be expected from the comparatively unassisted efforts of young and unformed intellects, that have not simply to struggle onward towards a goal to be attained only by their best energies; but also to contend against, and to cast from them, a crowd of early prejudices and associations-while they are destitute of the assistance of more experienced and mature talents, upon which to fall back, when they have themselves just acquired sufficient knowledge to feel their own deficiencies?

Let it not be believed for an instant that the Turks, had they been left to the free exercise of their own good sense and reflection, are so obtuse as not to have made the discovery that the progress of the pupils was necessarily retarded by the inexperience and incompetency of the preceptors. He who judges thus hastily will wrong them. Already had the suspicion sprung up in their minds - already did those on whom the authority for so doing more particularly 
devolved suggest the expediency of procuring, from Europe, men of talent, science, and judgment, capable of sustaining the credit of the Establishment. But the project was crushed in the bud; negatived on its first suggestion; set aside by a single sentence; that sentence which has become all-powerful in Constantinople and thus the ruin of the Institution is already sealed by the incapacity of its professors, the prejudices of its enemies, and the lavish and deceitful encomiums of its false friends.

Achmet Pasha has been told that never did establishment prosper like the Military College of Constantinople. A foreign minister has declared it perfect; and obsequious secretaries and attachés have raised their hands and eyes in almost religious wonder. Compliments have been lavished on the meagre talents of the masters, and smiles have veiled their deficiencies. And thus, flattered into a belief of their own sufficiency on the one hand, and misled by misstatements on the other, the influential individuals connected with the unhappy College have abandoned it to the ruin which must ultimately, and at no distant period, overtake it; from the hopeless incapacity of a set of men, who, familiar with the name of every science under Heaven, are most of them profoundly ignorant of all save the first rudiments of each; and who are, consequently, ill calculated to work that great moral 
change so ardently desired by all the true friends of Turkey.

I put forth this assertion boldly, because I have convinced myself of its justice; and if after having stated the eagerness with which the students seek to acquire information, the care and cost that have been lavished on the College itself, and the zeal and untiring watchfulness of those to whose charge it has been intrusted - I am asked the simple question of wherefore this great National Institution is crippled in so senseless and ruinous a manner by the appointment of inefficient individuals to its most important and responsible posts, the answer is ready-It is the will of Russia!

The growth of knowledge is the destruction of tyranny and oppression: it is the moral axe struck to the core of the wide-spreading Banian of usurpation and encroachment-it is the light of mind, dispelling the darkness of prejudice and falsehood.

Were Turkey once roused to a perfect estimate of her own moral power, she must inevitably cast off the web that has been slowly and craftily woven about her; and which, should no friendly hand disentangle its intricate threads ere it be yet too late, must ultimately fetter her strength beyond all power of resuscitation. To do this she must take an enlarged and correct view of her position-she must be able to appre-

VOL. I. 
ciate her just value among the nations-she must be capable of combating sophistry with caution, and craft with calculative wisdom. This power she can only acquire by placing herself upon a mental equality with more civilized Europe ; by training up her youth to habits of reflection and scientific research; by awakening within their breasts the generous emulation of excellence; and by opening before them paths of honour and advancement, no longer to be trodden by the weak foot of chance, but sacred to superior merit and superior genius.

All this must Turkey accomplish ere she can once again be great and free. And it is to prevent this that the subtle policy of her archenemy, Russia, strains every nerve, and exerts every energy - the blandishments of a flattery, to which she is constitutionally too susceptible for her real welfare - the threats of a strength beneath which she is unfortunately already bowed almost to the dust - for should some generous spark of honour be aroused to resistance, there is the unanswerable declarationL'Empereur le veut! beyond which there is no appeal.

'Thus Russia looked upon the College with a jealous eye-it might, if suffered to -progress towards perfection unchecked, ultimately become a great moral engine in the hands of the Turkish government: and this was, of course, not to be permitted. The Russian Legation con- 
sequently took an overwhelming and most generous interest in all the details of the establishment; laughed to scorn the necessity of European science and European assistance, where native talent was so rife-employed her creatures in writing complimentary and fulsome panegyrics on the Institution, which were lithographed at the school, and translated for the Sultan; and, in short, administered such copious draughts of flattery to all connected with the establishment, that their soporific effects are painfully apparent in the quiet, self-gratulatory, smiling satisfaction of those, who. while they believe that they are nursing the new-born Institution into vigour, are actually closing their encircling arms so tightly about its throat that they are strangling it in its first weakness.

The School has but one hope-and that is unhappily faint and afar off. There are now between thirty and forty promising young men studying in Europe, who may perchance one day be enabled to effect its resuscitation. But years must elapse ere the most gifted pupils are eligible to become preceptors: and before those years are past, what may be the fate of Turkey? England must resolve the question.

At present it is certain that the Military College is indirectly under Russian control and patronage; all the professors having been selected openly or covertly by themselves. And thus, 
one individual, for the limited remuneration of about $£ 200$ a year, not having the fear of ridicule before his eyes, gravely undertakes to impart to his pupils the knowledge of some half dozen sciences, among which geography and astronomy are far from being the most profound or conspicuous.

Saduk Agha, of whom I have already spoken, is a man of distinguished abilities, who, had he been suffered to do so, might have materially assisted the studies of the pupils ; but this point would have been too mighty for Russian policy to concede; and, as it was not judged prudent to exclude him altogether, and thus draw down remarks which might have proved inconvenient, his services were secured at a salary of $£ 150$ a year, to teach the Prussian game entitled Le Jeu de Guerre, which is a species of dissected military map, put together precisely like the puzzles used by children in England.

Achmet Pasha, (to whom, as I have already remarked, the superintendence of the Institution has been immediately confided), however much he may desire its prosperity, has scarcely time, talent, or opportunity, (as I think it will be conceded when I have enumerated his multitudinous avocations) to give to it the care and attention which it requires from its Principal ; or to bestow upon it that watchful surveillance so necessary to the prosperity of an Establishment 
for youth. He is Grand Chamberlain-Generalissimo of the Imperial Guard-Governor of the Military College-Director of the Roads-Grand Master of the Artillery-Head of the PoliceInspector of Naval Architecture - pro tempore Lord of the Admiralty, and Governor of Natolia-in short, he either is, or requires to be, an universal genius.

Azmi Bey, the Military Commandant, with a zeal which retains him a willing prisoner almost constantly within the walls of the college, and an enthusiasm that neither difficulties nor disappointments have yet quenched, is, nevertheless, too young and too inexperienced to be equal to meet efficiently the weighty responsibility that has been thrust upon him; and for which he is indebted to a quickness of observation, an ardent desire of improvement, and a facility of imitation, called forth and developed by his brief residence in Europe. All that he was competent to effect, he has already accomplished; for he has reduced to order the chaos of conflicting prejudices and associations, and habits, which met him, Hydra-headed, on the very threshold of his task. From his limited experience of European feclings and manners, he has also profited sufficiently to enable him to adopt much that was worthy of imitation; while, on the other hand, he has judiciously rejected much of which the utility and desirable- 
ness were at best problematical. The easy, I may almost say, affectionate manner of all around him convince you at once that he is gentle in his rule; while the earnestness with which he interests himself in the most minute details connected with the Establishment is an equal proof of his unfeigned desire for its success. But the brevity of his European sojourn, and the confusion of ideas, and hurry of mind, consequent on a residence in London during the height of the season - the rapidity with which he was whirled from military and naval colleges to railroads and manufactories, from museums and libraries to public gardens and theatres-could scarcely, even with the most ceaseless efforts on his own part, have afforded opportunities for study, or time for reflection and research, calculated to render him the efficient mainspring of so complicated and delicate a picce of machinery as a great National Academy.

I fear that I have been prolix on the subject of this interesting Establishment, which might have become a moral sceptre in the hand of a future Sultan, and which is now "a vain shadow" and "a whitc-washed sepulchre;" but it is impossible not to feel deeply the cruel wrong committed by the false sophisms of a smiling enemy, towards a confiding and unsuspicious people; yet was my sympathy unmingled with surprise. Did not Russia refuse to allow the Porte to 
ratify the engagements entered into by Reschid Bey with the European officers whom he had selected for the service of the Sultan? And was it probable that she would permit a nearer and a more certain danger without an effort to annihilate it?

One more question, and I have done. Will the traveller in Turkey, fifty years hence, have any thing to tell of the Military College of Constantinople? Alas! I doubt it. 


\section{CHAPTER XIII.}

Invitation from Mustapha Pasha of Scodra - The Caïque, and the Caïquejhes - How to Travel in a Caïque - Hasty Glances-SelfGratulation - Scutari - Imperial Sıperstition - The Seraglio Point -Dolma Batehè - Beshiktash — The Turning Dervisbes-Beglièrhey-The Kiosks - A Dilemma-A Ruined Palace-An Introduction - A Turkish Beauty - A Discovery- $A$ New AcquaintanceThe Buyuk Hanoum - Fatiguing Walk - Palace of Mustaplıa Pasha-The Harem-Turkish Dyes-Ceremonies of Reception Turkish Establislıment-The Buyuk Hanoum-Turkish Chaplets'The Imperial Firman-Pearls, Rubies, and Emeralds-The Favourite Odalique-Heyminè Hanoum-A Conversation on Polities-Scodra Pasha-Singular Coincidence-Convenience of the Turkish Kitchen Luxury of the Table-Cuquetry of the Chibouk-Turkish Mode of Lighting the Apartments - Gentleness towards the Slaves-Interesting Reminiscences - Domestic Details - Dilaram Hanoum - A Paragraph on Pearls - A Turkish Mirror-A Summons-Scodra Pasha-Motives for Revolt-The Imperial Envoy-Submission Ready Wit of the Pasha's Son - The Reception Room-Personal Appearance of the Scodra Pasha-Inconvenient Courtesy-Conversation on England - Philosophy-Pleasant Dreams-The PlagueSmitten.

Accompanied by a Greek lady of my acquaintance, I embarked one fine morning on board our caïque, to pay a visit to the wife and daughter of Mustapha Pasha of Scodra. As his palace was situated in a distant quarter of the city, and we were anxious to avoid the necessity of rattling over the rude and broken pavement of the streets in an araba, we resolved to stretch 
out beyond the Seraglio Point; and, following the walls that are now crumbling into ruin along the coast, disembark at Yani-capu, or the New Gate pier.

Our sturdy rowers accordingly bent to their oars, and the arrowy caïque shot across the port, and out into the wider sea beyond, like a wild bird. The boatmen were clad in their summer garb, for the sunshine lay bright upon the water, and scarcely a breath of air nurmured among the dark branches of the cypress groves. They wore shirts of silk gauze, of about the thickness of mull-muslin, with large hanging sleeves, and bordered round the breast with a narrow scallopping of needlework; their ample trowsers were of white cotton, and their shaven heads were only partially covered by small skull - caps of red cloth, with pendent tassels of purple silk; their feet were bare.

My companion and myself occupied cushions spread along the bottom of the boat: the most comfortable, as well as the safest way to travel in a caïque, which, from its peculiar formation, is liable to be overset by the slightest imprudence ; while our Greek servant, with his legs folded under him, was seated on the raised stern of the boat, immediately behind us.

What pretty peeps we had of the Seraglio gardens, as we shot along; through the many latticed openings contrived for the gratification 
of the fair prisoners. What magnificent glimpses of domes and minarets, of bursting foliage, of marble fountains, and of gilded kiosks! But, alas! how vain must have been all the luxurious inventions of the most luxurious of Sultans, to insure happiness to the tenants of this painted prison! I looked around me on the sea-birds that were sporting upon the wave - above me, to the fleecy clouds that were sailing over the blue ether-far into the distance where a shoal of dolphins were gamboling almost above the water ; and, as I felt the motion of the swift caïque, while it was gently heaved up and down by the current of the sea of Marmora, and saw how rapidly we sped along, I breathed a silent thanksgiving that $I$ too was free! Free to come and to go-to love or to reject-to gaze in turn upon every bright and beautiful scene of nature, untrammelled, and unquestioned-that no Sultan could frown me into submission-no Kislar Agha frighten me into hypocrisy - in short, that I was not born a subject of his Sublime Highness, Mahmoud the Powerful.

On our left, rose the lordly mountain of Bulgurlhu Dagi, above Scutari, whose shores were fringed with country-houses, and hanging gardens ; gradually deepening into a sterner character as they receded from the Bosphorus, and lifting to the sky the palace-like barrack, and the elegant Persian kiosk of the Sultan. The 
present. Sovereign has a superstition derived from an astrologer whom he consulted in his youth, that, while he is constructing Imperial residences, he is sure to be fortunate in his other undertakings; and hence he is continually adding to the almost countless numbers of palaces and kiosks, that occupy the loveliest spots throughout the vicinity of the capital.

The most extensive and ancient of these is that which is situated at the entrance of the harbour, and gives its name to the "Seraglio Point," the walls of the Imperial Serai running, as I have already mentioned, far along the coast. On the opposite shore is the small but elegant palace of Scutari, with its bowery terraces, which are overlooked by the Sultan's principal residence of Dolma Batchè ; and you may shoot an arrow from the many-coloured and irregularly constructed palace of Dolma Batchè to the vast edifice now building on the same border of the Bosphorus, with infinitely less taste and more architectural pretension - although, with true Eastern inconsistency, the whole of the stupendous palace above Beshiktash, save the foundation, is of wood, surrounded by a colonnade, supported on stately columns of white marble.

This palace, of which the expence is estimated at a million sterling, has been already a considerable time in progress; and is erected on a 
locality that was partly occupied by a beautiful kiosk of Sultan Selim, and partly by a Tekiè and Chapel of Turning Dervishes.

These latter, with a tenacity altogether incompatible with our European ideas of a despotic government, resolutely refused to quit their convent, when the plan of the new palace which rendered their ejection indispensable was explained to them. They had come to a resolution not to move-their mausoleum contained the holy ashes of a saint, and, in short, they were determined to measure their strength with the Sultan. Accordingly, raising the cry of sacrilege, they continued snugly within their convent walls, which were soon overtopped by the Imperial pile that rose gradually on either side of them.

But Sultan Mahmoud was born a century too late to be thus baffled-the work went on; and he bore the opposition to his will with most exemplary patience so long as it did not retard the operations of his architects. But, when the moment at length arrived which rendered expedient the removal of the fraternity, he claimed from the Chèik Islam, or High Priest, his permission to expel them ; and, having failed in procuring it, quietly mounted his horse, and rode up to the convent gate. The Chief Dervish met him on the threshold, and the dialogue was brief:"Your Tekiè occupies the ground necessary 
to the completion of my palace:- you must vacate it."

" We guard the sepulchre of a saint, may it please your Sublime Highness."

"My pleasure is your immediate removal-I have provided a place of reception for your community."

"We are not strong enough to contend against your Imperial will. We obey." And the fraternity were put in possession of an extensive edifice, lately occupied by the Court Jester!

By a strange chance, this house was situated immediately under the holy tomb which had afforded to the Dervishes their principal pretext for disobedience to the Imperial mandate; and the Sultan adroitly availed himself of the fact to impress upon them the eligibility of the situation, pointing out, with a solemnity worthy of the occasion, that it was more decent for them to be domesticated on the very spot consecrated by the remains of the illustrious deceased, than at the distance of a furlong, as had hitherto been the case. The observation was a happy one, and the remark unanswerable; and the fraternity were fain to affect aceordance with the sentiment, however inconvenient its effects.

Immediately opposite, seated upon the Asian shore, like a regal beauty contemplating her gorgeousness in the clear mirror of the Bosphorus, rises the summer palace of Beglièrbey--with 
its walls of pale gold and dead white; the prettiest and most fanciful of all the Imperial residences, and rendered doubly agreeable by its spacious gardens and overhanging groves.

But the kiosks! Who shall number the kiosks! those gilt-latticed, many-formed, and graceful toys, which seem as though they had been rained from the sky during an hour of sunshine - see them on the heights of the Asian shore-seek them in the depths of the "Valley of Sweet Waters"- count them as they rise at short distances along the walls of the Seraï-pause a moment to admire their fairy-like beauty as you gallop through some lovely glen, so wild and solitary that you almost fancied yourself to have been the first who has ever explored its recesses-any where, every where, you come upon them; and they are so neatly kept, so brightly gilt, and so gaily painted, that they look like gigantic flowers scattered over the landscape.

But back, my truant fancy, to the sea of Marmora, and the shores of Scutari; where the light caïque is bounding over the heaving waters, and Mount Olympus, with its crown of snow, is summoning you to memories of the days when, if Gods indeed were not, men lent them life! Back to the hoary walls of Byzantium-to the lingering relies of the Ancient Romans-to the City of the True Believers!

We passed the little bay of Cum-capu, or Sand- 
port, and our caïque shortly afterwards shot into the creek of Yani-capu; but we had not left the boat five minutes when we became suspicious that the servant was not altogether so familiar with the road leading to the palace of the Pasha as he had professed to be. Nor were our suspicions erroneous; for, after leading us up one street and down another; along the foot of the Aqueduct of Justinian; and amid the blackened remains of the last great fire, he fairly confessed that he had lost his way.

In this dilemma, we took a guide, who assured us that he was as familiar with the palace of the Scodra Pasha as with his own house, and so he proved to be; though the trifling inconvenience that ensued convinced us that we were as far from our object as ever. After threading a vast number of narrow streets, each more filthy than the last, we at length reached one which, built on a steep acclivity, boasted a somewhat more comfortable and cleanly appearance ; the houses were larger and better kept, and the shops less frequent and more respectable. Our guide stopped before a pair of great gates about half way up the hill, and, seizing the knocker, gave very audible evidence of our wish for admittance; after which he pocketed his piastres, and withdrew.

On the opening of the gate, we found ourselves in a small covered court, choked with 
rubbish. A house, literally " tottering to its fall." and propped on the garden side with heavy pieces of timber, presented itself as the palace of the Pasha; and the door of the harem, which one rude blow would have shivered to atoms, was immediately before us.

We looked at each other in wonder; but, as the servant who had given us admittance assured us that we had made no mistake, which we were not only inclined, but really anxious to believe that we had done, we desired to be conducted to the Buyuk Hanoum. A loud blow on the door of the harem, most portentously echoed by the void beyond, was instantly answered by the appearance of a tall, bony, grinning negress ; who, having bade us welcome, invited us to follow her to her mistress.

The stairs by which we ascended to the harem creaked and quivered beneath our weight; the window that lighted them was uncurtained, and its missing panes were replaced by rags and paper-there was no matting upon the floor of the empty, chilly, comfortless hall into which the apartments opened-and the whole appearance of the place was so desolate and wretched, that I shivered as I remembered that I had engaged myself to pass the night there.

Having traversed the hall, the slave lifted the heavy curtain veiling the door of one of the inner apartments; and, having obeyed her bidding, 
we found ourselves in a small, snug, well-heated room, closely carpeted and curtained; and at the instant of our entrance a beautiful girl rose from the sofa where she had been seated, and welcomed us with a smile and a blush that made us forget at once " the ruin of her house." There was one circumstance connected with the greeting, however, that struck us as very singular; she made no allusion to our having been expected : but there was, on the contrary, a sort of wonder and curiosity in her manner, which, with intuitive good-breeding, she did not express.

We were both still haunted by the idea that there must be some mistake; and this impression was heightened by the timid and constrained bearing of the young beauty, who, after having clapped her hands, and desired the two or three slaves who hastily obeyed the summons to prepare sweetmeats and coffec, suddenly sank into silence, as though waiting to learn the purport of our visit. My companion, acting upon the presumption that some mistake must exist, although she was unable to comprehend its nature, once more inquired if she were correct in supposing that we were in the palace of the Scodra Pasha.

Again she was answered affirmatively.

"And you are then the beautiful daughter of the Pasha, of whom I have heard so much ?" 
"I am the wife of his son,"-was the reply, which, concise as it was, brought a brighter blush to the cheek of the speaker.

And she was beautiful, according to the strict rule of Turkish loveliness; with rich red lips, large dark sleepy eyes, and a throat as white and dazzling as the inner leaf of the water-lily.

"You are young to be a wife; have you been long married ?"

"Exactly twelve months-I am thirteen; my husband is a year older."

" Did you expect us earlier?"

“Expect you !" echoed the fair Turk, opening her deep eyes in wonder: "Mashallah! how could I expect that two Frank ladies would come to visit me?"

This was inexplicable!

"I trust that the Pasha has quite recovered his late indisposition," pursued my companion after a moment's silence.

"I did not know that he was unwell; we have not heard from him lately."

"Heard from him ?" echoed Madame - in her turn; " my husband had a long conversation with him yesterday."

Again the beauty dilated her large eyes in wonder. "Impossible! He is in Albania." Here was the solution of the enigma. We were bound on a visit to Mustapha Pasha, the rebel -and we were under the roof of Omer Pasha, his present successor! 
After a hearty laugh on all sides, we were quite at our ease; the young beauty handed scented conserves and coffee to us with her own pretty, plump, henna-tipped fingers; and informed us that her mother-in-law, the Buyuk Hanoum, and herself, were occupying a house lent to them by a friend, for the few weeks which they found it expedient to pass in Constantinople, while making their arrangements for Albania, where they were shortly to join the Pasha.

After passing half an hour in chatting on various subjects, we rose to take our leave, and to profit by the polite offer of our new acquaintance to send a servant to point out to us the palace of Mustapha Pasha. As we were making our parting compliments, a slave came in to request that we would pay a visit to the Buyuk Hanoum in her apartment, whither she had just returned from the bath.

We immediately assented, and were conducted to a spacious room at the other extremity of the hall, where we found the lady seated under the tandour, and almost in darkness; the win. dows of the room being on the old Turkish principle-that is, perforated in a double tierthe lower ones so closely latticed that they admitted scarcely any light, and barely permitted those within to see into the street; and the upper ones, small and half circular, dull with rust, 
situated close to the ceiling, and, in several instances, where time or accident had displaced the glass, repaired roughly with thin planks nailed across. The atmosphere of the apartment was close and oppressive, perfume having been flung into the mangal as we entered, which was rising in a dense vapour ; and every creek and crevice in the room (and they were not few) being stopped with pink paper.

The Buyuk Hanoum received us with much courtesy, and apologized for not having welcomed us herself on our first arrival in her own apartment, owing to her having been at the moment in the bath; and she appeared much amused at the mistake, (of which her slaves had already informed her) that had brought us under her roof. She had formerly been a fine woman, but was no longer young, and had consequently lost all the charming fraicheur (I use the French word, for it is perfectly untranslateable) which is the great beauty of Oriental females. In the course of conversation, we discovered that she was sister to one of the wives of Achmet Pasha; and had herself been to pay a visit to the harem of Mustapha Pasha the previous day.

As our engagement still remained to be fulfilled, we did not long linger in the apartment of the Buyuk Hanuum; but, taking leave of herself and her pretty little daughter-in-law, who 
had, during our visit, remained standing at the end of the room, with her hands folded meekly before her, while we shared the sofa of the hostess : we placed ourselves under the guidance of a bearded and turbaned Moslem, who was awaiting us in the court-yard, and once more sallied forth.

What a walk we had! Up and down, and in and out, until I began to think that the tales of Eastern enchantment that I had read in my girlhood were now realized for my individual inconvenience, and that the palace was receding as rapidly as we advanced. I was not, however, suffered to persist in this idle fancy, for we really did arrive at last. although some hours later than we should have done, before the great gates of an extensive edifice, which I an bound to admit had, externally, more the appearance of a barrack than a palace. Half a dozen servants, several of them negroes, were lounging in listless idleness at the entrarce, which our arrival instantly changed into ready and officious bustle.

We were ushered across an extensive courtyard to one of the wings of the palace, a vast, irregular, pile of building; and a single stroke upon the door of the harem was immediately answered from within: a group of smiling female slaves received us in an inner court, wherein stood the araba of the Buyuk Hanoum, 
and a very handsome marble fountain, at which a pretty girl of about eighteen was performing her ablutions. A couple of the negroes accompanied us up stairs, and, leading us across a very handsome saloon, whose recesses were filled with cushions, and whose open gallery commanded the court beneath, showed us into a smaller apartment, and seated us on a sofa, whereon lay a mandolin and a tambourine, probably flung there by some fair musicians whom our approach had startled from their pastime.

Here we were shortly joined by a very old woman, who came to pay her compliments to us ; and who, from her manner, was evidently a confidential person in the harem. She had been extremely beautiful, and was still a fine ruin; the outline of her features being delicate and regular; while her hair, of a bright chesnut colour, unmixed with a taint of gray, gave her a softness of expression perfectly singular. This latter circumstance only served to convince me of the great superiority of the dyes in use among the Turkish women, to those common in Europe; a fact which $I$ had already occasion to notice: whatever may be the age of a Turkish female, she is seldom disfigured by gray hair, but, on the contrary, her tresses are as pure in colour, and as smooth and glossy, as those of the youngest girl in her family.

A female slave shortly afterwards appeared to 
conduct us to the apartment of the Buyuk Hanoum, which, when we entered, was half filled with attendants, some standing in a semi-circle round the mangal, and others squatted on the carpet at the extremity of the room.

As this was the first harem that I had visited, where the establishment was on the true Turkish footing-or, to speak more plainly, where there were more candidates than one for the affections of the master of the house, although there was, in point of fact, actually but one wife-I paid particular attention to those delicate shades of etiquette and gradations of ceremony that I had been prepared to notice in these "princely families."

The Buyuk Hanoum occupied the upper end of the sofa, against which the tandour was placed; she was a plain woman, with a cold and somewhat stern expression of countenance: and there was more haughtiness in the bend and the smile wherewith she welcomed us, than I had yet seen exhibited by a Turkish female; when we entered, she was amusing herself, as is common with both sexes in this country, (as well Turks as Armenians) in passing rapidly through her fingers the beads of a chaplet, that rested on the gold-embroidered covering of the tandour.

I must be permitted a momentary digression on the subject of these chaplets, which are as 
popular, or very nearly so, as the chibouk. They resemble, somewhat, the rosary of the Roman Catholics, save that instead of being terminated by a crucifix and a knot of relics, they are merely beads strung upon a silk cord, divided at intervals by some of a larger size, and secured, at the junction of the cord, by a carved acorn, or an ornament of a like description. They are commonly made of a wood, which, becoming heated by the action of the hand,emits a delicious perfume; but their material depends upon the taste and means of the owner; the poorer classes carrying chaplets of berries, common beads, and other cheap substitutes, for this somewhat costly indulgence.

The more independent the circumstances of a Turk, and consequently the less use he is called upon to make of his hands, the more constantly are they employed in toying with his chaplet his fingers are busy with it as he walks along the street-you hear the light click, click, click, of the fast-falling beads, as he is squatted on his sofa - nay, so fond is he of this dull enjoyment, that, only a short period after my arrival at Constantinople, a Firman was issued by the Sultan, forbidding the use of the chaplet in the mosques, the noise of so many collected together, and all at work at the same time, disturbing the Mufti.

It is composed of ninety nine beads, without 
including that which connects the ends of the cord. With each of the former, an attribute of God is recited thus; Great-Glorious-Excellent - Omnipotent - \&c. \&c. The final bead terminates the ejaculatory prayer, and bears the name of the Deity himself.

The chaplet of the Buyuk Hanoum was of fine pearls, beautifully matched, and each the size of a pea, the divisions being formed by emeralds similarly shaped and sized, and the whole string secured by one pear-shaped emerald the size of a hazel-nut.

At the angle of the sofa sat the favourite Odalique of the Pasha, a short, slight, unattractive woman of about thirty years of age ; with common, and rather coarse features, but with a shrewd and keen expression that almost made them interesting. Close beside her was seated a third lady, who, although certainly not pretty, was nevertheless tall, graceful, and delicate, with full, fine eyes, and an exquisite complexion; when we entered, she was employed in fondling a sweet little child of between one and two years old. A pile of cushions, carefully and comfortably arranged, were prepared immediately opposite to the seat of the Buyuk Hanoum, for her fair daughter, but the lovely Heyminè had not yet left the bath.

At the invitation of the Buyuk Hanoum, we placed ourselves beside her, and partook of 
sweetmeats and coffee, amid the polite greetings of the whole party; and the refreshments had scarcely disappeared, when the fair bather entered the apartment.

How shall I describe the beautiful Heyminè Hanoum? How paint the soft, sweet, sleepy loveliness of the Pasha's daughter? She was just sixteen, at the age when Oriental beauty is at its height, and Oriental gracefulness unsurpassed by any gracefulness on earth. Her slight, willow-like, figure- her dark deep eyes, long and lustrous, with lashes edging like silken fringes their snowy and vein-traced lids - her luxuriant hair, black as the wing of the raven-her white and dazzling teeth-and the sweet but firm expression of her beautifully formed mouth

I had seen many lovely women in Turkey, but never one so purely, so perfectly lovely, as Heyminè Hanoum ; and I am not quite sure that I did not admire her the more for the deep shade of melancholy that cast a sort of twilight over her beauty, and softened, without diminishing, its effect.

She had been born in Albania; it was the land of her love; the Buyuk Hanoum, her mother, was descended from one of the most powerful and princely families of the country; and she had been used to see her looked upon with the reverence due to her birth and rank; she re- 
membered that the Pasha, her father, had dared, in his pride of place, to measure strength with the Sultan, his master, and to defy his power - he had failed, but the haughty effort had been made; and the fair Heymine looked back with sadness and regret to the days of past splendour and warrior strife amid which she had grown to womanhood. She clung to her mother with the loving gentleness that spoke in her deep eyes: but she worshipped her father, as something more than mortal ; and her fair cheek flushed crimson, and her proud lip dilated into smiles, as she spoke of him. And how she had garnered up within her heart those sweet, sad, memories which mock the brightness of the present! How she dwelt upon the country she had loved and lost, and amid whose mountains she had breathed the breath of freedom! I never saw the enthusiasm of the spirit more legibly written upon the brow of any human being than on her's. It redeemed the apathy of a score of Eastern women!

The Buyuk Hanoum was as far from being reconciled to the change of country and position as her daughter; but her sadness was more subdued by resignation - she had reached the age when reverses are less keenly felt - a calm sorrow sat upon her brow, and breathed in her low, tremulous, tone; but the blood which leaped to the brow of the daughter in warmer 
gushes as she spoke of the past only curdled more chillingly about the heart of the mother when the same visions arose in vain mockery before her, to remind her of what had once been, and could never be again!

Scodra Pasha had earned for himself a place on the page of history, but he had paid a high and a painful price for the privilege. He had tasted for a brief space the intoxicating draught of power, but the bowl had been dashed from his lips. He had defied the yoke beneath which he had been ultimately bowed, and the iron that has been resisted is ever that which eats deepest into the soul.

It must be a severe trial to sink from a leader to a vassal; even when it is from a rebel chief to the dependent Pasha of a Sultan. Mustapha Pasha had been almost a sovereign in Albania, a brave soldier, and a powerful prince; and, when he accepted the conditions of his Imperial Master, and bought his life at the price of his country and his fortune, the struggle of the spirit must have been a bitter one.

It was a singular circumstance that, at the period of my first visit to his harem, he was occupying a palace adjoining that in which resided another attainted noble-the Ex-Pasha of Bagdad! Both men of information-both blighted in their ambition, and bowed beneath the power they had defied - they amused the ennui of 
their monotonous existence with writing poetry; and moralizing on the instability of human greatness. I have remarked elsewhere that the Turks are seldom found wanting in philosophy.

As we did not arrive at the Pasha's palace for several hours after we were expected, it was supposed that some accidental circumstance had prevented our visit, and the family had consequently dined before we got there: but such an occurrence as this never causes the slightest inconvenience in a Turkish house, where the culinary arrangements are so regulated that you can command an excellent repast at whatever moment you may chance to require it.

On the present occasion, I rather regretted that the profuse and even sumptuous dinner that was served up to us was, from an excess of courtesy on the part of our entertainers, perfectly European in its arrangement, being accompanied by silver forks, knives, and chairs; but the luxury of the East had, nevertheless, its part in the banquet, for the cloth that covered the table was enriched with a deep border of exquisite needlework, and the napkins of muslin, almost as impalpable as a cobweb, were richly embroidered in gold. Wine was handed to us on a beautifully chased golden salver, and the glasses from which we drank it were of finely cut crystal; while the table stood upon a tapestry carpet. 
But the most beautiful objects employed during the repast were the silver basin, strainer, and vase, that were held by two black slaves for us to wash our hands, while a third stood a pace behind them, bearing upon his arm the napkin, wrought with a border of flowers in coloured silks, whereon they were to be dried. The vase, shaped like that from which Ganymede might have poured wine for Imperial Jove, was chased in the most delicate manner with grapes and vine leaves; and the same design enriched the border of the capacious basin.

As soon as we had dined, we adjourned to the private apartment of Heyminè Hanoum, at her especial invitation; when the young beauty, freed from the restraint of her mother's presence, clapped her hands, and ordered her pipe, which she smoked with as much grace and gusto as any Moslem of the Empire. They who cavil at this application of the word grace, have certainly never seen a young 'Turkish woman manage her chibouk - Nothing can be more coquettish!

The chapter on fans, so celebrated in the "Spectator," might be out-written a hundredfold by one competent to describe the manœuvres of an Eastern beauty, with her amberlipped and gold-twisted pipe. Such soft and studied attitudes — such long and slowly-drawn 
respirations, having all the sentiment of a sigh without its sadness-such clasping and unclasping of the delicate fingers about the slender tube - no novice should venture to smoke beside a Turkish woman, who is not satisfied to look as awkward as a poor mortal can desire!

We were all comfortably nestled among our cushions; and, on a small round table at the extremity of the apartment, stood a tray, bearing four wax lights. This custom of clustering the candles together is common in both Turkish, Armenian, and Greek houses ; and is peculiarly congenial to the indolence of Eastern habits, as it leaves such deep shadows in the distance, that those who have no immediate occupation to confine them to the vicinity of the glare may doze in undisturbed twilight on their sofas.

At intervals, a slave entered to trim the candles, or to replenish the pipe of Heyminè Hanoum; and each lingered awhile, unchidden, to listen to a fragment of the conversation, or to indulge in another gaze at the Frank strangers ; among the rest, one pale, languid-looking woman, who complained of sudden and severe suffering, and to whom the Pasha's daughter spoke even more kindly and gently than to any of the others, squatted down near the door, and remained a considerable time, with her head drooping on her bosom, apparently amused in spite of her indisposition. 
The slaves, both black and white, were innumerable-I should think that we had at least a score in attendance on us during dinner.

Despite the occasional interruptions that I have described, our conversation became gradually extremely interesting. The young beauty talked of Albania - of the proud and happy life that she had led there during her father's prosperity; and then of the misery which she had endured in exchanging its delights for the chilling observances and restraints of the Turkish capital. Had the heart of Heyminè Hanoum beat in the breast of her father, let the result have been what it might, he never would have recanted his rebellion.

From the political position of her family, she digressed to its social condition; and I was not a little amused by the perfect sang froid with which she entered into a detail of the domestic arrangements of the household.

"You have seen my brother ;" she said, " and I need not tell you that he is delicate and sickly. He was my mother's last child, and the Pasha feared that he should be left without a son. In this dilemma, he expressed to the Buyuk Hanoum his desire to contract a second marriage; but this she would by no means permit. She could not, however, avoid seeing that his anxiety was but too well founded: and she accordingly proposed a compromise, to which 
he at once agreed. Without loss of time, he wrote to a friend in Constantinople to purchase for him four young Circassians, and to embark them, under the charge of an elderly woman, for Albania.

"Young as I was, I shall not attempt to describe to you my mortification on their arrival. I saw the tears of my mother, which, when alone with me, she did not attempt to suppress; we had hitherto had but one heart and one interest in the harem of my father, and we became suddenly domésticated with strangers-women of another land and another language; to whom we were knit by no ties, bound by no sympathies.

"But all this is idle. You saw the Odalique who sat nearest to my mother? Allah has been gracious to her-she has borne two sons to the Pasha.-She with the large dark eyes, who when you entered was nursing her infant, has no other child than that one little girl. A third you will shortly see, when she pays me her visit previously to retiring for the night: I love her much, but she, poor thing! is childless. The fourth died in consequence of her sufferings during the passage to Albania, which was tempestuous and protracted. The aged woman who received you on your arrival was the person who accompanied the four Circassians from Constantinople, andbut here is Dilaram Hanoum."

VOOL. 1 . 
As she spoke, the curtain that shaded the door was pushed aside, and the Odalique entered. She was by far the prettiest woman of the three, but there was a subdued and hopeless expression about her, which showed at once that she had not been a favourite child of fortune. She was slight and beautifully formed, with a low, soft voice which was almost music. She appeared much attached to the lovely Heyminè, and hastened, after the first salutations were over, to replenish the pipe that rested beside the young beauty, and to hand it to her; a . mark of attention and respect which was acknowledged by its object with the graceful salutation common in the East-the pressure of the fingers of the right hand to the lips and brow.

The conversation was, of course, changed on her entrance; and the subject of jewels having been mentioned, Heyminè Hanoum despatched a slave for a handkerchief with which she was in the habit of binding up her hair, in order to show us one of the Albanian fashions. It was of black muslin, painted with groups of coloured flowers, and bordered all round with a deep fringe of fine pearls. I never in my life saw any mixture which produced a more striking effect; and when she wound it about her headthe dark glossy tresses of her hair relieved by the bright tints of the flowers, and the whiteness of her clear brow rivalling the pearls that 
rested on it - her crimson jacket, lined with sable, falıng back, and revealing the transparent chemisette of gauze, and the fair throat which it shaded - the pale blue silk trowsers trimmed with silver, and the small white naked foot that peeped for an instant from beneath them as she altered her position-I thought that earth could hold nothing more lovely than Heyminè Hanoum!

I was very busily engaged in examining an elegant hand-mirror set in a frame of chased silver, when a couple of negroes entered to invite us to the presence of the Pasha, who was awaiting us in his apartment. I have already mentioned that one room in the harem is appropriated to the master of the house, wherein he receives such of its inmates as he desires to converse with.

The message was scarcely delivered when the Buyuk Hanoum, whom the Pasha had desired to introduce us, entered the apartment, evidently somewhat surprised at the honour which was about to be bestowed upon two female Infidels. I had heard a great deal of the Scodra Pasha, and I naturally desired to see him; nor perhaps may it be amiss to impart to my readers a portion of his history.

Mustapha Pasha was residing on his Pashalik in Albania when Sultan Mahmoud reformed the national costume of the country, and replaced 
the lofty turbans and flowing garments of past centuries, with the scarlet fèz and frock coat of the present day. When the order for this change reached the Pasha, he at once communicated it to the troops, who resisted it with such violence as to threaten not only the liberty, but the life of their Chief if he persisted in its enforcement. In vain did he argue, explain, and persuade; the soldiery, wedded to their ancient usages, refused to listen to his reasonings ; their opposition being furthermore aggravated by a conscription, enforced with sufficient severity to lend them arguments against all concession to a power by which they were thus oppressed; and he finally found himself compelled to adopt a decided line of conduct in order to insure his own personal safety.

Already nearly in a state of siege in one of his palaces-surrounded by troops on whom he could by no means depend, seconded as they were by the people, in the indignation excited by the threatened infringement on theircherished habits -drawing the whole of his revenue from the soil - married to a lady of the country - possessed of considerable property within the Pashalikand threatened with death by an infuriated populace-it cannot be wondered at that Mustapha Pasha, thus hard pressed, resolved to assist his people in the struggle; and strengthening his army, and trusting to his mountain fastnesses, 
determined on a resistance to the Imperial will which at once placed Albania in a state of revolt.

It were tedious to detail at length the various fortunes of the rebel Pasha: a brave man, beloved by his troops, and sincere in the same cause-greatly assisted, moreover, by the mountainous and difficult character of the country naturally possesses the means of making head against a superior power to his own; and thus it was with the Scodra Pasha. Many abortive attempts were made to dislodge and capture him, by an army under the command of Reschid Mehemet Pasha, but in vain. He still held on his way, until at length the Sultan, irritated at the illsuccess of his endeavours, despatched Achmet Pasha with full power to act as a pacificator, and to use all possible means to recall the rebel chief to his allegiance, and an order not to return without having terminated the rebellion.

Thus instructed, the Imperial Envoy left the capital for Albania; and his attempts were not destined to be as fruitless as those of his predecessors. The rebel Pasha's army had fought for their lives as well as their privileges; they had gone too far to recede; and Achmet Pasha felt at once the utter futility of persisting in a system of violence which could produce no definite result. The character of his adversary was well known to him; it was high, honourable, 
and unsullied, save by his revolt against his Imperial Master ; and it was to this knowledge that he resolved to trust, in order to bring about a submission which the Sultan's arms were unable to effect. He accordingly despatched a messenger to Mustapha Pasha, by whom he requested an interview; and, to prove that no treachery was intended on the one hand, or feared on the other, he offered to place himself in the power of the rebel leader, by meeting him alone and unattended wherever he might appoint.

The Scodra Pasha, a man of amiable disposition and quick feelings, was touched by this mark of confidence, and unhesitatingly acceded to the request; when Achmet Pasha, without further delay, fulfilled the conditions which he had imposed upon himself, mounted his horse, and rode boldly off to the palace of the rebel. He was received with the utmost courtesy; coffee and pipes were introduced, and the two Pashas sat down side by side upon their cushions to discuss the important subject of their meeting.

To a man of Mustapha Pasha's good sense and sound judgment, it was by no means difficult for his visitor to demonstrate in the clearest manner the hopelessness of his situation. It was true that hitherto he had baffled all the attempts of the Imperial troops, by the wisdom of his measures, the judiciousness of his arrange- 
ments, the bravery of his own bearing, and the zeal of his soldiery. But this state of things could not last for ever - he was feeding upon his own strength, and his resources must ultimately fail-he had yet time to make a creditable and a free submission-he had still an opportunity to save his head-but, when he yielded from weakness, (and, should he persist in his rebellion, the bitter hour of helplessness must come;) how could he look for a mercy which he had rejected when it was freely extended to him?

Thus pressed, both by exterior argument and internal conviction; wearied also, it may be, of opposition to a sovereign whom he reverenced; the rebel leader asked time for deliberate consideration ere he returned a definite answer to the proposition-he stipulated also that an assurance should be solemnly given that his own life and those of his family should be spared; which Achmet Pasha did not hesitate to promise upon the spot. It was accordingly determined that the latter should remain two days in the palace of the rebel chief, when he should either depart alone, and unmolested, bearing with him the continued defiance of the revolted province; or that he should return to Constantinople accompanied by his host, and the females of his family, under the safeguard of his plighted word. 
The latter alternative was adopted ; and Achmet Pasha ultimately returned to Constantinople in company with the Scodra Pasha and his Harem. The fortune of the rebel chief was confiscated, and a hundred and twenty thousand piastres a-year settled upon him to supply the means of existence. But some time elapsed ere he was admitted to the presence, and allowed the high honour of kissing the foot, of his Sublime Highness.

On the same occasion he presented his two eldest sons, with whom the Sultan was so much pleased that he created them Pashas on the instant; and, having entered into conversation with them, he inquired how they liked the fèz, upon which the younger of the two, a fine boy of eight years of age, answered with a promptitude worthy of an accomplished courtier, that he had always liked it, but since he had seen it on the head of the Sultan, he should like it a thousand times better ; a reply which so delighted Mahmoud that he immediately presented him with a watch magnificently enriched with diamonds. Nor was the child less fortunate throughout the audience, for the smiling sovereign tried him with another question, to which he answered with even more point- " And which do you like the best, my young Pasha?" asked the Sultan: "Constantinople or Albania?"

"Constantinople," replied the boy ; "because 
you are here - the leaves cannot come upon the trees without the sun; and we cannot grow up to be brave men if we are not near you."

No wonder that Mustapha Pasha looks upon the mother of the boy as "the Light of the Harem."

The Buyuk Hanoum led us across the outer saloon to a spacious staircase, then across an upper hall, through a short gallery, and finally to the door of the Pasha's apartment. As I crossed the threshold, I was actually dazzled with light: the room was large; and was raised one step at the upper end, round which ran the sofa. Two tables, bearing trays of candles, were placed near the entrance; and a silver branch holding others was in the arched recess between them. The curtains and the covering of the sofa were of crimson satin, the latter fringed with gold a foot in depth, and furnished with cushions of gold tissue embroidered with coloured silk. At the extremity of the dais a pile of cushions were heaped upon the floor; and at the upper end of the sofa squatted the Pasha, with a negro slave on each side of him, busied in arranging his pipe which had been just replenished. A capacious mangal, heavy with perfume, occupied the centre of the floor.

Mustapha Pasha is still in the prime of life ; of the middle size, with an agreeable and sensi- 
ble expression of face, and a slight cast in one of his eyes. He received us very courteously, and ordered chairs for my friend and myself near his own seat, while he motioned the Buyuk Hanoum to be seated also; an intimation which she obeyed by placing herself on the extreme edge of the sofa. The next ceremony was to cause pipes to be presented to my companion and myself; the greatest honour that can be conferred on a female in Turkey being an invitation to smoke in the presence of the other sex.

'I'his was indeed a dilemma, for smoking had formed no part of my education; and I knew that, did I even raise the pipe to my lips, I should infallibly be ill; but the Pasha fortunately remarked the slight shudder and the gesture of repugnance with which $I$ took it from the hand of the slave; and he immediately requested me to refuse it, if I found it disagreeable, as he merely sought to pay me a compliment by offering it.

I need not say how gladly I availed myself of the permission, much to the amusement of the Pasha; who, after he had inhaled a few whiffs of his own chibouk, sent a second message to the harem, which was answered by the speedy appearance of Heyminè Hanoum and the favourite Odalique. A motion of his hand invited both to take their places upon the cushions already alluded to; and then 1 remarked the ascen- 
dency of the latter over the spirit of the Pasha-an ascendency due probably as much to her being the mother of his two sons, as to her natural shrewdness of intellect. Be that as it may, however, it was easy to perceive that she was a woman of great natural talent, and wonderful quickness of perception; and very likely to retain the supremacy that she had gained. The Pasha understood a little French, but did not attempt to speak it ; though it is probable that he will soon do so, as he is studying the language with unwearying perseverance. He has already formed a very respectable library, where he has collected together the works of Voltaire, Racine, Boileau, Molière, and many other standard authors; and he has done so thus prematurely, he says, in order that the sight of the volumes may stimulate him to industry; as he never looks towards them without reflecting on the riches that are hidden from him by his ignorance of the language, and which may one day be within his grasp.

I was astonished at many of the questions that he asked me; they were so unlike the generality of those to which I had already become accustomed in the country. He was very inquisitive on the subject of the Thames Tunnel -inquired as to its probable expense-the period at which it was likely to be completed-the width of the river at that precise spot-the 
amount of the toll to be paid by passengersthe mode in which the money had been obtained for its construction-in what manner it would be lighted-in short, he entered into every particular connected with the undertaking so earnestly, that I had reason to congratulate myself on being able to satisfy his curiosity.

He next asked a number of questions relatively to the Fire Insurance Companies of London, of which he had heard vaguely; and, when I had explained to him the whole of the system, he expressed his regret that no institution of the kind had been established in Constantinople; a want to which he was the more sensible as he had lately lost a house filled with valuable furniture and effects, of which he had been unable to save the smallest portion. He inquired if I thought that one of our Companies would consent to accept an insurance for his palace; as in the event of their being willing to do so, he would immediately take steps to make the arrangement. I explained to him the difficulty of inducing them to run so great a risk, aware as they must be of the frequency of fires in Stamboul, and the exorbitant interest they would require in the event of their consenting to his wish : when he at once allowed the objection to be perfectly reasonable, although he much regretted the necessity of abandoning the idea.

In the course of conversation, some allusion 
having been made to the philosophy with which he supported his reverses, his reply was so characteristic that it deserves record. "The chariot of my fortunes," he said, "had, for so long a time, run smoothly over the highways of life, that $I$ ought rather to feel surprise at its even pace during so many years, than wonder that its wheels should fail at last."

To comment on such an answer would be idle.

It was not without regret that I took leave of the Pasha, whose courteous manners and intelligent conversation rendered him a most agreeable companion ; and, had I been able to converse with him in his own language, I have no doubt that I should have been still more impressed in his favour. Before we quitted him, he invited us to spend a few days with the Buyuk Hanoum, and his daughter, during the marriage festivities of the Princess Mihirmàh, at a house which he had taken at the "Sweet Waters;" and, as we re-entered the harem, I could not refrain from expressing to the fair Heyminè my admiration of the intelligence and information of her father: But all praise of the Pasha to his daughter was "gilding refined gold, painting the lily, and throwing a perfume o'er the violet;" human commendations could not exalt him higher in her esteem.

If splendour could insure repose, we were des- 
tined to a long night of slumber beneath the roof of Mustapha Pasha, for our beds were one blaze of gold and embroidery ; and it is certain that the fair form which hovered about me until I sank upon my pillows had a most pleasant influence over my dreams; I never passed a more delicious night: I had visions of beauty, of which the lovely Heyminè was the type and subject: and if some faint impressions of strife and suffering mingled in the illusion, a bright smile and a soft glance dispelled the gloom, and brought back the light and the loveliness, that had been veiled for a moment, with tenfold lustre.

In the morning we returned to Pera, carrying. with us a store of pleasant memories for which we were indebted to this amiable family; and it was not without a very painful emotion that we learnt, in the course of the second day after we had quitted them, that the harem of the Pasha was dispersed in all directions, and the palace completely empty. The sick slave, whom I mentioned as having passed a considerable time in the apartment of Heymine Hanoum, had died the previous night of plague! 


\section{CHAP'TER XIV.}

Procession of Betrothal-Preliminary Ceremonies-The Mantle of Mahomet-The Palace of the Seraskier Pasha - The Palace Square Picturesque Groups-An Interior-Turkislı Children-Oriental Cıriosity-Costume of the Turkish Children - Military Music-The Procession-Hurried Departure of the Crowd-The Seraskier's 'Iower-The Fire Guard-Candidates for the Imperial Bride-Imperial Expedient_Saï Pasha-Policy of the Seraskier - $\mathbf{A}$ Andience -The Biter Bitten - Ingenious Ruse - Sublime Economy-Brilliant Traftic - The Danger of Delay - The Marriage Gifts - An Interesting Interview.

A Few days after my visit to the harem of Scodra Pasha, my father and myself started at nine o'clock in the morning to Constantinople, to be present at the procession consequent on the betrothal of the Princess Mihirmah, the Sultan's second daughter; a lovely girl of nineteen, about to be bestowed on Mohammed Saïd Pasha, who had been summoned from his Pashalik, at the Dardanelles, to receive at the hand of his Imperial Master this most honouring of all gifts.

But, before describing the procession, it may not perhaps be amiss to record some of the less public ceremonies of the betrothal, for which I am indebted to an eye-witness.

The day fixed upon for its celebration was 
the 7th of April; and, at the hour which the Court Astrologer had decided to be the most auspicious for the assembling together of the individuals necessary to its completion, who had received their notes of invitation two days previously from the Kislar-Aghasi (Chief of the Eunuchs), they met in the private apartment of the Imperial Treasurer, near the chamber that contains the holy Mantle of Mahometthe same sacred locality that witnessed the betrothal of the elder Princess. Here the whole company entered at the moment which had also been previously pointed out by the Astrologer as fortunate, and remained for some time in religious silence, in presence of the inestimable relic; after which each member of the distinguished circle seated himself upon the carpet that had been prepared for him.

The Grand Vizier, Mohammed Ronouf Pasha, took the upper place upon the sofa, having near him the Cheïk-Islam, (or High Priest) Mekki Zadè Moustafa Assim Effendi, who officiated on the august occasion. On the right sat the chief of the Eunuchs of the Imperial Seraglio, who acted as the proxy of the Princess; and whose witnesses were the Commissioner of the Imperial Treasury, and Osman Agha, one of the principal Eunuchs.-On the left was placed the adopted father and representative of Mohammed Saïd Pasha, the Seraskier-having for his witnesses, 
Halil Rifat Pasha, the Sultan's son-in-law, Akhmet Fevzi Pasha, Military Counsellor of the Palace, and Mohammed Saïd Pertew Effendi, Minister of the Interior, and Counsellor of State, with four others. Among the Cheirks and the men of letters who were admitted to this august assembly, to mingle their prayers with those of the Chè̈k-Islam, were Elhadj Yousouf Effendi, Chief of the Cheìks, and preacher at the great mosque of St. Sophia; and Elhadj Abdoullah Effendi, first chaplain of the mosque of Eyoub, and preacher at the mosque of Sultan Akhmet.

They were no suoner seated than the officers attached to the service of this chamber, which bears the name of Khirkaï.Chériff, presented to each person perfumes and rose-water according to the Eastern custom; and, when they withdrew, the doors were closed, and the ceremony commenced with a prayer by the Chèik-Islam, for the divine blessing on the union they were then assembled to celebrate; after which he put the customary questions to the proxies of the two contracting parties.

As soon as the act of betrothal was terminated, the doors were again thrown open, and the two Chèiks pronounced a prayer suited to the occasion. At the close of the prayer, the distinguished party quitted the Khirkaï-Chérif, and passed into a neighbouring apartment, VOL. I. 
where they partook of the refreshments provided for them, and were waited upon by the keeper of the Privy Purse, who presented to them the rich gifts with which his Sublime Highness was pleased to honour them. They then left the palace.

As soon as they had departed, the SultanaMother sent by the Bach-Agha (Eunuch and Major Domo) the nuptial offering of the bride to the bridegroom, who was awaiting it at the palace of the Seraskier, and superintending at the same time the arrangement of his own marriage present, which was to be conveyed with great pomp to the Seraï. The procession was to start from the palace of the Seraskier (the bridegroom's adopted father) at half-past ten o'clock, and we accordingly hired a window overlooking the line of march; whence we could see the train issue from the palace court, cross the extensive space in front of it, and finally lose itself in a narrow street leading to the Imperial residence.

The esplanade on which we looked down was crowded with horsemen, footmen, and carriages. Groups of women were squatted immediately in the rear of the soldiers, who lined the space along which the procession was to move; others occupied a raised platform erected by some speculative Moslem, whereon a place could be secured for the modest remuneration 
of a piastre, (two-pence halfpenny.) Rows of arabas, like beds of scarlet poppies, were ranged behind the pedestrians; while, further from the scene of action, parties were scattered over the whole square in the most picturesque confusion. Here a train of Serudjhis walked the horses that they had brought for hire; there a knot of Jews chattered and gesticulated; while their women huddled themselves up in the coarse cotton scarfs which concealed their head-dresses. On one side the snowy turbans and dark robes of half a dozen Ulemas formed a striking contrast to the green shawls bound about the brows of a group of Hadjïs, and their ample pelisses of crimson or maroon, lined and overlaid with fur. Here it was a party of soldiersthere a band of Bulgarians, dressed in jackets of sheepskin, with the wool turned inyvards, round caps of black lambskin, and leather leggings. Then moved by a score of Armenians, with their tall calpacs and crimson slippers-. jostled, as they passed slowly along, by a set of Franks, crushing and squeezing, as though they were resolved to carry their point, coute qui coute.

On a little hillock near the window that we occupied, a couple of 'Turks had sprear their carpet, and were quietly smoking their chibouks, attended by their negro pipe-bearers; while here and there a gigantic umbrella of white 
cotton overshadowed a round stand covered with sherbet and mohalibè, around which were clustered a throng of noisy Greeks, each with eyes as black as the shawl that he wore about his scarlet $f \dot{e} z$.

Nor was the scene within the room less characteristic than that without; the remaining windows had been hired by four grave-looking elderly Turks, who had brought with them half a dozen pretty little girls, of eight or ten years of age; who were sitting, doubled up at one corner of the sofa, with all the early taught awe and deference for the lordly sex which is the leading sentiment of the harem.

Our entrance, however, aroused them into something like action; for while our dragoman explained who and what we were, whence we came, and whither we were bound:-questions which are asked by the grave and bearded Moslem, as unceremoniously as by any one of our 'Trans-Atlantic brethren, and without the slightest suspicion on his own part that he is guilty of any impertinence-I made an easy acquaintance with the pretty children, by permitting them to handle the flowers in my bonnet, to touch my shawl, and to run their little plump fingers over my waist-ribbon. And when the grandee of the party who occupied the upper end of the sofa, whereon, moreover, his attendants had spread a carpet of 
crimson shag, fringed with gold, as though the ignoble chintz were not worthy the honour of receiving him, had taken the chibouk from his own mouth, and sent it by his pipebearer to my father-a mark of high consideration rather flattering than fastidious - and my father had, in his turn, despatched the dragoman, to spread before the children a feast of mohalibè, frosted over with powdered sugar, we were all the best friends in the world.

One of the little girls-a calm, self-centered, true Turkish child, with all the premature languishment and indolence so peculiar to the women of the country, with black, sleepy eyes, and lips like rose-buds-was clad in a jacket of purple velvet, lined with ermine, and laced with gold; her antery of pale pink muslin was tucked up within the cachemire shawl that she wore about her waist; and her large trowsers of green chintz fell in ample plaits over the little naked feet, which, when she rose from the sofa, were scarcely covered at the extremities by the yellow slippers that lay beside her.

Another, perhaps a year younger, had her jacket of crimson merino doubled with sable, and her little Symrniote fèz worked with seed pearls; her antery was yellow, her trowsers blue, and her chemisette of pale amber-coloured gauze. Nothing can be more outre than the costume of a little Turkish maiden: the long 
hair hanging in a score of minute braids, each confined at the extremity with a small knot of ribbon; the tight sleeves, open from the elbow, falling below the hip, and edged with elaborately wrought silk fringe; the round, white, dimpled feet; peeping out beneath the full trowsers; and the heavy jacket folding back from the ivory shoulders and snowy throat.

There is no distinction of dress between the child of two years old and the woman of twenty ; the same jewels, the same fashion, the same material, compose the one and the other; they differ only in quantity; the diamonds, except upon great occasions, are lavished on the children; and in fringe, and embroidery, and ribbon, they only yield to their elders, because there is not sufficient space upon their little persons to enable their parents to equalize the consumption between them.

At length, the distant sounds of military music came to us from the Palace court, and forth issued the Sultan's Band, playing his Grand March; this was succeeded by a regiment of the line, moving in double files: then rode forward about a score of staff officers, including several generals of brigade, and colonels of the Imperial Guard, surrounded by servants on foot; these were succeeded by two open carriages and four, empty-and after these came the presents of the bridegroom to the Imperial Family. 
First walked a hundred men of the Seraskier's establishment; about a score of whom bore upon their heads cages of wire, covered with coloured gauze, ornamented with flowing ribbons, and filled with sweetmeats of the most costly description, piled in porcelain dishes; the frosted sugar glittering in the light like jewels. Those were succeeded by others charged with silk stuffs of the most rare qualities, produced by the Indian looms-Cachemires of Tibet and Lahor - and other magnificent gifts, destined for the Sultan Mother.

The offerings to the bride followed. They consisted of two toilette services of massive silver, containing the most delicious perfumes of the East; a silver dinner service, arranged on a plateau of the same metal; several silver salvers covered with precious stones, and ornaments of gold and silver, and others heaped with gold coins : the whole covered with cages of silver net-work. Each of these bearers was attended by a page.

Then followed four more, having on their heads trays of shawls, folded in coloured muslin -and next came a dozen men, charged with all the articles necessary for the bath, under transparent coverings. One carried the pattens of ebony, inlaid with stars of mother-of-pearl, and clasped over the foot with a band of brilliants; another, the head-kerchief of silver tissue, em- 
broidered with wreaths of silken flowers; the third, a pile of silk napkins, fringed with gold, the fourth, a wrapping-cloth of flowered satin; the fifth, a capacious basin of burnished gold; the sixth, a comb of ivory, enriched with diamonds ; the seventh, a pair of slippers, wrought with emeralds and seed pearl; the eighth, a chemisette of pale pink gauze, edged round the bosom with silver fringe; the ninth, a cut crystal box clasped with gold, containing scented soaps ; the tenth, an ebony essence case, studded with rubies; the eleventh, a hand-mirror in a gold frame, surrounded by a garland of jewels; and the twelfth, a sofa covering of crimson velvet, flowered and fringed with gold.

Four eunuchs in brown and gold followed the presents; and were succeeded by an escort of sergeants of the line; after which appeared the Seraskier Pasha, surrounded by a brilliant staff, and preceding a second regiment of infantry, with the bright barrels of their fire-locks flashing in the sunshine, and attended by their band. These terminated the procession. But an interesting feature of the show still remained, when the led horses of the palace guests, each held by a groom, came prancing through the wide gateway, as if vain of their glittering housings and embroidered reins; the groups which had been scattered over the square were all in motion; the crimson-covered arabas began 
to move from their station; the sherbet-venders vaunted their merchandize, with voluble eagerness, to the passers-by - the Turks resigned their chibouks to their pipe-bearers, and rose from their carpets, which were instantly rolled up, and carried away by their domestics-the Bulgarians inflated their bag-pipes, and obstructed the path of the foot-passengers, with their heavy and awkward dance, which must have been modelled upon that of the bear-and, ere I had wearied of contemplating the scene, nine-tenths of the crowd that had so lately thronged the wide space beneath me had passed away.

The sunshine was lying warm and bright on the dome of Sultan Bajazet's mosque, with its portals of indented gothic; and its spiral minarets, with their galleries of rich tracerywork; dominated in their turn by the Tower of the Seraskier, which shoots up tall and white from an angle of the palace court, like the giant guardian of the locality ; and whose summit (to which we afterwards ascended) commands a series of the most magnificent views that the world can produce.

On one side, the City of Constantinople is spread out beneath you like a map; and you look down upon its thousand domes, and its five thousand minarets-upon its khans, and its charshees, its palaces and its prisons. Move a 
few paces forward, only to the next window, and the Sea of Marmora, with its peopled coasts, its rocky islets, and its glittering waves, carries your thoughts homeward to the "golden west." From one point you look on Mount Olympus, with its crown of snow; from another, on the sunny Bosphorus, laden with life, and langhing. in the day-beam. Turn to the left, and the Golden Horn, from whence the riches of the world are poured forth over the East, lies at your feet. On-on-ere your eyes ache with gazing, and your mind with wonder, and repose your vision on the dark and arid rocks which enclose "The Valley of the Sweet Waters," the most fairy-like glen that ever was hemmed in by a belt of mountains. And when you at length descend the three hundred and thirty steps of the dizzy Tower of the Seraskier, inscribe upon your tablets the faint record of an hour, during which, if you have sensibility or imagination, a love of the beautiful, or an appreciation of the sublime, you must have lived through an age of feeling and of fancy; with the busy, breathing city at your feet- the sweet, still valley beside you - and the wide sea, the unfathomable, the mysterious sea, bounding your vision.

What a pigmy is man amid such a scene as this!

I must not omit to mention that the Seraskier's Tower, called, by the 'Turks, Yanguen 
Kiosk, or Fire Tower, is the watch-house of the fire-guard. Six individuals are constantly on the look-out during the day and night, who relieve each other every hour; and, during the nightwatch, the guard constantly makes his round in a pair of spring pattens, which, being made of wood, and soled with iron, keep up a continual noise that prevents his giving way to drowsiness, and thus neglecting his duty.

There were seven equally eligible candidates for the hand of the Princess Mihirmàh ; and consequently more than seven times seven intrigues set on foot, when it was finally announced that the Sultan, her father, had resolved on bestowing her in marriage on some fortunate noble of his Empire. The Sublime Porte was all in commotion-the seven Eligibles all in agitationevery palace and harem on the qui vive-bribes flew about, on yellow wings, like the bright butterflies that herald spring - and the Sultan himself, weary of conflicting counsels and opposing interests, wavering and undecided; while many persons agreed in believing that the Imperial choice would ultimately fall on the handsome and wealthy Mustapha Pasha of Adrianople; and the rather as it was rumoured that the Princess had seen and admired him.

But Sultan Mahmoud, after a youth of terror and a manhood of blood, had become too good a tactician to risk offending many by ennobling 
one; and he consequently adopted an expedient which had assuredly never been contemplated by those about his person. He caused the names of the seven candidates to be inscribed on as many separate shreds of parchment; and on the following Friday, when he visited the mosque, he cast them all in a mass beneath his prayer-carpet, where they remained during the service; at whose close, he put up a prayer to Allah and the Prophet to aid him in the hour of trial, by enabling him to withdraw the name of the individual whose alliance would prove the most beneficial, alike to his Empire, and to his daughter. Whether the prayer was heard and answered, I know not; but the Sublime fingers closed over the parchment which was inscribed with the cypher of Said Pasha of the Dardanelles.

Saïd Pasha is a handsome man of three or four and thirty, with an expression of benevolence and amiability strikingly in his favour. He commenced his career at Court as Page to the Sultan, where he lost the favour of his master by refusing to obey a command which would have rendered him for a time the companion of grooms and serving-men; an instance of self-respect and self-appreciation so rare in 'Turkey, that it excited quite as much astonishment as indignation. Dismissed from the Court in disgrace, the young adventurer 
became a member of the sect of the Mevlavies, or Turning Dervishes; but, after the expiration of a year, he was recalled by the Sultan, and received a post in the army. Subsequently to this period, his rise to the Pashalik was rapid, as is generally the case in the East; and, on the last page of existence which he has turned, the characters may indeed be said to have been traced in gold.

After this hasty sketch of his history, it is scarcely necessary for me to add that Saïd Pasha left the Dardanelles a poor man ; nor to remind my readers that a titled Lackland was no meet match for a Sultan's daughter. The evil cried aloud for remedy, and the cure came as speedily as its necessity had arisen.

The Seraskier had adopted Halil Pasha as his son, on the occasion of his marriage with the Princess Salihè, two years ago; and had been to him a most munificent father; in the present difficulty he again stepped forward, and the portionless Saïd Pasha beheld himself at once a rich man.

Upon the Seraskier it then devolved, in his double capacity of High Minister and Parent, to introduce the fortunate bridegroom to his Imperial father-in-law; and the recollection of all that the wily old courtier had done for the object of his first adoption, produced very different feelings in the breasts of the two indivi- 
duals, more immediately interested in the financial arrangements of the marriage.

"I present to your Sublime Highness," said the minister, "the son-in-law whom Allah has destined to the high honour of becoming the husband of your Imperial daughter - Saïd Pasha, my adopted son-and I do so with the greater delight that I know him to be as brave in the field, as he is wise in the cabinet-as mild in temper, as he is courageous in spirit-learned, gentle, submissive, and enthusiastic, in his attachment to your Sublime Highness (May your end be glorious!) He has every virtue under heaven, and but one defect."

"And what may that be?" inquired the Sultan, arching his dark eyebrows in astonishment. "It must be weighty indeed if it can counteract the effect of so bright a list of qualities."

"Alas! your Sublime Highness-" replied the Seraskier, "Saïd Pasha is poor!"

The point was pathetic enough; and the politic minister, who would gladly have secured the honour of being the adopted father of the Sultan's second son-in-law, without paying quite so high a price for it as he had done on the marriage of his first, flattered himself that a recollection of the enormous outlay which he had made on that occasion would exonerate him from a similar expence on the present. But the Sultan had 
doubtlessly learnt that the diamond can be cut only with its own dust; and he acted upon that principle, as he blandly answered, if not in the words, at least in the feeling, of our immortal bard :-

'Tis true, 'tis pity, and pity 'tis, 'tis true;

"But, while he has the wealthy and munificent Seraskier of the Sublime Empire for his adopted father, he must remain unconscious of the fact."

The Minister did all that have remained for him to do-he tried to look flattered and gratified - he even returned thanks for the gracious words which taught him to understand all that was expected of him: and he left the Presence to withdraw, from his strong box, ducats to the amount of two millions of piastres, which were bought up by the Frank Merchants at Galata.

But the best part of the jest was yet to come. On the marriage of one of the Imperial Family, erery Pasha of the Empire is expected to present an offering proportioned to his means; and, as these generally consist of jewels, the Chamberlain acquaints each individual, on learning the amount of his purposed present, with the most acceptable shape in which he can make it; and by these means prevents the chance of a too frequent repetition of the same gift.

When the Princess Salihè became the wife of Halil Pasha, the amount of her diamonds thus 
obtained was very considerable; and, as she is a person of too morose and selfish a character to take pleasure in showing herself to the people as the sisters of the Sultan are in the habit of doing; and, moreover, too haughty to seek to dazzle even in the harem, his Sublime Highness, who is an admirable tactician, bethought himself of a most brilliant plan for making a little money in a quiet way out of these anti-engaging qualities.

He accordingly paid a visit to his daughter ; and after she had enjoyed the high honour of kissing his foot, and he had graciously signified to her his Imperial permission that she should seat herself upon the cushions piled on the floor near him; he condescendingly explained to her the utter uselessness of jewels which she never wore, and suggested the expediency of her disposing of them, and adding the interest of the sum that they would produce to her present income.

The Princess listened in respectful silence; and then ventured to doubt whether a purchaser could be found for the diamonds of a Sultan's daughter. This difficulty was, however, instantly overcome, by an offer, on the part of his Sublime Highness, to become himself that purchaser. And the consent of the Princess having been obtained, and the price to be paid decided on, the principal remained in the Imperial Trea- 
sury, whence the interest was to be drawn; and the jewels, thus, in point of fact, obtained for a per centage on their value, were carried off in triumph by the court jewellers, to be reset for the younger Princess!

Nor was this all - for, when the Pashas declared the amount of their offerings, the money was paid on the instant, and these very diamonds given in exchange, fashioned into such forms as best suited the taste and convenience of their new owner.

Thus were things situated when the baffled Seraskier withdrew from the Imperial Presence, to drag his beloved ducats from their snug restingplace in his strong box, and to scatter them among the money-changing Franks. Many of the Pashas had not yet come forward with their gifts, and he had still breathing time for a shrewd stroke. It is the fashion at the Sublime Court for each noble to announce the amount of the present which he purposes to make; and the declaration generally exceeds the actual value of the offering by fifty or a thousand piastres. The Seraskier accordingly collected these declarations, and having so done, he addressed a courtly circular to the tardy (in this case tootardy:) Pashas, informing them that his Sublime Highness Mahmoud "The Powerful," the Light of the World, and Brother of the Sun, had so overwhelmed his intended son-in-law, Mohammed Saïd Pasha,

vOL. 1. 
with the brightness of his munificence, that he had rained diamonds upon him, and overstrown his path with precious stones; and, such being the case, he, the Seraskier, acting as his adopted father and counsellor, had suggested to him the expediency of proposing to those Pashas who had not yet honoured him with their gifts, to make them in the current coin of the Empire, rather than in diamonds which could not, under the circumstances, avail him any thing.

The suggestion was a command; the wily Seraskier held the list of names and offerings ; and each Pasha was under the necessity of coming forward, and paying to the treasurer of the Seraskier the actual sum in money which he had specified!

Nothing sharpens the wits of a Turk like selfinterest.

The procession, from which I have digressed, passed through the street called Divan-Yoli, terminating at the mosque of St. Sophia, near the Imperial Palace. When it arrived at Ortakapou, or The Middle Door, the whole of the officers alighted, and formed an avenue to the entrance of the harem, whence the marriage gifts were conveyed into the Seraï, where the Seraskier, acting for the bridegroom, craved and obtained an interview with the Kislar-Agha, who was proxy for the Princess. This hideous negro has the thickest lips, the flattest nose, the smallest 
eyes, and the most unwieldy person of all the eunuchs of the empire. Imagination cannot paint his ugliness! And before this revolting caricature of humanity, the haughty Minister, in whose hands are life and death, bent his stubborn knee in supplication. Scarcely had he crossed the threshold of the magnificent apartment in which the Kislar-Agha awaited him, ere he prostrated himself to the earth, as he besought the monstrous representative of youth and beauty to have mercy upon the slave who kissed the dust before the Light of the Creation, the Glory of the Moon,* the Empress of his thoughts - upon which the unwieldy negro averted his face, cast down his eyes, and assumed the prude; but, after a vast deal of coquetting, the lover-like vehemence of the gray-headed Seraskier met with its reward-a sable hand was extended towards him, which he embraced with transport - the presents were condescendingly accepted; the sweetmeats by the Kislar-Agha himself: and the more costly offerings by the principal eunuchs of the palace, in the names of their Imperial Mistresses, to whom they were immediately conveyed.

And thus terminated the first act of the sublime comedy!

- Mihirmàh, the glory of the moon. 


\section{CHAPTER XV:}

Fine Scenery-The Coast of Asia-Turkish Cemeteries-The Imperial

Serai-The Golden Horn-Mount Olympus-The Arabajhe-The Araba-The Persian Kiosk-The Barrack of Scutari-The Mosque of Selim III.-The Slipper of the Sultana Validè-The Imperial Guard - Military Material-The Macaroni Manufactory-Sublime Targets -A Major of the Imperial Guard-Triumph of Utilitarianism - The Rise of the Vines-The Holy Tomb - Encampments of the Plaguesmitten-The Setting Sun-Return to Europe-The Square of Topplıannè.

I Have seldom seen a lovelier day than that on which we first passed over to Scutari; the sunshine was bright upon the Bosphorus, the tops of the tall cypresses were golden in the light, and their feathery branches heaved slightly beneath the breeze; the sky was blue about the spiral minarets : and the painted houses gleamed out like gigantic flowers as the daybeam touched them ; the ripple sparkled like diamond-dust, and our arrowy caïque seemed to breathe as it undulated upon the surface.

It was a glorious scene! And we were soon upon the bosom of the blue waters, darting along, with the wild birds above our heads, out into the Sea of Marmora. Europe was 
beside and behind us-Europe, with its palaces, its politics, and its power - and the shadowy shore of Asia, with its cypress-crowned heights, and its dusky mountains, seemed to woo our approach. How I regretted that the passage was so brief-a few strokes of the oar, a few pulsations of the heart, after we had shot past the "Maiden's Tower," and we were landed beside the ruined mosque, in the valley beyond the Persian Kiosk of the Sultan, which crowns the crest of the highest hill.

The land curved gracefully downward at this point to form a fair green glen, where a group of plane trees and acacias threw their long branches over the remains of the crumbling temple. Here and there a solitary cypress shot up its dark head like a death-lance into the clear horizon, contrasting its funereal and gloomy pomp with the laughing clusters of the pinkblossoming almond-trees, which were scattering their petals over the grave-stones that rose on the side of the grassy bank amid the wild flowers, as if to link the present with the past.

It is a beautiful custom, that of burying the dead upon the very path of the living! It destroys so much of the gloom which imagination is prone to drape about the grave-it creates so much more of a common interest. 'The 'Turk smokes his chibouk with his back resting against a turban-crested grave-stone ; the Greek spreads 
his meal upon a tomb; the Armenian shelters himself from the sunshine beneath the boughs that overshadow the burial-places of his people; the women sit in groups, and talk of their homes and of their little ones among the ashes of their ancestors ; and the children gather the wild flowers that grow amid the graves, as gaily as though death had never entered there.

The caïque soon darted into the little bay, and we trod the shore of Asia. Immediately in front of us, on the European coast, stretched the long castellated wall of the ancient city of Constantine, with its Seven Towers, and its palace-girdled Point. Nothing could be more beautiful! The numerous buildings of the imperial Seraï were overtopped by shadowy planetrees, leafy beeches, lofty cypresses, feathery acacias, and other magnificent forest trees; from amid whose foliage the gleaming domes and gilded spires of the palace peeped out like glimpses of fairy-land. (On the extreme point of the shore stands that portion of the Seraglio which was formerly appropriated to the ladies of the Imperial Harem, but which is now untenanted, save by half a dozen old and withered women, the surviving wives of the unfortunate Sultan Selim. The sun had touched it, and was reflected back in brightness from its gilded doors and glittering lattices. It looked like a 
eluster of kiosks gracefully flung together in the hour of sport.

Beyond that point lay the Golden Horn ; and, along the summit of the hill which shuts it in on the opposite shore, stretched the cypress-grove and houses of Pera. But ere long we turned away from these accustomed objects to glance upwards to the crest of Mount Olympus, far, far away in the distance, forming a mighty background to the Sea of Marmora. We saw it at a happy moment, for the sunbeams had turned its snows to jewels, which were flashing with a brightness that almost forbade our gaze; when suddenly a light cloud passed over its stately brow, and, deadening for an instant the glitter that it had borrowed from the day-beam, sobered down its tints into more subdued beauty, and made it look as though it were girdled by a rainbow.

As we reluctantly quitted this fair scene, and walked towards the valley, we saw the araba that we had appointed to await us there, standing beneath the shade of the tall trees; and as the arabajhe observed our apprcach, he rose from his seat beneath a stately elm, laid aside his chibouk, and prepared to assist us into the carriage. But I lingered yet another moment to contemplate his costume-his voluminous turban, which it must have required ells of muslin to produce; and his gaily-tasselled and 
embroidered jacket, falling back to disclose the shawl that bound his waist. I scarcely knew which to admire the most;-his black and bushy beard, and the thick mustachioes that adorned his upper lip; or theelaborately-wrought Albanian leggings and yellow slippers which completed his costume.

No one but a native of the luxurious East could ever have invented an araba; with its comfortable cushions, and its gaily painted roof, and gilded pillars. The prettiest are those of brown and gold, with rose-coloured draperies, through which the breeze flutters to your cheek as blandly as though it loved the tint that reminded it of the roses of the past season amid which it had wandered.

As we clomb the hill, we passed beside the Imperial kiosk, a delicate little edifice with walls of pale green, and snow-white jalousies; and then, descending a slight acclivity, we found ourselves opposite the magnificent barrack, which forms so fine a feature from the sea. There is probably no country in the world where the barracks are so elegantly built as in Turkey; they have all the appearance of palaces; and that of Scutari being appropriated to the Imperial Guard is the handsomest in the neighbourhood of the capital; being a quadrangle, flanked with square towers, built in three sections, gradually diminishing in size, 
and crowned by a slight spire. Immediately opposite to the principal gate of the barrack stands the magnificent mosque of Selim III.; but Scutari, among the numerous temples whose slender minarets are relieved by the dark back ground of her funereal cypresses, possesses one of which I must not forget to make mention. Small in size, and not particularly elegant in its appearance, the mosque of the Sultana Validè must not be passed over in silence, built as it was from the proceeds of one of her diamondsprinkled slippers!

I have mentioned that this barrack is occupied by the Imperial Guard: and I never shall forget their appearance, as groups of them passed us on the road. Dirty, slouching, and awkward, many among them without either shirts or stockings, they certainly looked as unlike Household Troops as can well be imagined; and might have traversed three quarters of Europe without being mistaken for soldiers at all, either by their gait or their garb. When on duty, and not examined too closely, they make a fair figure as a body, but on ordinary occasions they are as unmilitary in their appearance and bearing as the rest of the Turkish army; and the majority of them are such mere boys that they induce a feeling of pity rather than fear. On one occasion, when I paid a visit to the Sultan's sister, while waiting to be admitted, I 
amused myself by looking attentively at the palace-guard, who had all collected outside the guard-house to see the Franks; including the two sentinels on duty, they amounted to ten individuals; and certainly eight of the number ere not more than fourteen years of age; nor do I believe that any of them had washed their faces, or brushed their garments for a week previously.

A Pasha, while speaking with me one day of the Turkish army, assured me that it was composed of " excellent materials." - It may be so ; I cannot, nor do I desire, to confute his opinion; but it is certain that, like other raw materials, it will require a great deal of working before it can be rendered serviceable; and that, at present, there are few things more laughable than to see a Turkish regiment at drill or exercise; there is an independence of feeling and action about each individual which is quite impayable.

But the surprise created by the appearance of the Imperial Guard was not to be the only cause for astonishment excited by this gallant corps; for we were yet indulging a hearty laugh at their expense when we were startled by the recommendation of the arabajhe that we should visit the Macaroni Manufactory of Achmet Pasha. At first we thought that our dragoman had played us false, for we could 
find no possible connection in our own minds between the Generalissimo of the Armies of the Sublime Porte, and a Macaroni Manufactory. The invitation had, however, been correctly interpreted, and we immediately diverged from the road to see this highly-connected establishment.

On rising a little hill, we entered the widest street that I had yet seen in the East, partly overshadowed by the stately trees which encircled an ancient mosque, and terminated by the principal entrance to the garrison.

I may as well mention here that the main portal of every 'Turkish barrack is decorated with a target, richly framed, and perforated with one or more balls, shot by the Sublime hand of the Sultan, who is an excellent marksman; and thus seeks to excite by his example a feeling of emulation among his soldiery.

The araba drew up before a neat-looking white building with a green balcony, and, ere we could alight, the door was opened to us; when one of the gentlemen of the party instantly recognized an acquaintance, to whom he hastened to present us; and I in turn made my bow to a Major of the Imperial Guard, with a diamond decoration on his breast, his sleeves tucked up to the shoulders, and his arms buried to the elbows in flour.

The Turks are utilitarians indeed! 
The scene was a singular one; the large hall in which we stood was entirely over-canopied with ropes of macaroni, and surrounded by presses and rollers.-A major was deciding on the merits of the flour-a lientenant was superintending the working of the machine-a couple of sergeants were suspending the paste to dryand a fatigue party were turning the wheels.

Hear this, ye Grenadiers and Coldstream! ye exquisites of Bond Street and the Ring! There was no ennui here-all was grinding, and sifting, and rolling, and drying, and sellingyes, selling-The Imperial Guard of his Sublime Highness have no occasior to kill time; they rather seek customers. The whitest and finest of the paste supplies the kitchen of the Sultan: the darkest and coarsest finds its way to that of the soldiers; but "more remains behind ;" and if you are inclined to feast on Imperial macaroni, you have but to draw out your purse, and pay it in piastres!

What a well-imagined antidote to the weariness of a garrison life-What a triumph for utilitarianism!

I shall say nothing of the forest-like cemetery; I have spoken of it elsewhere. The dark cypresses were flinging their long shadows across the road; and the hill which we slowly ascended on quitting the manufactory was called "The Rise of the Vines." The name is appropriate; 
for the houses that fringe it on the left hand overlook a wide extent of orchard and vineyard, interspersed with kiosks, and groups of flowering acacias. The view was bounded by the sea, and the tall mountains above Broussa: and flowers were blossoming by the wayside, and wild-birds were singing among the boughs. No wonder that the nature-loving Turks are attached to Scutari.

A small building to the left of the road attracted my attention, and I alighted to examine it. It proved to be the tomb of a Saint; and I distinguished, through the closely-latticed casement, a wooden sarcophagus surmounted by a green turban, and surrounded by the prayercarpets of the priests. The wire-work of the window was knotted all over with rags ; shreds of cotton, woollen, and silk - morsels of ribbon and tape - and fragments of every description. They had been fastened there by sick and suffering persons, who had firmly believed that their trouble, whether mental or physical, would remain attached to the rag, and that they should themselves "return each to his home clean."

We avoided the town, for the Plague was there; that omnipresent but invisible enemy which stretches its clammy hand over the East, and sweeps down its prey, unchecked by the groans of the bereaved, or the pangs of the smitten - the deadly Plague, which spares 
neither sex, nor age, nor condition; but makes one universal harvest of mankind.

Nothing ever thrilled me more than when I once came suddenly, during my wanderings, upon an encampment of the Plague-smitten. The huts are generally erected on a hill-side, and the tents pitched among them; and you see the families of the infected basking in the sunshine within their prescribed limits, and gazing eagerly at the chance passenger, whom his ignorance of their vicinity may conduct past their temporary dwellings; the children rolling halfnaked upon the grass ; and the sallow and careworn parents hanging out the garments of the patients on the trees of the neighbourhood. Such was precisely the case with that into which I had unconsciously intruded; and whence I was very hastily dislodged by the shouts of the guard, stationed to enforce the quarantaine of the mountain colony; and the alarmed exclamations of my companions.

It is difficult to look upon such a scene, and upon such a sky; and to believe in the existence of this frightful scourge! It is the canker at the core of the forest-tree-the serpent in the garden of Eden.:

The sun was setting ere we prepared to traverse the Golden Horn, in order to reach the European side before the firing of the evening gun; the shadows were lying long upon the water: 
a yellow gleam was settling on the clomes and houses of Stamboul, and a thick vapour lowered over the sky. The twilight of the East is fleeting as a thought-and the outline of the city ere long loomed out from amid the gathering darkness, like a spectre of the past. One line of light still glimmered across the waves like a thread of gold, linking the shores of Europe and of Asia; but, even as I pointed it out, it faded; softening down to a faint yellow, like the lip of a primrose-and in another instant, it was gone; while, as it disappeared, the hoarse cannon pealed over the ripple, and told that another day was spent.

Our rowers had calculated to a nicety, for, as the sound died away, the caïque touched the crazy wooden pier of Topp-hannè, and we were once more in Europe!

There is not a locality throughout the whole of the capital more strictly or more richly oriental in its aspect than the small square of Topp-hannè. In the midst stands the celebrated Kilidge Ali Pasha Djiamini, or Fountain of the Mosque of Ali Pasha, a French renegade; who built the temple which bears his name. Constantinople boasts no other fountain' of equal beauty. Its rich and elegant arabesques are beyond all praise; and, when the sun is shining on them, almost look like jewels. It has, however, suffered materially from the reforming 
mania of the Sultan, who, in his rage for improvement, has replaced its wavy and deeplyprojecting roof with a little terrace railing, out of all keeping, alike with its architecture and its ornaments; and who was with difficulty persuaded not to destroy it altogether.

On one side of the fountain is the mosque to which it belongs, and on the other the kiosk of Halil Pasha, with its magnificent portal and glittering casements. But to be seen to perfection, the square of 'Topp-hannè must be visited during the autumn, when the rich fruits of Asia are scattered over its whole extent; piles of perfumed melons, pyramids of yellow grapes, heaps of scarlet pomegranates - the golden orange, the amber-coloured lemon, the ruddy apple, the tufted quince, all are poured forth before you. Nor are the vendors less various or less glowing than their merchandize, as they sit doubled-up upon their mats, clad in all the colours of the rainbow, with their chibouks between their lips; rather waiting than looking for customers - a bright sky above them, and the blended languages of many lands swelling upon the wind.

Had I landed at Topp-hanne on my arrival in Turkey, I should have fancied myself a spectator of one of the scenes described by the taletelling Schererazade. 


\section{CHAPTER XVI.}

Turkislı Superstitions-Auguries - The Court Astrologer - The Evil Eye-Danger of Blue Eyes-Imperial Firman-The Babaluk-The Ceremony -Sable Pythonesses - Witcheraft.

The Turks are strangely superstitious; they cling resolutely to the absurd and wild fancies which have been banished from Europe for centuries; and that too with a blindness of faith, and a tenacity of purpose, quite in keeping with their firm and somewhat dogged natures.

Many of their superstitions they inherit from the Romans; they extract auguries of good and evil from the entrails of fresh-slaughtered animals-they draw inferences from the flight of birds-they have auspicious and inauspicious hours, which are gravely determined by the Astrologers; and no Osmanli ever undertakes a journey, builds a house, marries a wife, or commences any business of importance, without satisfying himself on this important point. Should evil or disappointment overtake him, despite the precaution he has used, he never blames either his own mismanagement or anovOL. 1 . 
ther's treachery; neither does he sink beneath the trial: he tells you that it is his kismet-his fate-and he calmly submits to what he considers to have been inevitable; and should misfortunes accumulate about him, instead of attributing them to worldly causes, he ascribes them to his felech-his constellation-without searching further.

When he is troubled with unpleasant dreams, haunted by melancholy fancies, or suffering from bodily disease, he tears away a fragment of his dress, and fastens the rag to the iron-work of a window belonging to the tomb of a saint, in order to deposit the evil along with it. When he is sick, he procures from the Priest an earthen bowl, inscribed throughout its interior with passages from the Koràn; and, filling it with water, sets it aside until the whole of the writing becomes effaced, when he swallows the liquid, and thus administers to himself a dose of Holy Writ! The Court Astrologer publishes every year a species of supernatural almanack, in which he specifies the lucky and unlucky days of the different moons ; foretells wars, deaths, and marriages; and imparts a vast quantity of multifarious information, which must be both valuable and curious, if it is to be estimated by the price paid for it, as the salary of the Seer is a most liberal one.

A nother singular superstition common through- 
out Turkey is the belief that should a dog chance to pass between two persons who are conversing, one or the other will fall sick unless the animal be propitiated with food; and the first care of a Musselmaun to whom this ill-luck has occurred, is to look about him for the means of averting its effect.

But the predominant weakness of the East is the dread of the Evil Eye. Should you praise the beauty of a Turkish child to its mother, without prefacing your admiration with "Mashallah!" or, In the name of God-which is considered sufficient to counteract the power of all malignant spirits; and, should the child become ill or meet with an accident, it is at once decided that you have smitten it with the Evil Eye. The Greeks, when by accident they allude to their own good health or good fortune, immediately spit upon their breasts to avert the malign influence; and to such a pitch do they carry their faith in the efficacy of this inelegant exorcism, that on a recent occasion, when an acquaintance of my own was introduced to a beautiful Greek girl, and betrayed into an eulogium on her loveliness, he was earnestly entreated by her mother to perform the same ceremony in the very face which he had just been eulogizing, in order to annul the evil effects of his admiration ; and so pressing were her instances that he was compelled to affect obedience to her wishes, ere 
she could be re-assured of the safety of her daughter!

The Turk decorates the roof of his house, the prow of his caïque, the cap of his child, the neck of his horse, and the cage of his bird, with charms against the Evil Eye; one of the most powerful of these antidotes being garlic: and it must be conceded that, here at least, the workers of woe have shown their taste. Every hovel has its head of garlic suspended by a string; and bouquets of flowers formed of spices, amid which this noxious root is nestled, are sent as presents to the mother of a new-born infant, as a safeguard both to herself and her little one.

A blue eye is supereminently suspicious, for they have an idea that such is the legitimate colour of the evil orb; and you seldom see a horse, or a draught ox, or even a donkey, which has not about its neck a string of blue beads; to preserve it from the dark deeds of witcheraft. I was considerably amused on one occasion, when, being about to meet the carriage of a friend, the horse that drew it, either from idleness or caprice, suddenly stood still, and the arabajhe exclaimed with vehemence to his mistress, "You sec, madam, you see that the horse is struck - the new Hanoum has blue eyes!" turning his own on me as he spoke, with a most unloving expression. I am perfectly convinced that, had the animal met with 
any misfortune, or been guilty of any misdemeanour during the remainder of the day, the whole blame would have inevitably been visited on my unlucky eyes, which had counteracted the effect of a row of glass beads, and a crescent of bone!

To protect the reigning Sultan from the power of the Evil Eye during his state progresses through the streets of the capital, a peculiar headdress was invented for the Imperial body-pages, whose ornamented plumes were of such large dimensions as, collectively, to form a screen about his sacred person. Even Sultan Mahmoud, who is superior to many of the popular prejudices, has just caused a Firman to be published, prohibiting the women from looking earnestly at him as he passes them, on pain of-what think you, reader? - of subjecting their husbands or brothers to the bastinado! The Turkish laws are too gallant to condemn females to suffer this punishment in their own persons, and Mahmoud is consequently to be protected from the possibly fatal effects of the ladies' eyes by their fears for their male relations.

Another singular custom is that of pouring water where any one has fallen, to prevent a recurrence of the accident on the same spot, which is religiously observed by the lower orders ; as well as flinging stones at the body of a decapitated criminal, in order to sccurc the 
dreams of the spectator from an intrusion of the ghastly object.

No Turk of the lower ranks of society ever passes a shred of paper which may chance to lie upon his path; he always gathers it up with the greatest care; as the popular belief leads him to place implicit faith in an ancient superstition that all paper thus obtained will be collected after death, and scattered over the burning soil through which he is to pass to paradise; and that consequently the more he is enabled to secure, the less suffering he will have to endure hereafter.

A most extraordinary fact came to my knowledge a short time before I left the East, relatively to the female Arabs of the harem. They have a species of society, or institution - I scarcely know how to term it - in which they are initiated from their girlhood, that they call "Babaluk," whose principle of mystery is kept as secret as that of freemasonry; while the occasional display of its influence is wild and startling enough to remind the spectator of the Priestesses of Delphi.

Far from affecting any concealment of their participation in the pretended powers of the society, you cannot, when a guest in the harem, please an initiated Arab more surely than by inquiring if she be a Babaluk; and the Turkish ladies frequently amuse themselves 
and their visitors by exhibiting their black slaves while under the influence of their selfexcited phrenzy. When a sable Pythoness is informed of the wish of her mistress, she collects such of her companions as are Babaluks, for there are sometimes several in the same harem, and a brazier of burning charcoal is placed in the centre of the saloon in which the ceremony is to take place. Round this brazier the Arabs squat down, and commence a low, wild chant, which they take up at intervals from the lips of each other; and then break into a chorus, that ultimately dies away in a wail, succeeded by a long silence, during whose continuance they rock their bodies backwards and forwards, and never raise their eyes from the earth. From the moment in which the chant commences, an attendant is constantly employed in feeding the fire with aloes, incense, musk, and every species of intoxicating perfume.

After a time, they fall on the floor in a state of utter insensibility, and great exertion is frequently necessary to arouse them from their trance; but, when once they are awakened, they become furious-they rend themselves, and each other - they tear their hair and their clothing - they howl like wild beasts, and they cry earnestly for food, while they reject all that is offered except brandy and raw meat, both of which 
they destroy in great quantities. Having satisfied their hunger, they renew the warfare that they had discontinued to indulge it, and finally roll on the floor with bloodshot eyeballs, and foaming at the mouth.

A second trance ultimately seizes them, from which they are left to recover alone; fresh perfumes being flung into the brazier to expedite their restoration, which generally takes place in ten or fifteen minutes; and then it is that the spell of prophecy is on them. They rise slowly and majestically from the floor-they wave their hands solemnly over the aromatic flame-they have become suddenly subdued and gentle; and, after having made the circuit of the brazier several times in silence, they gaze coldly round the circle, until, fixing upon some particular individual, they commence shadowing forth her fate, past, present, and to come; and I have heard it seriously asserted that they have thus divulged the most secret events of by-gone years, as well as prophecying those which subsequently took place.

It is scarcely wonderful-even disgusting as a great portion of the ceremonial undoubtedly is-that many of the Turkish ladies occasionally relieve the tedium of the harem by the exhibition of the Babaluk; that vague yearning to pry into futurity so inherent in our nature, coupled with the uncertainty on whom the spell 
of the sybil may be cast, causes an excitement which forms an agreeable contrast from their customary ennui. No second fate is ever foretold at the same orgies. When the first Babaluk begins to speak, the others sink down into a sitting posture, occasionally enforcing her assertions by repeating the last words of any remarkable sentence in a long, low wail; and, when she ceases and takes her place among them, they are for the third time overtaken by a trance: the brazier is then removed, the spectators leave the room, the door is carefully closed, and the Babaluks are left to awaken at their leisure. When they finally come forth, they resume their customary avocations, without making the slightest allusion to the extraordinary scene in which they have been actors; nor do they like the subject to be mentioned to them until several days have elapsed. 


\section{CHAPTER XVII.}

Imperial Invitation - Disagreeable Adventure - Executed CriminalEfficacy of Wayside Executions - Tardy Conversions - Mistaken Humanity - Summary Mode of Execution - The Palace of Asmè Sultane-Entrance of the Harem-Costume of the Slaves-Nazip Hanoum-Ceremonious Recepiion-The Adopted Daughter-Costume of the Ladies of the Serai-Beauty of the Slaves-Extraordinary Arrangement - Rejected Addresses - The Imperial Lover Sacredness of Adoption in Turkey - Romantic CorrespondenceLadies of the Household - The Mother of the Slaves-Peroussè Hanonm-Crowded Audience-The Imperial Odalique-Music of the Harem - The New Pet-The Kislar-Agha-The "Light of the Harem "-The Poetical Sultan-Indisposition of the Sultana-The Palace Gardens-The Imperial Apartments - The Dancing GirlReluctant Departure-Ballad by Peroussè Hanoum.

Having received an invitation to wait upon Asmè Sultane, the elder sister of the Sultan, at her summer palace, I started from Pera early one morning accompanied by a friend, to obey the Imperial summons.

The weather was beautiful ; the great Cemetery was crowded with loungers, and the road leading to "The Sweet Waters" thronged with horsemen. The spring flowers were bursting, and the young leaves trembling in the fresh breeze ; and, as we passed on, amid sunshine and 
salutations, I forgot the purpose of my errand in the enjoyment of the glad scene around me.

But, unhappily for the continuance of these joyous feelings, the authorities had just secured a band of Sclavonian housebreakers, and, having bestowed upon them a very summary species of civil drum-head court-martial, had hung a dozen of them the previous day in the outskirts of the city. Of this uncomfortable fact we were entirely ignorant; and the shock may consequently be conceived when, on descending a steep pitch into the narrow street of Ortakeuy, the arabadjhe suddenly exclaimed-“ A man hanged! A man hanged! Hide your eyes, ladies." But it was too late. As the carriage turned the corner of the road I had caught sight of the suspended criminal, and I continued to gaze upon him, fascinated by the horror of the spectacle. This was only the second time that I had looked upon death, and it was now before me in so revolting a shape that I felt as though my lifeblood were curdling about my heart!

We had come upon the victim in so instantaneous a manner that the sleeve of my dress almost touched his arm, as he hung from the projecting spout of a house immediately beside our path. He was a tall, powerful man, bare-headed, and clad in a white jacket and trowsers, fastened about his waist with a scarlet shawl. But what made the exhibition tenfold more horrible was 
the fact that the rope had slipped during his dying struggles, and that his head was bent forcibly backward. I shall never forget it; and I verily believe that I should have remained without the power of turning away my eyes had not my companion aroused me forcibly from my lethargy; when, yielding to the heart-sickness which crept over me, I fortunately fainted, and thus escaped all further suffering from the disgusting spectacle.

I am not prepared to deny that these wayside executions may be very efficacious in preventing the spread of crime; it is a subject on which I am not competent to offer an opinion; but I am enabled from my own painful experience to decide upon their extreme inconvenience, to use no stronger term, to those who do not require so frightful a warning. To encounter death in a shape of violence upon the very path of the living, and in the midst of men busied in their daily avocations - to know that the narrow space in which the victim is suspended, surrounded by objects of barter, has been let out on hire for this horrible purpose - that a bargain has been made between the governinent and the shopkeeper for the use of the doorway leading into his dwelling - there is altogether something so revolting in the whole system that I cannot think of it without a shudder; and thus was every avenue into Pera closed 
for three days against those to whom such sights were painful; for the same ghastly object presented itself at each village leading from the city: while the body of the ringleader of the band, decapitated, and deprived of its right hand, was exposed in one of the public squares.

One of the gang saved himself by becoming at one and the same time a True Believer and King's Evidence ; the only individual of the association who would consent to accept life on such terms. The remainder, kept in ignorance, according to the Turkish custom, of the precise moment of their execution, were allowed to frequent the taverns and coffec-houses accompanied by a guard, during several hours, and to drink and converse freely with those whom they happened to meet there; when suddenly their career of intemperance was checked; they were halted in front of the house which had been fixed upon for their reception, the fatal noose affixed, a basket placed beneath their feet to be subsequently drawn away, and in another instant they were launched into Eternity, while the accents of revelry were yet upon their lips! $A$ s the Turks do not admit the efficacy of a tardy and terror-wrung repentance, they consider this mode of execution to be the most humane which they can adopt; and, as the criminal is flattered to the last with the hope of pardon, he thus escapes 
much of the premature suffering attendant upon a violent death.

In about an hour after we had escaped from the frightful spectacle I have described, we arrived at the gate of the Palace-an extensive and handsome edifice on the border of the Bosphorus; where a guard of soldiers and a throng of servants were to be traversed ere we could reach the staircase leading to the ante-room in which we waited, while our presence was announced to the princess. As Her Highness was in the bath when we entered, we were detained a considerable time in this apartment, surrounded by the officers of the household, and the principal negroes of the harem; a delay at which I rather rejoiced, as I had not altogether recovered from the effects of my morning's adventure.

At length we were requested to move forward, and, attended by half a dozen individuals of the Imperial suite, we traversed several apartments neatly matted, but quite destitute of furniture ; until at the extremity of a long gallery, lighted on either side by twelve spacious windows, commanding the channel on the one hand, and the palace gardens on the other, we reached the lofty doors of the harem, which were flung back at the first signal of our attendants, and as instantly closed again when we had crossed the threshold. 
A train of female slaves, dressed in the most gaudy furniture chintzes, received us as we entered, and led us across a lordly hall lined with white marble, and supported by numerous pillars of the same material; through whose open doors we had a delicious view of the extensive gardens, with their fantastic flower-beds, stately fountains, and gleaming terraces. Nazip Hanoum, the adopted daughter of the Princess, met us in the centre of the hall, and welcomed us most gracefully; after which, taking a hand of each, she conducted us to her own apartment, a charming room overlooking the water, and entered from a galleiy that surrounded the principal saloon. Having relieved us of our veils, and seated us on the cushions beside her, she clapped her hands, and about a score of slaves entered with coffee and sweetmeats.

The coup d'xil was beautiful, as the fair girls, not one of whom could have been more than twenty years of age, and who were all exceedingly lovely, prepared to hand the refreshments. The princess had given orders that we should be received with all possible ceremony: and the display was consequently most beautiful. One slave held a weighty vase, suspended from three silver chains, in which stood the coffee; another bore a large gold salver, covered with cups and holders of costly enamel, whence depended a dazzling drapery of gold 
tissue wrought with pearls, and richly fringed: a third carried a gilded tray bearing vases of cut crystal containing a variety of exquisite sweetmeats, confined beneath golden covers enriched with gems; a fourth held the salver on which stood a range of glass goblets of beautiful form and workmanship, filled with waterall, in fine, were laden with some object of cost and luxury; and their attitudes were so graceful, their faces so lovely, and their costume so striking, that I regretted their departure, when, after we had partaken of the rose-scented jelly and perfumed mocha, they slowly withdrew.

Nazip Hanoum, the favourite of Asmè Sultane, was purchased by Her Imperial Highness when she was only a few months old, together with her mother, who died while she was yet an infant. Her influence over the mind of her illustrious protectress is unlimited, and, had she been really born "beneath the purple," she could not have commanded greater liberty or consideration than she now enjoys. Her features are very regular, and even handsome; but her beauty is destroyed by the immense number of freckles that cover her face and bosom. Her eyes are a deep rich blue, with long dark lashes, and her hair is of a fine golden auburn; but the great charm of Nazip Hanoum exists in her extreme gracefulness; she has not a movement which is 
not elegant ; and her playful viracity and great natural shrewdness render her a delightful companion. Her voice is low, and sweet; and her ringing laughter the very echo of joyousness.

Her costume was an odd admixture of the European and the Oriental. She wore trowsers of pale blue cotton flowered with yellow; and an antery of light green striped with white, and edged with a fringe of pink floss silk; while her jacket, which was the production of a Parisian dress-maker, was of dove-coloured satin, thickly wadded, and furnished with a deep cape, and a pair of immense sleeves, fastened at the wrists with diamond studs. But the most striking feature of the costume in the Imperial Palaces is the head-dress. Nothing can be imagined more hideous! A painted handkerchief is bound tightly round the brow, and secured by jewelled bodkins: the back hair is crèpé until it becomes one huge dishevelled mass, when it is traversed across the top of the head by a corner of the handkerchief: a number of slender plaits of false hair hang down the back, frequently differing very materially from the colour of the natural tresses: the front locks are cut square across the forehead, and left a couple of inches longer at the sides, where they lie quite flat, and are stuck full of roses, or gems; or overhung by the deep fringe of the handkerchief, wrought to resemble a wreath of flowers. Some

vOL. 1 . 
few among the ladies of the Imperial Seraïs fasten immense bunches of artificial ringlets under their yashmacs when they drive out, but they are as yet sufficiently uncommon to be remarkable. To this head-dress, such as I have described it, Nazip Hanoum had added, in common with the other females of the household, a star and crescent of sticking-plaister between her eyebrows, which were stained a deep black, and destroyed the natural softness of her expression. But her hands and arms were lovely! White, and round, and soft, as though they had been moulded in wax; and her slight elastic figure looked as if it had been modelled by the Graces.

Asmè Sultane is celebrated throughout the capital for the beauty of her slaves; and his Sublime Highness has thrice demanded Nazip Hanoum, but has been thrice refused; an occurrence so unprecedented in the East, that he has finished by persuading himself that he is actually attached to the lively girl who has dared to play the part of a modern Roxalana, and to defy his power.

His first rejection was treated by the Sultan as the wayward whim of a spoiled beauty, and he even condescended to expostulate with Nazip Hanoum ; but his advice had no more effect upon her than his preference; and for the first time in his life, the "Brother of the Sun" and " Emperor" 
of the Earth" found himself slighted by a mere girl.

The cvil was, however, without remedy, for, as the adopted daughter of an Imperial Princess, the liberty of the young Hanoum was sacred; and his Sublime Highness was fain to content himself with the anticipation of future success; but, when a second solicitation brought with it only a second repulse, despite all the costly gifts and lover-like courtesies of the preceding twelve months, the enraged Sultan took up the affair in another tone, and accused the Princess of having instigated her favourite to this unheard-of rebellion against his sacred will.

The Sultana defended herself with all the energy of innocence, and even consented to fur: ther his suit by her counsels and persuasion, but no success followed her efforts. Nazip Hanoum preferred the partial liberty of the harem of her protectress, and the comparative independence of her present position, to the gilded captivity. of the Imperial Seraglio, and the fleeting favour of its lord; and she consequently continued firm.

The Sultan, enraged beyond endurance at this unexpected perseverance, left the palace in displeasure, and even refused to see his sister; whom he still persisted in believing to be the principal cause of his defeat. But monarchs are mere men where blighted feeling or wounded 
vanity make themselves felt: and Mahmoud, when he retreated to his gilded saloons at Beglierbey, shared the fate of his kind. He became convinced that he really loved Nazip Hanoum, and that her possession was necessary to his happiness; and, determined not to be thwarted a third time, he continued deaf to the earnest and humble prayers of the Princess that he would restore to her the light of his favour, and the glory of his presence; and actually refused during three long weeks to be accessible to her entreaties; when, feeling convinced that this display of his sublime wrath must have produced a powerful effect on the refractory beauty, he once more bent his course to the palace of the Princess.

A rich gift to Nazip Hanoum announced her pardon; and when she had played and sung, seated on a cushion at his feet, and he had witnessed the graceful movements of the dancing girls, and partaken of the perfumed sherbet of his Imperial Sister, he led the young beauty into the gardens of the palace, where she was compelled to listen for the third time to his thriftless suit. But, alas! for the lordly lover-the reflections of the past year had only strengthened her resolution, and she continued as unmoved by his protestations as she had been by his displeasure; and thus, Mahmoud returned once more to his Seraglio as unsuccessful as ever. 
Such is the sacredness of adoption among the 'Turks.

I have already mentioned that the Palace of Ortakeuy fronts the Bosphorus, from which it is only separated by a broad path or terrace of marble, extending along a considerable portion of the channel, and only broken at intervals by the projection of the different palaces and dwellings that are built against the edge of the stream. While we were conversing with Nazip Hanoum, my attention was attracted by a peculiar signal rising from this terrace, and evidently intended for the ear of some fair inhabitant of the Seraï. As no answer was returned, the shrill wild sound was repeated, when Nazip Hanoum rose quietly from her cushions, and throwing back a small door which opened in the midst of the lattice-work of one of the windows, demanded, in a tone of pretty peevishness, why she was thus persecuted, when she had announced her resolution not to receive another letter. 'The reply to this appeal, brief as it was, was conclusive, for, shrugging her shoulders with a coquettish gesture of impatience, she flung from the casement a painted handkerchief secured by a silken cord attached to the window-fiame, and after the delay of a moment, drew it back, and took a letter from amid its folds, which, having read with a blush and a smile, she thrust into the shawl that was bound about her waist, 
with all the composure of a person to whom such an occurrence was no novelty.

We shortly afterwards proceeded to wait upon all the principal ladies of the household, who occupied apartments opening from the same gallery as that of Nazip Hanoum. The first whom we visited was the mother of the slaves, a serious, stately woman, of about fifty years of age, dressed in an antery and trowsers of black cashmere, very silent, and even sad-looking, whom we quitted as soon as we had satisfied her curiosity; for the atmosphere of her stateliness did not appear congenial to our light-hearted conductress.

We were next introduced to Peroussè Hanoum, the private secretary of the Princess, who had been a favourite Odalique of Sultan Selim ; a woman remarkable for her talents both natural and acquired; and a celebrated poet. She was seated upon her sofa, surrounded by papers; lying confusedly in heaps, or tied up in squares of clear muslin; and engaged in writing on the lid of a chest inlaid with mother-of-pearl. She was still handsome, with delicate features, and fine eyes, but disfigured by the dye with which she had made her eyebrows meet across her nose. Had I been able to converse with her, without the interposition of a third person, I am sure that I should have been delighted, for she was all energy and enthusiasm. Her room was crowded 
with Turkish and Greek women, squatted on cushions all over the floor; and close beside her, with her pale cheek resting upon her knees, sat one of the laclies of the Imperial Seraglio, who having suffered severely from a protracted indisposition, had asked and obtained permission to spend a few weeks in the harem of the Princess, by whom she had been brought up. She was a lovely girl of eighteen or nineteen, very richly dressed, but evidently broken-hearted. Whenever she was addressed, the tears rushed into her large dark eyes, and every reply appeared to be an effort. 'The gilded Palace of her Imperial Master had evidently been a mere prison to her; and you read a tale of blighted hope and spirit-sickness upon every line of her pallid face.

While we were in the apartment of the secretary, Nazip Hanoum, at the request of the fair and faded visitor, sent a slave for her zebec, and played and sang with considerable sweetness and execution : after which the gifted Peroussè Hanoum read one of her poems, which elicited such rapturous applause, that I asked and obtained a transcript of it, and having caused it to be translated into French by one of the Professors of the Military College, I have since rendered it into English verse for the gratification of my readers.

We spent a considerable time in the apart- 
ment of Peroussè Hanoum ; and after having paid a number of less interesting visits, we finally entered the principal room of the Harem. Here we found a sweet girl of about thirteen years of age, lying upon a pile of cushions, having sprained her ancle a day or two previously, while dancing before the Sultan. She was amusing herself by nursing a very fine infant, a recent purchase of the Princess, who had bought both it and its mother, at the earnest request of the latter; who, having lost three husbands in the space of eighteen months, and being left entirely destitute, had profited by the well-known partiality of her Imperial Highness for children, to become an inmate of the Palace. The little girl was the pet and plaything, not only of Asmè Sultane, but of the whole harem; and was handed from one to the other, and caressed by all; while the mother did nothing but eat, sleep, and say her prayers; which latter ceremony she performed with most edifying ostentation.

What a bevy of fair girls occupied that apartment! What eyes, and lips, and teeth, were grouped together, as they sat clustered like bees upon their cushions, with their delicate fingers clasped together, and almost making their idleness look graceful! Here and there one lay fast asleep, with her cheek pillowed upon her hand, and a smile upon her lips, as though 
her last waking glance had been at the silver mounted mirror which lay beside her, and her last thought one of triumph at her young beauty.

A few were yet settling their cashemere girdles, and arranging their unwieldy head-dresses for the day, after their return from the bath; while one laughing maiden; who appeared to possess the talent in an extraordinary degree, was cutting court-plaister into various fantastic shapes, and dispensing them to her numerous applicants, by whom they were immediately affixed to their carefully-tinted eyebrows. The Kislar-Agha, meanwhile, walked in and out of the apartment, rolling the whites of his large eyes, and pouting his thick lips in silence, totally unmoved by the mirth and laughter going on in every direction; and scarcely replying to the questions and comments of those who were courageous enough to address him.

But, although there were many prettier women than herself in the party, Nazip Hanoum was the "Light of the Harem !" All gave way before her; her graceful playfulness, her joyous laughter, her innocent caprices, were alike received with smiles and approbation; and she appeared to be a general favourite, and to justify by her amiability the measureless affection of her Imperial patroness. We were shortly joined by 
Peroussè Hanoum, who accompanied one of the slaves on the zebec, while she sang, or rather recited, one of her own compositions ; after which the fair favourite played the theorbo, and, while another of the party beat the tambourine, half a dozen voices pealed out the ballads of the Sultan, who is also - a poet, and who frequently enjoys the happiness of listening to his own productions, from the lips of the fair household of his Imperial Sister.

The part taken in this concert by Nazip Hanoum and the Secretary was intended as a high compliment to their Frank visitors; for the Turkish ladies hold it as a degradation to exhibit a talent which is made an object of speculation and profit by hired performers.

Her Imperial Highness having left the bath with a violent and painful head-ache, we were requested to make a tour of the gardens, while she lay down to endeavour to obtain some relief: and accordingly, conducted by Nazip Hanoum, and followed by a dozen of her companions, we sallied forth by a door opening from the hall upon a stately terrace of white marble; and I laughed most heartily when, on emerging from the palace, the sprightly favourite shouted to the gardeners who were at work on all sides, "Do not look - we are coming out;" and, as a matter of course, every one of them turned towards her to utter their 
assurance of obedience, while away ran the laughing girl to gather the gayest flowers of the parterre, as an offering to the Frank ladies.

One fountain which we passed struck me as being peculiarly elegant; the stream, falling from an artificial eminence, filled successively eleven basins of white marble, gradually increasing in size, until the last formed a noble sheet of water immediately under the palace windows. The terraces were shaded by stately trees ; and a gaily gilded kiosk, superbly painted in fresco, throughout the whole of its interior, occupied the highest point of the grounds.

Having completed our survey of the gardens, and the Princess being still invisible, we proceeded, under the same guidance, to visit the state apartments, which were situated immediately over the harem.

The grand saloon, built above the marble hall, was the very embodiment of Eastern splendour. Its magnificently-painted dome was supported by forty porphyry pillars with gilt capitals ; its walls were lined with plate glass ; its doors veiled by silken draperies; its floor covered with Persian carpets; and the lattices which veiled the entrance to the women's apartments richly carved and gilt. At either extremity of the saloon, whose form was a fine oval, a noble flight of marble steps led downwards to the harem; and along the glittering balustrade 
were scattered groups of slaves, awaiting the summons of their Imperial Mistress, and clad in the gaudiest colours.

The morning-room of the Sultana was flooded with sunshine, and opened upon the terrace: the carpet, covering the floor, the cushions which were piled beneath the windows and the hangings of the walls, were all of the purest white, ornamented with wreaths of roses; while the roof, on which the Orientals universally display most elaborate taste, was of a deep purple colour, ribbed and studded with golden stars.

The reception-room was in a different style: sombre, magnificent, and almost cloistral in its decorations; heavy with gilding, and gloomy with cornices; while the sleeping chamber, hung with crimson and blue satin, and scattered over with perfumes and objects of taste, had an air of comfort and inhabitation almost English.

But the most elegant suite of rooms was that appropriated to the Sultan. A saloon whose thirty windows were hung with purple velvet fringed with gold; whose sofa cushions were formed of glittering tissue; and whose walls were rich with plate-glass and gilding; whose floor was crowded with objects of verti, and whose every table was scattered over with gems, opened into the Imperial sleeping-room, whose European bed, hung with flowered muslin, 
and decorated with knots of coloured ribbon, contrasted cheerfully with the heavy magnificence of the saloon and its elaborate draperies; while the mangal of wrought silver, richly gilt, and the collection of jewelled toys which filled the two recesses at the end of the apartment, brought back the imagination to the gorgeous East.

Incense-burners of gold, studded with precious stones; ring-trays wreathed with rubies; a miniature of the Sultan himself in a frame thickly set with diamonds, and resting upon a cushion of white satin; a toilette of fillagreed silver; a chocolate cup of enamel studded with pearls : and a gilt salver, covered with watches of all sizes and shapes, were part of the tempting array. But I was more delighted by a Koràn, and a manuscript collection of pravers, written by the Sultan, and splendidly illuminated. Both were bound in gold, with the Imperial cipher wrought upon each corner in brilliants, while a border was formed round the outer edges of the volumes, of passages from the holy writings, in different coloured jewels.

The private withdrawing-room was not remarkable in any respect, if, indeed, I except the circumstance of its sofa and curtains being trimmed with fluted gauze ribbon, which, to an European eye, produced a most extraordinary effect. But, upon the whole, I saw less inconsistency 
and bad taste exhibited in the arrangements of the numerous apartments that I traversed, than I had prepared myself to expect.

While we were making our tour of the palace, orders had been given by the Princess that the dancing girls should prepare themselves to exhibit their skill for our amusement; but, unfortunately, in the excess of her graciousness, she had resolved on treating us with a view of their new dresses and their new dances, both intended to be European; and assuredly such costumes were never before imagined. I will give the description of one-it will suffice to afford an idea of the whole. A dress of blue nuuslin, elaborately ornamented with bows of pink and scarlet ribbon, was drawn round the throat with a cord of green silk, which hung down the back and terminated in two heavy tassels; the petticoat was long and scanty, and was trimmed with two narrow flounces, edged with white satin; black leather shoes of the coarsest description, gloveless hands, a sash of pink and silver that swept the floor; a necklace of pearl ; and a head-dress at least a yard across, where a mass of false hair was smothered in flowers enough to decorate a supper table, and carefully selected of all the colours of the rainbow, completed the costume ; and I need not expatiate on its effect. But the admiration which it excited in the harem was immense; and the 
really beautiful girl who was the fortunate wearer of the motley garb appeared to consider herself raised above mortality, as she listened to the comments of the throng by whom she was surrounded.

The male dresses were in perfect keeping with that which I have endeavoured to describe; and the whole had found such favour in the eyes of the Sultana, that she only tolerated the Turkish costume on ordinary occasions.

As the day was waning to a close, and the distance to Pera was considerable, I was reluctantly obliged to decline the honour of dining in the palace, and awaiting until evening the appearance of the Princess, whose continued indisposition still confined her to her apartment; and accordingly, despite the remonstrances of our kind and courteous entertainers, I took my leave of the fair favourite and her talented friend ; bearing with me an invitation from Her Imperial Highness to repeat my visit at no distant period, when she might be able to receive and converse with me: and $I$ then returned to Pera with an aching head and dazzled eyes.

I subjoin the little ballad of Peroussè Hanoum, which I have rendered almost literally into English verse. I could have wished that it had been somewhat more Oriental in its character, but its quaintness is at least sufficiently characteristic. 


\section{BALLAD.}

My love for thee hath ta'en away my rest; By day and night I think of thee alone; I muse upon the curls which veil thy breast, And sigh to know that thou art not mine own.

My love for thee is madness! All esteem My passion folly who do look on me;

The arrows of thine eyes have drank the stream Of my fond heart; and I must part from thee.

My love for thee is deep; and I of late

Can look upon none other-Thou art cold, And 'tis the working of my hapless fate That I no more thy gracious smiles behold.

Leyla! be mine, and learn my spirit-wrong ; l'll tell thee all my grief-the tale is long. 


\section{CHAPTER XVIII.}

Kahaitchana-The Barbyses-The Valley of the Sweet Waters-Imperial Procession - National Interdict - Picturesque Scene - The Princess Salihè and her Infant - Forbearance of the Sultan - The Toxopholites-Imperial Monopoly-Passion of the Sultan for Archery -Record-Columns-The Odalique's Grave-The Lost One-Azmè Sultane-Imperial Courtesy-A Drive through the Valley.

The loveliest spot in the neighbourhood of Constantinople is undeniably Kahaitchana; called by the Franks the "Valley of the Sweet Waters," a name as appropriate as it is poetical.

The sparkling Barbyses takes its rise amid the rich vegetation of the valley, and traverses its greensward like a silver thread. As a river it is inconsiderable, but, being the only stream of any size within many miles of the capital, it is an object of great enjoyment and admiration.

The valley itself, like that of Rasselas, is shut in on all sides by tall and arid hills, amid which it nestles so fresh, and green, and sunny, that you feel at once that it was destined by nature for holyday uses. Need I say that the Sultan has here both a summer palace and a kiosk? There exists no pretty spot near Stamboul VOL. I. 
where he has them not; but the Palace of Kahaitchana is a favourite retreat, where he generally retires to escape from the coil and cares of the capital, whenever he can contrive to wring a day's leisure from the stern grasp of public duty. The ride from Pera is delightful: the air of the hills is so elastic that it seems to instil new life into your pulses; and the descent into the valley is so picturesque, that, despite your previous enjoyment, you are anxious to arrive in the lovely spot which lies, bathed in sunshine, at your feet.

A brighter day never shone from the heavens than that on which I joined a party who were bound for Kahaitchana. I had been indisposed for several days, and was too weak to indulge myself with a gallop; and accordingly, comfortably nestled amid the cushions of my araba, I suffered the more joyous and healthful of my friends to fly past me, and leisurely pursued my way to the valley.

As I descended the hill, I saw a procession of carriages issuing from the palace court, and making their way along the opposite bank of the stream, which forms the boundary of the Imperial pleasure grounds. A mounted guard stopped me for an instant at the foot of the height, but suffered me to pass after the delay of a moment, as he had received no orders to prevent the entrance of any Frank lady by that 
road; the interdict being confined to Greeks, Armenians, and Jewesses. Simply requesting me, therefore, to stop my carriage, as the Imperial family passed, he desired my arabajhe to proceed. I obeyed without hesitation; and, as the river is only a few feet in width, I had an excellent view of the distinguished party.

An open carriage, drawn by four fine bay horses, each led by a groom, contained the two younger sons of the Sultan, the palace dwarf, and the principal negro of the Sultan's household. The infant prince is a sweet-looking child, with bright eyes and rosy cheeks, and appears healthy enough to be the son of a peasant. Four bullock-carriages followed, and among their veiled occupants were the Princess Mihirmàh, her mother, and one of her sisters. Some of the younger ladies were exceedingly lovely, and wore their yashmacs so transparent, and so coquettishly arranged, that I could trace their features distinctly. This is, however, by no means the case generally speaking, as the inmates of the Imperial Seraglio are more closely covered when in a less retired spot, than any other of the Turkish women; and I remember on one occasion to have seen a favourite Odalique of the Sultan, who had a gauze auross her eyes, as well as wearing her yashmac close to their very lids !

Troops of negroes surrounded the carriages, 
and the procession was closed by the Kislar Agha, mounted on a superb Arabian horse, and accompanied by four attendants on foot.

As soon as the cortège had passed, I pursued my way, and found that my friends had been compelled to make a circuit, and to enter the valley by another road, which did not communicate with the palace grounds. Nothing could be more cheerful or more picturesque than the scene that met my eye as I descended from the araba. The greensward was covered with merry groups - Wallachian and Bulgarian musicians were scattered among the revellers; Bohemian flower girls were vending their pretty nosegays in every direction, so skilfully arranged that each veiled fair one saw in an instant whether the tale she wished to tell had been anticipated by the dark-eyed Floramounted patroles appeared and disappeared along the crests of the hills as they pursued their round of observation-an Imperial caĩque of white and gold was riding upon the ripple near one of the palace gates-Turkish servants were galloping in all directions-every avenue of the Imperial residence was doubly guardedand all was bustle and excitement.

As we were standing in front of the palace, two six-oared caïques drew up beside the terrace, and shortly afterwards appeared the Princess Salihè, the wife of Halil Pasha, at- 


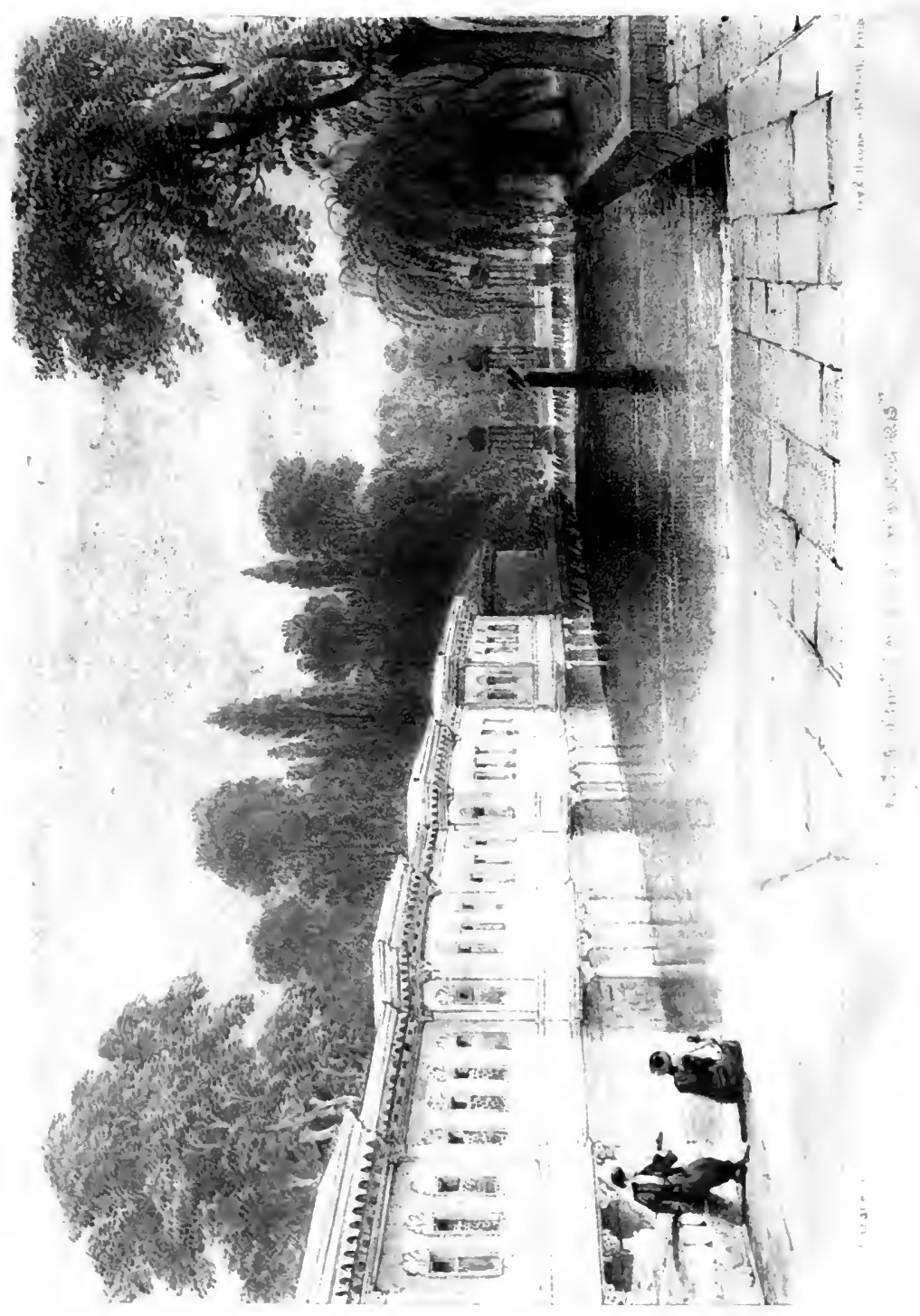


tended by half a dozen negroes, and twice as many female slaves, and followed by the head nurse carrying in her arms the lovely infant, on occasion of whose birth Sultan Mahmoud displayed such unprecedented generosity.

Heretofore, as it was stated at the time in the public prints, all the Emperors of Turkey had caused the male children of their own offspring to be destroyed, and thus provided most efficiently against future disputes relatively to the succession. The child on whom I now looked had not only been spared by its Imperial Grandsire, but public rejoicings had taken place on its birth-cannon had been fired, and ministers had been admitted to the Presence on audiences of congratulation. It was a noble boy, laughing and sporting in the arms of its nurse; and, as the caïques shot away, I busied myself with endeavouring to picture to my mind's eye the joy of the fond mother on learning that her child was to be spared to her. The delight was, however, fated to be transient, for Mahmoud was ere long released from his incipient enemy, (if such the little prince were indeed destined one day to become) without dyeing his own hands in blood. Three days after our visit to Kahaitchana he expired in convulsions, induced by his sufferings in teething.

As I understood that His Highness was engaged at archery with some of his favourite 
Pashas, I resolved on endeavouring to obtain a sight of him ; and accordingly one or two of our party detached themselves from the rest, and, making a circuit of the pleasure-grounds, we arrived opposite the spot where the Toxopholites were "speeding the winged arrow to the mark." A heavy cloud that was passing over the valley had already shed a few of those large drops which fall upon the leaves with the sound and the weight of hail; and the Sultan was seated beneath a red umbrella, held over his sacred person by one of the Officers of the Imperial Household. The favoured Pashas were standing in a line along the façade of the building; and a number of servants were dispersed over the lawn, for the purpose of collecting the arrows.

Apropos of umbrellas-Until the presentreign, the red umbrella was sacred to the use of the Sultan ; but his present Highness probably deeming the monopoly a very inconsequent one, graciously removed the interdict; and I need scarcely add that red umbrellas are now the rage at Constantinople.

Archery is a passion with Sultan Mahmoud, who is extremely vain of his prowess ; so much so indeed, that a long stretch of hilly country immediately in the rear of the Military College is dotted over with marble pillars fancifully carved, and carefully inscribed, erected on the 
spots where the arrows shot by himself from a terrace on the crest of the height are supposed to have fallen-I say supposed, for, as his foible is no secret, the Imperial pages who are employed to collect the shafts, and to measure the distances, generally pick up the arrow and run on twenty or thirty paces further, ere they affect to find it; by which means the Sultan shoots like the Prince Aimwell in the Fairy Tale; and the cunning varlets who restore his arrows earn many a backshish or present which more honest men would miss. I remember on one occasion, when on an exploring expedition, suddenly coming upon so handsome a marble column, inscribed with letters of gold, and surmounted by an urn, that I was curious to learn its purport; when, to my surprise, I discovered that this was a record-pillar of the same description; and as his Sublime Highness had on this occasion pulled a very long bow indeed, so he had perpetuated its memory by a handsomer erection than usual.

The archery party at Kahaitchana was amusing enough. First flew the arrow of the Sultan, and away ran the attendants; then each Pasha shot in his turn, taking especial care to keep within bounds, and not to out-('æesar Casar. Some of them looked important, and others horridly bored: but there was no escape from an amateur who boasts that he has practised every week for the last forty years. 
A little to the left of the spot occupied by the archers is a raised platform overshadowed by a weeping willow, beneath which rises a handsome head-stone. It is the grave of an Imperial Odalique, who died suddenly in the very zenith of her youth, her beauty, and her favour. She was buried in this lovely spot at the express command of the Sultan, who was so deeply affected by her loss that for two entire years he abandoned the valley. The platform is overlooked by the windows of the Salemliek, and every wind that sighs through the willow branches carries their voice to the ears of those who occupy its gilded chambers. Mahmoud, in a fit of poetical despair, is said to have written a pathetic ballad of which she was the subject. I endeavoured to procure it, but failed; and, as I was loath that she should remain unsung in Europe, I even tried my own hand in some wild stanzas, which I wrote hurriedly as I stood near her grave.

THE LOST ONE.

Spring is come back to us - the laughing Spring !

Sunlight is on the waters-

And many a bright, and many a beaming thing,

O'er this fair scene its gladdening spell will fling,

For the East's dark-eyed daughters.

But where is She, the loveliest of the throng,

The painter's model, and the theme of song; 
For whom the summer roses joyfully

Gave forth alike the beauty of their bloom,

Their dewy freshness, and their soft perfume :-

The loved of the World's Monarch-Where is She ?

Alas! for her the Spring returns in vain;

Her home is with the sleepers:-

She will not join in the glad song again

With which she once subdued the spirit-pain

Of the earth's pale-browed weepers.

For her the dance is ended-and for her

The flowers no more will their bright petals stir;

Nor the sad bulbul wake his melody :

The sunshine falls on every hillock's crest,

The pulse of joy beats high in every breast ;

But She, the loved and lost one, where is She?

She lies where lie the last year's faded flow'rs ;

She sleeps where sleep the proudest;

And there are eyes that will weep burning show'rs,

And there are sighs will wear away the hours

When the heart's grief is loudest.

Yet mourn her not, she had her day of pride,

The East's dread sovereign chose her for his bride;

The sunlight rested on her favour'd brow :

Like a fair blossom blighted in its bloom,

She filled an early, but a cherished tomb,

And where the mighty linger, rests She now !

Despite the sentiment of the thing, however, the beautiful Odalique has been long forgotten; and the bevy of beauties who wander near her grave have no time to sigh over her fate. It was, nevertheless, consolatory to my romance to 
remark that the Sultan shot his arrows in another direction!

On leaving the neighbourhood of the Toxopholites, I returned accompanied by a Greek lady to the araba, and drove higher up the valley; where we came in contact with the carriages of Azmè Sultane and her suite. On seeing us, she stopped, and, after inquiring if I were the Frank lady whom she had invited to her palace, she courteously and condescendingly expressed her regret that her indisposition had rendered her unable to receive me, but desired that I would hold myself engaged to spend another day in the Seraï ere long. She then, as a mark of especial favour, sent one of her negroes to the araba, with the infant to whom I have already made allusion, and whom I discovered to be the namesake of my lovely acquaintance, Heyminè Hanoum: the child was richly and fantastically dressed; and, when I had praised its beauty, admired its costume, and restored it to the attendant, I received a very gracious salutation from Her Highness, who moved on, followed by her suite.

The Princess, who is the widow of a Pasha, is a noble-looking woman, with a very aristocratic manner, and strongly resembles her brother. She has evidently been handsome, but must now be more than sixty years of age. Her fair favourite, Nazip Hanoum, was seated beside 
her, but so closely veiled, that, until she saluted me, I was unable to recognise her.

As we continued our drive, we passed a hundred groups of which an artist might have made as many studies. All was enjoyment and hilarity. Caïques came and went along the bright river; majestic trees stretched their long branches over the greensward; gay voices were on the wind; the cloud had passed away; and the sunlight lay bright upon the hill-tops. I know not a spot on earth where the long, sparkling summer day may be more deliciously spent than in the lovely Valley of the Sweet Waters. 


\section{CHAPTER XIX.}

Easter with the Greeks-Greek Church at Pera-Women's GalleryInterior of a Greek Church-The Sanctnary-The Screen-Throne of the Patriarch-The Holy Sepulchre-Singular $\Lambda$ ppearance of the Congregation - Sociability of the Ladies - L'Echelle des MortsShipping - Boats and Boatmen - Church of the Fanar - Ancient Screen - Treasure Chests - The Sanctuary-Private Chapels-A Pious Illumination - Priests' House-Prison - Remedy against Mahomedanism - Midnight Mass - Unexpected Greetings - The Patriarch - Logotheti - Russian Secretaries - Russian Supremacy in Turkey-Affinity of Religion between the Greeks and RussiansThe Homage-Pious Confusion-Patriarch's Palace-Lovely NightScene-Midnight Procession-Serious Impressions-Suffocating Heat -Dawn.

Our own Easter was over. The last dinner had been eaten, the last quadrille had been danced; politics had succeeded to parties, and diplomacy to dissipation; when the Greeks were preparing to celebrate the festival with all the poinp and circumstance of the most gorgeous and glowing of religions. I took this opportunity of paying my first visit to the Greek Chureh of Pera ; an elegant edifice built at the expense of the Russian government, and richly decorated with blue and gold; where the service is performed both in Greek and Russ, all the priests attached to it being Russians. 
A Greek lady, whose acquaintance I had made, politely offered me the use of her seat, which I accepted the more gladly, that without such accommodation I must have failed in my attempts to witness the ceremony; most of the females being obliged to content themselves with hearing the service, without a hope of seeing it. This difficulty arises from the fact that the women are not permitted to occupy the body of the church, but are confined to a gallery so closely latticed that it is impossible for those below to catch the faintest glimpse of the secluded fair-ones.

The appearance of a Greek church differs from those of the Roman Catholics, infinitely more than do the several religions. The Sanctuary, in the midst of which stands the High Altar, is separated from the church by a close screen; and there are neither aisles nor side chapels. The whole edifice is lighted by chandeliers suspended from the ceiling in three straight lines, reaching from the Sanctuary to the principal entrance: and the screen is ornamented with the effigies of saints, hardly and drily painted; which frequently figure in such sort in their temples as thoroughly to exonerate them from the imputation of making to themselves the "likeness of anything in Heaven, or on earth, or in the waters under the earth." Nor is this all ; for the pious being to the full as prone 
to make votive offerings to their favourite saints as any Catholic in Spain or Portugal, the staring, wooden pictures are furthermore decorated with gold and silver hands, eyes, ears, or noses, as the case may be ; which gives them so comical an effect that the gravest person cannot contemplate them without a smile.

The centre of the screen is closed by a curtain above the low double door opening into the church - the veil shrouding from the eyes of the congregation "the holy of holies," according to the old Jewish use. On the present occasion, the curtain was drawn back, and the High Priest was robing himself in front of the altar.

The Patriarch's throne was on the right hand, and immediately opposite to it was the pulpit; while at the bottom of the church on each side of the door stood two enormous chests of polished wood, containing the church plate and properties. In the centre of the marble floor was placed the boast and treasure of the chapel -a stone which once formed part of the Sepulchre of the Saviour, affirmed to have been brought from the Holy Land; and ultimately deposited here. The crush towards this point was enormous: the dense crowd shoving and elbowing each other most determinedly to secure an approach ; which, when they had effected it, enabled them to cross themselves, according to 
the rite of their church, seven times successively with a rapidity only to be acquired by long practice, and to kiss each extremity of the stone, leaving a piece of money in the salver of the attendant priest.

Huge wax candles of at least seven inches in diameter were burning in front of the Sanctuary, and on the canopy covering the Sepulchre; and the glare fell upon a dense crowd of heads, some shaven close, some decorated with a single long tress of hair hanging from the summit; some half-shaved, as though a platter had been adjusted to the cranium of the individual, and that the barber had operated round its edges ; and others with long dishevelled elf-locks falling about their shoulders-the effect was perfectly ludicrous!

Meanwhile, the ladies in the gallery were not idle: compliments were exchanged - inquiries made and answered-and conversations carried on, as coolly as though the interlocutors had been quietly seated in their own houses: while every five or six minutes a priest made his appearance, bearing a salver to receive the donations of the pious and charitable. But I soon wearied of the nasal, monotonous chant of the officiating priests, which more than counteracted the light and gladsome aspect of the edifice; and, satisfied with having seen a great deal of paint and gilding, and a rich display of tissue 
and embroidery, as well as a holy scuffle among the crowd at a particular period of the service, to possess themselves of the candles that had lit up the Sepulchre, I escaped from the scene of pious confusion; and slowly taking my way through the cypress-shaded burial-ground, and onward to the Echelle des morts, I gladly stepped into the caique, to share, bencath the hospitable roof of a friend, in the magnificent ceremonials which were to take place in the ancient patriarchal church at the Fanar.

As we traversed the port, I was struck by the various character of the shipping, more than usually conspicuous under a flood of bright sunshine. The vessels of war, (one of them the largest in the world) were lying like floating cities on the still surface of the mirror-like Bosphorus: the foreign merchant ships, anchored in dense ranks along the shore, with their sails furled, and their slender masts shooting upwards, like the tall stems of a wind-stripped forest-the Arab vessels, with their sharp high prows and sterns, precisely as I had often seen them represented on the antique medals-the steam-packets, dark and motionless like oceanmonsters, about to vomit forth their volumes of thick, suffocating smoke upon the clear air; while about, and around, and among all these, darted, and glided, and whirled, the slender caïques of polished and carved walnut wood, 
with their gracefully-clad rowers, and their minute gilded ornaments glittering in the light; the sharp shrill cry of "On the European side""On the Asiatic side!"-ringing upon the ear every moment, as the boatmen indicated each to the other which course to steer, in order to leave to all a free passage.

We landed on a terrace overhanging the water, at the extremity of our friend's garden ; and after taking coffee with the ladies, immediately set forth to visit the church by day-light. Though more limited in its dimensions, and less rich in its decorations, than the church at Pera, it nevertheless pleased me infinitely better; there was an air of time-hallowed holiness about the whole of its interior, far more attractive than the unfaded paint and fresh gilding which I had seen in the morning.

The Patriarch's throne, simple, and even clumsy in its form and fashion, had existed for twelve hundred years, and was consequently respectable from its antiquity; close beside it stood the raised and high-backed chair of Logotheti ; and about twenty feet beyond, stretched the magnificent screen of the Sanctuary, delicately carved in dark oak. This screen particularly attracted me, the workmanship was so minute and elaborate, and the columns which separated the panels in such high and bold relief. Here, as at Pera, dry, hard, savage-looking VOL. I. 
Saints ornamented the spaces between them, and were equally decorated with the incongruous and disjointed offerings of their votaries.

The most popular personage of the whole calendar among the Greeks is decidedly St. George, who had no less than two entire effigies in beaten silver in this church. The pulpit was of mosaic, thickly overstrown with stars of mother-of-pearl; and two large chests, similar to those which I have already named, were composed of the same materials. The women's gallery was even more closely latticed than that at Pera, and the flood of light without was admitted so sparingly by the high and infrequent casements, that a solemn twilight reigned throughout the edifice, which accorded admirably with its antique and somewhat gloomy character.

Thanks to the guidance under which we entered, the priest who had opened the doors for us was obliging enough to walk to the other extremity of the church, and thus leave us the opportunity of penetrating into the Sanctuary, which the profane foot of woman is supposed never to tread. It consisted of a small chapel, containing an altar by no means remarkable, spread with the sacramental plate: a highbacked chair of marble for the Patriarch, a fountain for the use of the officiating priests, a few miserable oil-paintings, and a vast number 
of small pictures of Saints and Virgins, placed there during a certain time for " a consideration," to become hallowed by the sanctity of the spot ere they were removed to the private chapels of the different families : every Greek, however limited in fortune, having an apartment in his house fitted up as an oratory.

I was, however, much more amused (for that is the only applicable word) in watching the proceedings of a Greek lady who had accompanied me, than in contemplating the portly saints and florid martyrs by whom I was surrounded. A slight iron rail runs along the screen at the base of the paintings for the purpose of supporting the tapers which the zeal of the pious may be inclined to burn in their honour ; and my companion was busily employed in lighting a score of these minute candles at a lamp that is constantly left burning for the purpose; humming in an under-tone, while she did so, the barcarolle in Masaniello which was exchanged, as she commenced her survey of the holy group, for such exclamations as the following:-

"The Virgin - I shall give her four, because my own name is Mary - and look, I pray you, at the pretty effect of her gold hand, and her silver crown, with the light flashing on them. Now comes St. George - I like St. George, so he shall have two. Who is this? Oh! St. 
Nicholas ; I cannot bear St. Nicholas, so I shall pass him by."

I ventured to intercede in his favour.

"Very well, then, as you wish it, there is one for him ; but he never was a favourite of mine: there are two saints in the calendar to whom I never burn a taper, St. Nicholas and St. Demetrius."

It was, however, finally settled that no partialities were to be indulged on the present occasion, and consequently the effect produced was that of a miniature illumination. My curiosity being satisfied, and the pious offering of my companion completed, we proceeded to make a tour of the vast monastic-looking building forming one side of the enclosurc, and which is appropriated to the priests. Ascending an external flight of steps, we found ourselves in a wide gallery, whence the apartments opened on the right and left, precisely as the cells are arranged in a convent. One of these small, but comfortable, rooms is allotted to each individual; and those which we visited were very carefully carpeted and curtained, with divans of chintz, and every luxury customary in Greek apartments. In many of them we found ladies taking coffee with their owners, while servants were hurrying to and fro, full of bustle and importance.

Altogether there was an atmosphere of comfort about the establishment, which quite made 
me overlook its otherwise dreary extent; and as I passed out by another door, having before me the Palace of the Patriarch, I felt no inclination to commiserate the worldly condition of his subordinates.

From the Priest's House we proceeded to the prison,* where we found one miserable urchin of twelve years old, "in durance vile" for an attempt to turn Musselmaun; he was ragged and almost barefooted, and some pious Turk had promised to recompense his apostacy with a new suit, and a pair of shoes; but, unfortunately for the cause of the Prophet, the boy was caught in the act of elusion, and delivered up by his exasperated parents to the authority of the Church, which had already kept him a prisoner for eight days, and was about to send him, with a chain about his leg, to spend a month in a public mad-house!

What analogy the good Papas had found between the mosque and the mad-house I know not; but the punishment was certainly a most original and frightful one. The boy told us his own tale, and then added, with a broad grin, that he would take them in at last. Two other prisoners, accused of theft, were about to suffer their sentence in a day or two: exile in both

- The fact of the Patriarch being not only the liearl of the church, lut also the chief magistrate of his nation, will account for the proximity of the prison to the Episcopal l'alace. 
cases, accompanied by branding on the breast in the most aggravated of the two; and, meanwhile, close confinement. They were a couple of shrewd-looking, desperate ruffians, and laughed in his face as the keeper spoke of them. We were then shown the bastinado, and the rings and chains for insubordinate prisoners; and, after having made a donation which was received with a surprise perfectly untrammelled with gratitude, I returned to the residence of our hospitable friends, with the rattling of fetters in my ears, and a thousand gloomy fancies floating over my brain.

At half past ten o'clock we repaired once more to the Church, in order to assist at the midnight mass; where a Greek lady very politely gave up her seat to me, that I might have an uninterrupted view of the ceremonies. The service had already commenced when we entered, and the whole interior of the edifice was one blaze of light. The thirty chandeliers suspended from the ceiling threw a many-coloured gleam on the crowd beneath them, from their pendants of tinted glass ; and the huge candles in front of the Sanctuary, and the tapers burning before the saints, added to the brightness of the glare; which, penetrating through the lattices of the gallery, enabled me to contemplate as extraordinary a scene as I had ever witnessed in a place of worship. The fair tenants of the front 
seats presented much the same appearance as a parterre of flowers; there were turbans of every tint, dresses of every dye, bonnets of every form : and such a constant flutter, fidget, and fuss ; such bowing, smiling, and whispering, that I began to fancy there must be some mistake, and that we were, in fact, gathered together to witness some mere worldly exhibition.

But the monotonous chanting of the priests, which had been momentarily suspended, was. suddenly renewed; and I turned away from a score of polite greetings, offered by persons of whom I had not the slightest recollection, but to whom I had doubtlessly been presented during the carnival, in order to observe the proceedings bencath me.

The Patriarch was seated on his throne, dressed in a vestment of white satin, clasped on the breast with an immense diamond ornament, over which was flung a scarf of gold tissue; the borders of the robe were wrought to about a foot in depth with portraits of the saints in needle-work of different colours, interspersed with gold and silver threads. His crown of crimson velvet was entirely covered with immense pearls, fashioned into different figures; the intermediate spaces being occupied by rubics, emeralds, and brilliants, of great beauty and lustre. He held his staff in one hand, and in the other the Gospel, bound in white satin, and 
studded with jewels; and, at every movement that he made, the tapers by which he was surrounded flashed back the radiance of his elaborately-gemmed habit in a coruscation perfectly dazzling.

Beside him, and on a level with the throne, sat Logotheti, in an uniform richly embroidered with silver; my father was beside him; and at the foot of his chair stood Vogorede; while immediately in front of the throne, in a line with the pulpit, four of the Russian Secretaries occupied a crimson-cushioned seat, whence they had a full view of the Sanctuary.

Among the numerous causes, all working towards the same centre of Russian supremacy in Turkey, one of the most dangerous for the Moslem is the community of religion between the Russian and the Greek. The Autocrat has built a church for the Greeks in the vicinity of Constantinople, and the arms of Russia surmount the portal! The attachés of the Russian Embassy, while the members of all the other Legations are either sleeping or feasting, are meekly kneeling before the throne of the Greek Patriarch, and humbly kissing the hand which extended to them!

The act in itself is simple. It is the effect that it produces on the minds of the mass which is to be dreaded. The expression of delighted admiration on the countenances of the 
crowd was a perfect study, as, following in the wake of Logotheti and Vogoride, ere less important persons had an opportunity of doing homage to the Patriarch, the all-powerful agents of all-powerful Russia bent a willing knee to kiss the sacred hand. A common interest was created at once, and no tie is so sure as that of religious faith. The Greeks already writhe in their fetters-the bondmen loathe their taskmasters - the tree is cankered at the core, and hollowed in the trunk : let Russia apply the axe, and it will fall.

The Moslem, be he lured to ruin as smilingly as he may, and flattered into security as blandly as the criminal of his country, who finds the rope about his neck ere he knows that he is condemned; is the coveted prey of his semibarbarous ally. The force of the Russian, and the guile of the Greek-external power and internal treachery-are at work against him; and what has he to oppose to these? High-sounding titles, and pompous phrases - a young and half-trained soldiery - a navy, unequal to the management of their magnificent shipping and a Capital, protected by men, many of whom wear a Russian medal at their breast-a medal bestowed on them by the munificent Emperor of another nation, for having done their duty (according to Muscovite notions) towards their own! 
But let 'Turkey be supported for awhile, as her own efforts merit that she should be ; let her find the ready help from European powers, in which she so fondly trusted - and she will, ere long, prove herself worthy to take her place among the nations. Her military and naval forces require only time; her soldiers have already given evidence of their courage, and, having so done when comparatively undisciplined, will naturally develop still higher attributes when acting as a well-organized body; in which each individual receives, as well as gives, support. Let the Russian medal be trampled in the dust of the city streets - and this will demand no effort on the part of those who wear it, into whose breasts it burns, and who consider it rather as a brand of disgrace, than as a creditable badge-and it will then require no spirit of prophecy to foretell the future prosperity of Turkey. To the East, Europe is indebted for her knowledge of military tactics and military subordination, and she can well afford to pay back the debt. Half a dozen experienced officers would, in a few months, change the whole appearance and nature of the Turkish army.

Homage had been paid to the Patriarch, and the chanting became more animated, as, followed by a train of Archbishops and Bishops, he retired to the sanctuary, and added to his 
already costly habiliments several other jewelled and enbroidered draperies. He next received the sacrament, at which period of the ceremony every man, woman, and child, within the church hastened to light the taper that they had brought for the purpose, (the symbol of the Resurrection) which produced a sudden burst of light absolutely thrilling. As I looked down upon the struggling and stifling crowd beneath me, so closely wedged together that it was with difficulty they could raise the arm holding the taper, which each lit by that of his neighbour, the scene was most extraordinary. A dense vapour was even then rapidly spreading its heavy folds over the whole edifice, and, in a few moments, I could distinguish nothing but a sea of heads, and a multitude of pigmy lights, feebly struggling through the thick smoke.

The fiery and impetuous Greeks, enthusiastic in all their feelings-in religion, in love, in hate, and in ambition-did not, in the present instance, confine themselves so scrupulously as an European congregation would have done, to the space assigned to them-half a dozen wild, bandit-looking individuals clambered into the pulpit-a score more clung to the steps-those who chanced to be nearest to the racated stalls of the Bishops appropriated them without ceremony - others hung by the pillars which supported the gallery-and thus sufficient space was 
with difficulty ensured by the panting beadles for the passage of the procession.

At this moment, I followed my friend from the church, and, four or five sturdy servants having with considerable effort forced a way for us to the Patriarch's Palace, we hastened to take possession of his private sitting - room, which, as it overlooked the enclosure in which the church was situated, and where the procession was to halt, he had politely offered, in order to secure the gratification of my curiosity.

'The night was one of beauty. The pale moon was riding high among masses of fleecy clouds, which were pillowed upon the deep blue of the sky, forming towers, and palaces, and islets, so changeful and fleeting, that they looked like the ephemeral creations of fairy-land. A lofty and leafy plane tree, whose foliage had newly burst beneath the soft influcnce of spring, was sighing gently in the midnight wind; and the long dark outline of the monastic buildings, and the slanting roof of the church, loomed out in the faint moonlight, with a mysterious depth of shadow well suited to the solemnity of the hour. The wide doors of the saered edifice suddenly fell back - the low chant of the choir swelled upon the night air-and forth rushed the eager crowd that had so lately thronged the church; each with his lighted taper in his hand, and pressing forward to a raised platform in the 
centre of the enclosure, railed in for the convenience of the Patriarch and his train of dignitaries.

Ere long, the whole of the wide space was like a sea, in which the dark waves flung themselves upwards in fiery sparks, while they rolled and swelled in gloom beneath the surface-or like a spot upon a sky of tempest, into which were gathered all the stars of heaven to form one galaxy of light amid the surrounding gloom. And forth into this place of brightness slowly moved the holy train from the chapel. First came the bearer of the golden crucifix, surrounded by gilded lanterns and gleaming candlesticks; and next the torch-bearers, whose waxen candles, linked together in threes with gaudilycoloured ribbons, represented the Trinity; then moved forward a train of priests, walking two and two, with their flowing robes of saffroncoloured satin, their luxuriant beards sweeping down to their breasts, their brimless caps, and their long locks falling upon their shoulders.

Nothing can be more picturesque than the head-dress of a Greek priest. As they are not permitted to use either scissors or razor from the period of their birth, when they are vowed to the Church by their parents, they reduce the beard by plucking it, according to the old Jewish law ; and, being almost universally very fine men, they do this with a care and skill 
which heighten the effect of their appearance; while their long thick locks are, on ordinary occasions, hidden beneath their caps.

This holy body was succeeded by the Patriarch, supported on either side by two of the Archbishops, who, in the Greek Church, represent the Apostles, as the Patriarch himself personates the Saviour, and followed by the ten others in robes of such dazzling brilliancy that any attempt at description would be idle. Immediately after these came the Bishops, walking two and two; succeeded in their turn by Logotheti and Vogoride, another train of priests, and finally by that portion of the congregation who had not been able to effect an earlier egress from the church.

The junior priests arranged themselves in a circle at the foot of the platform, which was soon filled by the heads of the Church, and the lay dignitaries, among whom stood my father. The Patriarch read a portion of the scriptures, from an ample volume that lay open on the stand before him: the attendant priests chanted a psalm which rose and fell on the night wind in solemn cadences; and, finally, the elder of the Bishops, having placed in the hand of the Patriarch one of the triple candles which $I$ have already named, wherewith to bless the people; and subsequently two linked together, representing the double nature of Christ; the whole 
crowd bowed their uncovered heads, and erossed themselves seven times, with the collected points of the two fore-fingers and the thumb; after which a passage was with difficulty forced through the crowd for the return of the procession, whose chant gradually died away upon the ear, as it disappeared beneath the portal of the church, and in five minutes more we were alone, gazing out upon the empty enclosure flickered with moonlight.

It was a solemn moment! The pomp and circumstance of human worship had passed away, and we looked only on the uncertain moon, over which the light scud was rapidly drifting; while the only sound that fell upon our ears was the sighing of the midnight wind through the leaves of the tall plane tree. I bowed my head in silence upon the cushion against which I leaned - my excited fancies were suddenly sobered, my throbbing pulses stilled - Nature had spoken to my heart, and my spirit was subdued beneath her influence. It was a sudden and strange reaction; and, could $I$ at that noment have eseaped to the solitude of my own chamber, I do not think that one idle memory of the magnificence which I had so lately witnessed would have intruded on my reveries.

Man's pride, and pomp, and power, had fettered my fancy, and riveted my gaze-But it was night; the still, soft night, with its pale 
moon, its mysterious clouds, and its sighing: voice, which had touched my spirit. In such hours, the heart would be alone with Gop!

When we re-entered the church, I feared that I should have fainted; thick volumes of smoke were rolling heavily along the roof ; the suffocating incense was mounting in columns from the censers - the myriad tapers were adding their heat to that of the burning perfume; and the transition from the light pure atmosphere without was sickening. I persisted, nevertheless, in my determination of remaining until the close of the ceremony, which concluded with the Declaration of. Faith, read by Logotheti ; and a portion of the Gospel, delivered from the pulpit by a priest, richly dressed in blue and silver.

The grey light of morning was glimmering on the Bosphorus as we returned to the house, where we breakfasted, and then retired to bed with aching heads and dazzled eyes, to prepare for the fatigues of the morrow. 


\section{CHAP'TER XX.}

Feasting after Fasting-Visit to the Patriarch-Gorgeous ProcessionInconvenient Enthusiasm-Indisposition of the Patriarch-The Ceremony of Uurobing-The Impromptu Fair-The Patriarch at Home -The Golden Eggs.

To what a breakfast did we sit down the following morning! The long and rigorous fast was over, and a hearty vengeance was to be taken for the previous forty days of penance and abstinence. It was amusing to remark with what interest every dish was examined, and how universally each was rejected which was not composed of some hitherto forbidden luxury. The centre of the table was occupied by a porcelain bowl filled with eggs boiled hard, and stained a fine red with logwood; but it was placed there merely in compliance with the national custom, as an Easter emblem; for on this, the first day of emancipation from the thrall of fast, no individual of the party had a thought to bestow on such primitive fare.

At the conclusion of the meal, I went, accompanied by my father, and a fine youth who had escaped from college for the Easter recess, and

vol. I.

$\Lambda \Lambda$ 
who volunteered to act as interpreter, to pay a visit to the Patriarch, who had expressed a desire to make our acquaintance. We were conducted through several large, cold, scantily furnished apartments, presenting rather the appearance of belonging to a barrack than to an episcopal palace, with their floors thickly strown with bay leaves, which emitted a delicious perfume as we passed along, to the private sitting-room overlooking the court of the church, where we seated ourselves to await the arrival of the Patriarch, who had not yet left the Sanctuary.

A sudden rush from the door of the church called us to the windows, whence we could distinguish, in the distance, the gorgeous procession which was conducting the Patriarch home after eight and forty hours of constant ceremonial. We had ample time to enjoy the spectacle, for the throng was so dense, that it was with the utmost difficulty that the beadles and kavasses could force a passage through the excited and clamorous multitude, for the objects of their overweening and inconvenient enthusiasm. Nor was the difficulty likely to decrease, for the crowd were still pouring out from the church, clinging one to the other to secure their footing, and defying alike the many-thonged whips of the beadles, and the powerful elbows and staves of the police. 
The Patriarch, who had rigorously observed the fast throughout the whole of Lent; and who had, moreover, only partially recovered from a severe and lingering illness, was little able, after forty-eight consecutive hours of exertion, to contend with this unlooked-for and gratuitous demand upon his energies; and as he moved forward, supported by two of the Bishops, he continually implored the forbearance of the people, who, in their eagerness to kiss the hem of his garment, subjected him to no slight risk of suffocation. But he implored in vain; the crowd shouted and struggled - the beadles struck and shoved - and the priests threatened and expostulated-unheeded; while the Patriarch was ultimately lifted from his feet, and carried to the foot of the great stair leading to the palace, by half a dozen of his followers.

The solemn chant of the approaching priests instantly re-echoed through the vast pile, and an avenue was formed from the portal of the building to the door of the apartment in which we stood. First entered the incense-bearer. who swung his censor twice or thrice at each extremity of the room, and then hastily withdrew; and he was almost immediately followed by the whole train of Bishops, sinking under the weight of jewels and embroidery in which they were attired, and who took their places in line along the edge of the divan, and there awaited in 
silence the arrival of the two Archbishops who preceded the Patriarch. 'The sight was dazzling! on all sides a mass of gold and precious stones, of tissue and embroidery, presented itself ; and the eye actually ached with gazing. After the lapse of a few seconds, the Great Dignitaries also arrived: and as I advanced to kiss the hand of the Patriarch, I felt completely overawed by the magnificence of the spectacle.

The ceremony of unrobing followed, during which the solemn chanting of the priests, who lined the gallery through which the train had passed, was never once interrupted; and as the Bishops cast off robe after robe of costly silk, gorgeous brocade, and glittering tissue, I only marvelled how they could have supported such a weight of dress amid the crowd that had so unmercifully pressed upon them below, without sinking under it!

A furred mantle having been flung over the shoulders of the Patriarch, he was conducted from the apartment, followed by the Bishops; and we remained for a time watching the movements of the multitude in the court beneath, while he prepared himself to receive the numerous visits which he had to undergo, ere he could enjoy the repose that he so much needed. Triumphal arches, formed of green boughs and flowering shrubs, had been hastily set up in every direction, and beneath these stood the 
sherbet venders, and confectioners, without whom no festival is complete in the East.

The church doors were already closed: and the versatile Greeks were now as ardent and eager in the pursuit of pleasure as they had been but an hour previously in that of salvation. Most of them were employed in re-arranging their turbans, which had been unwound in the late struggle; others were squatted on the ground, eating yahourt (a sort of coagulated buttermilk) out of small earthen basins, which they emptied with their forefinger, with a rapidity perfectly surprising; and others again surrounding a molalibè merchant, whose large tray, neatly covered with a white cloth, china saucers, and shining brass spoons shaped like trowels, enhanced the relish of the dainty that he dispensed-a species of inferior blanc-manger, eaten with rose-water and powdered sugar.

A servant having announced that the Patriarch awaited us in another department, we followed him to a spacious saloon in the opposite wing of the palace, where we found the magnificent Prelate seated in a cushioned chair raised a few steps from the floor. He had exchanged his party-coloured raiment for a flowing robe of violet silk with a falling collar of velvet, and wore about his neck a massive gold chain, from which was suspended a star of brilliants. On his right hand were two baskets of variegated 
wicker-work ; the one containing eggs of a crimson colour richly gilt, and the other filled with eggs of white and gold; while on his left-hand, a larger basket was upheaped with others simply stained with logwood, like those which I had seen on the breakfast table.

He received us with much politeness; and, through the medium of our young friend, who made an admirable Dragoman, he asked me several questions on the impressions which I had received in the East: appeared gratified at the admiration that I expressed of the gorgeous ceremonial to which I had so lately been a witness; and regretted that the exhaustion under which he was then suffering from the fatigues of the last two days rendered him unable to converse with me, as he had been desirous of doing.

Coffee and sweetmeats were shortly afterwards served; and, as I was aware that the anti-room was thronged with persons who were waiting to pay their compliments to him, I rose to depart; when he presented to me a couple of the gilded eggs, which he accompanied by a flattering expression of the pleasure that my visit had afforded to him, and a hope that he should again see me when his health was re-established. I made as handsome a reply as I was capable of doing; pressed to my lips the holy fingers which were extended towards me, and took my leave.

I was not aware, as I received the eggs, of the 
extent of the compliment that had been paid to me, which I only learnt accidentally, on inquiring the origin and meaning of so singular an offering. The custom, as I was informed, is of so ancient a date, that no reason, save its antiquity, can now be adduced for its observance; but great ceremony is kept up in the distribution. To the principal persons of the nation the Patriarch gives two of those eggs which are gilt, to the next in rank one gilt and one plain-then follows one gilt-then two plain-and finally one -but, to each person who is admitted to the presence of the Patriarch, he is under the necessity of making the offering, be the guest who he may; and a day is set apart during the week, on which the whole of the male Greek population of Constantinople have the right to receive it at his hands, until extreme fatigue obliges him to resign the office to the GrandVicar.

On returning to the house of our friends, we partook of coffee, and the delicious Easter cake peculiar to the Greeks ; and immediately afterwards embarked in our caïque, which was to convey us to the Echelles des Morts, in order to witness the festivities of the Armenians in the great cemetery. 


\section{CHAPTER XXI.}

High Street of Pera-Dangers and Donkeys-Travelling in an Araba -Fondness of the Orientals for their Cemeteries-Singular Spectacle -Moral Supineness of the Armenians-M. Nubar-The Fair-Armenian Dance - Anti-Fxclusives - Water Venders - Being à la Franka-Wrestling Rings-The Battle of the Sects.

The araba was already at the door when we arrived at home; and, weary with mounting the steep ascent to Pera, I gladly threw myself upon the crimson mattress, and among the yielding cushions, and prepared to become a spectator of this new festival in luxurious inaction.

Let no one venture either on foot, on horseback, or in a carriage, along the all-but-interminable High Street of Pera, on a fête-day, if he be in a hurry! In the first place, two moderately-sized individuals who chance to be opposite neighbours may shake hands from their own doors without moving an inch forward-and in the next, there is no other road from Topp-hannè or Galata (the principal landing-places) to the Great Cemetery. And then the natives of the East have a very sociable, but extremely inconvenient habit of walking with their arms about each other's necks, or holding hands like children 
in parties of five or six, although they are obliged, from the narrowness of the thoroughfare, to move along sideways; but, nevertheless, they will not slacken their hold until the necessity for so doing becomes sufficiently imperative to admit no alternative.

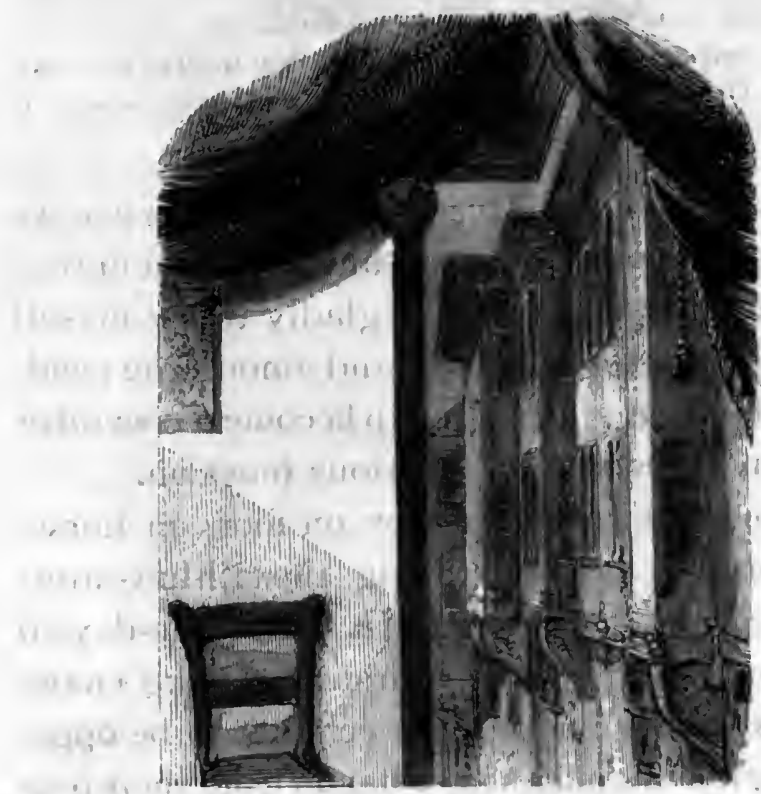

A STREVT IN PERA.

Another peculiarity attending an Eastern mob is its utter disregard of being run over, or knocked down : an Oriental will see your horse's nose resting on his shoulder, and even then he will not move out of the way until you compel him; and when your arabajhe warns him that he is almost under the wheel of the carriage, he 
looks at him as though he wondered at the wanton waste of words bestowed upon so insignificant a piece of information.

But, if the bipeds are difficult of management, the quadrupeds are altogether unmanageable! Let those whose nerves are shattered by the rattle of the London carts come here, and have their temper tried by the donkeys of Constantinople. You have scarcely turned the corner of the street, and forced your way among the clinging, chattering, lounging mob, ere you come upon a gang of donkeys-your horse is restless, he champs the bit, paws with his foreleg, and backs among the crowd, in his impatience to get on; you must be contented to allow him the privilege of champing, pawing, and backing, for there is no contending against a string of a dozen donkeys, laden with tiles.

While you are trying to look amused at your dilemma, and endeavouring with "favour and fair words" to induce their owner to arrange them in regular line in order to enable you to pass, you hear a portentous clatter a hundred yards a-head:-you look forward with foreboding, and your fears have not misled you : it is, indeed, " the meeting of the donkeys ;" and another gang, heavily charged with earth, or bricks, or unhewn stone, are gravely approaching to entangle themselves among your first favourites, and to be dislodged only with blows 
and kicks very ill-calculated to pacify either you or your horse.

In an araba your case is still more hopeless; for a horse must get on at last, by dint of intruding upon the pavement, and impudently poking his nose into every window ; applying his shoulder to the back of one individual, and whisking his long tail into the face of another-but a carriage following a carriage must be satisfied to travel at the pace which may chance to be agreeable to its leader-while a carriage meeting a carriage is pushed one way, lifted another, driven against the walls of the houses, and shoved into the kennel, until you begin to consider it very doubtful whether you possess sufficient strength of wrist and tenacity of finger, to enable you to remain within, while such violent proceedings are taking place without. And when to these difficulties are superadded the inconvenience of a dense, reckless, pleasureseeking mob, it must be conceded on all hands that the progress along the High Street of Pera on a festival day is by no means " easy travelling."

On the occasion of which I am about to speak we encountered three detachments of donkeys, four arabas, six horses laden with timber, and a flock of sheep-fortunately, we were by no means pressed for time; though how we escaped victimizing a few of the supine subjects of his Sublime Highness, I cannot take upon me to explain. 
I have already spoken elsewhere of the indifference, if not absolute enjoyment, with which the inhabitants of the East frequent their burying-grounds ; but on the occasion of this festival I was more impressed than ever by the extent to which it is carried. The whole of the Christian Cemetery had assumed the appearance of a fair-nor was this all, for the very tombs of the dead were taxed to enhance the comforts of the living; and many was the tent whose centre table, covered with a fringed cloth, and temptingly spread with biscuits, sweetmeats, and sherbet, was the stately monument of some departed Armenian!. Grave-stones steadied the poles which supported the swings-divans, comfortably overlaid with cushions, were but chintzcovered sepulchres - the step that enabled the boy to reach his seat in the merry-go-round was the earth which had been heaped upon the breast of the man whose course was run - the same trees flung their long shadows over the sports of the living and the slumbers of the dead-the kibaub merchants had dug hollows to cook their dainties under the shelter of the tombs-and the smoking booths were amply supplied with seats and counters from the same wide waste of death.

On one side, a slender train of priests were committing a body to the earth, and mingling their lugubrious chant with the shrill instru. 
ments of a party of dancers; on the other, a patrol of dismounted lancers were threading among the many-coloured tents, in order to maintain an order which the heavy-witted Armenians lacked all inclination to break.

I never saw a set of people who bore so decidedly the stamp of having been born to slavery as the Armenians: they seem even to love the rattle of their.chains; they have no high feeling, no emulation, no enthusiasm, no longing for " a place among the nations ;" no aspirations after the bright and the beautiful; no ideas, in short, beyond a pitiful imitation of their Moslem masters, whom they consider as the ne plus ultra of all perfection.

The appearance of the upper class of Armenians I have already described. Give them a more becoming head-dress, and their costume is surpassingly graceful; but their advantages are all external; their dreams are all of piastres; they have no soul. If you talk to them of their subjection to the Osmanli, what do they reply? " All that you say may be very true, but it does not concern me - my affairs are in a most prosperous condition."...

It is impossible to make them sensible of their own social position; they listen, twirl their mustachioes, flourish their white handkerchiefs, replenish their chibouks, utter from time to time "pekké," (very well), with an inane smile, and 
ultimately walk away, as well satisfied with themselves and with their tyrants as though the subject were one of the most irrelevant nature.

From this sweeping accusation of apathy and self-depreciation, even after many months passed in the East, I can except only one individual ; but that one is indeed a rare and a bright example to the rest of his countrymen. To those travellers who have visited Constantinople, and who have had the pleasure and advantage of his acquaintance, I need scarcely say that I allude to $M$. Nubar, the eminent merchant of Galata, whose extensive information, sound judgment, and habitual courtesy, render his friendship extremely valuable to those who are fortunate enough to secure it.

To return, however, to the festival of the Champ des Morts, from which I have digressed. Every hundred yards that we advanced, the scene became more striking. One long line of diminutive tents formed a temporary street of eating-houses; there were kibaubs, pillauf, fritters, pickled vegetables, soups, rolls stuffed with fine herbs, sausages, fried fish, bread of every quality, and cakes of all dimensions. Escaping from this too savoury locality, we found ourselves among the sherbet venders, whose marquees, lined with blue or crimson, were pitched with more precision and regard 
to comfort and convenience than those of the restaurateurs. Mirrors, bouquets, and a display of goblets of all shapes and sizes, were skilfully set forth in many of them; some even indulged in the luxury of pictures, which were universally-glaring and highly-coloured French prints of female heads, of the most common description; and in these tents chairs and cushions were alike provided for the guests; while in one corner stood the mangal, ready to supply the necessary fragment of live coal for igniting the chibouk.

Scattered among these more assuming establishments were the stands of the itinerant merchants, whose little cupolaed fountains threw up a slender thread of water to the accompaniment of a tinkling sound, produced by the contact of half a dozen thin plates of metal; while a circle of sherbet glasses, filled with liquids of different colours, and interspersed with green boughs, and suspended lemons, looked so cool and refreshing that they were more tempting by far than the aristocratic establishments of the marquee owners. Here and there a flat tomb, fancifully covered with gold-embroidered handkerchiefs, was overspread with sweetmeats and preserved fruits; while, in the midst of these rival establishments, groups of men were seated in a circle, wherever a little shade could be obtained, smoking their long pipes in silence, 
with their diminutive coffee-cups resting on the ground beside them. The wooden kiosk overhanging the Bosphorus was crowded ; and many a party was snugly niched among the acacias, with their backs resting against the tombs, and the sunshine flickering at their feet.

But the leading feature of the festival was the Armenian dance, that was going forward in every direction, and which was so perfectly characteristic of the people that it merits particular mention. A large circle was formed, frequently consisting of between forty and fifty individuals, (chance comers falling in as they pleased without question or hindrance) holding each other by the hand, or round the neck, and wedged closely together so as to form a compact body; the leader of the dance being the only one who detached himself from the rest, and held the person next to him at arm's length. In the centre of the ring stood, and sometimes danced, the musician, whose instrument was either a species of small, cracked guitar, with wire strings, which he struck with very slender regard to either time or tune; or a bagpipe precisely similar to that of Scotland, but not played in the same spirit-stirring style, the Armenian performer making no attempt at any thing beyond noise, and never by any accident forming three consecutive notes which harmonized; but his hearers were not fastidious, and the music 
was, at least, in good keeping with the dance. Beside the minstrel, such as I have described him, moved the buffoon of the company, who also, by some extraordinary and perfectly Armenian concatenation of ideas, acted as Master: of the Ceremonies.

The leader flourished a painted muslin handkerchief, while he lifted up first one foot and then the other, as fowls do sometimes in a farmyard; poising the body on one leg for an instant, and then changing the position. This movement was followed by the whole of the party with more or less awkwardness ; and thus hopping, balancing, and shifting their feet, they slowly worked round and round the circle, without changing either the time or the movement for several consecutive hours; the different individuals falling in and out of the ring as their inclination prompted, without disturbing in the slightest degree the economy of the dance. There was nothing exclusive in these Terpsichorean circles, where the smart servingman's neck was clasped by the sinewy hand of the street-porter, and where the embroidered Albanian legging and European shoe were placed in juxtaposition with the bare limb and heelless slipper. There must have been at least a dozen of these dances going forward in the fair, (for such I may truly call it), with a perseverance and solemnity perfectly astonishing;

voL. I.

B B 
when it is remembered that many of the individuals thus engaged had walked five and six leagues to share in the festival, and would have no resting-place but the earth whereon to sleep away their fatigue.

Great was the commerce of the water-venders, who traversed the crowd in every direction, with their classically formed earthen jars upon their shoulders, and their crystal goblets in their hands, who, for a couple of paras, poured forth a draught of sparkling water, which almost made one thirsty to look at it; and were as particular and punctilious in cleansing the glass after every customer, as though they were under the surveillance of his successor.

A few, a very few, of the revellers had indulged in deeper potations, and were exhibiting proofs of their inebriety in their unsteady gait and uncertain utterance; but intemperance is not yet the common vice of the East; although it bids fair in time to become such. A very talented and distinguished individual, with whom I was lately conversing on the subject of the different degrees of civilization attained by particular nations, said of the Russians that they had commenced with champagne and balletdancers. Glorious was it, therefore, for the half dozen Armenians who were staggering among the crowd, to have profited as far as they could by so brilliant an example. Being 
intoxicated is, according to the Eastern phraseology, being à la Frankia.

Apart from the crowd were wrestling-rings, where the combatants exhibited their prowess precisely after the fashion of the Ancient Romans; and on all sides were bands of Bohemians, as dark-eyed and as voluble as the gipsies of Europe.

The festival lasted three days, and not a single hand nor voice was raised in violence during the whole period; when, as if resolved to vindicate themselves from the aspersion of utter insensibility, the Catholic and Schismatic sects terminated their sports with a regular fight, in front of an Armenian church in Galata. The Schismatic party were returning to the place of embarkation in order to pass over to Constantinople, and singing at the pitch of their voices, at the precise moment when a priest of the opposite sect was performing mass in the church. A messenger was despatched to the revellers to enforce silence until they had quitted the precincts of the chapel; but his errand was a vain one; the Schismatics were not to be controlled; a crowd collected - the merits of the case were explained-the Catholics became furious, and insisted on the instant departure of the intruders-the Schismatics waxed valiant, and refused to move-and, finally, after a fight in which many blows were given and received, the Turks

в в 2 
stepped in as mediators, and carried off a score of the combatants to Stamboul, where they were detained for the night, fined a few piastres, and dismissed like a set of lubberly schoolboys, who had wound up a holyday with a boxingmatch! 


\section{CHAPTER XXII.}

The Mosques at Miduight-Baron Rothschild-Firmans and OrdersA Proposition-Masqueradiug-St. Sophia by Lamplight-The Congregation-The Mosque of Sultan Achmet-Colossal Pillars-Return to the Harem-The Chèik-Islam-Count Bathiany-The Party-St. Sophia by Daylight - Erroneous Impression - Turkish ParadisePiety of the Turkish Women-The Vexed Traveller-Disappoin tment-Confusion of Architecture - The Sweating Stone - Women's Gallery - View from the Gallery - Gog and Magog at Constantinople - The Impenetrable Door-Ancient Tradition - Leads of the Mosque-Gallery of the Dome-The Doves - The Atmeidan-The Tree of Groans- The Mosque of Sultan Achmet-Antique VasesHistorical Pulpit-The Inner Court-The Six Minarets-The Mosque of Solimaniè - Painted Windows - Ground-plan of the Principal Mosques-The Treasury of Solimaniè- Mausoleum of Solyman the Magnificent-Model of the Mosque at Mecca - Mausoleums in General-Indispensable Accessories-T'lie Medresch-Mosque of Sultan Mahınoud at Topp-hannè.

Althougil I am about to describe to my readers a morning at the mosques, I must nevertheless first conduct them into the mosques at midnight, by recounting a visit to St. Sophia and Sultan Achmet, which I have hitherto forborne to mention, in the hope (since realized) of being enabled, ere my departure from Constantinople, both to form and to impart a better idea 
of these magnificent edifices than my first adventurous survey had rendered me capable of doing.

During a visit that I made to a Turkish family, with whom I had become acquainted, the conversation turned on the difficulty of obtaining a Firman to see the mosques; when it was stated that Baron Rothschild was the only private individual to whom the favour had ever been accorded: (probably upon the same principle that the Pope instituted the order of St. Gregory, and bestowed the first decoration upon the Hebraic Crœsus) and that travellers were thus dependent on the uncertain chance of encountering, during their residence in Turkey, some distinguished person to whom the marble doors were permitted to fall back.

In vain I questioned and cross-questioned; I failed to obtain a ray of hope beyond the very feeble one held out by this infrequent casualty ; and I could not refrain from expressing the bitterness of my disappointment, with an emphasis which convinced my Musselmaun hearers that I was sincere.

Hours passed away, and other subjects had succeeded to this most interesting one, when, as the evening closed in, I remarked that - Bcy, the eldest son of the house, was carrying on a very energetic sollo voce conversation with his venerable father; and I was not a little asto- 
nished when he ultimately informed me, in his imperfect French, that there was one method of visiting the mosques, if I had nerve to attempt it, which would probably prove successful; and that, in the event of my resolving to run the risk, he was himself so convinced of its practicability, that he would accompany me, with the consent of his father, attended by the old Kiära, or House-steward; upon the understanding (and on this the grey-bearded Effendi had resolutely insisted) that in the event of detection it was to be sauve qui peut; an arrangement that would enable his son at once to elude pursuit, if he exercised the least ingenuity or caution.

What European traveller, possessed of the least spirit of adventure, would refuse to encounter danger in order to stand beneath the dome of St. Sophia? And, above all, what wandering Giaour could resist the temptation of entering a mosque during High Prayer?

'These were the questions that I asked myself as the young Bey vowed himself so gallantly to the venture, (to him, in any case, not without its dangers) in order to avert from me the disappointment which I dreaded.

I at once understood that the attempt must be made in a Turkish dress; but this fact was of trifling importance, as no costume in the world lends itself more readily or more conveniently to the purposes of disguise. After 
having deliberately weighed the chances for and against detection, I resolved to run the risk; and accordingly I stained my eyebrows with some of the dye common in the harem; concealed my female attire beneath a magnificent pelisse, lined with sables, which fastened from my chin to my feet; pulled a fèz low upon my brow; and, preceded by a servant with a lantern, attended by the Bey, and followed by the Kiära and a pipe-bearer, at half-past ten o'clock I sallied forth on my adventurous errand.

We had not mentioned to either the wife or the mother of the Bey whither we were bound, being fearful of alarming them unnecessarily; and they consequently remained perfectly satisfied with the assurance of the old gentleman, that I was anxious to see the Bosphorus by moonlight; though a darker night never spread its mantle over the earth.

I am extremely doubtful whether, on a less exciting occasion, I could have kept time with the rapid pace of my companion, over the vile pavement of Constantinople ; as it was, however, I dared not give way, lest any one among the individuals who followed us, and who were perhaps bound on the same errand, should penetrate my disguise.

"If we escape from St. Sophia unsuspected," said my chivalrous friend, "we will then make another bold attempt; we will visit the mosque of 
Sultan Achmet; and as this is a high festival, if you risk the adventure, you will have done what no Infidel has ever yet dared to do; but I forewarn you that, should you be discovered, and fail to make your escape on the instant, you will be torn to pieces."

'This assertion somewhat staggered me, and for an instant my woman-spirit quailed; I contented myself, however, with briefly replying : "When we leave St. Sophia, we will talk of this," and continued to walk beside him in silence. At length we entered the spacious court of the mosque, and as the servants stooped to withdraw my shoes, the Bey murmured in my ear : "Be firm, or you are lost!" - and making a strong effort to subdue the feeling of mingled awe and fear, which was rapidly stealing over me, I pulled the fèz deeper upon my eye-brows, and obeyed.

On passing the threshold, 1 found myself in a covered peristyle, whose gigantic columns of granite are partially sunk in the wall of which they form a part; the floor was covered with fine matting. and the coloured lamps, which were suspended in festoons from the lofty ceiling, shed a broad light on all the surrounding objects. In most of the recesses formed by the pillars, beggars were crouched down, holding in front of them their little metal basins, to receive the paras of the charitable; while servants 
lounged to and fro, or squatted in groups upon the matting, awaiting the egress of their employers. As I looked around me, our own attendant moved forward, and raising the curtain which veiled a double door of bronze, situated at mid-length of the peristyle, I involuntarily shrank back before the blaze of light that burst upon me.

Far as the eye could reach upwards, circles of coloured fire, appearing as if suspended in mid-air, designed the form of the stupendous dome; while beneath, devices of every shape and colour were formed by myriads of lamps of various hues : the Imperial closet, situated opposite to the pulpit, was one blaze of refulgence, and its gilded lattices flashed back the brilliancy, till it looked like a gigantic meteor!

As I stood a few paces within the doorway, I could not distinguish the limits of the edificeI looked forward, upward - to the right hand, and to the left-but I could only take in a given space, covered with human beings, kneeling in regular lines, and at a certain signal bowing their turbaned heads to the earth, as if one soul and one impulse animated the whole congregation; while the shrill chanting of the choir pealed through the vast pile, and died away in lengthened cadences among the tall dark pillars which support it.

And this was St. Sophia! To me it seemed 
like a creation of enchantment - the light--the ringing voices - the mysterious extent, which baffled the earnestness of my gaze - the ten thousand turbaned Moslems, all kneeling with their faces turned towards Mecca, and at intervals laying their foreheads to the earth - the bright and various colours of the dresses - and the rich and glowing tints of the carpets that veiled the marble floor-all conspired to form a scene of such unearthly magnificence, that I felt as though there could be no reality in what I looked on, but that, at some sudden signal, the towering columns would fail to support the vault of light above them, and all would become void.

I had forgotten every thing in the mere exercise of vision;-the danger of detection-the flight of time-almost my own identity - when my companion uttered the single word " GelCome" - and, passing forward to another door on the opposite side of the building, I instinctively followed him, and once more found myself in the court.

What a long breath I drew, as the cold air swept across my forehead! I felt like one who has suddenly stepped beyond the circle of an enchanter, and dissolved the spell of some mighty magic.

"Whither shall we now bend our way?" asked my companion, as we resumed our shoes. 
"To Sultan Achmet,"- I answered briefly. I could not have bestowed many words on my best friend at that moment; the very effort at speech was painful.

In ten minutes more we stood before the mosque of Sultan Achmet, and, ascending the noble flight of steps which lead to the principal entrance, we again cast off our shoes, and entered the temple.

Intinitely less vast than St. Sophia, this mosque impressed me with a feeling of awe, much greater than that which I had experienced in visiting its more stately neighbour-four colossal pillars of marble, five or six feet in circumference, support the dome, and these were wreathed with lamps, even to the summit; while the number of lights suspended from the ceiling gave the whole edifice the appearance of a space overhung with stars. We entered at a propitious moment, for the Faithful were performing their prostrations, and had consequently no time to speculate on our appearance; the chanting was wilder and shriller than that which I had just heard at St. Sophia ; it sounded to me, in fact, more like the delirious outcry, which we may suppose to have been uttered by a band of Delphic Priestesses, than the voices of a choir of uninspired human beings.

We passed onward over the yielding carpets, which returned no sound beneath our footsteps: 
and there was something strangely supernatural in the spectacle of several human beings moving along, without creating a single echo in the vast space they traversed. We paused an instant beside the marble-arched platform, on which the muezzin was performing his prostrations to the shrill cry of the choir;-we lingered another, to take a last look at the kneeling thousands who were absorbed in their devotions; and then, rapidly descending into the court, my companion uttered a hasty congratulation on the successful issue of our bold adventure, to which I responded a most heartfelt 'Amen'-and in less than an hour, I cast off my fèz and my pelisse in the harem of -Effendi, and exclaimed to its astonished inmates:- "I have seen the mosques!."

Knowing what I now know of the Turks, I would not run the same risk a second time, though the Prophet's Beard were to be my recompense. There are some circumstances in which ignorance of the extent of the danger is its best antidote.

But the feeling that remained on my mind was vague even to pain; I had seen St. Sophia, it is true, and seen it in all the glory of its million lamps; I had beheld it at a moment when no christian eye had ever heretofore looked on it; and when detection would have involved instant destruction. I had lifted aside the veil 
from the Holy of Holies-witnessed the prostration which followed the thrilling cry of "Allah Il Allah !"- -and polluted, with the breath of a Giaour, the atmosphere of the True BelieversI had looked upon the Chèik-Islam, as he stood with his face turned Mecca-ward, his pale brow cinctured with gold, and his stately figure draped in white cachemere-and I had stood erect when every head was bowed, and every knee bent at the name of the Prophet; but still I had no definite idea of the mosque of St. Sophia ; on the contrary, the wish that I had formerly felt to visit it grew to a positive craving from the hour in which I found myself at midnight beneath its fire-girdled dome, and glanced out into the deep and mysterious darkness beyond; and it was not until months afterwards that it was satisfied, when the arrival of Count Bathiany, an Hungarian nobleman, brother to the Princess Metternich, gave an opportunity to the curious of indulging their lion-hunting propensities.

The party assembled at half-past ten in the morning at one of the gates of the city, near the Seraglio wall, known by the name of "The Gate of the Garden." There were horsemen and pedestrians-ladies in arabas, and on foot - spruce attachés, grave elderly gentlemen, anxious antiquaries, officers of the navy, dragomen, foreign nobles, native servants, and a 
motley train of sailors and attendants, carrying the slippers of their several masters.

But if the eye were confused by the number of objects by which it was attracted as our party passed, procession-like, though the narrow streets, amid the comments and not unfrequently the scowls of the Turks, who bear but impatiently this licensed profanation of their temples; the ear was infinitely more so by the confusion of languages which assailed it on all sides; here, two Russians almost set your teeth on edge as they exchanged a few sentencesthere, a couple of Germans deluded you for the first moment into a belief that they were conversing in English-on one side, a dark-eyed stranger begged your pardon in his low soft Italian, for an awkwardness of which you were not conscious, and thus gave himself an opportunity of addressing you during the morning, without rudeness-and on the other, two smart midshipmen laughed out in the lightness of their hearts words which told of home, because they were breathed in the language of your own land-while a constant chorus of Turkish, Greek, and Arab, was kept up by the attendants in the rear.

At length we reached St. Sophia; and I felt my heart beat quicker, as I once more traversed the flagged court, and passed the elegant fountain, at which the Faithful perform their ablu- 
tions; with its projecting octagonal roof, its marble basin, and its covering of close iron network, to protect the spring from the pollution of the birds.

At the entrance of the peristyle to which I have before alluded, we put on the slippers we had provided, and, as soon as we had all passed, the doors were closed.

How different was the aspect of every object around me from that which it wore on my last visit! Then, all was refulgent with light; and now, a sacred gloom hung upon the dark walls, and floated like a veil about our path. Few were they who did not pass on in silence; for there is a power and a sublimity in scenes like the one I am attempting to describe, which overawe for awhile even the most.vulgar minds; while to the susceptible and contemplative the spell is deepened a thousand-fold.

One burst, rather of sound than speech-the wordless tribute of irrepressible admirationheralded our passage across the block of porphyry upon which close the interior doors of the mosque; and in less than a moment the richly carpeted floor of marble, porphyry, jasper, and verdantique, was mosaiced with groups of gazers throughout its whole extent. Some stood riveted to the spot on which they had first halted, as if touched by the wand of an enchanter, and scarcely stirring a limb in the excess of their 
absorbing contemplation; others hurried rapidly along, as though breathless with eager and impatient curiosity - one tall, pale man, with amber-coloured mustachioes and long thin fingers, was already taking notes, with his little red book resting against the boots that he carried in his hand; and a couple of antiquaries were just commencing a dispute sotto voce relatively to some pillars of Egyptian granite on the left hand side of the temple.

Nor were the Imams idle; for they had instantly detected the unhandsome intrusion of one traveller with his boots on; an insult so great, that no Moslem can tolerate it ; and they were busily employed in compelling their removal: accompanying the ceremony with certain epithets addressed to the Giaour, with which, if he were unfortunate enough to understand them, he had no opportunity of feeling flattered.

Our party were not, however, the only tenants of the vast pile. A group of Ulemas were engaged in prayer as we entered, nor did they suffer our presence to interfere with their devotions; and almost in the centre of the floor knelt a party of women similarly engaged, while a couple of children, who had accompanied them, were chasing each other over the rich carpets.

An erroneous impression has obtained in voL. I.

c C 
Europe that females do not attend, or rather, I should perhaps say, are not permitted to enter, the mosques; this, as I have just shewn, is by no means the case; the entrance is forbidden to them only during the midnight prayer. And, in like manner, I had been taught to believe, before I visited the country, that the Turks denied to their women the possession of souls : this is as false a position as the other. It is true that the lordly Moslem claims a paradise apart; where Hourii are to wreathe his brow with everblooming flowers - pour his sherbet in streams of perfume into its crystal vase - and fill his chibouk with fragrance.* But, amid these voluptuous dreams, he does not quite overlook the eternal interests of his mere earthly partner; I do not believe that her future enjoyments are as clearly defined as those which he arrogates to himself - there is a little harem-like mystery flung over the destiny that awaits her; but, meanwhile, he does not altogether shut her out from the promise of a hereafter, from which he himself anticipates so full a portion of felicity.

The Turkish women are intuitively pious; the exercises of religion are admirably suited to their style of existence. In the seclusion of the

- I ain aware that I may here be taxed with an anachronism, and reminded that in the days of Mahomet the use of tobacco was altogether unknown in Turkey; but $\mathbf{I}$, nevertheless, maintain my position, being perfectly convinced that the Hourii would now beckon in vain to a paradise of which the chibouk did not form a feature. 
harem the hour of prayer is an epoch of unwearying interest to the whole of its inhabitants; and there is something touching and beautiful in the humility with which, when they have spread their prayer-carpets, they veil themselves with a scarf of white muslin, ere they intrude into the immediate presence of their Maker.

Being aware of all this, the appearance of females in the mosque of St. Sophia did not produce the same effect upon me as upon many of the party. Those who were lately from Europe could scarcely believe their eyes; and when, in reply to the remark of a person who stood near me, expressing his astonishment at such an apparition, I explained to him that the presence of females in the different mosques was of constant and hourly occurrence, he looked so exceedingly annoyed at the sweeping away of his ancient prejudices, that I verily believe he thought the deficiency of the whole female Empire of Turkey must be transferred to my own little person, and that I, at least, could have no soul.

Upon the whole, the first view of St. Sophia disappointed me; I had carried away an idea of much greater extent; spacious as it was, I could now see from one extremity of the wide edifice to the other-I was no longer bewildered by the blaze of innumerable lights - and I know not

c c 2 
wherefore, but I regretted the mysterious indistinctness of outline which had thralled me during my midnight visit.

Ignorant as I am also of architecture as a science, I have a sufficient perception of the beautiful and the symmetrical, to make me lament the incongruous medley of different orders and materials by which I was surrounded. What gigantic pillars encircle the dome!What individual treasures are collected together! But with what recklessness are they forced into juxtaposition! Columns of varying sizes and proportions ; some of Egyptian granite, others of porphyry, others again of scagliola, and various precious marbles, are scattered, like the fragments of many distinct buildings, throughout the whole body of the edifice. 'The eye is bewildered, and the mind remains unsatisfied.

Eight of the porphyry pillars are relics of the temple of Heliopolis ; while those of verd-antique are from that of Ephesus. The walls are lined with marble, jasper, porphyry, and verd-antique, to the height of a gallery which surrounds the temple; and which, like the base of the building, is floored with rich marbles, and supported by plain columns of the same material. But the dome, which was formerly adorned with minute mosaics, was white-washed when the 'Turks converted St. Sophia into a mosque; and the 
original richness of the design is now only to be deciphered in spots where the plaster has fallen away; added to which, the inferior Imams attached to the building make a trade of the fragments of mosaic that they are continually tearing down, and which are eagerly bought up by travellers, who thus encourage a Vandalism whose destructive effects are irreparable.

Before we ascended to the gallery, we were introduced to one of the miracles of the place, in the shape of a column; a portion of whose surface is cased with iron, in one part of which a deep cavity is worn away beneath the metal ; and into this orifice the visiter is invited to insert his finger, in order to convince himself of the humidity of the marble. This column is called by the Imams " the Sweating Stone;" but if the indignation of the inanimate matter at the transformation of a Christian temple into a Mahommedan mosque have really reduced it to a state of perpetual and palpable perspiration, I am under the necessity of confessing that the miracle was not wrought for me; for, on making the trial, I was conscious only of an extreme chill.

Hence we ascended by a very dilapidated and crumbling spiral stair to the gallery, devoted originally to the use of the women, and capacious enough to contain several hundreds; 
and here the mosaic merchants plunged their hands into their breasts, and from amid the folds of their garments drew forth some thousands of the gilt and coloured stones which they had torn away from the elaborately-ornamented dome,

These were soon disposed of, and then we were permitted to contemplate at our ease the marvels of the mighty pile, with its vast uncumbered space, its bronzed columns, (many of them clamped with iron to enable them to resist more powerfully the ravages of time,) and the huge, shapeless, mystic-looking masses of dark shadow immediately beneath the dome, which, after you have lost yourself in a thousand vague conjectures on their nature and purport, turn out to be nothing more than the mere daubing of some journeyman painter for the purpose of effacing two mighty cherubim, that, in days of yore, pointed to the Christian votary the way to Heaven, but which now, in the dim twilight of the place, look like familiar spirits, shapeless and grim, guarding the accumulated relics of the days of paganism, congregated beneath them.

The view from this gallery, at the upper extremity of the mosque, is extremely imposing; from that point you take in, and fecl, all the extent of the edifice, whose effect is rendered the more striking, from the fact that it is en- 
tirely laid bare beneath you, being totally free from the divisions and subdivisions which in Catholic chapels are necessary for the location of the different shrines. Plain and unornamented, save by the casing of marble already alluded to, the walls tower upward in severe beauty, until they reach the base of the stately dome, which is poized, as if by some mighty magic, on the capitals of a circle of gigantic and rudely fashioned pillars; immediately beneath you are the columns that support the gallery in which you stand, throughout the whole extent of the temple; while on your left hand the marble pulpit, with its flight of noble steps, shut in by a finely sculptured door of the same material, and on your right the Imperial closet, with its gilded lattices, complete the detail of the picture.

The two huge waxen candles occupying the sides of the arched recess, or milhrab, at the eastern end of the building, are lighted every night, and last exactly twelve months; they are the very Gog and Magog of wax-chandlery, and must be at least eighteen inches in circumference.

In making the tour of the gallery, we came upon a door that had been stopped with masonry; the frame into which it had originally fitted is of white marble, and remains quite perfect. There are traces of violence on the 
brick-work, which appears to have been secured by some powerful cement that has indurated with age, until it has acquired the solidity of stone, and has become capable of resisting any ordinary effort to remove it; and this door is the second miracle of St. Sophia.

The legend runs that the united attempts of all the masons of Stamboul are powerless against the rude masonry that blocks the entrance of this passage, by reason of a wondrous and most potent talisman, which human means have as yet failed to weaken; but that it conducts to an apartment in which a Greek Bishop is seated before a reading-desk perusing an open volume of so holy a nature, that no Moslem eye must ever rest upon it. Nor does the tradition end here, for both the Turks and Greeks have a firm faith in the prophecies which have been made, that St. Sophia will one day revert to the Christians, on which occasion the walled-up Bishop will emerge from his concealment, and chant a solemn high mass at the great altar.

The latter portion of the legend would imply that the superstition is of remote origin. I felt glad of this - these mystic imaginings require to be enveloped in the mist of centuries, in order to elevate the ridiculous into the sublime, and to attract our fancy without revolting our reason.

From the gallery we passed out upon the 
leads that cover the inferior cupolas of the building, and screen the mausoleums of the Sultans, and other distinguished personages, whose ashes repose within the holy precincts of St. Sophia; and, after traversing a number of these, and crouching through several low and narrow stene passages, stopping at intervals to contemplate the magnificent views that were spread out beneath us on all sides, and which varied every moment as we advanced, we at length found ourselves at the foot of the ruinous and crumbling stair, or rather ascent, (for the traces of steps are almost worn away) leading to the gallery encircling the dome.

Few of the party were disheartened by the difficulty; and accordingly we slipped and scrambled towards the summit, and resolved to see all the marvels of the place; but when the narrow door which opens from the gallery was flung back by the guide, " a change came o'er the spirit of our dream " - and out of the hundred individuals who were lion-hunting at St. Sophia, there were only seven who possessed nerve enough to make the tour of the dome. Many a fair lady and gallant knight leant for an instant over the slender fence, and looked down into the body of the building while clinging firmly to the rail; gazing on men reduced to the dimensions of pigmies, and wide carpets dwindled to the proportions of a pocket 
handkerchief; but. a brief survey contented them, and they drew back from the dizzy spectacle, with swimming heads and aching eyes.

Seven individuals only, as I have already mentioned, detached themselves from the throng, of which number I was one; and I understood at once the secret of the line of light that had struck me so forcibly on the night of my first visit, when I remarked the clustered lamps which were still attached to the lower railing of the gallery; and I wondered no longer at the sublime effect they had produced, as I perceived the immense height at which they had been placed.

The path we had to follow was about a foot in width, and the slight railing that protected it was secured by iron bars to the wall beyond; but in two places the projecting ledge that formed the passage had lost its horizontal position, and sloped downwards at the outer edge, giving a most uncomfortable projection to the wooden fence; these little inconveniences were, however, amply compensated by the sublime effect of the edifice, seen thus, as it seemed, from the clouds; while the beautiful proportions of the dome became tenfold more evident as the eye took in its whole extent, unbewildered by the immense space which had baffled it from below.

While I stood gazing on the magnificent spec- 
tacle spread out beneath me, a couple of doves winged their tranquil flight across the body of the mosque, to their resting-places on the opposite side of the building. As these birds are held sacred by the Musselinauns, they abound about all their public edifices, and multiply to an extraordinary extent; and their appearance, at a moment when my fancy was awakened, and my feelings excited, by the objects of beauty and of grandeur that surrounded me, produced an effect so powerful as to give birth to a very different train of ideas from those in which $I$ had previously been indulging.*

The tour of the gallery completed our survey of the far-famed St. Sophia; and flinging off the slippers which we had drawn over our shoes, we exchanged the marble floor, covered with yielding carpets, for the steep and stony streets leading to the mosque of Sultan Achmet.

On passing through the Atmeidan (or Place of Horses) on one side of which the mosque is situated, a large plane tree. was pointed out to me, from whose branches Sultan Mahmoud caused several of the principal Janissaries to be hanged, during the destruction of that formidable body, whence it is called by the Turks " the Tree of Groans." The exterior of the build-

- The height of the mosque to the summit of the dome is 185 French feet ; the dome itself, from the gallery to the leads, 47 , and its diameter. 54. 
ing was already familiar to me, as it was from the courtyard of Sultan Achmet that I had seen the procession of the Kourban-Baïram; but of its interior I retained only the same dreamy, indistinct impression which I had carried away on the same occasion from St. Sophia.

The mosque of Sultan Achmet is remarkable for the immensity of the four colossal columns that support the dome, to which I have already alluded; and from the fact that the decree against the Janissaries was unrolled and read by the Chief Priest from its marble pulpit. An air of solemn and religious grandeur is shed over it by the dim twilight that enters through the windows of clouded glass; and it possesses a side gallery, roofed with mosaic and supported by marble pillars, which produces a very pleasing effect ; but beyond this, there is little to attract in its detail, if, indeed, I except the curious and valuable collection of antique vases, many of them richly inlaid with mother-of-pearl, and various coloured stones, (and all of them, as the Imam assured us, authentic) which are suspended from the transverse bars of iron that support the lamps, intermixed with ostrich eggs, bunches of corn in the ear, and similar symbols of abundance.

The inner court of the mosque is truly beautiful, being surrounded by an open cloister sup- 
ported by graceful columns in the Arabian taste, whose capitals resemble clusters of stalactites, and whose slender shafts shoot upwards almost with the lightness of a minaret. In the centre of the court, a stately fountain pours forth its sparkling waters; and on the left hand as you enter is situated the marble balcony from which are read all the Imperial Firmans that possess public interest. Near the gate of entrance, stands an immense block of porphyry of singular beauty, resting upon two masses of stone; on which the dead are exposed previous to their interment; no corpse being permitted to defile the interior of the mosque, and the Sultans themselves having the funeral prayers read over them in the open air.

The mosque of Sultan Achmet is the only one in the eity that has six minarets. This peculiarity arose from the desire of the Sultan to be the first monarch who should build a mosque in his capital, rivalling that of Mecca in the number of its minarets; but, as this could not be done without permission of the Mufti, compliance with the Imperial request was delayed, until steps had been taken to increase those at Mecca to seven, as it was not deemed expedient for any other mosque to enjoy the same privileges as that which is sanctified by the presence of the Prophet's Tomb.

These minarets are arranged with the most 
beautiful taste: two of them are attached to the main body of the building, while the four others pierce through the dense foliage of the stately forest trees which encircle the mosque, with an irregularity singularly graceful. Their transparent galleries of perforated masonry (three in number) girdle the slender shafts with the lightness and delicacy of net-work, and their pointed spires, touched with gold, gleam out like stars through the clear blue of the surrounding horizon.

From the mosque of Sultan Achmet we proceeded to that of Solimaniè, built by Solyman the Magnificent, which is considered to be the most elegant edifice in Stamboul. Its interior is eminently cheerful and attractive; and the splendid windows of stained glass are the spoils of its founder, who, subsequently to a victory obtained over the Persians, bore them away in triumph to enrich the present building, which was then in a state of progression. 'The four pillars that support the dome are slight and well-proportioned; but the four porphyry columns which. form the angles of the temple are the boast of the edifice; they originally served as pedestals to as many antique statues, and are of surpassing symmetry. St. Sophia, amid all the remains which are collected beneath its roof, possesses nothing so fine ; and, independently of these, there is a greater attempt at architectural 
elaboration throughout the whole building, than in either of the mosques that we had previously visited.

The pulpit is very peculiar, being shaped somewhat like the blossom of the aram, which it the more resembles from the fact that the marble whereof it is formed is of the most snowy whiteness; and the great doors of the main entrance are richly inlaid with devices of mother-ofpearl.

Attached to the wall, near the platform of the muezzin, hangs a long scroll of parchment, on which are traced, in black and gold, the groundplans of the five principal mosques in the world - viz. those of Mecca, Medina, Jerusalem, St. Sophia, and Adrianople. It is evidently of great antiquity, and was precisely the description of relic which an antiquary would have valued; while even to the unscientific it was an object of considerable interest.

There is one peculiarity in the mosque of Solimaniè, which it were an injustice to the Turkish government to pass over in silence; and which is in itself so interesting, that $I$ am surprised no traveller has yet made it matter of record.

An open gallery, extending along the whole of the northern side of the edifice, is filled with chests of various sizes and descriptions, piled one on the other, and carefully marked; these 
chests contain treasure, principally in gold, silver, and jewels, to a vast amount; and are all the property of individuals, who, in the event of their leaving the country, family misunderstandings, or from other causes, require a place of safety in which to deposit their wealth. Each package being accurately described, and scrupulously secured, is received and registered at Solimaniè by the proper authorities, and there it remains intact and inviolate, despite national convulsions and ministerial changes. No event, however unexpected, or however extraordinary, is suffered to affect the sacredness of the trust; and no consideration of country, or of religion, militates against the admission of such deposits as may be tendered, by persons anxious to secure their property against casualties.

On one side may be seen the fortune of an orphan confided to the keeping of the Directors of the Institution during his minority; on the other, the capital of a merchant who is pursuing his traffic over seas. All classes and all creeds alike avail themselves of the security of the depository; and, although an individual may fail to reclaim his property for twenty, fifty, or even an unlimited number of years, no seal is ever broken, no lock is ever forced. And despite that this great National Bank, for as such it may truly be considered, offers not only an easy, but an efficient and abundant, mean of supply, no 
instance has ever been known in which government has made an effort to avail itself of the treasures of Solimaniè. As the property is deposited, so is it withdrawn - the proper documents are produced, and the chest or desk is delivered up without the demand of a piastre from those who have acted as its guardians.

The despotism of the Turkish government cannot, in this instance, be subject of complaint ; when, amid all its reverses, and all its necessities, it has ever respected the property thus trustingly confided; while it can scarcely be denied that the admirable integrity, which is the great safeguard of the heaped-up wealth within the walls of the mosque, is at least as worthy of commendation, as the generous liberality which has foreborne to levy a tax upon so valuable a privilege.

From the mosque we passed out by a charming covered walk to the mausoleum of the Magnificent Solyman ; an elegant cupolaed building, with a fluted roof projecting about two feet forward, cased with marble on the outside, and finely painted within in delicate frescoes. An enormous plane tree flings its tortuous branches over the beautiful edifice, which has far more the aspect of a temple than a tomb; and the sunshine falls flickeringly on the marble steps, as it struggles through the fresh leaves. The floor is richly carpeted, and along the centre are

vol. 1.

D D 
ranged the sarcophagi of Solyman the Magnificent and his successor, of Sultan Akhmet, and of the two daughters of the Imperial founder of the mosque. Those of the Sultans are adorned with lofty turbans of white muslin, decorated with aigrettes, and attached to the sarcophagi by costly shawls; the tombs of the Princesses are covered plainly with cachemire of a dark green colour, and are considerably injured by time.

An admirable model of the mosque of Mecca occupied a stand on the right of the entrance, and was an object of general curiosity; it was well executed, and gave an excellent idea not only of the building itself but of the approaches to it. The Tomb of the Prophet occupied the centre of the plan; and the line of road, covered with pilgrims, with its mountain barrier and halting-places, enabled the spectator to form an accurate judgment of the locality:

- In all mausoleums of this description, (and they abound in Constantinople) a priest each day lights up the huge wax candles that are placed at the feet of the sarcophagi, and leaves them burning while he reads a chapter from the Koran. Every part of the building is kept scrupulously clean, and a grain of dust is never suffered to pollute the tombs; the light is freely admitted to the interior, and no feeling of gloom connects itself with these resting-places of the 
dead, which are the very types of luxury and comfort.

Each mausoleum has its peculiar priest, which renders a fact that at first startled me infinitely less surprising; I allude to the immense number of individuals attached to the service of each mosque - St. Sophia alone, as I have been credibly informed, affording occupation to more than three hundred persons!

Three accessories are indispensable to a mosque - a clock, a fountain, and a minaret ; the clock determines the hour of prayer - the fountain enables the Faithful to perform their ablutions-and the minaret supplies the gallery whence the muezzin warns the pious to the temple of Allah.

But, independently of these, every Imperial mosque possesses also its Medresch or College, where the Sophtas are instructed at the expense of the establishment; and its Imaret, or receiving-house for pilgrims, where wayfaring strangers are lodged and fed, and the poor are relieved at a certain hour each day, when a distribution of food takes place to all who think proper to solicit it. In the event of a Kourban, or sacrifice, it is in the Imaret that the animal is put to death, and shared among the needy who throng its entrance to benefit by the pious offering.

The mosque of Sultan Mahmond at ToppD $\mathrm{D} 2$ 
hannè is greatly enhanced in beauty by the splendid fountain and clock-house which he has built on either side of the entrance; and whose gilded lattice-work, and paintings in arabesque are truly Oriental in their taste; this small but elegant mosque is also remarkable for the gilt spires of its minarets, and the stately flight of marble steps by which it is approached.

The ruins of a mosque still remain in Constantinople which was overthrown by an earthquake, wherein the tomb of the Sultan by whom it was built, was covered with a slab of red marble, said to have been the identical stone on which our. Saviour was stretched on his descent from the cross, embalmed, and prepared for the sepulchre!

All the principal mosques are surrounded, and partially overshadowed, by ancient and stately trees, that, in many cases, appear to be coeval with the edifice, and through whose leafy screen portions of the white building gleam out in strong relief; and these are dominated in their turn by the arrowy minarets, which, springing from a dense mass of foliage, cut sharply against the clear sky, and heighten the beauty of the picture.

I have seldom spent a morning of more absorbing interest than that which I passed among the Mosques of Constantinople. 


\section{CHAPTER XXIII.}

Antiquities of Constantinople - Ismäel Effeidi - The Atmeidan-The Obelisk-The Delphic 'Tripod - The Column of Constantine - The Tchernberlè Tasch-The Cistern of the Thousand and One Columns - The Boudroum - The Roman Dungeons_Yèrè-Batan-Seraĩ The Lost Traveller-Extent of the Cistern-Aqueduct of Justinian -Palace of Constantine - Tomb of Heraclius - The Seven Towers - An Ambassador in Search of Truth - Tortures of the Prison - A Legend of thë Seven Towers.

The antiquities of Constantinople are few in number; and when the by-past fortunes of Byzantium are taken into consideration, not remarkably interesting. I shall consequently say little upon the subject, and the rather that more competent writers than myself have already described them; and that these reliques of departed centuries are not calculated to be treated a tutto volo di penna. But, as it is impossible to pass them over altogether in silence, I shall merely endeavour to describe their nature and the effect which they produced upon myself.

Perhaps the most curious remain of by-gone days now existing, and certainly that which is the least known, is Yèrè-Batan-Seraï, literally the "Swallowed up Palace," anciently called 
Philoxmos. I had heard much of this extraordinary old Roman work, but we had repeatedly failed in our attempts to visit it, from the fact of its opening into the court of a Turkish house, whose owner was not always willing to submit to the intrusion of strangers.

We were not, however, fated to leave Constantinople without effecting our purpose; which we ultimately accomplished through the medium of one of the Sultan's Physicians, who provided us with such attendance as insured our success. Ismäel Effendi, Surgeon-in-chief of the Anatomical School attached to the Seraï Bournou, volunteered to become our escort, and we gladly availed ourselves of his kindness. He was a fine, vivacious, intelligent young man, endowed with an energy and mobility perfectly Greek, combined with that gentle and quiet courtesy so essentially Turkish : and we were, furthermore, accompanied by one of his friends, who spoke the French language with tolerable fluency; and a soldier of the Palace Guard, to prevent our collision with the passers-by; a precaution which the rapid and virulent spread of the Plague had rendered essentially necessary.

We first directed our steps to the Atmeidan, or Place of Horses, the ancient race-course of the Romans; in which stands a handsome Egyptian obelisk of red granite, placed there by Theodosius, and resting upon a pedestal of 
white marble, whereon are coarsely represented his victories in very ill-executed alto relievo. The obelisk is sixty feet in height, and elaborately ornamented with hieroglyphics.

Near it are the remains of the Delphic Tripod; the brazen heads of the serpents are wanting; and it is asserted that one of them was struck off by Sultan Akhmet at a single blow of his scimitar.

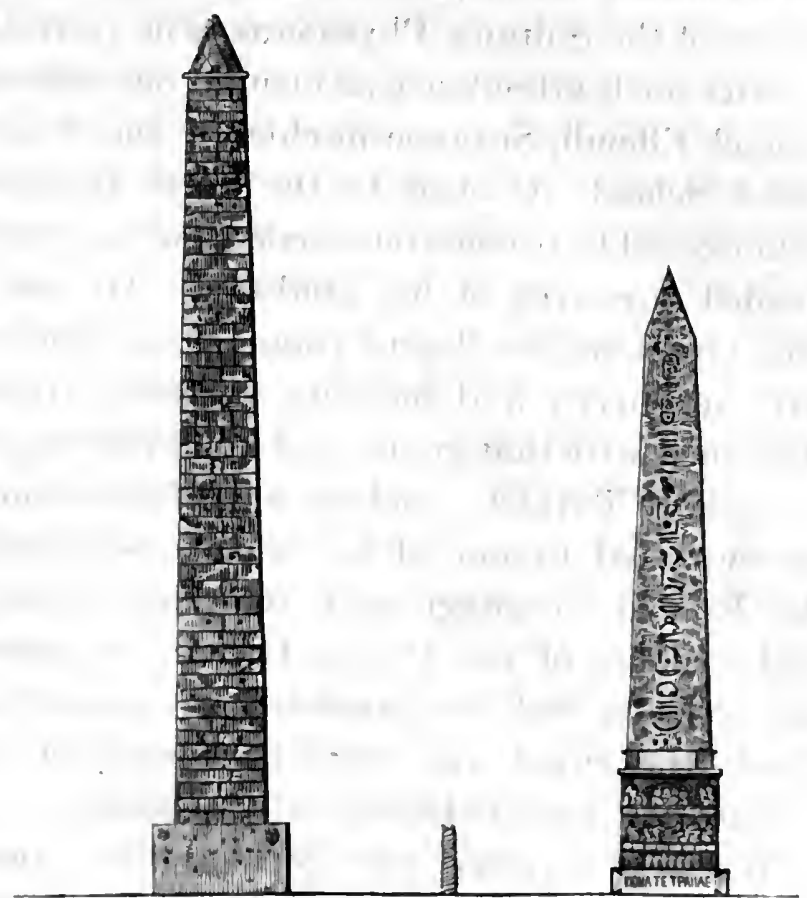

COLUMN OF CONSTANTINE.

TRIPOD.

EQYPTIAN OBEIISK.

The Turks are extremely jealous of this interesting remain, as they have a tradition that, 
when it is either destroyed or displaced, Constantinople will fall once more into the hands and under the power of the Christians ; and so universal is this superstition, that a pretty little girl of about eight years of age, who saw us examining it, approached us, and said earnestly ; "You may look, but you cannot buy this with all your gold, for it is our talisman, and you are Franks and Infidels."

About one hundred paces beyond the Tripod, the lofty monument of Constantine, denuded of the coating of metal by which its coarse masonry is said to have been once concealed, rears its head ninety feet from the earth ; and appears, from its immense height and small circumference, superadded to the apparently careless and insecure manner in which the stones are put together, to stand erect only by a miracle.

But far more curious than either of these is the Tchernberlè Tasch, or Burnt Pillar, situated at a short distance from the Tower of the Seraskier. It was originally brought by Constantine from the Temple of Apollo, at Rome, and was placed upon an hexagonal pedestal, within which were built up several portions of the Holy Cross; whence the small square in which it stood became a place of prayer. When first transported to Constantinople, it was surmounted by a statue of the God, from the chisel of Phidias, of which the head was surrounded by a 
halo. But the conqueror appropriated the figure, and caused to be inscribed beneath it, "The Justice of the Sun to the Illustrious Constantine."

The destruction of the statue is diversely explained by different writers. Genaro Esquilichi declares it to have been destroyed by a thunderbolt; Anna de Comnena asserts that it was overthrown by a strong southerly wind during the reign of Alexius de Comnena, and that it killed several persons in its fall; while other authors mention that it was merely mutilated by the first accident, and utterly ruined by the second. The pedestal bears an inscription now nearly obliterated, which may be thus rendered from the original Greek :

" O Christ, Master and Protector of the World,

I dedicate to Thee this City, subject to Thee;

And the Sceptre, and the Empire of Rome.

Guard the City, and protect it from all evil."

The pillar is ninety feet in height, and the pedestal measures thirty feet at its base; it has suffered severely from fire as well as from time, and a strong wire-work has been carefully erected about it to prevent its falling to pieces, as it is rent and riven in every direction. It is to be deplored that this interesting relic is built in on all sides by unsightly houses.

From the Tchernberle Tasch we proceeded to visit a cistern called by the Turks Bin-VebirDireg, or the "Thousand and One," in allusion 
to the number of columns that support it. It is an immense subterranean, of which the roof is in reality sustained by three hundred and thirty-six pillars of coarse marble, each formed of two or more blocks.

These pillars are now buried to one-third of their height in the earth, the water-courses having been turned, and the cistern dried up, for the purpose of receiving the rubbish which was flung out when the foundations of St. Sophia were laid. It is now occupied by silk-winders, and they have become so accustomed to the sight of visiters that they scarcely suffer you to descend the first flight of steps before they all quit their wheels, and begin shouting for backschish. The channel worn in the stone by the passage of the water that once flowed into the cistern is distinguishable on three different sides of the subterranean, which is lit by narrow grated windows level with the roof; and the echoes, prolonged and flung back by the vaulted recesses, have a sound so hollow and supernatural that they appear like the distant mutterings of fiends.

As we were about to quit Bin-Vebir-Direg, one of the silk-spinners informed us that there was another smaller Boudroum, or subterranean in the neighbourhood, to which he offered to conduct us; honestly admitting, at the same time, that the atmosphere that we should breathe there 
was so unwholesome that few persons ventured to indulge their curiosity by descending into it. Thither we accordingly went, and the less reluctantly as we ascertained by the way that this also had been converted into a spinning establishment, where fifty or sixty persons were constantly employed.

A short walk over the rubbish of an ancient fire brought us to the narrow door of this second subterranean. And we had not descended a dozen steps, ere we were perfectly convinced of the accuracy of the information given to us by the guide. Each felt as though a wet garment had suddenly been wound about him; and the appearance of the miserable beings who were turning the cotton wheels, sufficiently demonstrated the unhealthiness of the atmosphere; they were all deadly white, and looked like a society of recuscitated corses. We had heard a confusion of voices from the moment that we approached the neighbourhood of Bin-Veber Direg, but all was silence within the Boudroum where we now found ourselves; while the blended curiosity and astonishment with which every eye was turned upon us, was a convincing proof that the unfortunates who tenanted it were little used to the sight of strangers.

Immediately that we had descended into the vault, they simultaneously desired us to keep in continual motion during our stay, alleging that 
the exercise consequent on their occupation was their only preservative against destruction ; and confirming the truth of their statement by the melancholy tale of a man who had come a few weeks previously to visit one of their company, and who remained quietly smoking upon his mat for several hours, after which he was seized with lethargy, and died.

As the lower orders of Orientals universally believe every Frank to be, if not actually a Physician by profession, at least perfectly conversant with the "healing art," a group of the pallid wretches by whom we were surrounded immediately began to apply to my father for advice and assistance; when the good-natured Ismäel Effendi volunteered to prescribe for them, and listened with the greatest patience to a list of ailments, engendered by the fetid atmosphere, and quite beyond the reach of medicine.

This cistern, although of considerably less extent than Bin-Vebir-Direg, being supported only by one and thirty pillars, is nevertheless infinitely handsomer, as the columns are at least thrice the circumference of the "Thousand and One," and uncovered to their base; two only are imperfect; and the coup-dail from midway of the stone stair is most imposing.

On emerging from this dim and-vapourfreighted vault, we inquired of the guide whom we had retained, whether he could direct us to 
any other object of interest in that quarter of the city; when, after some hesitation, allured by the promise held out to him of a liberal backschish, he at length admitted that there was a Boudroum about half a mile from thence, which was but little known, and into which no Frank had ever been admitted. Then followed a host of assurances of the danger that he incurred by pointing it out to us, and of which we readily understood the motive; and, after receiving a second promise of reward, he ultimately led the way through one or two narrow streets; when passing under a large doorway, we found ourselves in a dilapidated Khan, where a dozen old men were seated on low stools, winding silk. Here our conductor procured lights, after which he preceded us down a flight of steps, terminating in a second door, whence a short stair descended into an extensive vault, supported by eight double arches of solid masonry, as perfect as though they had only been completed on the previous day.

Traversing this vault, we entered a second, perfectly dark, of which the outer wall was strengthened by four large pillars. At the extreme end of this inner subterranean, we found a flight of ruined stone steps, which we ascended with some difficulty, and, on arriving at the summit of the stair, discovered that we were standing in a dilapidated Roman dungeon. 
From this point several other cells branched off in different directions. The entrance of one, which appeared to be a cachot forcé," was so blocked by the masses of stone that had fallen from the roof, that we were unable to penetrate into it; but on the other side we passed into a range of dungeons, of which the partition walls, at least a foot in thickness, had been torn down. The iron rings by which the prisoners had been chained, still remained, as did also the sleeping places hollowed in the masonry; but the most curious and frightful feature of the locality was a water-course, which; passing along the entire line of cells, emptied itself into a small dungeon, situated under the arched vault that I have already described, and thus offered a ready mean of destruction to the oppressor; and a dreadful and hopeless death to the captive.

I was sincerely glad to leave this gloomy remain of by-past power, and to breathe once more the pure air of Heaven, on my way to YèrèBatan-Serai, where we arrived after a long and very fatiguing walk. After a little hesitation, the door of the Turkish house to which I have elsewhere alluded was opened to us, and, passing through the great entrance hall, we traversed the court-yard, and descending a steep slope of slippery earth, found ourselves at the opening of the dim mysterious Palace of Waters.

The roof of this immense cistern, of which the 
extent is unknown, is supported, like that of Bin Vebir-Direg, by marble columns, distant about ten feet from each other, but each formed from a single block; the capitals are elaborately wrought, and in one instance the entire pillar is covered with sculptured ornaments.

At the period of our visit, Constantinople had been long suffering from dronght, and the water in the cistern was consequently much lower than usual, a circumstance that greatly tended to augment the stateliness of its effect. There was formerly a boat upon it, but it has been destroyed in consequence of the numerous accidents to which it gave rise.

The Kiära of the Effendi who owned the house, had accompanied us to the vault; and he mentioned two adventures connected with it that had taken place within his own knowledge, and which he related to us as having both occurred to Englishmen.

The first and the saddest was the tale of a young traveller, who about six years ago arrived at Constantinople, and in his tour of the capital, obtained permission to see the Yèrè Batan Seraï. The boat was then upon the water; and, not satisfied with gazing on the wonders of the place from land, he sprang into the little skiff, and accompanied by the boatman who was accustomed to row the family in the immediate vicinity of the opening, he pushed off, after having 
received a warning not to be guilty of the imprudence of advancing so far into the interior as to lose sight of the light of day. This warning he was unhappy enough to disregard. .Those who stood watching his progress remarked that he had provided himself with a lamp, and they again shouted to him to beware: but the wretched man was bent upon his purpose ; and having, as it is supposed, induced the boatman, by the promise of a heavy reward, to comply with his wish, the flame of the lamp became rapidly fainter and fainter, and at length disappeared altogether from the sight of those who were left behind; and who remained at their station anxiously awaiting its return. But they lingered in vain-they had looked their last upon the unfortunates who had so lately parted from them in the full rush of life and hope-the boat came no more-and it is presumed that those within it, having bewildered themselves among the columns, became unable to retrace their way, and perished miserably by famine.

I should have mentioned that the spot on which we stood was not the proper entrance to the cistern, of whose existence and situation they are even now ignorant, but an opening formed by the failure of several of the pillars, by which accident the roof fell in, and disclosed the water-vault beneath.

Another similar but less extensive failure of the 
extraordinary fabric in a yard near the Sublime Porte betrayed its extent in that direction; a third took place in the immediate neighbourhood of St. Sophia; and a fourth within the walls of the Record Office; thus affording an assurance that the cistern extended for several leagues beneath the city. Further than this the Constantinopolitan authorities cannot throw any light on its dimensions; and, as far as I was individually concerned, I am not quite sure that this fact did not increase the interest of the locality - the mysterious distance into which man is forbidden to penetrate - the long lines of columns deepening in tint, and diminishing in their proportions as they recede - the sober twilight that softens every object-and the dreamy stillness that lords it over this singular Water Palace, which the voice of man can awaken for a brief space into long-drawn and unearthly echoes, that sweep onward into the darkness, and ere they are quite lost to the ear, appear to shape themselves into words: all combined to invest the spot with an awful and thrilling character, which, to an imaginative mind, were assuredly more than an equivalent for the privilege of determining its limits.

The second local anecdote related to us by the Kiära was that of an Englishman, who, only a few months previous to our visit, had re-

VOL. I.

E E 
quested permission to make use of the little boat that had replaced the one in which the traveller, to whom I have already alluded, had been lost. Many objections were started; and the fate of his unfortunate countryman was insisted upon as the reason of the refusal; but on his repeated promises of prudence, the old Effendi at length consented to his wish; and having lighted a couple of torches, and affixed them to the stern of the boat, the traveller drew out a large quantity of strong twine, which he made fast to one of the pillars, leaving the ball to unwind itself as he proceeded.

As no one could be found who was willing to accompany him, he started alone; and hour after hour went by without sign of his return; until, as the fourth hour was on the eve of completion, the flame of the torches lit up the distance, and was reflected back by the gleaming columns. The wanderer sprang from the boat chilled and exhausted; and, in answer to the inquiries of those about him, he stated that he had progressed for two hours in a straight line, but that he had seen nothing more than what they looked upon themselves-the vaulted roof above his head, the water beneath his feet, and a wilderness of pillars rising on all sides, and losing themselves in the darkness.

This second adventure so alarmed the worthy old Osmanli to whom the boat belonged, that 
he caused it to be immediately destroyed; and visitors are now compelled to content themselves with a partial view of Yèrè-Batan-Serä̈ from the ruined opening.

Marcian's Column, called by the Turks Kestachi, which is situated in the garden of a Turkish house ncar the gate of Adrianople, is a splendid remain, of which the capital is supported by four magnificent eagles. The hexagonal pedestal is ornamented with wreaths of oak leaves, and the height of the shaft is nearly eighty feet.

Of the remains of the Aqueduct of Justinian I have already spoken; and hundreds of beautiful and graceful columns, and thousands of sculptured fragments, are to be seen intermingled with the masonry of the city walls.

The ancient Palace of Constantine, vulgarly named the Palace of Belisarius, stands in that quarter of the city called Balata, a corruption of Balati, "the gate of the palace." It is impossible to visit this curious ruin with any pleasure, as it has been given up to the needy Jews, who have established within its walls a species of pauper barrack, redolent of filth. It is of considerable extent, and principally remarkable for the curious arrangement of its brick-work; there are, however, the remains of a handsome doorway, and outworks of great strength. 
About ten days before I left the country, some workmen, employed in digging the foundation of an outbuilding at the Arsenal, brought to light a handsome sarcophagus of red marble, containing the bodies of Heraclius, a Greek Emperor, who flourished during the reign of Mahomet, and his consort. The two figures representing the Imperial pair are nearly perfect. That of the Emperor holds in one hand a globe, and with the other grasps a sceptre; while the Empress is represented with her crown resting upon her open palm. At their feet are the busts of two worthies, supposed to be portraits of celebrated warriors, but the inscriptions beneath them are nearly obliterated.

Immediately that the identity of the occupants of this lordly tomb was ascertained, orders were given that an iron railing, breast-high, should be erected to protect the relic from injury, the Turks having a tradition that Heraclius died a Mahomedan. The fact is, however, more than doubtful; although it is well known that Mahomet sent him an invitation to abjure Christianity, and to become a 'True Believer; but, at the period of this occurrence, Heraclius was bowed by years, and sunk in sensual enjoyments. Anxious to evade a war with Mahomet, whose successes were then at their height, he despatched an ambiguous reply to the message, and died ere he had given the Musscl- 



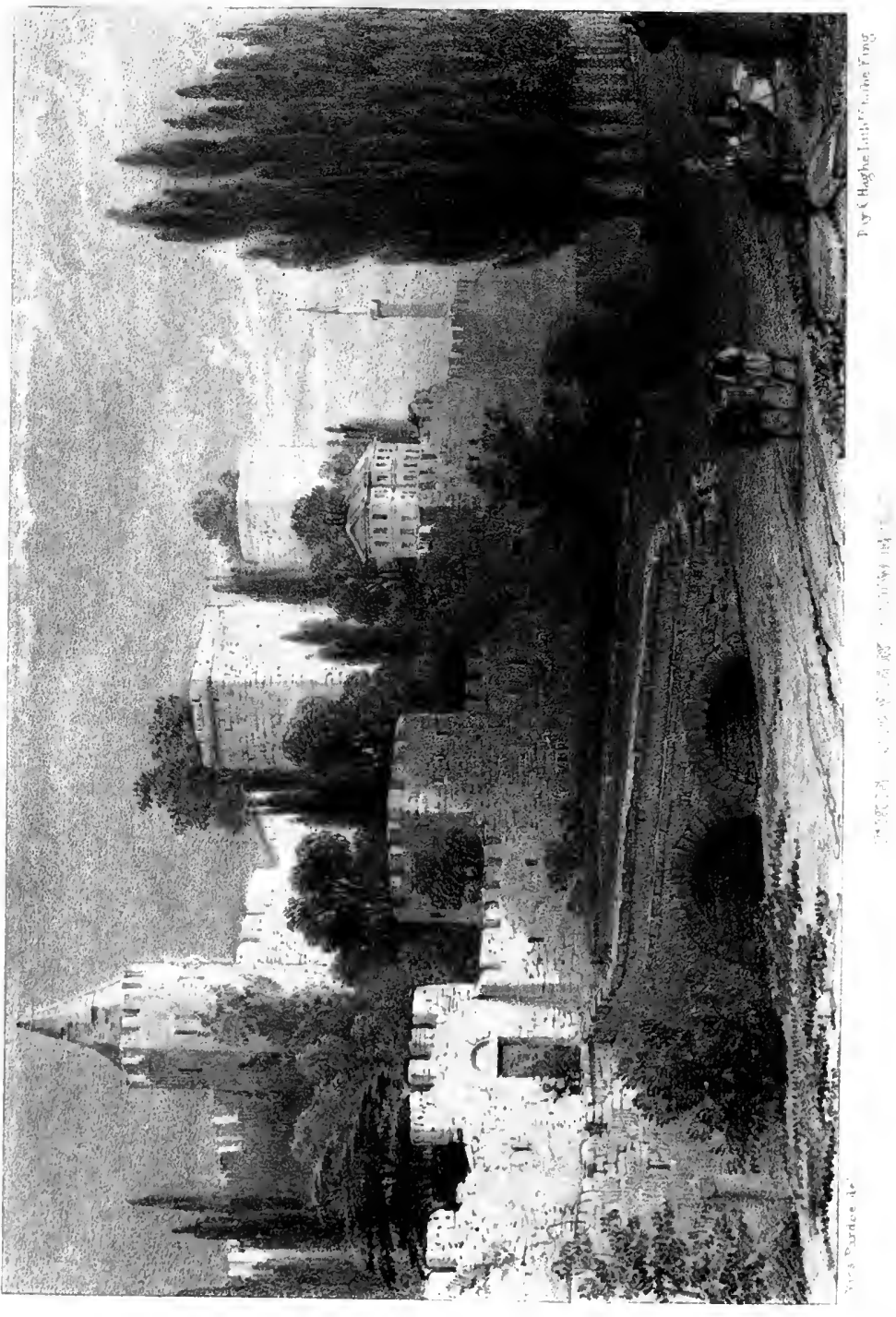


mauns reason to suspect the real motive of his supineness. Hence the Turks claimed the sarcophagus of Heraclius as the tomb of a True Believer; and a marble mausoleum is to be built over it, similar to those which contain the ashes of the Sultans.

The Seven Towers-that celebrated prison of which the very name is a spell of power - are rapidly crumbling to decay, but must continue to be among the most interesting of the antiquities of Constantinople, as long as one stone remains upon another.

Although situated in a populous part of the city, this fortress is, nevertheless, an isolated building; and four of the towers to which it owes its name are destroyed, but of those that still exist, one contains the apartments originally appropriated to state prisoners, and is also the residence of the Military Commanlant and the officers of the garrison. When it ceased to be a state prison for attainted 'Turks, the fortress of the Seven Towers was exclusively reserved for the reception of the Russian Ambassadors, on the occasion of any misunderstanding between the Ottoman and Muscovite courts; and it is almost a ludicrous fact that, during the reign of Mustapha III., His Excellency Count Obrescoff, representative of Her Imperial Majesty, the Empress of all the Russias, not only suffered an imprisonment of three years in 
this fortress, but actually passed several days at the bottom of a dry well, into which it was the Sublime pleasure of the Sultan to cause him to be lowered.

If His Highness acted upon the impression that the Muscovite Minister would succeed during his subterranean sojourn in discovering the moral deity who is said to be concealed therein, there is every reason, from existing circumstances, to believe that the experiment was a failure, or that she declined being withdrawn from her retreat.

Instruments of torture - racks, wheels, and oubliettes-are rife within this place of gloom and horror. One chasm, upon whose brink you stand, is called the "Well of Blood," and is said to have overflowed its margin with the ensanguined stream which was once warm with life - a small court, designated the "Place of Heads," is pointed out as having been cumbered with the slain, until the revolting pile was of sufficient height to enable the spectator to look out from its summit upon the waves of the glittering Propontis; and more than one stone tunnel is shown, into which the wretehed captive was condemned to crawl upon his hands and knees, and there left to die of famine.

But I shall pass by these tales of terror, to narrate a Legend of the Seven Towers, less known than the objects which are exhibited to 
every visiter, and more calculated to interest the reader.

On the declaration of war with Russia made by the Turks in 1786, Baron Bulhakoff, the Russian Minister, despite his representation that the imprisonment of the Muscovite Ambassadors on such occasions had been abolished by treaty, was, nevertheless, sent to the Seven Towers by order of Codza Youssouf Pasha, the Grand Vèzir, with the assurance that treaties were very good things in a time of peace, but mere waste paper in the event of war. 'The discomfited Ambassador was, however, treated with great civility, and was even permitted to select such members of the Legation as he desired should bear him company during his captivity; strict orders being given to the Commandant of the castle to accede to every request of his prisoner which did not tend to compromise his safety; and upon his complaining of the accommodations of the 'Tower, he was moreover permitted to erect a kiosk on the walls of the fortress, whence he had a magnificent view of the Sea of Marmora and its glittering islands, and to construct a spacious and handsome apartment within the Tower itself.

I have already stated that the Commandant was lodged bencath the same roof as his prisoner; but I have yet to tell that he had an only daughter, so young, and so lovely, that she 
might have taken her stand between the two Houri who wait at the portal of Paradise to beckon the Faithful across its threshold, without seeming less beautiful than they. Fifteen springs had with their delicate breathings cpened the petals of the roses since the birth of Rèchèdi* Hanoum, and she had far out-bloomed the brightest blossoms of the fairest of seasons. Her voice, when it was poured forth in song, came through the lattices of her casement like the tones of a distant mandolin sweeping over the waters of the still sea-when you looked upon her, it was as though you looked upon a rose; and when you listened, you seemed to listen to the nightingale.

Rèchèdi Hanoum had never yet poured the scented sherbet in the garden of flowers. Her young heart was as free as the breeze that came to her brow from the blue bosom of the Propontis; and when she heard that a Muscovite Giaour was about to become an inmate of the 'Tower, she only trembled, for she knew that he was the enemy of her country.

Terror was, however, soon succeeded by curiosity. Only a few weeks after the compulsatory domestication of the Ambassador at the Seven Towers, his kiosk was completed; and from her closed casements the young Hanoum

- Mignionetle. 
could see all that passed in the vast apartment of the prisoner.

Her first glance at the dreaded Infidel was transient; but soon she took another, and a longer look; and curiosity was, in its turn, succeeded by sympathy. The Russian prisoner was the handsomest man on whom her eye had ever rested, and it was not thus that she had pictured to herself the dreaded Muscovite. He was unhappy too, for in his solitary moments he paced the floor with hurried and unequal steps, like one who is grappling with some painful memory; and at times sat sadly, with his head pillowed on his hand, and his fingers wreathed amid the wavy hair which encircled his brow; looking so mournful, and above all so fascinating, that the fair Rèchèdi at last began to weep as she clung to her lattice, with her gaze riveted upon him; and to find more happiness in those tears, than in all the simple pleasures that had hitherto formed the charm of her existence.

Little did the young Hanoum suspect that she loved the Giaour. She never dreamt of passion; but, with all the generous anxiety of innocence, unconscious that a warmer feeling than that of mere pity urged her to the effort, she began to muse upon the means of diminishing the irksomeness of a captivity which she was incapable of terminating. 'The first, the 
most natural impulse led her to sweep her hands across the chords of her Zebec; and as she remarked the start of agreeable surprise with which the sound was greeted by the courtly prisoner, her young heart bounded with joy, and the wild song gushed forth in a burst of sweetness which chained the attention of the captive, and afforded to the delighted girl the opportunity of a long, long look, that more than repaid her for her minstrelsy.

During the evening she watched to ascertain whether a repetition of her song would be expected, and she did not watch in vain ; for more than once the Russian noble leant from his casement, and seemed to listen; but he came not there alone; one of his companions in captivity was beside him; and Rèchèdi Hanoum, although she guessed not wherefore, had suddenly become jealous of her minstrelsy, and would not exhibit it before a third person.

On the morrow, an equally graceful, and equally successful effort whiled the prisoner for a time from his sorrows. A cluster of roses, woven together with a tress of bright dark hair, was flung from the casement of the young beauty, at a moment when the back of the stranger was turned towards her. It fell at his feet, and was secured and pressed to his lips, with a respectful courtesy that quickened the pulses of the clonor; but not a glimpse of the 
fair girl accompanied the gift; and it seemed as though the Baron had suspected wherefore, for ere long he was alone in his apartment; and, when he had dismissed his attendants, he once more advanced to the window, and glanced anxiously towards the jealous lattices by which it was overlooked.

There was a slight motion perceptible behind the screen; a white hand waved a greeting; and the imprisoned noble bent forward to obtain a nearer view of its fair owner. For a moment Rèchèdi Hanoum stood motionless, terrified at the excess of her own temerity; but there was a more powerful feeling at her heart than fear; and in the next, she forced away her prison-bars for an instant; and, with the telltale hand pressed upon her bosom, stood revealed to her enraptured neighbour.

From that day the young beauty allowed herself to betray to the captive her interest in his sorrows; she did more; she admitted that she shared them; and ere long there was not an hour throughout the day in which the thoughts of Rèchèdi Hanoum were not dwelling on the. handsome prisoner.

Thus were things situated during two long years, when the death of the reigning Sultan, at the termination of that period, induced the Ambassadors of England and France to demand from his successor, Selim III., the liberty of the 
Russian Minister. The request was refused, for the war was not yet terminated; and the new Sovereign required no better pretext for disregarding the representations of the European Ambassadors, than the continuation of hostilities between the two countries. But Selim had other and more secret reasons for thus peremptorily negativing their prayer; and it will be seen in the suite that they did not arise from personal dislike to the captive Muscovite.

Like Haroun Alraschid of Arabian memory, the new Sultan, during the first weeks of his reign, amused himself by nocturnal wanderings about the streets of the city in disguise; attended by the subsequently famous Hussèin, his first and favourite body-page ; and immediately that he had refused compliance with the demand of the Ambassadors, he resolved on paying an incognito visit to his prisoner at the Seven Towers. As soon as twilight had fallen like a mantle over the gilded glories of Stamboul, he accordingly set forth; and having discovered himself to the Commandant, and enjoined him to secresy, he entered the anti-chamber of the Baron, where he found one of his suite, to whom he expressed his desire to have an interview with the captive Ambassador.

The individual to whom the Sultan had addressed himself recognised him at once; but, 
without betraying that he did so, contented himself with expressing his regret that he was unable to comply with the request of his visitor, the orders of the Sultan being peremptory, that the Baron should hold no intercourse with any one beyond the walls of the fortress.

On receiving this answer, Selim replied gaily that the Sultan need never be informed of the circumstance; and that, being a near relation of the Commandant, and having obtained his permission to have a few minutes' conversation with the prisoner, he trusted that he should not encounter any obstacle either on the part of the Baron himself, or on that of his friends.

The Dragoman, with affected reluctance, quitted the room, to ascertain, as he asserted, the determination of His Excellency, but in reality to inform him of the Imperial masquerade; and in five minutes more the disguised Sultan and his favourite were ushered into the apartment of the Ambassador.

After some inconsequent conversation, Selim inquired how the Baron had contrived to divert the weary hours of his captivity ; and was answered that he had endeavoured to lighten them by books, and by gazing out upon the Sea of Marmora from his kiosk. Bulhakoff sighed as he made the reply, and remembered how much more they had been brightened by the affection of the fair Rèchèdi Hanoum; and he 
almost felt as though he were an ingrate that he did not add her smiles and her solicitude to the list of his prison-blessings.

"The same velume and the same kiosk cannot please for ever;" said the Sultan with a smile; "and you would not, doubtlessly, be sorry to exchange your books against the conversation of your fellow-men; nor your view of the blue Propontis for one more novel. A prison is but a prison at the best, even though you may be locked up with all the courtesy in the world. But your captivity is not likely to endure much longer. Shekiur Allah! - Praise be to God-I am intimately acquainted with the Sultan's favourite; and I know that, had not the meddling ministers of England and France sought to drive the new sovereign into an act of justice, which he had resolved to perform from inclination, you would have been, ere this, at liberty. Do not therefore be induced to lend yourself or your countenance to any intrigue that they may make to liberate you, and which will only tend to exasperate His Highness ; but wait patiently for another month, and at its expiration you will be set free, and restored to your country."

"I trust that you may prove a true prophet-" said the Baron; and his visitors shortly afterwards departed.

The days wore on; the month was almost at 
an end, and yet the captive noble had never ventured to breathe to the fair girl who loved him the probability of his liberation. He shrank from the task almost with trembling, for he felt that even to him the parting would be a bitter one-even to him, although he was about to recover liberty, and country, and friends. What, then, would it be to her? to " his caged bird," as he had often fondly called her-who knew no joy save in his presence-no liberty save that of loving him! As the twilight fell sadly over the sea, and the tall trees of the prison-garden grew dark and gloomy in the sinking light, he remembered how ardently they had both watched for that still hour, soon to be one of tenfold bitterness to the forsaken Rèchèdi Hanoum ; and there were moments in which he almost wished that she had never loved him.

But the hour of trial came at last. Selim had redeemed his word, and Bulhakoff was free. His companions in captivity would fain have quitted the fortress within the hour; but the liberated prisoner lingered. He gave no reason for his delay; he offered no explanation of his motives ; he simply announced his resolution not to quit the Tower until the morrow; and then he shut himself into his chamber, and passed there several of the most bitter hours of his captivity.

Once more twilight lay long upon the waters - the time of tryst was come-the last which the 
beautiful young Hanoum was ever to keep with her lover. She had long forgotten the possibility of his liberation; and when she stole from her chamber to the shadow of the tall cypresses that had so often witnessed their meeting, her heart bounded like her step. But no fond smile welcomed her coming-no reproach, more dear than praise, murmured against her tardiness-Bulhakoff was leaning his head against the tree beside which he stood, and the young beauty had clasped within her own the chill and listless hand that hung at his side, ere with a painful start he awakened from his reverie.

The interview was short; but brief as was its duration it had taught the wretched girl that for her there was no future save one of misery. She did not weep - her burning eye-balls were too hot for tears. She could not weep, for the drops of anguish would have dimmed the image of him whom she had loved, and was about to lose. She made no reply to the withering tidings he had brought, for what had words to do with such a grief as her's? She was like one who dreamt a fearful dream; and when she turned away to regain her chamber, she walked with a firm step, for her heart was broken; and she had nothing now left to do but to veil from her lover the extent of her own anguish, lest she should add to the bitterness of his. 
The morrow came. The Baron turned a long, soul-centered look towards the lattices of his young love, and quitted her for ever; and, ere many weeks were spent, the same group of cypresses which had overshadowed the trystingplace of Rèchèdi Hanoum gloomed above her grave. 


\section{CHAP'TER XXIV.}

Balouclè-TheNew Church-Delightful Road-Eyoub-The Cemetery -The Rebel's Grave-The Mosque of Blood - The Hill of Graves -The Seven Towers-The Palace of Belisarius - The City Walls - Faster Festivities - The Turkish Araba - The Armenian Carriage-Travellers-Turkish Women - Seridjhes-Persians-Irregular Troops-The Plain of Balouclè-Laughable Mistake-Extraordinary Discretion - The Church of Balouclè - The Holy Well Absurd Tradition-The Chapel Vault-Enthusiasm of the GreeksA Pleasant Draught - Greek Substitute for a Bell-Violent Storm.

Our next expedition was to Balouclè, where the Greeks have recently built a small, but elegant church, upon the spot once occupied by a very spacious edifice, which had gone to ruin. The ride, though long and somewhat fatiguing, was most delightful; the road leading us across the hills, to the fair Valley of the Sweet Waters, along the banks of the sparkling Barbyses, past the Imperial kiosks ; and onward to the beautiful village of Eyoub, the stronghold of the Constantinopolitan Turks, wherein they allow no Giaour to reside ; and the marble floor of whose thriceholy mosque no infidel foot has ever trodden. 
The situation of Eyoub is eminently picturesque. It is backed by gently-swelling hills, clothed with trees, where the delicate acacia and the majestic maple are mingled with the scented lime and the dark and rigid cypress, whose blended shadows fall over a thousand graves, and turn away the sunlight from the lettered tombs of many a lordly Musselmaun. Eyoub possesses also a melancholy interest from the fact, that in its beautiful cemetery stands the rude mausoleum of the rebel Ali of Tepeleni who revolted in Albania, wherein are deposited the heads of himself, his three sons, and his grandson. Nor is this all; for a small mosque, almost buried amid tall trees, may be distinguished at the point where the main street sweeps downward to the water's edge, whose modest minaret is painted a dull red from its base to its spire, and which bears the thrilling designation of the "Mosque of Blood."

I have elsewhere mentioned that the Osmanlis do not permit their temples to be desecrated by the admission of the dead beneath their roofs; and this humble pile earned its awful appellation at the siege of Constantinople, when its doors were forced by the combatants, and its narrow floor cumbered with slain. Since that period, its single minaret has been painted as I have described; and it possesses an additional interest from its vicinity to the bleak, naked, tree- 
less hill, whereon were interred all the True Believers who perished at that memorable period, and whose ashes still remain undisturbed.

Nothing can be more romantic than the appearance of the Seven Towers, the remains of the Palace of Belisarius, and the crumbling walls of the city, extending along the whole line of road to Balouclè, like a succession of ruined castles; and overtopped by forest trees, whose bright foliage forms a striking contrast from the grey and mouldering rampart. At intervals, towers thickly overgrown with ivy, and tottering to their fall, raise their fantastic outline against the sky; while the moat is in many places entirely concealed by the wild fig trees, and the dense underwood, that have sprung in wild luxuriance from the rich soil.

At the period of our visit, the Easter festivities were at their height, and the road was covered with groups of travellers, all hurrying towards the same point. There was the gilded araba of the Turkish lady, with its covering of crimson cloth, and its carved lattices; followed by a mounted negro. Then came the bullockcarriage of an Armenian family, gaily painted and cushioned, its oxen half covered with worsted tassels and finery, and glittering about the head with foil and gold leaf; while a long curved stick, extending backward from each 
yoke as far as the carriage, was painted in stripes of blue and yellow, and adorned with pendent tassels of coloured worsted. Both animals wore their charm against the Evil Eye; and the whole equipage was sufficiently wellappointed to have done honour to the harem of a Pasha, while the bright dark eyes and delicate hands of its occupants would have been an equal triumph for his taste. But at the first glance you saw that the carriage was not that of a Turk, for the painted hoops were plainly covered by a white awning, the symbol of the raz̈ah. The haughty Osmanli has reserved to himself the privilege of scating his wives beneath draperies of crimson, blue, or purple, fringed with gold; while the Armenian, the Greek, and the Jew, when making use of this popular conveyance, are obliged to content themselves with a simple awning of white linen. Here galloped a reckless Greek, urging his good hack to the top of its speed; there moved along a stately Turk, with the hand of his groom resting on the flank of his well-fed horse, and his pipe-bearer walking five paces behind him. Now it was a party of Franks, booted, spurred, and looking in silent scorn upon the incongruous trappings of the natives, and now a group of foot-passengers, walking at a pace which I never saw equalled in England.

As we approached Balouclè, the features of 
the scene became still more striking. The low wall that skirted the road was covered with Turkish women, squatted upon their rugs and carpets, with the arabas in which they had travelled ranged along behind them. Seridjhes were walking droves of horses to and fro, and waiting for customers to hire them ; travelling merchants were retailing yahourt and mohalibè to the hungry and the weary; Bulgarians were playing their awkward antics to attract the attention of the idle, and the piastres of the profuse; and the halt and the blind were seated by the wayside, to invoke the paras of the charitable. Parties of Persians, with large white turbans, silken robes, and eyes as black as midnight, were walking their well-trained horses through the crowd; and a detachment of the Irregular Troops, with their jester at their head, in a cap made of sheep-skin, adorned with three fox-tails, and a vest of undressed leather, drove back the people on either side, as they made their way through the throng with a sort of short run. They had precisely the appearance of banditti, each being dressed and armed according to his own means or fancy; while their huge mustachioes, and the elf locks that escaped from beneath their turbans, added to the ferocious character of their aspect.

The plain on which the Church is situated is thickly wooded in its immediate neighbourhood, 
and on this occasion was covered with a dense crowd of merry human beings. The same amusements as I have described at the Armenian festival were in full career; but the heavy meaningless dance of the Champs des Morts was here exchanged for the graceful romaïka, which was going forward in every direction.

For every other female whom I saw on the ground, I remarked at least a hundred and fifty Turkish women; and the astonishment excited by the appearance of the Greek lady by whom I was accompanied, and myself among these latter, was most amusing. As the greater number of then had never before seen a Frank lady on horseback, they concluded that we had each lost a leg; and the "Mashallahs!" with which they contemplated our gaiety were innumerable. But as a Turkish woman never scruples to address a stranger in the street; and as our being actually crippled was a matter of uncertainty; they were resolved to satisfy their mirds on this very important point; and several of them accordingly addressed themselves to the gentlemen of our party, in order to resolve the doubt; exclaiming with an energy worthy of the occasion: "For the love of God, tell us if your wives have lost a leg, or not!"

When they had been assured to the contrary, their next conclusion was still more amusing. It was clear that none but rope-dancers could 
balance themselves upon the back of a horse without having one leg on either side of the saddle-ergo, we were collectively, ladies and gentlemen, the identical party of rope-dancers, whom the Sultan had engaged for the marriage festivities of his Imperial daughter: and so perfectly convinced were they of their own sagacity on this second occasion, that I am only surprised that they had sufficient discretion to refrain from requesting us to give them a specimen of our abilities.

The Church of Balouclè stands in the centre of an enclosed court, within which are also situated the houses of the priests. A handsome flight of stone steps leads downward to the portal ; and, as you cross the threshold, the interior of the edifice produces on you the effect of something that has sprung into existence at the touch of an enchanter's wand. It looks as though it were built of porcelain, all is so fresh and so glittering. It is entirely lined with white and gold, and the paint upon the walls is so highly varnished, that you can scarcely distinguish it from the polished marble that composes the screen of the sanctuary; the latticed gallery of the women is fancifully decorated and gilt; and the elegant pulpit is shaped like an inverted minaret.

But the principal attraction of the Church of Balouclè, and that which lends to it its distin- 
guishing character of sanctity, is the Holy Well, dedicated to the Virgin, which, on the occasion of all high festivals, is opened for the benefit and edification of the pious. Situated in a vault immediately beneath the chancel, protected by a balustrade of marble, and lighted by the lamp that is constantly burning before the shrine of the Madonna, rises the spring whose holy and healing qualities are matter of devout belief with the Greeks ; and in which the lower orders of the people gravely assert that fish are to be seen swimming about, cooked on one side and crude on the other.

This somewhat extraordinary circumstance is accounted for by a variety of legends; the most comprehensible of the whole being that which affirms that, some holy man or woman having been refused food on this very spot, when on a pilgrimage to a shrine of the Virgin, situated in the neighbourhood, the well-disposed fish, whose pious self-immolation has been thus immortalised, sprang from the waters of the spring, and flung themselves upon the heated ashes of the fire, whereon the churlish host, who refused help to the weary and wayworn pilgrims, had just prepared his own meal. How the travellers were induced to refrain from the savoury repast; and how the fish contrived to return to the stream after being well cooked on one side, the legend sayeth not; and those who 
are inclined to doubt the fact of their present existence had better make a descent into the vault on the occasion of an Easter festival; and, should they still continue sceptical, after the scene which they will then and there witness, nothing that I can say will awaken their faith.

After having duly flung a few piastres upon the salver held by the priest who guarded the door ; and protected on either side by a gentleman, to secure me from the pressure of the crowd, I commenced my slippery descent into the subterranean chapel. The stone steps were running with water, spilt by the eager motions of those who were bearing it away; nor was this all, for, as they handed it to each other over the heads of such as chanced to obstruct their passage, an occasional shower fell upon us from above, whose holiness by no means sufficed to counteract its chill.

When I gained the chapel, and paused to take breath, a most singular scene presented itself. The narrow space was cumbered with individuals, who were shouting, struggling, and even fighting their way, to the margin of the Well : an image of the Virgin tricked out in gold and embroidery, before which burned the lamp that lit up the subterranean, gleamed out in vain from a niche opposite to the spring: the very piety of her votaries had induced them to turn 
their backs upon her; and I believe that mine was the only eye which rested upon her altar.

Some, who had succeeded in filling the vessels which they had brought with them, were standing bare-headed, throwing the cold stream over their shaven crowns: others, who had suffered from lameness, were emptying their earthen jars upon their feet ; some were pouring it down their chests, and others again down their throats.

By the strenuous endeavours of my friends, and the assistance of a sickly-looking priest who was collecting paras among the crowd, I succeeded in obtaining a draught of the water ; and, whether it arose from the stream having been thickened by the dipping in of so many vessels, or that the half fried fish imparted to it a disagreeable flavour of the charcoal ashes; or, again, that it was really and simply of very indifferent quality, I cannot take upon me to decide; while I am quite competent to declare that $I$ never swallowed a more unsatisfactory beverage, and that nothing less than. a very painful thirst would have induced me to venture upon a second trial.

On escaping from the subterranean, (and it was really an escape)! I went to examine the machine which in all the principalGreek churches acts as the substitute for a bell, whose use is not permitted by the Turks. It is a very in- 
artificial instrument, being merely a bar of iron resting lightly between two perpendicular pieces of timber, which, on being struck with a short bar of cypress-wood, emits a clear ringing sound, that may be heard to a considerable distance. In the smaller churches two sticks are beaten together, but this signal avails only when the congregation is nestled near the walls of the temple.

Having secured the water that they had taken so much trouble to obtain, the enthusiastic and light-hearted Greeks were pouring out of the chapel as we returned; and ere we could mount our horses many of them had already joined the dancers, and were engaged in winding through the graceful mazes of the romaïka, while others were busied in filling their chibouks in the neighbourhood of the coffee-tents.

A mass of heavy vapours, rising up against the wind, and arraying themselves like a host about to do battle, warned us not to linger long at so considerable a distance from home; and, profiting by the intimation of a coming storm, we started off at a gallop, to the increased astonishment of the 'Turkish women, who were still clustering like bees upon the wall. But our speed availed us nothing: we had not cleared the hills above Kahaitchana when the enemy was upon us; and a tempest of blended hail, rain, and wind bore 
us company for the remainder of the journey; and thus we were fairly drenched ere we reached Pera, notwithstanding our offerings at the shrine of the Virgin, and our pilgrimage to the Holy Well. 


\section{CHAPTER XXV.}

Figurative Gratitude of the Seraskier Paslıa - Eastern HyperboleReminiscences of Past Years-A Vision Realized-Strong Contrasts - The Marriage Fêtes - Popular Excitement - Crowded StreetsThe Auspicious Day-Extravagant Expectations-The Great Cemetery - Dolma Batchè - The Grand Armoury - Turkish Women Tents of the Pashas-The Bosphorus - Preparations-InvocationThe Illuminated Bosphorus- $A$ Stretch of Fancy-A Painful Recollection - Natural Beauties of the Bosphorus - The Grave-Yard Evening Amusements-Well Conducted Population.

IN a letter of thanks recently addressed by the Seraskier Pasha to the Sultan, in acknowledgment of some honour conferred upon him by his Imperial Master, he exclaims in an affected burst of enthusiastic gratitude :- “ Your Sublime favour has been as a southern sun piercing even to the remote corner of my insignificance. Had I all the forest boughs of the Universe for pens, and the condensed stars of Heaven for a page whereon to inscribe your bounties, I should still lack both space and means to record them!"

Even in this style should he or she who undertakes to become their chronicler, shape the 
periods in which are detailed the marriage festivities of the Princess Mihirmàh. The pen should be tipped with diamond-dust, and the paper powdered with seed-pearl. All the hyperboles of the Arabian story-tellers should be heaped together, as the colours of the rainbow are piled upon the clouds which pillow the setting sun; and, as the gorgeous tail of the peacock serves to withdraw the eye from its coarse and ungainly feet, so should the glowing sentences that dilate on the glories of the show, veil from the vision of the reader the paltry details that would tend to dissolve the enchantment.

How often have I hung entranced over the sparkling pages of the "Hundred and One Nights." How little did I ever expect to see them brought into action. When a mere girl, I remember once to have laid the volume on my knees; and, with my head pillowed on my hand, and my eyes closed, to have attempted to bring clearly before my mental vision the Caravan of the Merchand Abdullah, when he departed in search of the Valley of Diamonds.

Years have since passed over me, and that gorgeous description is no longer a mere dream. I have looked upon its realization-I have seen the flashing of the jewels in the sunshine - the prancing of the steeds impatient of a rider-the rolling of the fifty chariots - the gathering of 
the throng of princes - the eunuchs and the horsemen - winding their way over hill and through valley, under a sky of turquoise, along the bank of a clear stream; and within sight of a sea whose shore was studded with palaces, and upon whose blue bosom a fleet of stately ships were riding at anchor within an arrow's flight of land.

But I have also seen more than this. I have seen not only the machinery at work, but the wheels that worked it; not only the brilliant effect, but the combination of paltry means used to produce it - the blending of the magnificent and the mesquin - a thousand minute details, unimportant in themselves, and yet operating so powerfully on the imagination, that they clipped the wings of Fancy, and wrung the wand from the grasp of the Enchanter.

There is no consistency, no keeping, in Oriental splendour. The Pasha, with the diamond on his breast, is generally attended by a running footman who is slip-shod; and the Sultana, whose araba is veiled by a covering of crimson and gold, not infrequently figures in pantaloons of furniture chintz, and an antery of printed cotton. The same startling contrasts meet you at every step : and tourists and historians pass them over. because they destroy the continuity of their narrations, and the rounding of their periods; and yet they are as characteristic of 
the people as the chibouk or the turban, and therefore equally worthy of record.

The Fêtes were to continue for eight days the diamond was to be shivered into fragments, and thus divided into many portions without sacrificing its lustre. All the population of Constantinople was in a ferment - the charshees had yielded up their glittering store of gold and silver stuffs-the diamond-merchants had exhausted themselves in elegant conceits - the confectioners had realized the fabled garden of enchantment visited by Aladdin in his search for the magic lamp, and the candied fruits peeped from amid their sugary cases, like masses of precious ore, and clusters of jewels-the silkbazar of Broussa was a waste-the environs of Pera resembled a scattered camp - the heights around the valley of Dolma Batchè were guarded by mounted troops-provisions of every description trebled their price: and one vessel, laden with a hundred and fifty thousand fowls for the market of Constantinople, which arrived from the Archipelago, was secured for the exclusive use of the Sultan's kitchen.

Pashas were daily pouring in from the provinces-tribute was flung into the yawning coffers of the state-audiences of congratulation kept the Imperial Palace in a constant whirl-and the streets of the city were thronged with a motley crowd, either invited thither by

voL. I.

G G 
the authorities, or attracted by the hope of profit. Bulgarians, in parties of three or four, impeded the progress of every respectable passenger who would fain have threaded his way among them unmolested; and by dint of stunning him with their discordant instruments, and intruding themselves upon his path to exhibit their coarse and ungainly dances, wrung from him by their sturdy perseverance a donation whose inıpulse was certainly not one of eharity. Bohemian gipsies, some of them so lovely that they seemed formed to command the prosperity which they subtly promised to others, were bestowing palaces and power on every side at the slender price of a few paras. Arabian tumblers, turned loose for the first time in the streets of a great capital, and appearing scarcely able to keep their feet upon the solid earth, jostled you at every corner. Persian rope-daneers stalked gravely and solemnly along, with large white turbans, and flowing robes. Bedouin jugglers were grouped in coffee-shops and smoking-booths, awaiting the moment when their services would be required; and bewildering the sober brains of the surrounding Turks with loud vauntings of the feats with which they proposed to delight his Sublime Highness, and to astonish his people. Altogether, Constantinople resembled a human kaleidoscope, whose forms and features varied at every turn; and even those who, like myself, 
had no immediate interest in the festival, caught a portion of the popular exitement, and became anxious for the period of its celebration.

At length, the auspicious morning dawned which the Court Astrologer had declared to herald happiness to the Princess ; and all Stamboul had crossed the Bosphorus with the rising sun to share in the Imperial festivities.

Long before mid-day Pera also was a desert : the stream of life had flowed in one sole direction, and every avenue leading to Dolma Batchè was thronged with human beings, anxious and excited, and yet scarcely knowing what they anticipated. The marriage festival had been the one engrossing subject of discourse and speculation for so many months - such extravagant suggestions had been hazarded, and such wild assertions had been made, that the imagination of the crowd had run riot; and, had the fountains poured forth liquid ore, and the heavens themselves rained diamond-dust, I am not sure that such events would have caused any extraordinary manifestation of astonishment, from the mass of spectators who had clustered themselves like bees in the neighbourhoor of the palace.

The Great Cemetery looked as though every grave had given up its dead; there was scarcely space to pass among the crowd which thronged it. Dancing, smoking, and gambling for sugarG G 2 
plums, (the only stake that a Turk ever hazards on a game of chance) divided the attention of the loiterers, with swings, round-abouts, and mohalibè merchants. Pillauf and kibaubs were preparing in every direction for the refreshment of the hungry; and tinted and perfumed sherbets, carefully guarded from the sun, were whiling in their turn the weary and the warm to pause on their onward path, and indulge in their tempting freshness.

The tents were flaunting their bright colours in the sunshine; the smoking booths were filled with guests ; the little wooden kiosk on the edge of the height was unapproachable; the long line of wall surrounding the Artillery Barrack was, as usual on all festive occasions, covered with Turkish women; and the whole space beneath was instinct with life and motion.

From the point of the hill above the sea the land shoots sharply down into the valley of Dolma Batchè, clothed with fruit trees, whose perfumed blossoms, then in the height of their beauty, were emptying their tinted chalices. on the air. The roarl leading to the Palace is cut along the side of the declivity, forming on its upper edge a lofty ridge which was fringed throughout its whole length with tents; in the distance rose the Military College, spanning the crest of the hill like a diadem ; with the gilded and glittering crescent that crowns the dome of its mosque flashing 
in the sunshine. On the right hand the view was bounded by the dense forest of cypresses rising above the tombs of the Turkish cemetery, which swept darkly downwards to the Bosphorus that was laughing in its loveliness, and reflecting on its waveless bosom the lovely height of Scutari which hemmed in the landscape. And as the eye wandered onward along the channel, it took in the dusky shore of Asia, with its kiosk-crowned and forest-clad mountains; until the line was lost in the gradually failing purple, that blent itself at last with the horizon.

Immediately beneath the hill, and close upon the shore, stands the Palace of Dolma Batchè, with its walls of many tints, and its fantastic irregularity of outline; while behind its spacious gardens, sloping gently upward, and clothed with turf, rises a stretch of land which was now crowded with 'lurkish women. Nothing could be more picturesque than their appearance: the nature of the ground having enabled them to arrange themselves amphitheatrically, and from thence to command an uninterrupted view of the esplanade in front of the Grand Armoury, which is enclosed on its opposite side by a raised terrace, along whose edge were pitched the tents of the Pashas. There must have been at least five hundred women elustered together on that one small stretch of land; and in the distance it presented preciscly the appearance of 
a meadow covered with daisies, with here and there a corn-poppy flaunting in the midst; the white yashmacs and red umbrellas lending themselves readily to the illusion.

The tents of the Pashas were many of them very magnificent : the Grand Vèzir's was hung with crimson velvet, richly embroidered; while that of Achmet Pasha was lined with green satir, and fringed with gold; and the whole were richly carpeted, and surrounded by handsome sofas. 'The reception-marquee, in which the Sultan was to entertain a party of guests daily, was situated in the rear of those that I have just described: and the kitchen, ingeniously fitted up with stoves, dressers, and tables, hewn in the hill-side, was tenanted by five hundred cooks.

The Bosphorus was crowded with caïques, almost as countless as its ripple; and immediately in front of the Palace, and nearly in the centre of the stream, were anchored two rafts, supporting small fortified castles, whence the fireworks were to be displayed.

A survey of these different preparations proved to be the principal amusement of the day, as the rope-dancing on the Esplanade of the Armoury was not sufficiently attractive to detain any individual less indolent than a Turkish woman; and consequently, after having conpleted our tour of observation, we returned to 
Pera in order to repose ourselves, and to prepare for the magnificent spectacle that awaited us in the evening.

And now, ye Spirits of Fire, who guard the subterranean flames which are only suffered to flash forth at intervals from the crater of some fierce rolcano - Ye, whose brows are girt with rays of many-coloured radiance, whose loins are cinctured by the lightning, and whose garments are of the tint which hangs like a drapery over the cineritious remnants of a conflagrated city-Ye, who must have left your vapoury palaces, and bowed your flame-crowned heads upon your gleaming wings, in blighted pride to see your lordliest pageants overmatched-lend me a pen of fire, drawn from the pinion of your bravest sprite, and fashioned with an unwrought diamond; for thus only can I record the glorious scene that burst upon me, as, at the close of day, I stood upon a height above the channel, when a festive people had recorded their participation in the gladness of their Monarch, in characters of fire.

The moon rode high in Heaven, but her beam looked pale and sickly, as it faded before the brighter light with which men had made night glorious; while the stars seemed but fading sparks, that had been emitted by the stupendous line of fire girdling the Bosphorus-It was a spectacle of enchintment! 
Not an outline could be traced of any of the lordly piles which fringe the coast. The summit of the Asian shore was dimly perceptible, as it cut sharply against the clear deep blue of the horizon; but there was no intrusive object of mortal creation for the every day necessities of life, to recall the wandering fancy back to earth. Nothing can be conceived more beautiful than the whole scene. A range of palaces of the most fantastic forms, wrought in fire, and seeming to be poized upon the waves, along which they threw their gleaming shadows, stretched far as the eye could reach. Portals of variegated light-terraces of burnished gold, or of beaten silver - groves of forest trees, whose leaves were cmeralds-fruits, heaped in stately vases, each one a priceless gem-altars, upon which burnt flames of liquid metal - pavilions of crystal - and halls, lined with columns of sapphire, and lighted by domes of carbuncles, were among the objects that appeared to have sprung up from the depths of the ocean, and to be now riding upon its bosom.

The sensation which this gorgeous scene produced upon me, for the first few moments, was almost painful. I deemed myself thralled-I doubted my own identity - I almost expected the earth to fail beneath my feet, for earth had no share in the spectacle on which I looked - I saw boats passing and repassing over a lake of 
molten silver-I saw palaces of fire based upon its surface, and heaving with its undulationsa marine monster, whose eyes were dazzling, and whose nostrils vomited forth flames that shot high into the air, wound its slow way among the gliding barks, and none heeded its vicinity-I beheld huge dark masses covered with stars of light, which were reflected in the stream beneath, looking like rocky craters that would shortly burst, and cast forth the imprisoned fires carriages and horses, guided by spectral hands, followed over the same cold clear surface - and suddenly, with a hissing sound which startled me from my reverie; and a burst of light almost blinding, up sprang a cluster of ficry serpents into the pure ether, mocking the pale moon with their transient brilliancy, and then falling back in starry showers.

The dream of fancy was dispelled at once:A handful of rockets sufficed to arouse me from one of the wildest visions in which $I$ ever remember to have indulged-for I no sooner saw them run shimmering along the sky, than I sickened at the memory of the frightful catastrophe which attended their preparation; when eighty-four miserable human beings fell victims to the explosion of the powder-room of the manufactory. My enthusiasm was at an end : but my admiration of the magnificent scene, amid which I stood, continued unabated; the channel of the 
Bosphorus, beautiful under all circumstances, and at all times, offered facilities, and enhanced effects, in an exhibition like that on which I looked, that cannot probably be exceeded in the world; and I felt at once that, even had man done less, nature would still have made the pageant peerless.

We at length turned reluctantly away from the City of Fire on which we had been so long. looking; and, threading among the tents that occupied the crest of the hill, we passed out through the fair of the Great Cemetery. Every booth was thronged. In one, a set of Fantoccini were performing their miniature drama; in another, an Improvvisatore was regaling a circle of listeners with a gesticulation and volubility which appeared to excite great admiration in his auditors; while in a third, a trio of Bohemian ministrels, squatted upon a mat, were accompanying their wild recitative by a few chords struck almost at random upon their mandolins.

In the distance, a wreath of lamps defined the outline of the Military College ; while lower in the valley gleamed out the costly chandeliers which lit up the tents of the Pashas. 'The hills were sprinkled over with lights; the terrace at the extremity of the palace was a wall of fire; and the scene was all life and gladness. Crowds thronged the narrow road; but not a sound of 
discord, not a word uttered in menace or in defiance, escaped from the lips of a single individual; all were tranquil, orderly, and well conducted; the sole aim of each was amusement; and this great eastern mob, amounting to between forty and fifty thousand persons, collected together from all the surrounding country, from the heart of a great city, and from the shores of two different quarters of the earth, appeared to act from one common impulse, and to have one common interest.

It is questionable whether such a fact as this could be recorded of any other country. 


\section{CHAPTER XXVI.}

Repetition - The Esplanade - The Kiosk and the Pavilion - A Short Cut-Dense Crowd-A Friend at Court-Curious Coup d'OEil-The Arena - The Orchestra - First Act of the Comedy - Disgusting Exhibition-The Birth of the Ballet - Dancing Boys - Second Act of the Drama-Irisult to the Turkish Women-The Provost Marshal -Yusuf Pasha, the Traitor-Clemency of the Sultan-Forbearance of an Oriental Mob-Renewal of the Ballet-Last Act of the Drama - Theatrical Decorations-Watch-dogs and Chinese-Procession of the Trades - Frank Merchants - Thieves and Judges - Bedouin Tumblers-Fonduess of the Pashas for Dancing - The Wise Men of the East.

It were worse than idle to follow the daily progress of the Fêtes. It were but to weary the reader with repetitions, or to delude him with fictions; for the same actors being engaged during the whole of the festival, only varied their exhibitions sufficiently to emancipate themselves from the reproach of actual repetition. So monotonous, indeed, did I find the second representation I was induced to witness, that I never ventured upon a third.

I have already mentioned that the Esplanade of the Grand Armoury had been selected as one of the spots upon which the sports were to take place; but I learnt from an individual who had possessed himself of the important secret, that the principal performers were to exhibit on a 
piece of land situated between the palace walls, and the kiosk in which the Pashas did the honours to the dinner-guests of the Sultan, after the termination of their repast; while a garden Pavilion, whose windows opened upon this space, was to be tenanted by his Sublime Highness, his Imperial daughters, the Sultana, their mother, and half a dozen of the most favoured ladies of the harem, who, from the painted lattices, could look forth upon the scene.

This arrangement sufficiently attested the superiority of the situation; and, accordingly, avoiding the crowd of the Champs des Morts, and the thronged descent into the valley, we drove across the hills beyond the Military College; and then, skirting the height above Dolma Batchè, suddenly descended almost under the walls of the Palace. But the chosen spot was surrounded by guards, and the crowd were clustered densely in their rear; so densely, indeed, that the arabadjhe declared our further progress to be altogether impracticable.

From this dilemma we were fortunately extricated by an officer of Achmet Pasha's household; who, perceiving the difficulty, hastened to remove it, which he effected in no very gentle manner by striking the individuals who impeded our passage right and left with the flat of his sword, until he established us immediately behind the line of military. 
The performances had not yet commenced, and I had consequently time to contemplate the animated scene before me. On my right was the kiosk, whose wide casements were crowded with Pashas; on my left the Garden Pavilion, which had the honour of screening from the gaze of the vulgar the Brother of the Sun and his train of attendant beauties; behind me rose the hill whose summit was covered with the tents of the Imperial suite, and whose rise was occupied by a crowd of Turkish females; and before me stretched the Bosphorus. A small opening, leading down from the arena towards the shore, was occupied by a detachment of military : and beneath the windows of the kiosk, mats had been spread for about a hundred women, who were comfortably established under the long shadows of the building.

At the other extremity of the circle, thirteen Jews, seated crescent-wise, were playing upon tambourines; while as many more, squatted in their rear, were each beating upon a sort of coarse drum, whose only attribute was noise; and the time to be observed by the musicians was regulated by an individual, with a venerable white beard and a staff of office. This headsplitting orchestra continued to accompany the whole performance, with very slight intervals of rest; and was quite in keeping with the remainder of the exhibition. 
Not the slightest effort had been made to level the piece of land thus converted into a temporary theatre, and which was stony and uneven to a degree that must have disconcerted any individuals less philosophical than those who were to exhibit their histrionic and terpsichorean talents before the Ottoman Emperor and his August Court. In fact, the whole of the scenic preparations were conducted in so primitive a manner that you saw at once no deceit was intended, and that, if you suffered yourself to be led away by the incidents of the drama, you would not be deluded thereto by any effort of the actors.

The first arrival upon the scene was that of four ragged personages, apparently intended to represent the street porters who ply for hire about the quays and markets; and these interesting individuals sustained a long and animated conversation, setting forth the dull condition of the Queen of Cities, in which neither feast nor festival had been held since the Baïram. 'Their lamentations at length attracted the attention of a fifth loiterer of the same class, who, joining the group, gave a new tone to the subject by announcing the approaching marriage of the High and Peerless Princess Mihirmàh-the daughter of His Sublime Highness Mahmoud the Powerful, the Emperor of the East, and Conqueror of the World! 
The intelligence was received with enthusiasm, and the new comer was encouraged to proceed with his narration; in which he accordingly set forth not only the beauties and virtues of the Imperial Bride, and the high and endearing qualities of her affianced husband, but also gave a catalogue raisonné of all the sports and ceremonies which were to be observed on the happy occasion of her nuptials; and it is only fair to believe that he did so with some address, as a murmur of admiration ran through the crowd who were devouring his discourse.

After asserting that the whole universe had been taxed to produce novelties worthy of the illustrious event, he proposed to exhibit to his companions an ingenious machine that had been imported from Europe, and which was to be exhibited by a friend of his own. Hereupon, a sort of buffoon was introduced, attended by two men, who fixed a swing with a lattice seat between two slight wooden frames, which they were obliged to support during the remainder of the scene.

One by one, the respectable worthies whom I have attempted to describe were seated in the swing, and rocked gently backwards and forwards by the proprietor of the show; and during this time an old Jew, with a long white beard and tattered garments, followed by a deformed and hideous dwarf, joined himself to the party, 
but at a sufficient distance to indicate that he was conscious of his unworthiness to intrude upon their notice.

A mischievous whim suddenly prompted the hilarious Mussulmauns to make the quailing dwarf a party in their pastime, and they accordingly placed him in the swing, and amused themselves for a time with his abortive attempts to escape ; but, wearying of the jest, they agreed to replace him by his master; and, despite the prayers and terror of the hoary Jew, they compelled him to occupy the crazy seat, which, failing beneath his weight, precipitated him to the ground, where, falling upon his head, he remained apparently lifeless.

At this period of the performance, half a score of the members of the orchestra left their places, and walked demurely out of the ring, in order to swell the crowd which shortly afterwards advanced to raise the body of the murdered man, and convey him away to burial.

Nothing can be conceived more disgusting than the scene that followed; all the actors being actually Jews, selected from the very dregs of the people, and compelled to exhibit the degradation of their social state for the amusement of their task-masters. A wretched bier, borne by four men, was brought forward, on which the supposed corpse was flung with a haste and indecency betokening strong alarm ;

VOL. I.

$11 \mathrm{H}$ 
and it was about to disappear with its loathsome freight, when its passage was obstructed by a party of police, who, occupying the centre of the path along which it was passing, and remaining erect on its approach, were supposed to awaken in the bosoms of the bearers one of the strongest superstitions of the Jews of Turkey ; who, when they are carrying a body to the grave that is met by a Christian or a Mahommedan who refuses to bend down and pass under the bier, consider the corpse so contaminated by the contact as to be without the pale of salvation; and, setting down the body under this impression on the spot where the encounter has taken place, they abandon it to the tender mercies of the local authorities.

This wretched and revolting superstition was enacted by the degraded wretches who were hired on the present occasion to expose the abjectness of their people, with all the painful exactness which could delude the spectator into the belief that he beheld a scene of actual and unpremeditated horror. A distracted wife tore off her turban, and plucked out handfuls of her dishevelled hair; the body was rolled over into the dust : a scuffle ensued between the Jewish rabble and the armed kavasses, in which a few blows were given that appeared to fall more heavily than was altogether necessary to the effect of the scene ; and the $\mathrm{J}_{\mathrm{cw}}$, recovering from 
his trance amid the shouting and yelling of the combatants, was borne off in triumph by his tribe, with a wild chorus that terminated the first act of the drama!

At intervals, the disgust which this hateful exhibition tended to excite in my bosom was relieved by the arrival of some tardy Pasha, attended by a train of domestics; who, entering the arena by the passage to which I have already alluded as opening from the shoreward side of the enclosure, guided his richly caparisoned steed, whose housings were bright with gems and embroidery, through the motley throng of actors; while his diamond star glittered in the sunshine, and his gold-wrought sword-belt and jewelled weapon-hilt flashed back the light that glanced upon them.

My pen wearies of its office, as I pursue the detail of the morning's performance; but I compel myself to the task, in order to convey to my readers an accurate idea of the Turkish drama-for this coarse, revolting, and aimless exhibition, whose description I have commenced, is the highest effort that the histrionic art has yet made in Turkey; and I am bound to add that the effect which it produced upon the spectators was one of unequivocal gratification.

The retreat of the Jewish party was succeeded by the arrival of a group of ballet dancers, con- 
sisting of about a score of youths from fourteen to twenty years of age, dressed in a rich costume of satin, fringed and ribbed with gold, varying in colour, according to the fancy of the wearer. They all wore their own long hair, curled in ringlets, and floating about their shoulders ; and their appearance was so extremely disagreeable, notwithstanding the splendour of their costume, that I was surprised to learn that they all belonged to the Sultan, or to different wealthy Pashas, who take so much delight in seeing them dance as to keep several constantly in their pay.

As I had been assured that the whole of the exhibition remained precisely similar to the scenic amusements of the ancient Romans, I contemplated it with more patience than I should otherwise have been able to exert: for I soon discovered that the dancing was quite upon a par with the dramatic portion of the entertainment. If that upon which I now looked were indeed the germ whence sprang the most graceful and the most elegant of all the movements of which the human form is susceptibleif this were indeed the birth of the Ballet-then is it a fair child that may truly blush for its parentage: for the exhibition was coarse, monotonous, and wearisome, nor did it possess one redeeming attribute. An unceasing circuit of the enclosure-a wreathing of arms and hand- 
kerchiefs-an affeeted inclination of the head first to the one side, and then to the other-a beating of feet upon the earth, and a succession of prostrations before the Pashas, appeared to be the extent of talent of which the dancers were capable; and the only variation that I was able to discover was an increase of speed, which rendered the heavy movements of the exhibitors only the more conspicuous. The very appearance, moreover, of this party of petticoated and long-haired youths was revolting to my English ideas: and, despite the acclamations with which they were liberally greeted, I felt glad when they made their parting obeisance, and gave place to the second series of performers.

A Turk, fèzed and coated, next entered upon the scene-a sort of Oriental Jacques, melancholy and gentleman-like, who told a tale of blighted love, and consequent sadness; at whose termination he was accosted by the buffoon, who in his turn delivered a panegyric on the loveliness of the veiled beauties of Stamboul, which however failed in its effect upon the slighted suitor; who, with sundry contortions, and wringings of the hands, professed his inability ever to love again.

The buffoon, resolved, as it appeared, to make trial of his constancy; or outraged at the affectation of so anti-'Turkish a display of sensibility; 
shortly withdrew; and returned accompanied by three of the Ballet dancers, disguised as females, and wearing the yashmac and the feridjhe. Of course, curiosity succeeded to indifference, and passion to curiosity; and a scene of love-making ensued, that consisted of attempts to induce the ladies to unveil; experiments with the swing, which occasionally broke down to the great amusement of the spectators ; and energetic asseverations on the one part and the other.

During the scene, the principal dancer, who personated the attractive fair-one, displayed considerable talent in his part; the feridjhe was thrown aside; and those Franks who were present, and who could not necessarily hope to gain even a glimpse of a Turkish female in the costume of the harem, had here an excellent opportunity of forming an idea of their appearance; and not only of their appearance, but of their manners also, for the resemblance was perfect; and, to render the ridicule still more complete, the dress was that of the last Palace adoption - the antery and trowsers, wedded to the wadded silk jacket and gigot sleeves!

In the course of the performance, he danced the dance of the harem, with a degree of skill that few of the female dancers ever attain; and which elicited great applause from the 
audience; and, had the exhibition ended here, it would have been rather absurd than revolting; but the jealous Musselmauns, who veil the casements of their harems with lattices, and the faces of their women with yashmacs, sat not only quietly but admiringly by, while all, and probably more than all, the secrets of the interior were laid bare, and caricatured for the amusement of the vulgar. There could not have been a high-minded 'Turkish woman present, who did not blush at least as deeply for her husband as for herself; and not a pure-hearted female of any nation, who did not feel more contempt for the instigators of the insult than for its objects.

Not one of the least extraordinary portions of the day's performances was enacted by a young Pasha, recently promoted to that distinguished rank, with the additional titles of General, and Provost-Marshal of the Ottoman armies. This very heavy and coarse-looking individual, who was formerly Commandant. of the Military College in its days of neglect and utter uselessness, is the son of Yusuf Pasha, the treacherous Chicf who sold Varna to the Russians, and escaped into the Northern States, where he remained secure, until the kind-hearted Nicholas had wrung his pardon from the betrayed Sultan; who in his plenitude of mercy not only forgave the crime of his false servant, but 
rewarded his affected penitence with the $\mathrm{Pa}$ shalik of Belgrade, which he now enjoys.

Mustapha Pasha, his son, figured on the occasion of the Fêtes with a diamond star upon his breast, and grasping a whip bound with gold wire, and furnished with a long lash, which helaid about the heads and shoulders of the mob with a most lavish hand, whenever they advanced an inch or two beyond their allotted boundary. I confess that I could not help smiling as I pictured to myself the reception which His Highness Mustapha Pasha, General of Brigade, and Provost Marshal of the Ottoman Armies, would have received from a sturdy English mob, when they felt his long whip among them! I suspect that his labours would have been brief, and his office not altogether a safe one.

Could I have disengaged my carriage from the crowd, I should at once have retired, perfectly satisfied with the specimen I had obtained of the Turkish taste in theatricals; but the arabas were standing four decp, and pressed upon from behind by a dense mob; and I was consequently compelled to remain a patient spectator of the whole performance. Intrigues with Greek serving-men, domestic quarrels ending in blows, and similarly well-conceived incidents, filled up the canvass, until the end of the second act, when a fresh set of ballet dancers, amounting 
to. nearly one hundred, and clad in the beautiful old Greek dress, entered, and made their bow to the Pashas.

During their performance, which was similar to that of the first party, although less gracefully executed, a new feature was added to the exhibition. An attempt at side scenes was evident, though I confess that for the first few minutes I was at a loss to imagine the intention of the very primitive machinery that was introduced. A couple of frames, similar to those on which linen is dried in England, were placed on a line about twenty feet apart, while; in the centre, a low railing of about six feet in length divided the distance. A poor old wretch, with a rope about his neck, was then tied to each frame, and made to squat down upon his hands and knees, to represent a watch-dog; and some green almonds were scattered about him for his food.

These miserable individuals, whose hired and voluntary degradation made me heart-sick, were both of them old men, whose beards were grey, and whose age should have exempted them from such an office as their necessities had induced them to fulfil. Beside these were placed two youths dressed as Chinese, with long braids hanging down their backs, and feather fans in their hands; not very unlike the figures which adorn the old china in the cabinet of an anti- 
quary. Next came forward a procession composed of all the trades of Constantinople, from the Jew who vends fried fish at the corners of the streets, to the Frank merchant, who, when he closes his office, becomes one of the "Exclusives" of Pera.

Of course, the Frank was very roughly handled. His hat was struck off, and made a football for all the raganuffins by whom he was surrounded; and the comments which were uttered alike upon his costume and his country were by no means courteous or conciliatory. But it could scarcely be expected that more delicacy would be observed towards a Frank than had been shown to the women of the country; and, this specimen of bad taste apart, the procession was the best point of the performance; as the individuals who composed it appeared to have been principally " taken in the fact," and forced upon the scene; thus affording faithful rather than flattering representations of their several callings.

When the procession moved off, the serious business of the drama was resumed; the three females re-entered on the scene, accompanied by their mother, and a Greek serving-man, laden with their parasols and essence-bottles; and followed by two thieves, who concealed themselves behind the Chinese statues, for swch I found that the two quaint figures who 
had so quietly walked to their places were intended to represent. After a vast deal of absurd grimace and buffoonery, rugs were spread in front of the low railing, and the four females and the Greek servant seated themselves, to listen to a tale told by the old woman.

While they were thus engaged, the melancholy Jacques of the previous act stole upon their privacy, when an absurd exhibition of screaming and fainting took place; during which the two thieves contrived, without any attempt at selfconcealment, to possess themselves of the cachemires and handkerchiefs of the ladies, and, moving a few paces apart, they began to divide the spoil; when the buffoon, in his turn, prowling about the neighbourhood, discovered the theft, and, raising a hue and cry, at which the dogs were let loose by the party, hastened during the confusion to seize upon the booty of the robbers. The outcry attracted the attention of the Cadi, who entered, accompanied by his attendants, to ascertain the cause of the tumult ; when the ladies, with tears and shrieks, declared the amount of their losses, and demanded justice.

Of course the good taste which had made a jest of the feelings of their allies, and the morals of their women, would not permit the Turkish comedians to spare their judges; and accordingly the Cadi was a huge caricature of hu- 
manity, with spectacles as large as saucers, and a beard of sheep skin. A hurried trial ensued, in which, while the Cadi was ogling the females, the buffoon was making himself merry at the expense of the Cadi; the executioner with his bastinado, and the clerk with his ink-horn and parchment, were both forthcoming; and the drama ended by the capture of the thieves, and the restoration of the stolen property!

A confused dance, accompanied by the wild, shrill chanting of the dancers, which I can compare to nothing but the orgies of a troop of Bacchantes, succeeded the departure of the actors, and the whole arena appeared in motion. The drums and tambourines gave out their loudest discord; gold and silver glittered in the sunshine; arms were tossed in the air; the long tresses of the performers floated on the wind; and I was delighted when the appearance of a troop of Bedouin Arabs, summoned to Stamboul expressly for the occasion, possessed themselves of the open space to exhibit their feats of strength and address. 'They were magnificently attired in coloured satins, and formed a very curious group; but their accomplishments would scarcely have secured for them an engagement in a respectable English booth. It was altogether pitiable.

When I at length contrived to escape from the crowd, I left a party of the dancing boys 
performing their evolutions in the Kiosk of the Pashas. Their Highnesses had not yet had a surfeit of the senseless pastime; and the youths were reaping a golden harvest.

The days are gone by in which people were wont to talk of the "Wise Men of the East." 


\section{CHAPTER XXVII.}

Succession of Banquets-The Chëik Islam and the Clergy-Sectarian Prejudices-The Military Staff - The Naval Chiefs - The Imperial Household-The Pashas-The Grand Vizier-Maguificent Procession-Night Scene on the Bosphorus - The Palace of the Seraskier Pasha-Palace of Azmè Sultane-Midıight Serenade-Pretty Truants-The Shore of Asia - Ambassadorial Banquet - War DanceBeautiful Effects of Light.

ONE of the most characteristic features of the marriage festivities was the succession of banquets given by the Sultan to the different high personages, belonging to, or connected with, his Empire.

The first day was sacred to the Clergy, and the procession was a most interesting one. At its head walked the Cheìk Islam, with the golden circlet about his brow, and his graceful robes of white cachemire falling around him in heavy folds; a party of the principal Imams followed. Then came the High Chief of the Turning Dervishes, with his lofty hat of white felt folded about with a shawl of the sacred green, and shrouded in his ample mantle. Other sects of Dervishes succeeded; and after 
them came Hadjis from the Holy Shrine of Mahomet-Emirs with their voluminous white turbans-and Fakirs from the far East. A short space behind advanced the Greck Patriarch, with his jewelled crown, and robes of embroidered satin ; supported by a group of prelates. Following close upon his steps, next moved forward the Armenian Archbishop, similarly attended, and gorgeously attired; and as he advanced, he made way for the Jewish Hahāmbachi, or Grand Rabbi, with his flowing beard and inlaid crosier; a throng of Rabbis were in his train; and altogether the scene was one of a most interesting character.

On the arrival of these holy men at the banquetting tent, a delicate difficulty presented itself. The heads of the Greek and Armenian churches resolutely refused to sit at table with, or to eat from the same dish as, their Israelitish companion; while the Jew, on his side, declared the utter impossibility of his partaking of the same food as that eaten by his Christian brethren. 'The stately Chèik Islam, meanwhile, was sitting by in uninterested silence; wondering, in the tolerance of his own heart and creed, why men serving the same God should not "dip with each other in the dish.".

The difficulty was at length surmounted; for, as the Jewish law did not permit the Hahāmbachi to partake of flesh that had not been 
slaughtered by one of his own tribe, there was nothing left for him but a dinner of cheese and salad, which was accordingly spread on a sidetable; while the scrupulous Christian prelates, who had refused the companionship of the representative of the ancient religion, seated themselves quietly on either side of the High Priest of Mahomet, and made an excellent dinner. The honours were done by four of the principal Pashas; and, at the close of the repast, the party adjourned to the kiosk to which I have already made reference, in order to enjoy the flight of the rockets, and the fairy wonders of the illuminated Bosphorus.

To the church succeeded the army; and on the morrow Achmet Pasha, and the principal Officers of the Staff, were the invited guests.

The magnificent shipping in the harbour next gave up its chiefs; and again Achmet Pasha, as temporary High Admiral, headed the board.

On the fourth day, all the members. of the Imperial Household were feasted in their turn; and, on the fifth, came the princely train of Pashas.

The Grand Vèzer rode first on a magnificent white Arabian, whose housings were wrought with gold and seed-pearl. His bridle-rein was richly worked with coloured silks; and his golden stirrups were finely chased. His sword-hilt blazed with diamonds: and the brilliant order 
that he wore upon his breast burnt in the sunlight; fifteen servants on foot surrounded his horse.

He was followed by the four newly-elected Vèzirs : the Oumouri-Mulkiènaziri, or Minister of the Interior; the Oumouri-Karidjiè-Naziri, or Minister of the Exterior; the Minister of Military Finance: and the Lord High Comptroller of the Mint; by the Seraskier Pasha, the Generallissimo of the Imperial Armies, the Grand Master of the Artillery, and a crowd of outdwelling Pashas, who had been summoned by the Sultan to assist at the festival.

I never witnessed a more magnificent or profuse display of diamonds, and embroidery; of proud steeds, and glittering parade. The crowd of running footmen - the trampling of impatient chargers-the clashing of jewelled weapons against the gilded stirrups - the noise, the hurry, and the glare, baffle all description; and when at length the princely train had disappeared within the tent, and the grooms were leading away the splendid animals, who, freed from the control of a rider, were rearing and prancing among the crowd, I felt like one suddenly awakened from a gorgeous dream, and had only a severe headache left, to convince me that I had really been a spectator of the splendid scene.

In the evening, well furred and cloaked, we voL. 1 . 
descended to the pier of Topp-hannè ; and having secured one of the large cainques that ply to the islands, we stepped on board; and, rowing out into the middle of the channel, contemplated at our ease the wonders which surrounded us.. From the centre of the stream, the whole mass of waters appeared to be girdled with fire; the shore was wrapt in darkness, and the edifices of light seemed to lift themselves almost to the clouds. I can conceive nothing finer of its kind; and we continued almost motionless where we had first paused, our caiique heaving gently upon the bosom of the blue waters; until a large flight of rockets gave us a momentary view of the surrounding shores; but, above all, of the surface of the channel.

If I had been surprised at the density of the crowd on shore, I was tenfold more so at the floating throng which had almost choaked up the passage of the Bosphorus. Every light and manageable craft that could be made available, was astir that night, from the caique of the Pasha, to the little, round, tub-like boat of the Archipelagon trader; while the countless white yashmacs of the women gleamed out in the light of the rockets like a dense ridge of surf, as you approached nearer to the edge of the shore; a circumstance which was readily accounted for by the fact that no Turkish female is allowed to walk the strects after eight o'clock 
at night, and that this was consequently their only method of witnessing the illuminations.

Having contemplated the general effect from a distance, we with some difficulty made our way through the caïques which were closely wedged together opposite the Palace of Dolma Batchè, just in time to escape one of the magnificent explosions produced by the Greek fires, that were blazing up out of the water in every direction, and which burst not five yards from our boat.

Of all the illuminations, that of the Seraskier Pasha, taken individually, was by far the most brilliant. The whole façade of the palace was one blaze of light; and, in lieu of the oil by which the lamps were filled in every other instance, he had fed the flame with some ardent spirit, which gave to it the fitful tint and the flashing brilliancy of diamonds. A magnificent screen in arabesques, on the opposite coast, at the small summer palace of Scutari, was the next most attractive object of the Bosphorus. But it is only as a whole that such a pageant should be judged; and all those who looked upon the one which I have attempted to describe, will doubtlessly concede that it was a spectacle of beauty which has probably never been exceeded.

We made our way slowly, but without much difficulty, along the European shore, until we reached the Palace of Azmè Sultane; but for 
a while after we had gained that point all further progress was impossible. There must have been many hundred caïques wedged together in front of her terrace, and not less than fifty of them contained musicians. We had intended to disembark at the palace steps, and to pay a visit to Nazip Hanoum, but were obliged to abandon the idea, as we became instantly aware that the thing was impracticable. We therefore remained quietly in our boat, under the bright light of the magnificent screen upon whose surface coloured lamps were intermixed with orange boughs and exotic flowers. The terrace was crowded; and I saw more than one light and fairy figure, that even the feridjhe failed wholly to conceal, which looked as though its owner should rather have been peering through the slender lattices, than from beneath the shade of a yashmac; but the occasion was so rife with excitement, and the roices from the caïques were so enticing, that doubtlessly more than one fair Dilaram and Leyla played truant that evening after the prescribed hour.

Having at length contrived to make our way through this crowd of worshippers, for such they must have been, we left the Palace far behind us in a few minutes, and escaped from the noise and even danger which were the present characteristics of its vicinity. Our sturdy boatmen, bending to their oars, soon brought us opposite 
to the dwelling of the bride, whose whole extent was bright with festooned fires; but my spirit had begun to weary with the perpetual glare, and I rejoiced when we struck out once more into the middle of the channel, and running under the shore of Asia, whose infrequent lights at this point of the stream rather relieved than pained the eye, left far behind us the clamorous merriment of the crowd. We had the moon high above us; the pale and placid moon, which had for many nights been mocked by a radiance more dazzling than her own; while the myriad stars that were twinkling their silver eyes as if in wonder at the scene beneath them, were reflected in the clear water as in a mirror. It was a heavenly night; and as we glided slowly along under the Asian mountains, the song of a hundred nightingales came to us from the groves and gardens of the coast.

The transition was extraordinary; and, after the excitement, the hurry, and the excrtion of the previous day, the quiet of the hour fell upon me like a happy dream; and I remember that I shed tears as I lay back upon my cushions, and looked upwards to the calm moon, and listened to the thrilling melody of the midnight woods, and felt the soft wind fanning the hair upon my brow; but they were tears in which there was no bitterness; an outpouring of the wearied spirit that relieved its weight; and when we 
once more became entangled in the floating crowd, and dashed forward into the blinding light of the fire-girt Palaces, the heart-laugh which went ringing over the ripple might sometimes have been traced to me.

The mere worldling will sneer at this admission; but those whose misfortune it is to feel deeply will understand the seeming inconsistency.

The sixth day was fixed upon for the Ambassadorial Banquet, where the representatives of the Mighty Ones of the Earth were to feast together at the board of the Brother of the Sun, and Emperor of the World. A table, wellappointed in the European style, had been prepared; and the banquetting tent was neatly fitted up with draperies and mirrors.

In the evening a new and distinct feature was added to the entertainments, by the introduction in the outer court of the Palace of a raised platform, on which a score of performers, clad in half armour, attempted a species of wardance to the light of a dozen bonfires, which flashed and faded by turns; now revealing the glittering costume of the struggling and strag. gling combatants, and now enveloping them in a cloud of dense black smoke, as impenetrable as the waves of Erebus. The whole thing was a failure; and the only charm attendant on the exhibition, was the singular transition of light 
and shade that played over the surface of the painted palace, and which produced effects almost magical; now touching the lofty portal with a golden gleam, and then fading away into a faint green, caught from the leafy boughs which fed the fires.

The Turks are decidedly not a dancing nation. 


\section{CHAPTER XXVIII.}

Monotonous Entertainments - Bridal Preparations - Common Interest -Appearance of the Surrounding Country - Ride to ArnautkeuiSight-loving Ladies-Glances and Greetings-Pictorial Grouping The Procession-The Trousseau-A Steeple-Chase.

Thus far all had been monotonous from its constant repetition; the same dramas had been enacted, the same lamps had been lighted, and the same banquets had been prepared: but the seventh day was the eve of the Imperial marriage, on which the trousseau of the bride was to be borne in state from the Palace of Dolma Batchè, to her own glittering Seraï on the Bosphorus. The period was arrived when her slaves, on withdrawing her from the bath, were to braid her long tresses with threads of gold, and strings of pearl, and to stain the palms of her hands and the soles of her feet with henna.

At an early hour the streets of Pera were crowded with arabas and saddle-horses; and my own eager little chesnut was neighing out his impatience under my window before eight 
o'clock. It was a glorious morning, bright and sunny, without a cloud; and, as I sprang into my saddle, I felt that this was a day on which the Fates had resolved to weave a white thread into the web of my existence.

All the three hundred thousand persons said to have been collected in Constantinople on the occasion of the Imperial marriage, must have been beside our path that morning! I never before beheld such a gathering of human beings. There had been divided interests during the previous days of festival: different points of attraction, which had wrenched asunder the mighty mass of mortality, and fashioned it into divers portions; but on the present occasion, men's minds were all bent upon one object; and this community of purpose had collected them together in one vast multitude.

The road was guarded by armed sentinels; and about an arrow's flight from the Military College, on the line from Dolma Batche to the Palace of the Princess, a handsome tent had been pitched for the Ambassadors, which was already thronged. Every rising ground was occupied as far as the eye could reach; and the outline of the road along which the procession was to pass, was marked by clusters of females, seated so closely together that from a short distance they appeared to form one compact body. Behind these were ranged lines of arabas, filled 
with Turkish, Greek, and Armenian ladies; while on the open space beyond, horsemen galloped to and fro; pedestrians, who had been too tardy to secure advantageous places, straggled from spot to spot, in the hope of establishing themselves among some knot of friends; and water-venders, with their long-necked earthen jars and crystal goblets, passed from one party to another, disposing, at an usurious interest, of their tempting merchandize.

As there was no sign of the procession when we reached the Ambassadorial tent, we resolved to canter on to Arnautkeui, and amuse ourselves by a survey of the way-side groups ; and a most interesting ride it was. As the Turkish women generally, on any occasion which takes them from their homes at an early hour, profit by the circumstance to remain in the open air all day, none of our party were surprised at the well-organized arrangements that were making on all sides. The whole line of road from Dolma Batchè to the kiosk above the Palace of Arnautkeui was edged with specta. tors; and wherever a tree afforded the means of doing so, shawls and rugs had been stretched against the sun, producing a very cheerful and pretty effect. The number of Turkish females collected together on this occasion may be imagined when I state that a friend of mine, on whose veracity I have the most perfect re- 
liance, assured me that he knew it to be a fact, that several of these sight-loving ladies had actually sold the tiles off the roofs of their houses, in order to raise money enough to enable them to hire an araba for the last two days of the Festival!

Nor was this all; for a still more startling fact came to my knowledge from so authentic a source that I state it without hesitation. A Turkish female in a respectable station of society, having in vain importuned her husband for the means of witnessing the festivities in a manner suited to her rank, and receiving for an answer the assurance that he was unable to comply with her request; finding that she had no hope of success save through her own ingenuity, set herself to work to devise some expedient by which she might raise the necessary sum; and having taken into her confidence a favourite slave who was to accompany her in the event of any fortunate discovery, it was at length decided between them that she should sell her son, a fine little boy of about five years of age. No sooner said than done; she adjusted her yashmac and feridjhe, took her child by the hand, and, followed by her attendant, proceeded to the house of a slave merchant, where the bargain was soon made, and the sum of three thousand piastres given in exchange for the little Musselmaun! 
The astonishment of the husband may be conceived, when on the morrow he saw his wife seated in an araba in the midst of a bevy of her fair friends, without being able to discover how she had contrived to secure a carriage at so expensive a period. He demanded an explanation in vain; and it was not until he inquired for his child, and detected a mysterious confusion in the manner of his wife, that a suspicion of the fact flashed upon him. He insisted on hearing the truth; and when he at length learnt it, he hurried like a madman to the slave-merchant, and demanded back his boy; but the dealer in human beings had no expensive sympathies; and he only answered the agonized intreaties of the father, by asserting his willingness to deliver up the child when the money which he had given for him was repaid. The wretched parent had it not to give; and finding that his misery produced no effect upon the slave-merchant, he hurried in his anguish to the Seraskicr, who, having heard the tale, summoned to his presence the mother, the child, and the merchant; and after having ascertained that the fact was precisely as it had been stated to him, he expressed to the former his horror of the unnatural deed of which she had been guilty, and received for answer that she had acted under the firm conviction that her husband had merely refused to supply her with money from an impulse of 
avarice; and that, being devoted to his child, he would immediately purchase him back. The apology, poor as it was, was admitted; and the Seraskier, finding that the father really did not possess the means of recovering his boy, generously paid the price of his liberty, and restored him to his parents; only cautioning the mother not to attempt a second sale of the same description, as, in the event of such an occurrence, she should herself be her child's ransom.

Hear this, ye Englishwomen, who have been accustomed to believe that the Turkish females are always under lock and key-Hear this : and then imagine to what a pitch they carry their love of dissipation and expense.

Not the least amusing part of the ride was the multitude of recognitions and salutations consequent upon our progress through the crowd. Here a veiled lady greeted us from her gilded araba; and there a laughing Greek saluted us from beneath his wayside tent. On one side, we were joined by a rival party of mounted Franks ; and on the other we were beckoned aside by some pretty friend, who was seated under the shade of a cluster of overhanging branches.

Had there been nothing further to anticipate, the mere sight of the great congregation of human beings collected together that morning, would of itself have been a highly interesting. spectacle. 
Probably in no other country upon earth can you encounter such groups as you do in Turkey; they always appear as though they had been arranged by an artist; and I find myself on every occasion just about to describe them, when I remember that I have already done so more than once; and am compelled, however reluctantly, to forego the inclination.

Having reached the crest of the hill above Arnautkeui, we turned our horses' heads once more towards Dolma Batchè; and had almost reached the Palace when the sound of a military band came cheerfully on the wind, and we were obliged to gallop off, in order to secure an elevated station whence we could conveniently witness the passage of the procession.

We were fortunate enough to possess ourselves of a spot of ground that overhung the road, along which we reined up our horses in line, and awaited the arrival of the pageant.

The Band led the way, playing the Sultan's Grand March upon their wind instruments, and the military followed in good order; it was a squadron of the élite of the Turkish Army, the Cavalry of the Imperial Guard, whose several troops are distinguished by the different colour of their horses. I counted four negro officers as they passed us.

The Troops were succeeded by fifty Field Officers, the General Staff of the Empire, well 
mounted and attended; and they, in their turn, gave place to twenty Great Officers of the Imperial Household. With these individuals commenced the interest and Orientalism of the spectacle; the flashing diamonds upon their breasts and hands, and the glittering housings of their horses, relieving the monotonous slowness with which they progressed. This splendid train was followed by fourteen led mules, laden with packages, covered with the gold and silver stuffs of Broussa, and secured upon the animals with cords of silk. The packages contained the velvet and satin mattresses intended for the harem of the Princess, and all the minor articles necessary to her household; which are supplied by the Sultan, even to the feather-brush that beats aside the flies from the dinner-table.

Next came twelve beautiful white mules, magnificently housed, and led by pages dressed in a scarlet uniform : a present to the Princess from her Imperial Father.

Nine carriages of silver net-work, roofed and draperied with coloured silk, each drawn by four bay horses, followed next in line; and through the transparent lattices glittered the costly sofafurniture of tissue and embroidery; the velvet cushions, and the golden fringes which were to adorn the saloons of the bridal Palace.

After these came three open droskys, with pages running at the bridle-rein of the superb 
leaders, who seemed impatient of the pace at which they travelled, and scattered the foam from their mouths as they champed their embossed bits; and these were overlaid with cloths of crimson velvet fringed with gold, on which was displayed a collection of richly-chased silver plate.

Then followed five other carriages, drawn like the foregoing by four stately horses, containing trunks covered with coloured velvets and gold and silver stuffs, and clamped and hinged with wrought silver, laden with the linen of the Imperial Bride.

Next came forward what, at the first glance, seen as it was through the cloud of dust raised by the carriages, seemed to be a moving tulipbed, extending far as the eye could reach. Nor was the illusion an overstrained one; for this portion of the procession proved to be a train of one hundred and fifty men, each attended by a page, and bearing upon his head a basket of wicker-work, covered with gold tissue, and surmounted by a raised dome of coloured gauze, decorated with bunches of artificial flowers. Beneath these transparent screens might be seen the toilette of the young Princess; her golden ewers, and jewel-studded basins-her diamondcovered essence-boxes, and gemmed water-vases -her glittering porcelain, her emerald-mounted hair-brushes-and all the costly gauds which litter so magnificently the chambers of the 
great. Golden cages, filled with stuffed birdsinlaid caskets, heavy with perfumes - musical instruments, rich with laboured gold and jewels - salvers, up-heaped with gold coins-and ten thousand brilliant toys, if not without a name, yet almost without a use, followed in their turn ; and then came pyramids of sweetmeats, glittering like fruits which had suddenly been hardened into gems; and trays of shawls, each one a fortune in itself, enveloped separately in wrappers of coloured gauze, tied with long loops of ribbon.

But the most gorgeous display was yet to come; embroidered handkerchiefs whose gold and silver threads were mingled with silks of many hues, and whose texture was almost as impalpable as the gossamer - jackets of velvet worked on the sleeves and breasts with precious stones-trowsers sprinkled with stars of gold and silver - anteries of white silk, wrought with coloured jewels - robes of satin powdered with seed-pearl-slippers as diminutive as that of Cinderella, fringed with floss silk, and powdered with rubies; and finally, sixteen bearers, balancing upon their heads cages of silver wire, resting on cushions of crimson velvet, whereon were displayed the bridal diamonds. The sunshine was flashing on them as they passed us, and at times it was inpossible to look upon them.

VOL. I. 
It seemed as though the trees of the Serai must have dropped diamonds, to supply the profusion of the Imperial Father. It is impossible to describe them - the diadems and bracelets, the necklaces and wreaths, the rings and clasps: suffice it that every female article of dress or ornament, for which this costly stone could be made available, was here in its magnificence; and assuredly the gifts of the Queen of Sheba to King Solomon must have sunk into insignificance before the bridal trousseau of the Princess Mihirmàh-“"The Glory of the Moon!"

Forty mounted negroes appointed, to her household followed, like demons of darkness, on the footsteps of the flashing treasure which I have just described; and I can safely declare that I never beheld so hideous an assemblage of human beings. The diamonds were quite secure, I should imagine, from all depredators, under the charge of these frightful guardiansthese gnomes, gloating over the produce of the "dark gold mines," where no light could intrude in which they might mirror their own ugliness ; and His Sublime Highness, or rather his Master of the Ceremonies, appeared to have been of the same opinion; for although a guard preceded the procession, none followed it; and the termination of the pageant came so abruptly upon me after its greatest splendour, that I felt as though some accident had detained the re- 
maining actors in the show, and that something more must follow; but as, after the lapse of a moment, I discovered that all was really over, there was nothing for it but a steeple chase " over bank, bush, and briar," in order to get once more in advance of the procession, and thus secure a second view.

On this we accordingly determined; and after a gallop over ploughed fields, and a few leaps over sundry intervening fences and ditches, we found ourselves on the height above Arnautkeui, just as the gorgeous train was beginning to descend the hill. 


\section{CHAPTER XXIX.}

The Bridal Day-Ceremony of Acceptance-The Crowd-The Kislar Agha and the Court Astrologer - Order of the Procession - The Russian Coach - The Pasha and the Attachés-The SeraskierWives of the Pashas-The Sultan and the Georgian Slave.

The morrow was the bridal day, when the fortunate Saïd Pasha was to receive his Imperial Bride beneath his own roof, and to look upon her for the first time. As yet he had not had even a glimpse of her through her yashmac, their only interview having taken place on his arrival from the Dardanelles, when he had been summoned to the palace to throw himself at her feet, and to return thanks for the honour she was about to confer upon him. This interview, if such indeed a meeting may be termed in which one of the parties only has a sight of the other, is one of the ceremonies à la rigeur in the Imperial marriages of the East.

The bridegroom elect is led into a room, at whose upper extremity a door stands ajar; and behind this sits the lady splendidly habited, and surrounded by a train of slaves. $\Lambda$ small portion of her embroidered antery is suffered 
to pass the opening of the door; and a side lattice, veiled with thin gauze, enables her to take a view of her suitor as he approaches; which he does slowly, and upon his knees, the whole length of the apartment. On arriving near the "Door of Light" that conceals the Princess, he thrice bows his forehead to the earth, ere he ventures to implore a ratification of his hopes. The officious Kislar Agha replies for the bride; and after a second prostration, the Pasha returns thanks " in a neat speech;" and with the permission of the same personage, he then raises to his lips the hem of the Imperial garment, and retires in the same humble posture in which he entered.

The on dit at the Palace whispered the disappointment of the bride on the present occasion, that the choice of her Imperial father had not fallen on Mustapha Pasha of Adrianople, whom she had once seen by accident, and by whose personal beauty she had been much attracted. It is, nerertheless, possible that this glimpse of her destined bridegroom reconciled her to her destiny; for, as it is the appearance only to which Turkish females generally attach any importance in their husbands, the young Pasha of the Dardanelles could safely compece with all his rivals, being really a very handsome and intelligentlooking person.

Had I not known that such a thing was alto- 
gether impossible, I should have said, when I pulled up my parting horse on the height above the palace, that the same groups occupied the same spots where I had seen them on the previous day. The scene did not appear to have altered in a single feature. I saw the same smiling faces, and received the same kindly greetings ; laughed at the same dirty, stupid-looking sentinels, and bought a cool draught from the same water-vender for a twenty para piece; and, altogether, I had some difficulty in persuading myself that I had really talked politics with a hot-headed Englishman, theology with a Greek Papas, and nonsense with a Sardinian Secretary, and moreover had slept through a long night, since I last stood upon that sunny hill, and looked far and wide upon the same wilderness of human beings.

The procession of the preceding day had bcen announced to start from Dolma Batchè at eight o'clock, but the mid-day muezzin had been called from the minarets, ere the first trumpeter issued from the portal. Profiting, therefore, by our experience, we partook of a quiet breakfast on the present occasion, ere we sped to the scene of action; and we had judged rightly in so doing, for we were yet considerably in advance of the bridal train. Nevertheless, it is certain that the baggage-mules and the treasure-carriages required more time to prepare them for the jour- 
THE KISLAR AGHA AND THE ASTROLOGER. 503

ney than the Imperial Bride, and her attendant train of ladies ; for the Kislar Agha was yet girding on his sword with all the quiet precision of a man who has no cause for haste, when a negro of the Seraï rushed into the apartment, and startled him with the intelligence that her Highness was not only ready to start, but actually in the Great Saloon of the Harem, waiting for him to precede her to her carriage. At this announcement the portly personage suffered his weapon to fall from his hands ; and tossing. his arms above his head, he filled the apartment with his outcries.

"Who has done this? Who has insidiously counselled this haste? Where is the traitor who would destroy the Imperial Daughter of our noble Sultan? (May his beard be white!) It yet wants ten minutes of the time appointed by the astrologer - the lucky moment is not come-and until it arrives, she shall not set her foot without the palace, were it ten times her bridal day."

At length, however, the auspicious moment really did arrive, when the Kislar Agha was himself the first to hasten the departure of the Princess. 'The procession was the very triumph of mystery. All the high-born beauties of Stamboul were to pass us by, and we were only to imagine the loveliness on which we were to have no opportunity of looking. 'The Sultan's Band opened 
the march, and executed with great precision a piece of martial music, composed for the occasion by their talented leader Donizetti; a regiment of cavalry followed, and was succeeded in its turn by agorgeous train of Pashas, among whom rode the bridegroom; and then came the European carriage of the Sultan, drawn by four bay horses, each led by a page in a scarlet and gold uniform. This was succeeded by the Imperial State Coach, of silver gilt, the raised cornice above the roof inlaid with cornelians, agates, and jaspers, the magnificent gift of the Emperor of Russia to his Turkish ally-the gilded lattices, through which gleamed the jealous curtains of rose-coloured silk, were closely shut; and the Imperial Bride was the sole tenant of the costly vehicle. This carriage, which was drawn by six stately horses from the personal stud of the Autocrat, was followed by that in which the Princess had been accustomed to drive on state occasions; the windows were thrown back, and the curtains undrawn-it was empty. Next came the Sultana-Mother, the Princess Salihè, and the younger sister of the bride, a sweet-looking girl of eleven or twelve years of age, who sat beside her veiled relatives in a heavy head-dress of black velvet, overcharged with diamonds; but whose fair young face laughed out in loveliness beneath the hideous disfigurement. These were succeeded 
by a second Russian carriage, drawn by four horses similar to those in the State Coach, an offering of Russian policy to Achmet Pasha, whose Buyuk Hanoum was within, attended by three female slaves.

The train amounted in all to forty-seven carriages and four; many of them tenanted by five and even six individuals, whose coquettishly arranged yashmacs afforded at times something more than a glimpse of their fair faces; a fact of which the negro guard appeared so well aware, that on some suggestion from one of them to a Pasha, who rode immediately in front of the Imperial carriage, on the second apparition of our party by the way-side, (which, soit dit en passant, must have been sufficiently attractive to the veiled beauties, being principally composed of attachés to the different embassies), His Excellency addressed himself to me in very tolerable French, and told me that, although I was individually at liberty to accompany the procession to the Palace-gates if I wished to do so, he must request that the gentlemen would not attempt to advance further. But the prohibition was more readily uttered than obeyed; and we only just waited for a first glimpse of the fifty negroes who formed the rear-guard, ere we were off again, as fast as our generous horses would carry us.

And well should we have been repaid when we 
pulled up midway of the steep descent leading to the Palace, had it only been by the spectacle of the wily old Seraskier, who rode beside the window of the State Coach, in a state of admirably got-up agitation; first shouting to the troop of attendants who hung on to the wheels, like a man in the last agony ; and then modulating his voice to the extremest gentleness of which it was susceptible, to implore of the Imperial Bride not to imagine that there existed the slightest danger; half the fuss that he was making meanwhile, being more than sufficient to satisfy her that she was on the eve of being hurled over the precipice.

On her arrival in the Court of the Palace, Said Pasha, on his knees beside the carriage, received her in his arms, and carried her into the Great Saloon of the Harem; the ladies of the Court, who had the entrée, followed in succession; the golden gates were closed: and the excluded had nothing more to do than to shake the dust from their garments-and truly it was about an inch thick-to swallow a glass of iced lemonade in the saddle, and to gallop back, under a burning sun, to their respective homes.

Each Pasha, on the occasion of an Imperial marriage, sends on a stated day his Buyuk Hanoum, or principal wife, to the Palace, attended by two slaves, to congratulate the Princess on her approaching nuptials; and 
these are the ladies who subsequently form the reception circle at her new home. At the visit of felicitation, when the Sultan receives them on the part of his august daughter, they are presented by the munificent sovereign with an antery, jacket, and trowsers of rich stuff, a pair of embroidered slippers, and a diamond ring; the same articles, but fitted in value to their station, being bestowed also on their attendants. In this magnificent costume they are expected to appear on the bridal day; and on their departure from the Presence, they place their own gifts in the hands of the Kislar Agha, which are always of the extremest richness that the means of the Pasha will permit.

An amusing anecdote is connected. with this ceremony, which, being authentic, I may as well relate. The Imperial Presentation negatives the necessity of yashmacs, and thus Sultan Mahmoud enjoys the exclusive privilege of forming a judgment on the taste of his Pashas. On the marriage of the Princess Salihè, the Reiss Effendi forwarded to the Imperial Presence the mother of his sons, a lady to whom nature had not originally been lavish of her gifts, and who had subsequently lost an eye during an attack of plague. His Sublime Highness was observed to fidget upon his sofa as the presentation took place, but the Buyuk Hanoum was received with all the honours due to the exalted rank of her 
husband, and departed laden with the rich gifts of Imperial generosity.

On the morrow, however, a caique impelled by three rowers, and freighted with a closely veiled female under the guard of a party of the negroes of the Serai, pushed off from the $\mathrm{Pa}$ lace of Dolma Batchè, and ran alongside the terrace of that of the minister; when the lady was landed, and, on being conducted into the presence of the Reiss Effendi, her veil was withdrawn, and she proved to be a lovely Georgian slave of about sixteen years of age, in all the first burst of her young beauty - a present to the noble from his Imperial Master, accompanied by a command, that should another occasion occur in which the wives of the Pashas were required to appear before the Sultan, the Reiss Effendi would cause the dark-eyed Georgian to act as the representative of a lady, whose age and infirmities must render all court ceremonials extremely irksome to her feelings.

Of course, the lovely slave was one of the bridal train of the Princess Mihirmàh! 


\section{CHAPTER NXX.}

A Ner Rejoicing - Shohastic Processious - Change in the Valley The Odalique s Grave - The Palace of Eyoub - The State Apartments-Return to Pera.

A couple of days of rest succeeded to the marriage festivities, and during that time all the tents which had fringed the height above Dolma Batche were transferred to the Valley of the Sweet Waters, whither they were followed by the tumblers, rope-dancers, and jugglers, who had delighted the crowd in the purlieus of the Imperial Palace. A new rejoicing was to succeed the bridal feites; the two younger sons of the Sultan, and eight thousand children. belonging to every class of the 'Turkish population, from the Pashas to the charcoal-venders of the metropolis and its vicinity. were to be circumcised with much pomp at hishaitchana. A temporary building; shaped like a crescent. and capable of containing the whole number, had been erected above the upper kiosk, and near the border of the stream. across which a new bridge had been thrown; the pavilion was 
lined throughout with rich hangings, and well cushioned, and presented a very gay and pretty appearance.

'The Sultan entertained the Imperial Family at his Palace on the Barbyses ; the Pashas gave daily dinners in their tents; and there was not an araba in Constantinople or Pera that was not in requisition.

After passing to Eyoub in our caïque, we hired a close araba, in which we drove to the valley. The scene was a very animated one; lines of coffee-tents clung to the sides of the heights; groups of women, seated on their mats, were scattered over the greensward; itinerant fruitmerchants wandered to and fro, with their strawberries neatly arranged in small baskets wreathed with oak leaves, and their cherries heaped in pyramids; mohalibè and yahourt were to be seen on all sides : the little fountains of the sherbet-venders were tinkling like distant sheep-bells; and, high above the heads of the crowd, a rope-dancer was balancing himself in mid-air, with his crimson satin vestment flaring in the hot sunshine.

One pretty feature in the scene was the constant succession of scholastic processions; each mosque sending its little troop, headed by an Imam, to parade the valley, and to chant a prayer for the preservation of the Sultan's sons ; after which all the children of the Turkish, Greek, 
Armenian, Catholic, and Jewish schools, accompanied by their masters, passed before the Sultan, and shared in the festivities, to which they had been especially invited." Nor was the ap: pearance of the 'Turkish children who assisted at the ceremony less interesting; as they all, save those belonging to the more distinguished families, who wore a vast quantity of gold embroidery about their coats and fèzes, were dressed in a kind of uniform, provided for them by the Sultan ; and had their long hair plaited in innumerable braids, and woven together with gold threads, sometimes to a quarter of a yard in breadth.

For the first hour I was exceedingly amused. The Barbyses was alive with caïques - the air was loud with music and laughter - the greensward was crowded with arabas and idlers; and every shady tree had a colony beneath its boughs. But I soon wearied of the coil and confusion by which I was surrounded; the green, fresh, quiet valley had lost all its charm ; I could scarcely recognize my favourite spots; nor was it until the close of twilight, when the illuminated glories of the port flashed out like a circle of fire in the distance, that I became reconciled. The moon silvered over the rippling river; the nightingales were loud in the Palace gardens; a million of twinkling stars were relieving the deep blue of the summer sky; while 
here and there erections of many-coloured light rose flashing out amid the leafy boughs of the crowd-invaded glen. Pashas came and went in their noiseless caïques; dulcimers and tambourines deadened at times the music of the night bird ; and the low wind, which heaved the elastic branches of the water willow, and came sighing along the ripple of the sweet river, rendered the valley by night a scene of enchantment.

I wandered to the grave of the Odalique : the moonlight was resting upon the record-stone; and a nightingale, seated amid the branches of the overhanging tree, was breathing out its song of mournful melody : it was far away from the idle throng of revellers, and I was weak enough to be glad that it was so.

The night was so lovely that we dismissed our araba, and determined on returning in a caïque as far as the Palace of Eyoub, where I had been invited by the Princess Azmè to pass the night; but, on arriving there, we found that the Sultana and the principal ladies of her household had been detained by the Sultan, and would not return until the following day.

As, however, I was fearful that the opportunity of seeing this palace might not recur, from the fact that the Princess never inhabits it save on occasions of festival at Kahaitchana, when she profits by its vicinity to the valley, I availed 
myself of the offer of the house-steward to show me over the state apartments, which are entirely unfurnished, but in themselves extremely magnificent. The screen, of light that extended along the whole front of the building cast its glare through the unshuttered windows, and was reflected back by the gilded walls and glittering cornices. The decorations throughout are heavy, but of the greatest richness, and by far the most Oriental in their character, of any that $I$ had yet seen. The palace was built by Sultan Selim, and its situation is beautiful. What was formerly the reception-room of that unfortunate Sovereign, is entirely lined with gilding, the walls being niched, and overhung with stalactited cornices similar to those which decorate many of our old cathedral tombs; and the weight of this elaborate ornament is relieved by a ceiling of faint blue, sprinkled with silver stars. But the absence of furniture, and the vast extent of the building, gave an air of desolation and discomfort to its whole appearance, which even the well-matted and curtained rooms that had been temporarily fitted-up for the use of the Sultana's harem failed to overcome : and, consequently, when I had satisfied my curiosity, I pleaded the absence of Her Highness, and those individuals of her suite with whom $I$ was acquainted, as my apology for not availing myself of her flattering invitation; and, reVOL. I.

L L 
entering our caïque, we dashed out into the centre of the port; and after contemplating for a time its temporary glories, were landed at the Echelle des Morts, and, passing along beneath the moon-touched and sighing cypresses of the grave-yard, soon found ourselves at Pera.

END OF YOL I. 



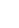

-

, 

University of California

SOUTHERN REGIONAL LIBRARY FACILITY 405 Hilgard Avenue, Los Angeles, CA 90024-1388

Return this material to the library from which it was borrowed.

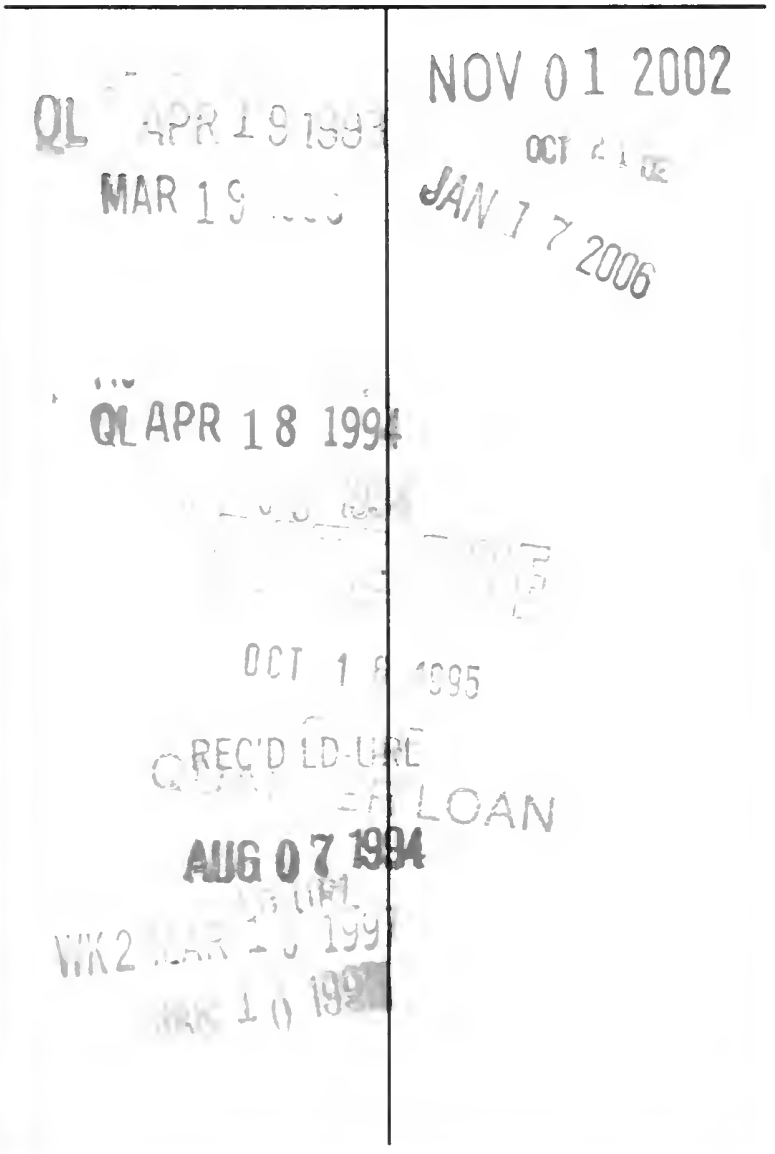


$\||\||\||\||\||||||||||||||||||$ 


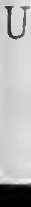

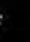

. 